\title{
Adipose mesenchymal stromal cells to minimize and repair radiation-induced oral mucositis
}

\author{
Osama Mohamed Maria \\ Experimental Medicine Department \\ Faculty of Medicine \\ McGill University \\ Montreal \\ Quebec \\ Canada
}

December 2015

\begin{abstract}
A thesis submitted to
McGill University

In partial fulfillment of the requirements of the degree of

Philosophy of Doctorate
\end{abstract}

(C) Osama Mohamed Maria 2015 
This page is intentionally left blank 


\section{TABLE OF CONTENTS}

TABLE OF CONTENTS .................................................................

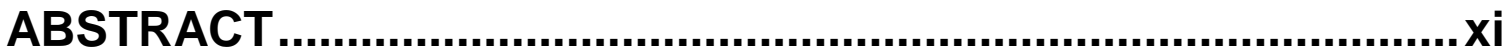

RESUME Xii

AKNOWLEDGEMENTS ..................................................................

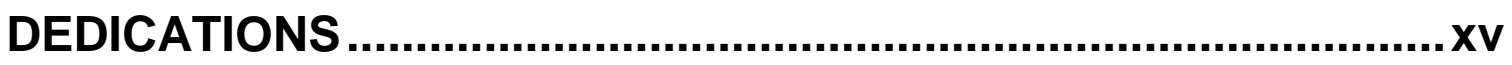

PREFACE AND CONTRIBUTIONS OF THE AUTHORS ................. xvi

Chapter 1 INTRODUCTION .....................................................1

1.1 RADIATION-INDUCED ORAL MUCOSITIS (RIOM) …........................... 1

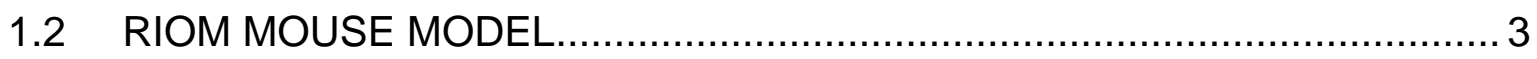

1.3 MESENCHYMAL STROMAL/STEM CELLS THERAPY ............................ 4

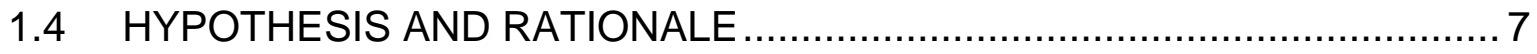

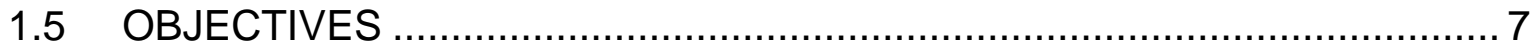

Figure.1.5.1: The therapeutic index with respect to cumulative dose [112] ........................... 8

Figure.1.5.2: Stem cells translational research steps from bench to bedside $[113,114] \ldots \ldots . . .9$

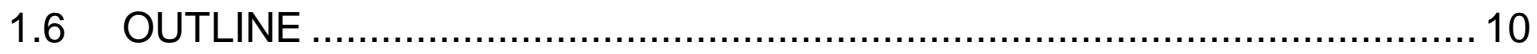

Chapter 2 REVIEW OF RADIATION-INDUCED ORAL

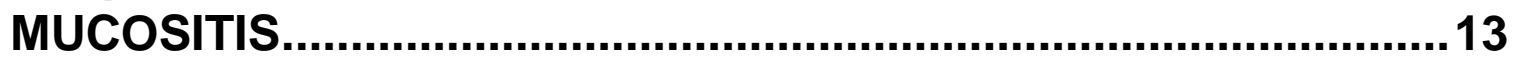

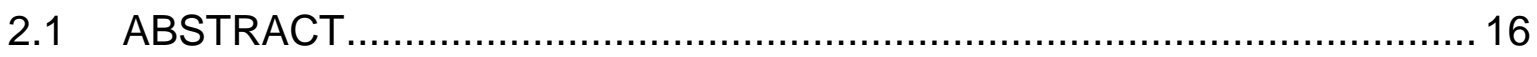

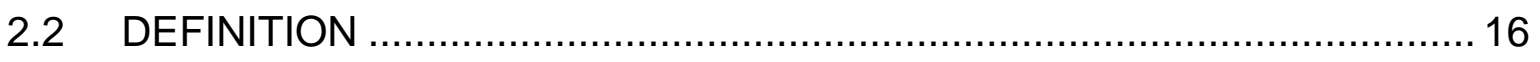

Figure.2.2.1: Grade III RIOM on WHO scale ............................................................ 17

Figure.2.2.2: RIOM duration, onset, and resolution [115] ................................................ 18

Figure.2.2.3: WHO's grade III-IV RIOM showing mucosal ulcer, hyperemia, and wide spread epithelial sloughing.

2.3 RIOM EPIDEMIOLOGY (INCIDENCE, PREDICTORS, AND RISK FACTORS)

Table.2.3.1: Data analysis for RIOM predictors using IBM SPSS version 21.0 (Armonk, NY, USA)

Table.2.3.2: Patient-linked factors leading to increased risk for OM [125] 


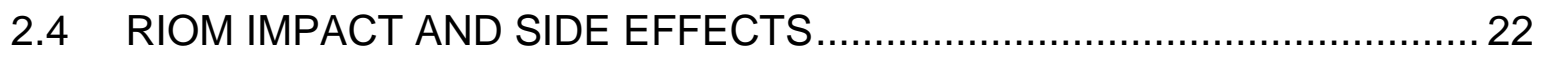

2.5 PATHOGENESIS AND SUGGESTED MECHANISTIC PATHWAYS ......... 22

Table.2.5.1: Signaling Pathways Involved in the Development of Mucositis [129] .................24

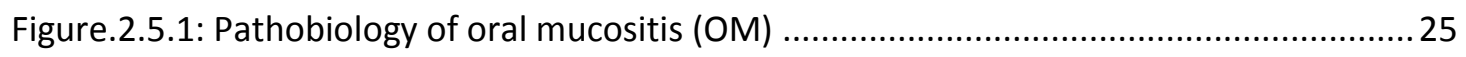

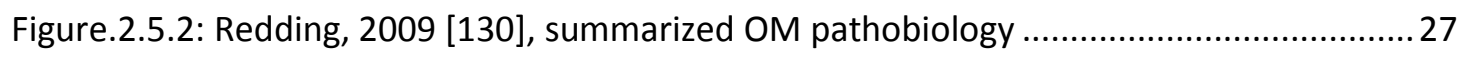

Figure.2.5.3: Signal amplification during OM from both RT and CT [129] .............................29

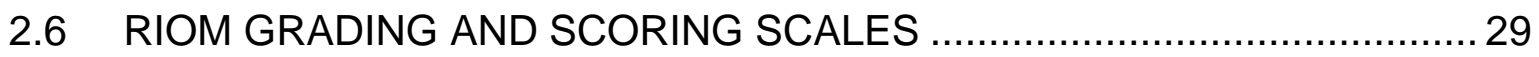

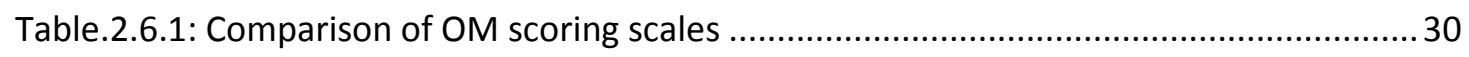

Figure.2.6.1: World Health Organization's Oral Toxicity Scale.............................................. 32

2.7 DIAGNOSIS OF RIOM.................................................................. 33

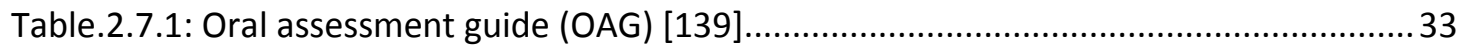

2.8 DIFFERENTIAL DIAGNOSIS OF RIOM ........................................... 33

Table.2.8.1: Differential diagnosis of RIOM [3, 44]. BMT = Bone Marrow transplantation..... 34

Figure.2.8.1: Differential diagnosis of RIOM from similar and/or accompanying conditions.. 35

2.9 PROGNOSIS OF RIOM .............................................................. 35

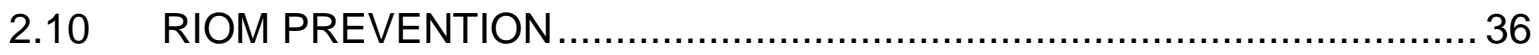

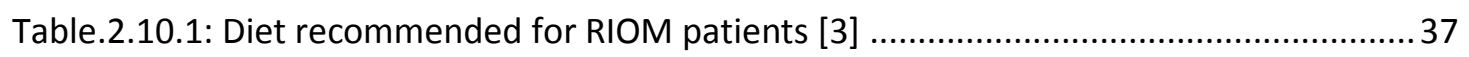

Table.2.10.2 Multinational Association for Supportive Care in Cancer/International Society

for Oral Oncology (MASCC/ISOO) Clinical Practice Guidelines for Oral Mucositis [115] ......... 40

2.11 RIOM TREATMENT ............................................................... 40

2.12 CELLULAR THERAPIES FOR RIOM ............................................. 43

2.12.1 Clinical trial for RIOM ......................................................... 44

Table.2.12.1.1: RIOM the clinical trials that have been done until 2001 [4]........................... 48

Table.2.12.1.2: Clinical trials for RIOM as listed on www.ClinicalTrials.gov when searched in

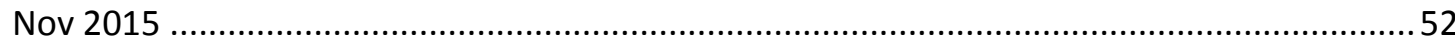

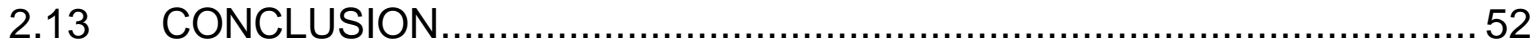

Chapter 3 REVIEW ON MESENCHYMAL STROMAL CELLS THERAPY IN RADIATION ONCOLOGY REGENERATIVE MEDICINE................................................................56

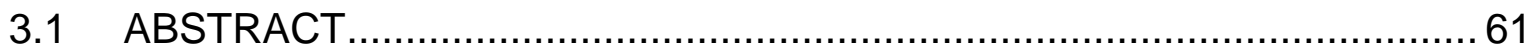

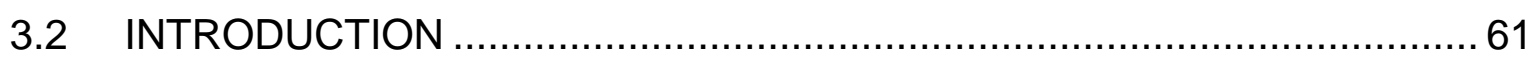

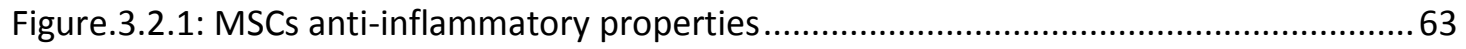


3.3 MESENCHYMAL STROMAL CELLS (MSCs) CLINICAL TRIALS IN VARIOUS DISORDERS

Table.3.3.1 Mesenchymal Stromal cells (MSCs) clinical trials in various disorders as listed on

www.ClinicalTrials.gov by the National Institute of Health (NIH) by Nov. 2015

3.4 MESENCHYMAL STROMAL CELLS (MSCs) RADIO-BIOLOGICAL

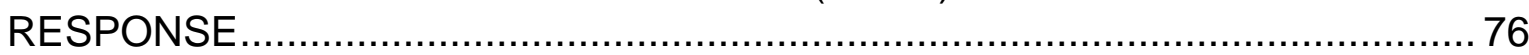

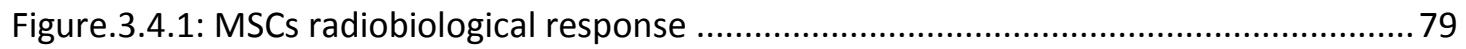

\subsection{MSCS APPLICATIONS IN RADIATION ONCOLOGY REGENERATIVE}

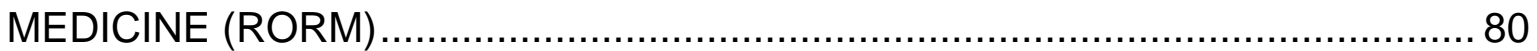

3.5.1 Skin repair application after radiation exposure …........................... 80

3.5.2 Intestinal repair application after radiation exposure ........................ 81

3.5.3 Lung tissue repair application after radiation exposure ….................. 82

3.5.4 Hematopoietic system homeostasis radiation injury........................... 82

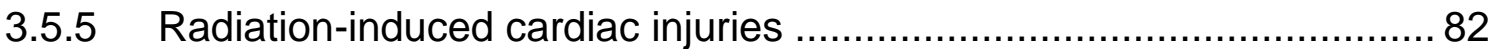

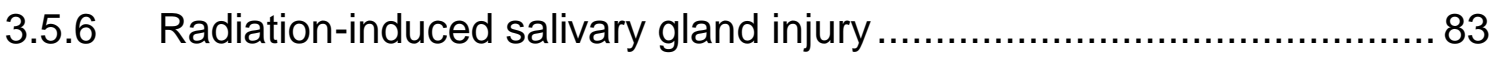

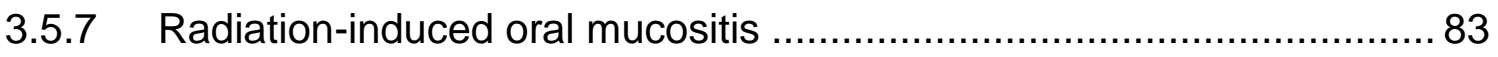

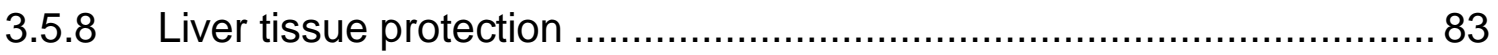

3.5.9 Studies with gene-modified MSCs for RORM ................................. 84

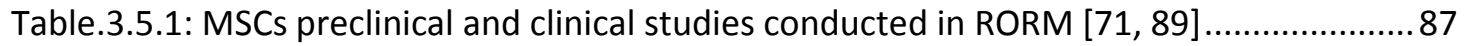

3.6 ADIPOSE TISSUE-DERIVED MSCS (AMSCS) …............................. 87

Table.3.6.1: Adipose Mesenchymal stromal cells (aMSCs) clinical trials

(www.ClinicalTrials.gov) by the National Institute of Health conducted in RORM ...................92

3.7 MSCS MECHANISM OF ACTION IN RORM .......................................... 92

3.8 CHALLENGES FACING MSCS THERAPY .......................................... 92

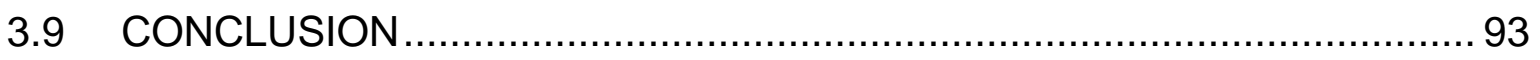

Chapter 4 ADIPOSE MESENCHYMAL STROMAL CELLS RESPONSE TO IONIZING RADIATION .......................................97

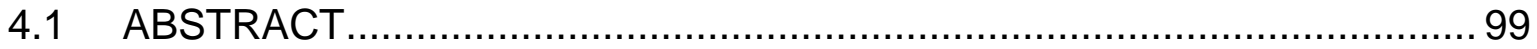

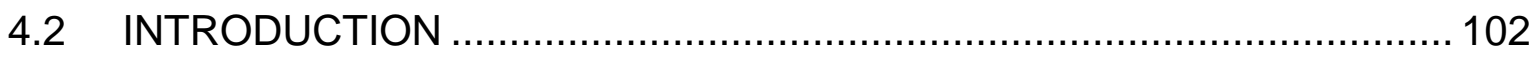

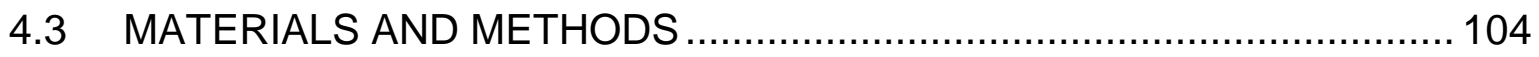

4.3.1 Isolation of mouse adipose tissue-derived MSCs (aMSCs) ............... 104

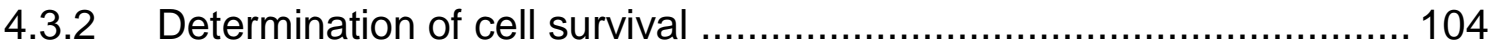

4.3.3 aMSCs functional differentiation assays........................................ 105 
4.3.4 Immunohistochemistry (IHC) staining........................................... 105

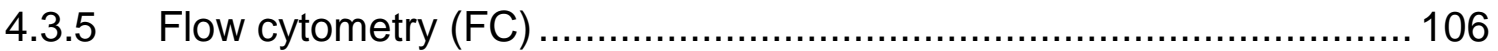

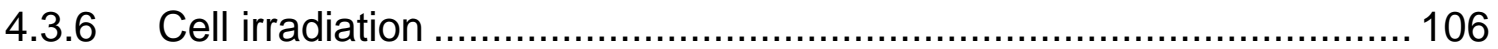

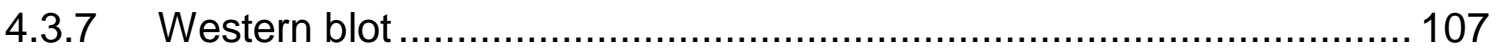

4.3.8 dsDNA breaks assay (Gamma H2AX, $\gamma-\mathrm{H} 2 \mathrm{AX}$ ) .............................. 108

4.3.9 Single stranded DNA (ssDNA) breaks (SSBs) assay (Comet assay). 108

4.3.10 Apoptosis assay (Annexine-V) .................................................... 109

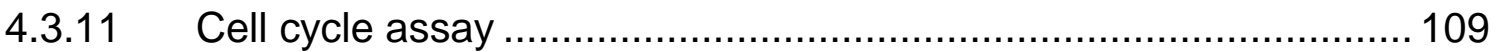

4.3.12 $\mathrm{RT}^{2}$ profiler PCR array ....................................................... 110

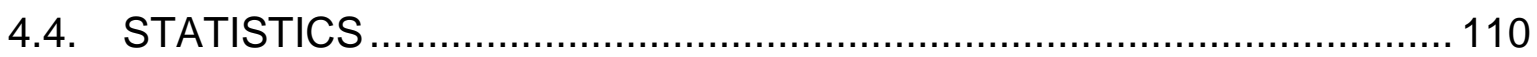

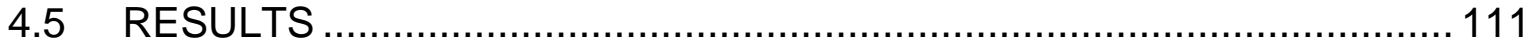

4.5.1 Irradiated aMSCs maintained their stem cells functionality and

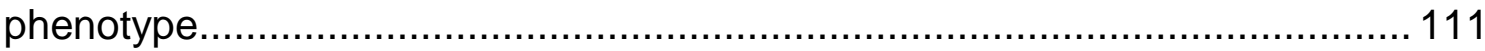

Figure.4.5.1.I: aMSCs multi-lineage differentiation after ionizing radiation..........................113

Figure.4.5.1.II: Flow cytometry (FC) analysis of aMSCs with and without irradiation ...........115

4.5.2 Clonogenic Capacity of irradiated aMSCs ..................................... 115

Figure.4.5.2: Clonogenic capacity of irradiated aMSCs ......................................................116

4.5.3 Radiation-induced DNA damage and repair in aMSCs ...................117

Figure.4.5.3: dsDNA damage assay of aMSCs ................................................................ 120

4.5.4 aMSCs radiation-induced apoptotic response ............................... 121

4.5.5 Radiation-induced cell cycle changes in aMSCs ............................. 122

Figure.4.5.5: Cell cycle assay by flow cytometry ............................................................... 124

Figure.4.5.6: PCR array of gene expression for DNA damage/repair signaling pathways .....127

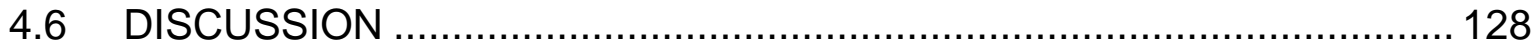

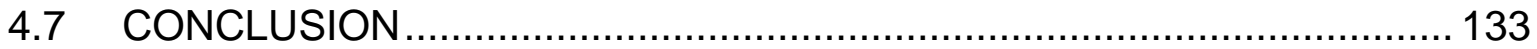

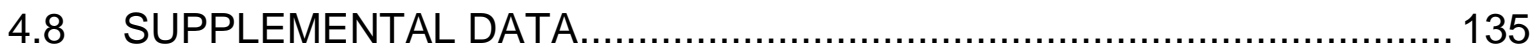

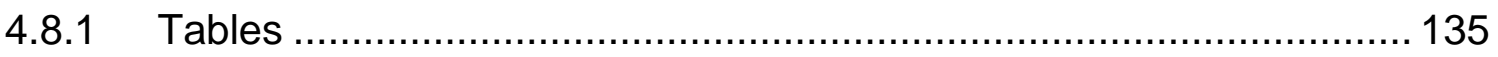

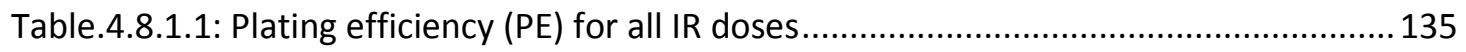

Table.4.8.1.2: Listing the up regulated and down regulated DNA damage/repair related genes

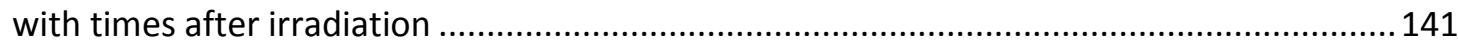

Table.4.8.1.3: List of all tested genes ............................................................................. 146

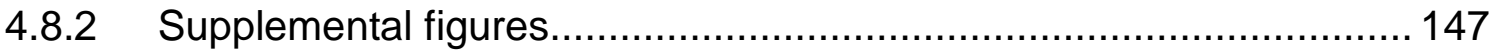


Figure.4.8.2.1.Supplemental: aMSCs multi-lineage differentiation after ionizing radiation

(complementary of Figure.4.5.1)...

Figure 4.8.2.2.Supplemental: MSCs surface antigens expression in aMSCs after different radiation doses up to 7 days after irradiation 150

Figure.4.8.2.3.Supplemental: Annexin-V/PI Apoptosis Assay 152

\section{Chapter 5 SINGLE DOSE RADIATION-INDUCED ORAL}

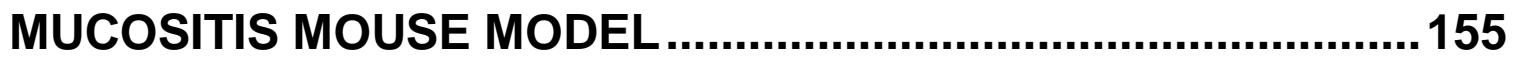

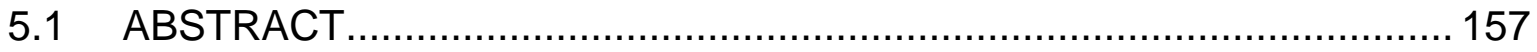

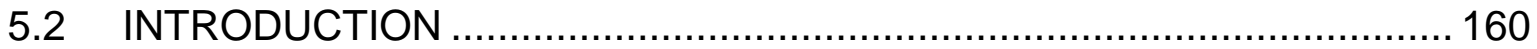

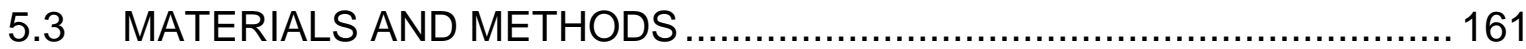

5.3.1 Single dose RIOM mouse model................................................ 161

5.3.2 Tissue collection and processing …........................................... 162

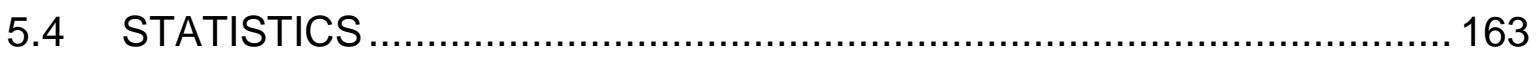

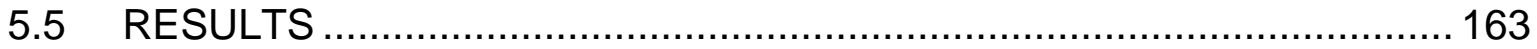

5.5.1 RIOM is a radiation dose dependent injury ................................... 163

Figure.5.5.1: RIOM is a radiation dose dependent injury .................................................. 166

5.5.2 Self-resolved single dose RIOM with $100 \%$ survival rate ................. 167

Figure.5.5.2: RIOM model was established with a single RT dose of $18 \mathrm{~Gy} . . . \ldots \ldots \ldots \ldots \ldots \ldots \ldots . . . . . . . . . . .170$

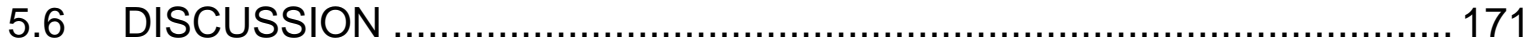

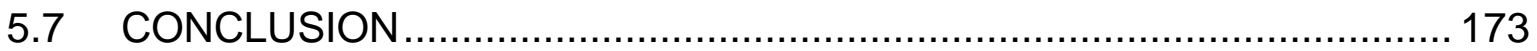

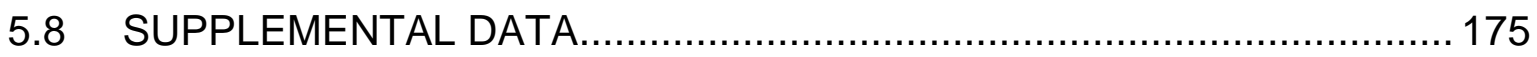

5.8.1 Supplemental figures......................................................... 175

Figure.5.8.1.1.Supplemental: Lost intermolar eminence before physical ulcer appearance 175

Chapter 6 ADIPOSE MESENCHYMAL STROMAL CELLS MINIMIZE \& REPAIR RADIATION-INDUCED ORAL MUCOSITIS.............................................................178

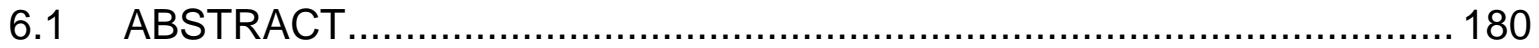

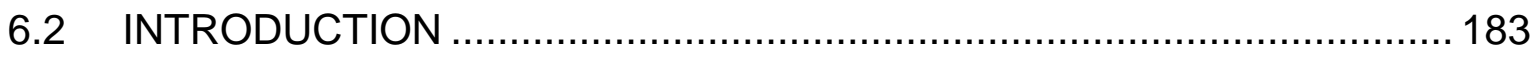

6.3 MATERIALS AND METHODS ……….......................................... 185

6.3.1 Isolation of mouse adipose tissue-derived MSCs (aMSCs) ............... 185

6.3.2 aMSCs functional differentiation assay ....................................... 185

6.3.3 Immunohistochemistry (IHC) staining........................................... 186

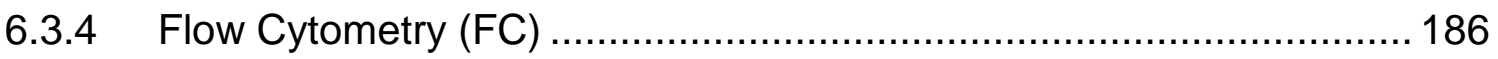




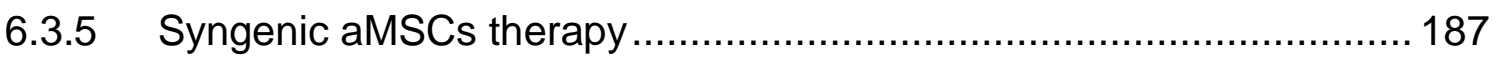

6.3.6 aMSCs conditioned media collection............................................ 187

6.3.7 Single dose RIOM mouse model.................................................. 188

6.3.8 Tissue collection and processing …............................................. 189

6.3.9 Determination of cell survival ......................................................... 190

6.3.10 In-vivo aMSCs imaging .......................................................... 190

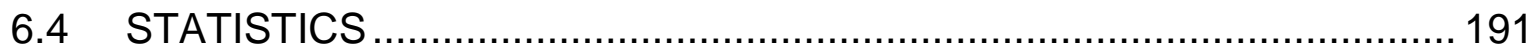

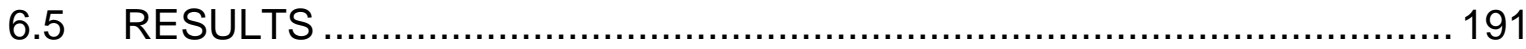

6.5.1 aMSCs maintained their stem cells functionality and phenotype........ 191

Figure.6.5.1: Functional and phenotypic characterization of aMSCs..................................... 192

6.5.2 Self-resolved single dose RIOM with 100\% survival rate ................. 194

Figure.6.5.2: Self-resolved single dose RIOM with 100\% survival rate ................................ 196

6.5.3 Syngenic aMSCs therapy minimized and repaired RIOM ................ 197

Figure.6.5.3: Syngenic freshly isolated aMSCs therapy minimized and repaired RIOM ........ 199

6.5.4 Syngenic aMSCs therapeutic benefits depend on dose size and frequency, number of doses, and the therapy onset time relative to the RT exposure.

Figure.6.5.4: Syngenic aMSCs therapeutic benefits depend on dose size, time of onset, and dosing frequency 202

6.5.5 aMSCs therapy improved RIOM side effects ................................ 203

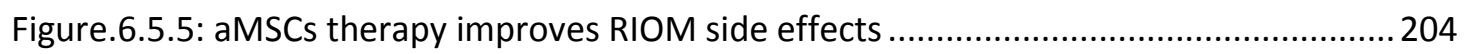

6.5.6 aMSCs do not potentiate Head and Neck cancer cells in-vitro........... 205

Figure.6.5.6: aMSCs do not potentiate Head and Neck cancer in-vitro............................... 205

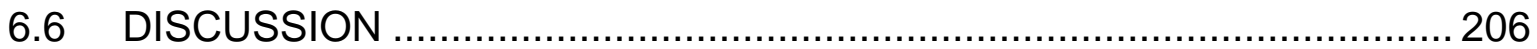

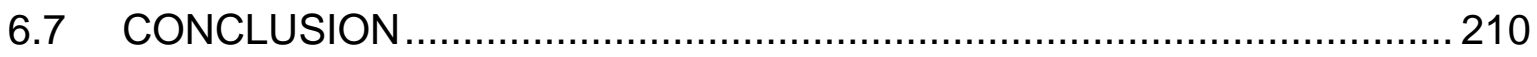

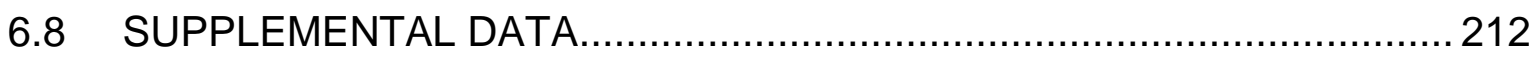

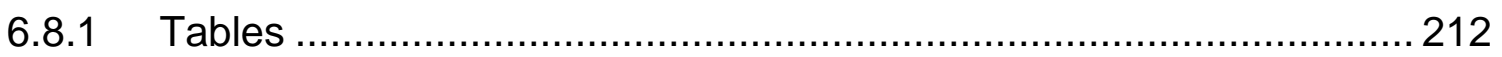

Table.6.8.1.1: The mean \pm SEM of RIOM ulcer in days...................................................... 212

Table.6.8.1.2: 95\% confidence intervals of the clinical parameters of RIOM ulcer in days ... 212

6.8.2 Supplemental figures......................................................... 213

Figure.6.8.2.1.Supplemental: Syngenic freshly isolated aMSCs therapy therapeutic benefits were successfully reproducible 213

Chapter 7 DISCUSSION 


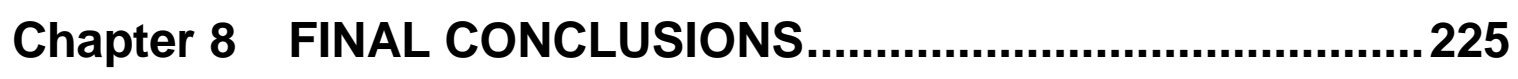

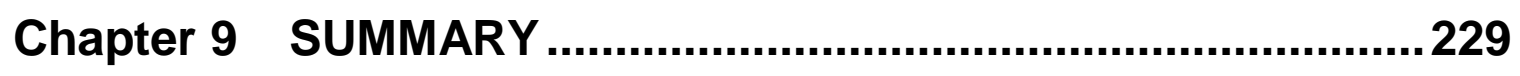

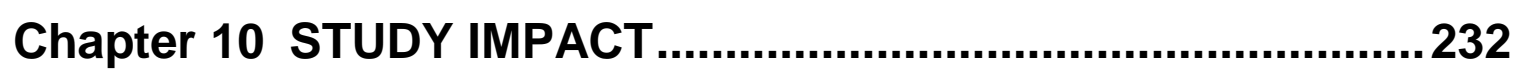

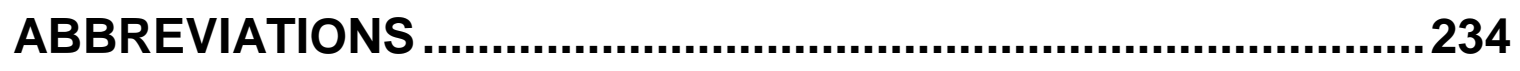

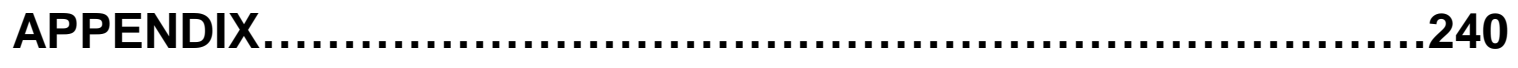

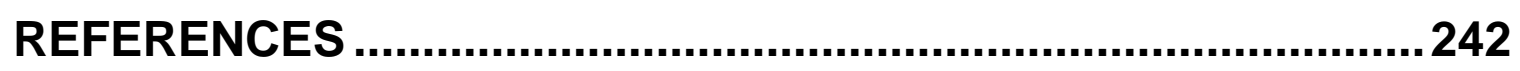


This page is intentionally left blank 


\section{ABSTRACT}

Adipose tissue-derived mesenchymal stromal/stem cells are multipotent progenitor cells present in the stromal vascular fraction of adipose tissue. In addition to their marked proliferation and multi-lineage differentiation potential, they have antiinflammatory and immunomodulatory properties. Additionally, their radiation resistance has been recently proven. Recently, mesenchymal stromal cells have been applied as a cell therapy model in radiation-induced normal tissue injury depending on their anti-inflammatory and radiation resistance properties. Radiationinduced oral mucositis is the most dose-limiting toxicity radiation-induced normal tissue injury been recorded in Head and Neck cancer patients receiving radiotherapy with a $100 \%$ incidence in altered fractionation radiotherapy treated patients. It is a self-limited injury with lethal potential in frail, ill and some elderly patients. It leads to alteration of radiotherapy fractionation in $15 \%$ of patients, cancer treatment interruption, poor local tumor control, and dramatic negative effect on patient's quality of life with $16 \%$ hospitalization incidence. Many local and systemic treatments and management procedures have been developed to reduce the severity and/or the duration of such oral injury. Yet, no single therapy has been shown to satisfy the radiation oncologists in controlling such radiation-induced injury. This study is investigating the application of adipose mesenchymal stromal cells in the prevention and/or the abrogation of radiation-induced oral mucositis. Our main objective is to be able to reduce the severity and/or the duration of radiation-induced oral mucositis by the application of adipose tissue-derived mesenchymal stromal cells therapy. 


\section{RESUME}

Les cellules stromales/souches mésenchymateuses dérivées de tissu adipeux sont des cellules progénitrices multipotentes qui sont présentes dans la fraction de stroma vasculaire du tissu adipeux. En plus de leur remarquable capacité de prolifération et leur potentiel de différenciation multilinéaire, elles ont des propriétés anti-inflammatoires et immunomodulatrices. Récemment, les cellules stromales mésenchymateuses ont été appliquées comme thérapie cellulaire aux lésions des tissus sains induites par la radiation, selon leurs propriétés anti-inflammatoires, et aussi leur résistance au rayonnement. La mucite buccale radio-induite représente la plus enregistrée toxicité de tissus qui limite la dose de radiothérapie chez les patients atteints de cancer au niveau de la tête et du cou. La mucite buccale radioinduite a une incidence de $100 \%$ à la radiothérapie avec la fractionnement altérée. Bien qu'il s'agisse d'une blessure autolimitée, elle pourrait être mortelle chez les patients âgés et malades. Elle induit une modification du fractionnement de la radiothérapie pour $15 \%$ des patients, ainsi que l'interruption du traitement du cancer. De plus, cela peut réduire le contrôle local de la tumeur et avoir un effet négatif considérable sur la qualité de vie du patient avec une incidence d'hospitalisation de $16 \%$. Bon nombre de traitements locaux, systémiques et procédures de gestion ont été développés pour réduire la gravité et / ou la durée de telle lésion orale. Cependant, aucune monothérapie permet un bon contrôle de cette lésion radioinduite. Cette étude teste l'application des cellules stromales mésenchymateuses adipeuses pour la prévention et / ou de la guérison des mucite buccale induite par la radiothérapie. 


\section{AKNOWLEDGEMENTS}

This work has been conducted at the JGH Radiation Oncology department translational research lab, directed by my supervisors, Dr. Thierry Muanza and Dr. Nicoletta Eliopoulos. It was supported by Run-To-Conquer-Cancer (RTCC) and Lady Davis Institute/Toronto Dominion bank studentships. I was the recipient of the PhD studentship award from Fonds de récherche du Quebec Santé (FRQS) the 20142015 and 2015-2016 academic years.

Conferences travel costs were covered by funding from the Experimental Medicine department of McGill University, Faculty of Medicine, LDI, Quebec's Réseau ThéCell, and McGill's Centre for Bioinformatics/Systems Biology Training Program.

Dr. Slobodan Devic and Dr. Alasdair Syme (from Radiation Oncology department) provided the radiation setup for our in-vitro and in-vivo studies.

All members of our radiation oncology translational lab were cooperative in fair use of the lab equipment that allowed us to progress in our work in a time efficient manner.

The LDI animal facility personnel took excellent care of the test mice during the study. Special thanks to Kathy Forner (director), Yhvans Chery (co-director) and the animal technicians. 
The LDI flow cytometry facility manager, Dr. Christian Young, helped us in training and data analysis. The LDI technicians for the freezers, liquid Nitrogen and PCR facilities also provided appreciated help.

Summer intern, Mostafa Shalaby (Marymount academy, then Dawson College) helped for some experimental procedures and data analysis.

Ahmed Maria provided the final editing of the thesis.

All my PhD committee members; Dr. Volker Blank (advisor), Dr. Peter Siegel (member), Dr. Slobodan Devic (member), and Dr. Danuta Radzoich (member) guided me throughout my annual $\mathrm{PhD}$ committee meetings, suggesting experiments, providing ideas and discussing my results.

Salwa Maria, and Ola Maria helped me in thesis editing and formatting.

My Supervisors, Dr. Thierry Muanza, and Dr. Nicoletta Eliopoulos exerted great efforts with me through their direction and advices for experimental design, results discussion, and manuscript and thesis revision.

Widad Souami performed the French translation of the English abstract, and then reviewed by my supervisor, Dr. Muanza. 


\section{DEDICATIONS}

I dedicate this work to my father who directed me towards stem cells research as a future hope for treating certain disorders, which show little or no improvement with traditional therapies.

I dedicate this work to my mother who was and is always supporting me since I started studying and taught me patience and perseverance during all my life. I dedicate this work to my sisters and my brother who always support me and help me in all my studies.

I dedicate this work to my wife and my parents-in-law for their advices and support. I dedicate this work to my supervisors who exerted enormous efforts to lead me through all my PhD study.

I dedicate this work to all my professors, teachers and colleagues. 


\section{PREFACE AND CONTRIBUTIONS OF THE AUTHORS}

This thesis is constructed of two reviews and three manuscripts.

The two reviews were written by Osama Maria and revised by my supervisors, Dr.

Thierry Muanza and Dr. Nicoletta Eliopoulos.

\section{The $1^{\text {st }}$ manuscript contributions were as follows:}

- Osama Maria: conception and design, collection and/or assembly of data, data analysis and interpretation, manuscript writing, approval of manuscript.

- Slawomir Kumala: Conception and design

- Mitra Heravi: Conception and design

- Alasdair Syme: Conception and design

- Nicoletta Eliopoulos: Conception and design, provision of study material, data analysis and interpretation, final approval of manuscript.

- Thierry Muanza: Conception and design, financial support, provision of study material, data analysis and interpretation, final approval of manuscript.

\section{The $2^{\text {nd }}$ manuscript contributions were as follows:}

- Osama Maria: conception and design, collection and/or assembly of data, data analysis and interpretation, manuscript writing, approval of manuscript.

- Alasdair Syme: Conception and design

- Nicoletta Eliopoulos: Conception and design, provision of study material, data analysis and interpretation, final approval of manuscript.

- Thierry Muanza: Conception and design, financial support, provision of study material, data analysis and interpretation, final approval of manuscript.

The $3^{\text {rd }}$ manuscript contributions were as follows: 
- Osama Maria: conception and design, collection and/or assembly of data, data analysis and interpretation, manuscript writing, approval of manuscript.

- Mostafa Shalaby: Collection and/or assembly of data, data analysis.

- Alasdair Syme: Conception and design.

- Nicoletta Eliopoulos: Conception and design, provision of study material, data analysis and interpretation, final approval of manuscript.

- Thierry Muanza: Conception and design, financial support, provision of study material, data analysis and interpretation, final approval of manuscript. I have written my thesis and my two supervisors, Dr. Thierry Muanza and Dr. Nicoletta Eliolpoulos, did the revision of it.

Our thesis's distinct contributions to knowledge and original scholarship elements are as follow:

1. We were the first to address the ionizing radiation resistance of adipose tissue-derived mesenchymal stromal cells describing and qualifying their radio-biological response.

2. We were the first to generate a single dose radiation-induced oral mucositis mouse model with the longest possible and recorded oral mucositis inflammatory and ulcerative phase.

3. We were the first to use syngenic freshly cultured adipose tissue-derived mesenchymal stromal cells in prevention and treatment of radiation-induced oral mucositis achieving such markedly significant $72 \%$ reduction in the injury duration. 
This page is intentionally left blank 


\section{Chapter 1 INTRODUCTION}

\subsection{RADIATION-INDUCED ORAL MUCOSITIS (RIOM)}

The term Radiation-Induced Oral Mucositis (RIOM) was first known by the end of the last century when it was identified as a side effect of radiotherapy in Head and Neck treated cancer patients. RIOM is a normal tissue toxicity side effect for radiation (RT) therapy in Head and Neck cancer patients [1, 2]. It is recorded in $80 \%$ in Head and Neck cancer patients receiving RT. In altered fractionation radiotherapy, RIOM's incidence is $100 \%[1,2]$. RIOM is considered one of the major RT dose-limiting toxicities $[3,4]$. RIOM challenges the radiation oncologists and leads to alteration in RT dose fractionation in $15 \%$ of patients with cancer treatment interruptions leading to poor local tumor control with narrow therapeutic ratio. RIOM begins as asymptomatic inflammatory hyperemia with edema and progresses to confluent desquamation, necrosis and deep ulceration exposing the underlying connective tissue. Complicating secondary infection by candida and Gram negative bacteria can occur in already immunocompromised cancer patients. RIOM is known to be a selflimited inflammation. More importantly, RIOM is a potentially lethal injury in week, elderly and ill patients that significantly deteriorates patient's quality of life especially with altered fractionation $\mathrm{RT}[1,5,6]$.

RIOM is a mucosal barrier injury with 4 well described inflammatory phases. In 2004, Scully C. el al. gave a comprehensive understanding of 4 inflammatory stages during the clinical course of RIOM. The first stage is the localized asymptomatic hyperemia and edema stage as a direct result of the high energy delivered to the tissue. The next stage is the epithelial devitalization, ulceration and confluent desquamation stage as 
a result of the underlying inflammatory reaction with various pro-inflammatory cytokine release and infiltration of inflammatory cells, e.g. MPO-4 positive leukocytes, neutrophils, macrophages, and CD34 positive stem cells. The next stage is the necrotic tissue phase during which the possibility of secondary infection is high. The final stage is the fibrotic stage and/or repopulation $[3,7]$.

Different staging and scoring scales have been developed in order to correctly diagnose and manage the injury. The scoring scales most widely used are the National Cancer Institute Common Toxicity Criteria (NCI CTC) classification and the Radiation Therapy Oncology Group [RTOG] and the European Organization for Research and Treatment of Cancer [EORTC] (RTOG/EORTC) classification. The World Health's Organization (WHO) classification of RIOM is a common scoring method as well [8].

The severity and the duration of RIOM are the two main factors that needed to be controlled by any proposed treatment. Many therapies and procedures have been tried for RIOM locally and systematically, e.g. local anesthesia, analgesics, antiinflammatory drugs, oral care, midline radiation blocks, benzydamine, oral cryotherapy using ice, exposure to soft Laser, and systemic administration of keratinocyte growth factor (palifermin) $[3,4,9]$. Local application of honey appears to be a very promising RIOM local therapy as well [10-13]. Although pharmacological and non-pharmacological therapies were applied for RIOM, yet, no single therapy was identified to significantly minimize and/or repair RIOM. Such expected significant therapeutic benefit would be mediated through reducing the injury severity and duration to a clinically relevant extent $[2,4,5,12,14-47]$. The inflammatory 
nature of the RIOM directs the current studies towards finding a convenient antiinflammatory therapy for such tissue injury.

In addition, there is always a need to generate a solid and a reproducible RIOM animal model with a long enough inflammatory and ulceration phase in order to allow convenient investigation of the therapeutic benefits of tested anti-inflammatory therapies applied for RIOM.

\subsection{RIOM MOUSE MODEL}

RIOM mouse models have been developed in earlier studies for both fractionated [15, $39,48,49]$ and single dose RT [1, 50-53]. Both models did not have a long enough inflammatory and ulceration phase of RIOM as needed. That short duration ulcerative phase in RIOM mouse models resulted in limitations of the experimental setup and performance. For that reason, we were interested in generating a RIOM mouse model with longer inflammatory and ulceration phase duration that allows better experimental investigation of any anti-inflammatory therapy.

In our current study, we found the highest possible single RT dose that generates the longest non-life threatening RIOM in mice. Histological characterization of such injury at this tissue-damaging radiation dose will enhance the research study to finer and more precise level. 


\subsection{MESENCHYMAL STROMAL/STEM CELLS THERAPY}

Mesenchymal Stromal/Stem Cells (MSCs) are pluripotent progenitor cells found in many biological tissues. They are characterized by expressing certain identifying antigens, proliferative capacity, and ability to differentiate in many cell types [54]. Recently, cellular therapies have been used for minimizing and/or repairing RIOM, implementing cell types that are known to have anti-inflammatory properties such as MSCs. MSCs are multipotent progenitor cells that have multi-lineage differentiation potential and recently identified anti-inflammatory and immunomodulatory properties that have been applied in numerous current preclinical and clinical studies [55-70]. Few clinical data of MSCs therapy in ionizing radiation-induced normal tissue injury; e.g. bone, lung, intestine, and skin injury, showed promising therapeutic benefits. MSCs therapy resulted in hematopoiesis regeneration and reducing osteoradionecrosis in radiation-induced bone injury. MSCs improved the breathing and enhanced the immune function of the lung in radiation-induced lung injury. MSCs improved intestinal mucosal inflammation, hemorrhages, fistulization, pain and diarrhea in radiation-induced intestinal injury. Finally, MSCs regenerated skin ulceration in radiation-induced cutaneous injury [71].

The first MSCs therapy tried for RIOM was done in 2014 by M. Schmidt et al. and concluded that the transplantation of bone marrow (BM) or BM-derived MSCs (bmMSCs) could modulate RIOM in a fractionated RT mouse model depending on the time of transplantation [48]. Nevertheless, in another study they showed that BM transplantation had no therapeutic effect on RIOM in single dose RT when compared to mobilization of endogenous BM stem cells [72]. There were promising 
results shown in these two studies. The hypothesis of applying the anti-inflammatory properties of MSCs in countering the inflammatory injury induced by RT is considered a logically accepted theory.

MSCs can be isolated from different tissue origins. However, MSCs isolated from adipose tissue are characterized by their enhanced anti-inflammatory properties, production of higher levels of the anti-inflammatory cytokine Interleukin-10 (IL-10), high yield upon expansion in cultures, ease of isolation, and source abundance [73]. Adipose tissue-derived mesenchymal stem/stromal cells (aMSCs) are multipotent progenitor cells located in the stromal vascular fraction (SVF) of adipose tissue [74]. They express surface antigens that are expected on MSCs; e.g. Sca1, CD106, CD105, CD73, CD29, and CD44, and lack the expression of hematopoietic stem cells (HSCs) surface antigens (e.g. CD11b and CD45) [74-76]. They have antiinflammatory/immunomodulatory and paracrine effects as well. They have the ability to home to the site of tissue injury caused by irradiation and inflammation $[74,77$, 78]. aMSCs are promising for cellular therapies due to their prominent antiinflammatory effects, enhancing IL-10 secretion, ease of isolation, high cell count after expansion as well as their source abundance [73].

In radiation oncology regenerative medicine (RORM), aMSCs therapy for radiationinduced normal tissue injury has been investigated recently in a few studies which led to promising therapeutic and clinically relevant effects. aMSCs have been investigated in many studies for cutaneous radiation syndrome [79-83] and photo-aging [84] with significant tissue repair. aMSCs systemic cell therapy led to significant restoration and improvement of acute salivary gland [85] and intestine injuries $[70,86-88]$ induced by 
ionizing radiation (IR). Furthermore, aMSCs have shown promise for successful cell therapy in chronic radiotherapy-induced injuries [80, 89].

These studies urged a need for characterizing the radiobiological response of aMSCs in order to enhance their therapeutic outcome in RORM cell therapies; as that will allow us to determine the future behavior/outcome of aMSCs therapies before or during fractionated radiotherapy $[90,91]$. In that perspective, it was documented that the cell surface antigens found on MSCs; Sca-1, CD29, and CD44 have been linked with cellular radio-resistance [92, 93]. In addition, the surface antigen CD105 presence is important for normal cellular DNA repair [94]. Different mechanisms have been reported to explain this radio-resistance; such as, cell cycle (CC) arrest (G2/M arrest) and activation of double stranded DNA (dsDNA) damage repair; namely the homologous recombination repair (HRR) and non-homologous end-joining repair (NHEJR) [95-99]. These mechanisms were also shown to be responsible for the IR resistance of cancer stem cells (CSC), also known as cancer initiating cells, which have been linked to cancer disease recurrence and aggression [100-103]. These mechanisms were tested in bmMSCs in earlier studies showing that these bmMSCs are relatively radio-resistant $[95,96,104-106]$. Do MSCs from different tissue origins behave similarly? That was an important question we had to answer before trying to use aMSCs therapy for RIOM. To do so, we needed to find a suitable radio-resistant cells to compare their radiobiological responses.

4T1 cells are a highly metastatic triple-negative mouse breast cancer cell line expressing mesenchymal antigens. It has been documented that, these cells have a considerable subpopulation of CSC that confer proven IR resistance $[92,101,107$ - 
111]. These characteristics make these cells a reliable candidate to compare their IR biological response to that of aMSCs.

\subsection{HYPOTHESIS AND RATIONALE}

We hypothesized that aMSCs could minimize and/or repair RIOM owing to their prominent anti-inflammatory properties.

\subsection{OBJECTIVES}

Our study main goal is to investigate the therapeutic effect of aMSCs in RIOM.

Establishing an aMSCs therapy approach for radiation-induced OM would:

1- Minimize radiation-induced normal tissue toxicity.

2- Improve (widen) the tight therapeutic ratio (TR) of irradiated patients, changing it from unfavorable to favorable TR (Figure.1.1).

3- Enhance local tumor control.

4- Increase the rates of organ preservation.

5- Augment the rate of survival of cancer patients. 

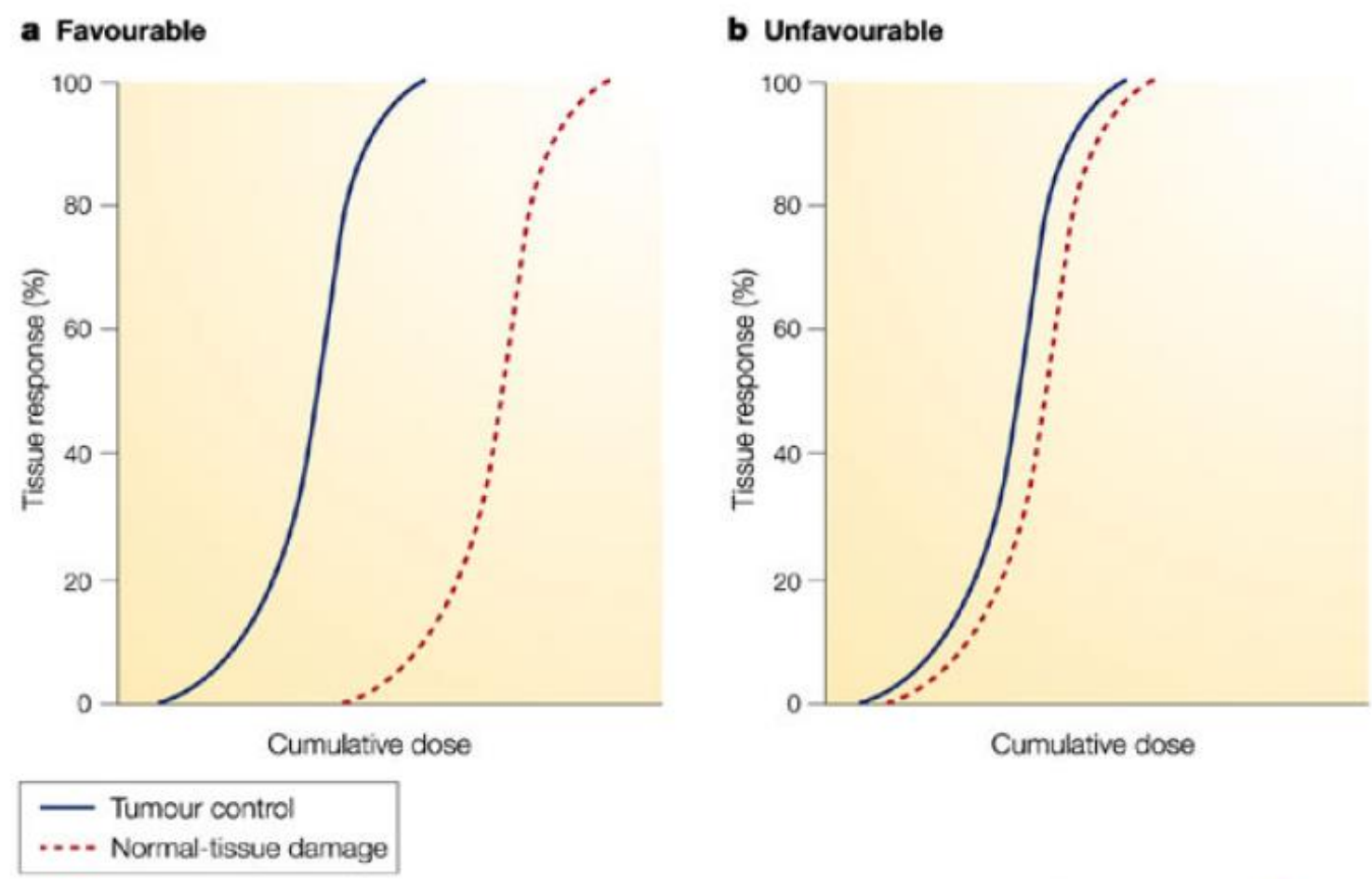

.... Normal-tissue damage

Nature Reviews | Cancer

Figure.1.5.1: The therapeutic index with respect to cumulative dose [112]

\section{Our study's main aims were toFigure.1.2):}

1- Establish the basic research part; e.g. isolation, expansion, characterization, and differentiation of aMSCs.

2- Perform the preclinical study to test aMSCs cellular therapy in RIOM. 


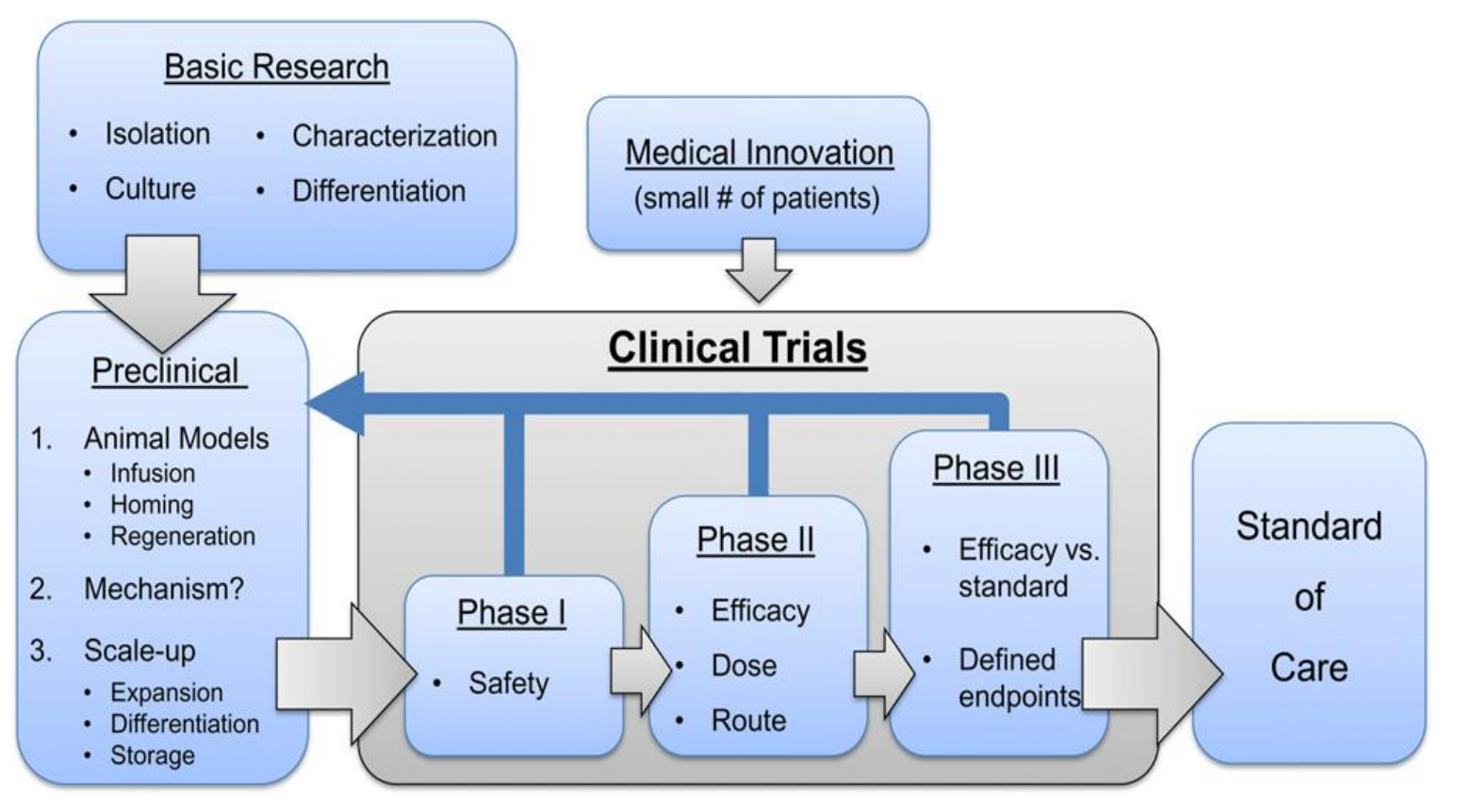

Figure.1.5.2: Stem cells translational research steps from bench to bedside [113, 114]

\section{In order to fulfill these main aims, we have planned our main objective as}

\section{follows:}

1- Isolation, validation and in-vitro characterization of aMSCs.

2- Evaluation of aMSCs radiation sensitivity.

3- Generation of a RIOM mouse model.

4- Testing aMSCs therapy in order to minimize and/or repair RIOM in our mouse model.

5- Investigate the effect of aMSCs therapy on the Head \& Neck cancer cells behaviour. 


\subsection{OUTLINE}

We have structured our manuscript-based thesis as follows:

1- Chapter 1: Introduction

2- Chapter 2: Review on Radiation-induced Oral Mucositis

3- Chapter 3: Review on Mesenchymal Stromal/Stem Cells Therapy in Radiation Oncology Regenerative Medicine

4- Chapter 4: $1^{\text {st }}$ manuscript: Adipose Mesenchymal Stromal Cells Response to lonizing Radiation

5- Chapter 5: $2^{\text {nd }}$ manuscript: Generation of Single Dose Radiation-Induced Oral Mucositis Mouse Model

6- Chapter 6: $3^{\text {rd }}$ manuscript: Adipose Mesenchymal Stromal Cells Minimize and Repair Radiation-Induced Oral Mucositis

7- Chapter 7: Discussion

8- Chapter 8: Final conclusions

9- Chapter 9: Summary

10- Chapter 10: Study impact 
This page is intentionally left blank 
The next chapter will be a complete review on radiation-induced oral mucositis 


\section{Chapter 2 REVIEW ON RADIATION-INDUCED ORAL}

\section{MUCOSITIS}

Osama Muhammad Maria, MD, MSc ${ }^{1,3,4}$, Nicoletta Eliopoulos, $\mathrm{PhD}^{2,4}$ and Thierry Muanza, MD, MSc $1,3,4,5$

1 Experimental Medicine Department, Faculty of Medicine, McGill University, Montreal, Quebec, Canada

2 Surgery Department, Faculty of Medicine, McGill University, Montreal, Quebec, Canada

3 Radiation Oncology Department, Jewish General Hospital, McGill University, Montreal, Quebec, Canada

4 Lady Davis Institute for Medical Research, Jewish General Hospital, McGill University, Montreal, Quebec, Canada

5 Oncology Department, McGill University, Montreal, Quebec, Canada

\section{AUTHOR CONTRIBUTIONS}

- Osama Maria: Conception and design, collection and/or assembly of data, review writing, final approval of the review.

- Nicoletta Eliopoulos: Conception, design and final approval of the review.

- Thierry Muanza: Conception and design, financial support and final approval of the review.

\section{THE CORRESPONDING AUTHOR}




\section{Dr. Thierry Muanza, MD MSc FRCPC}

Radiation Oncology Translational Research Lab, Department of Radiation Oncology, Jewish General Hospital and Lady Davis Institute Research Centre, McGill University

3755 Côte-St.-Catherine Road, Suite G002, Montréal, Québec, Canada, H3T 1 E2 Tel: +1 (514)-340-8288, Fax: + 1 (514)-340-7548, Email: tmuanza@yaoo.com

Disclaimer: None 
KEY WORDS: Chemotherapy, Oral Mucositis, Radiation, Radiotherapy, Normal Tissue Injury, Pathobiology, Mesenchymal Stromal/Stem cells 


\section{$2.1 \quad$ ABSTRACT}

Radiation-induced oral mucositis (RIOM) is a major dose-limiting toxicity in Head and Neck cancer patients. It is a normal tissue injury that has adverse effects on patient quality of life and cancer therapy continuity. It is a challenge for radiation oncologists since it leads to change in dose fractionation, cancer therapy interruption, and poor local tumor control. RIOM occurs in $100 \%$ of altered fractionation radiotherapy Head and Neck cancer patients. At the USA, its economic cost was estimated to reach $\$ 17,000.00$ USD per patient with Lung and Head and Neck cancers. This review will discuss RIOM definition, epidemiology, impact and side effects, pathogenesis, different scoring scales, diagnosis, differential diagnosis, prevention and treatment.

\subsection{DEFINITION}

Radiation-induced oral mucositis (RIOM) (Figure.2.2.1) is one of the major ionizing radiation toxicities and normal tissue injuries that result from radiotherapy [1]. RIOM was first termed in 1980 as a side effect of radiotherapy (RT) in cancer patients [4]. RIOM is a 7-98 day (Figure.2.2.2) $[1,115]$ duration normal tissue injury that starts as an acute inflammation of oral mucosa, tongue \& pharynx after RT exposure. This is accompanied with recruitment of various inflammatory cells and release of inflammatory cytokines, chemotactic mediators and growth factors. RIOM might progress to an acute life-threatening stage as a result of severe physical obstruction of food and water intake with subsequent weight loss, and septic complication due to lost protective epithelial and basement membrane barriers. This leads to limitations 
of local tumor control due to cancer treatment interruption and changing the radiation dose fractionation $[6,116-118]$. Studies suggested the stages of progression of RIOM as initial hyperemia and erythema during the pre-ulcer phase where there is release of various pro-inflammatory cytokines from epithelial, vascular, and connective tissue cells at the site of tissue injury. This is followed by the epithelial phase with various degrees of desquamation and basement membrane damage with loss of the protective barrier ending with the physical appearance of the ulceration. The post-ulcer phase varies according to the extent of the tissue toxicity and it may acquire secondary infection with Gram negative bacteria or yeast with microcoagulation of the vasculature that worsens the inflammation by the local ischemia with more necrotic tissue yield. The final stage will be the healing phase and fibrosis. Figure.2.2.3 is showing grade III-IV RIOM [4, 119, 120].

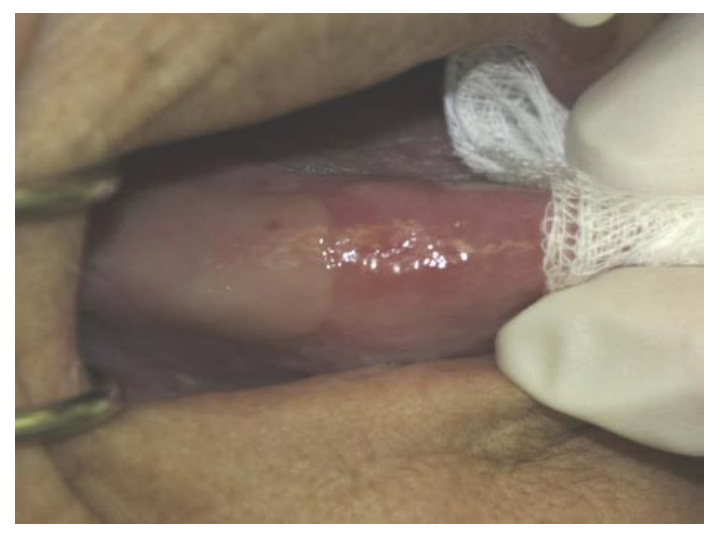

Figure.2.2.1: Grade III RIOM on WHO scale

RIOM Detected 3 months after completion of hypo-fractionated RT. The right portion of the tongue is showing a pseudo-membrane covering a large ulceration; the left portion has a similar ulcer. The patient was unable to eat solid food [121]. 


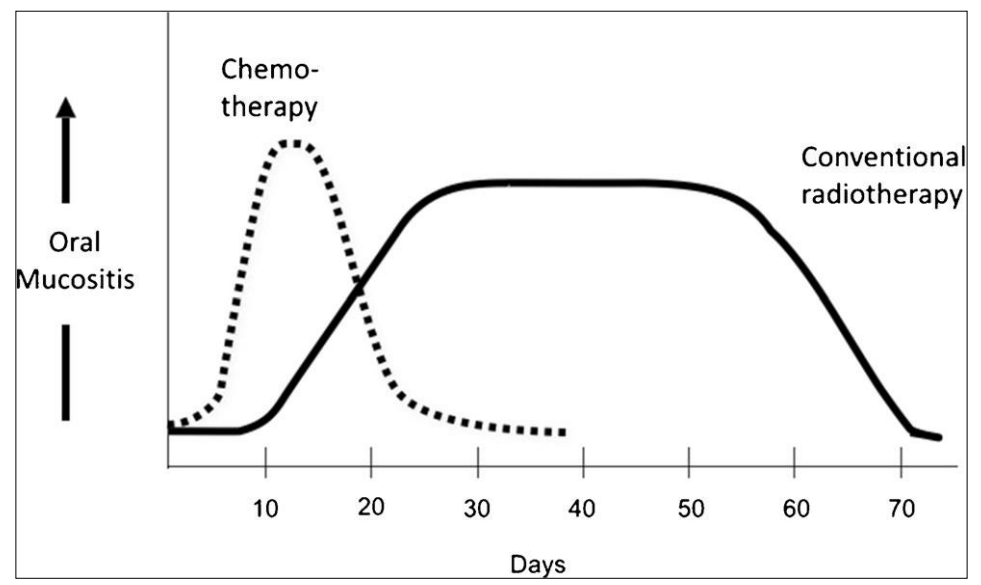

Figure.2.2.2: RIOM duration, onset, and resolution [115]

RIOM usually starts 2 weeks after RT with duration ranges of 2-4 weeks. However, with moderately to severely ill patients, the duration may increase with risk of secondary bacterial or yeast infection [115].

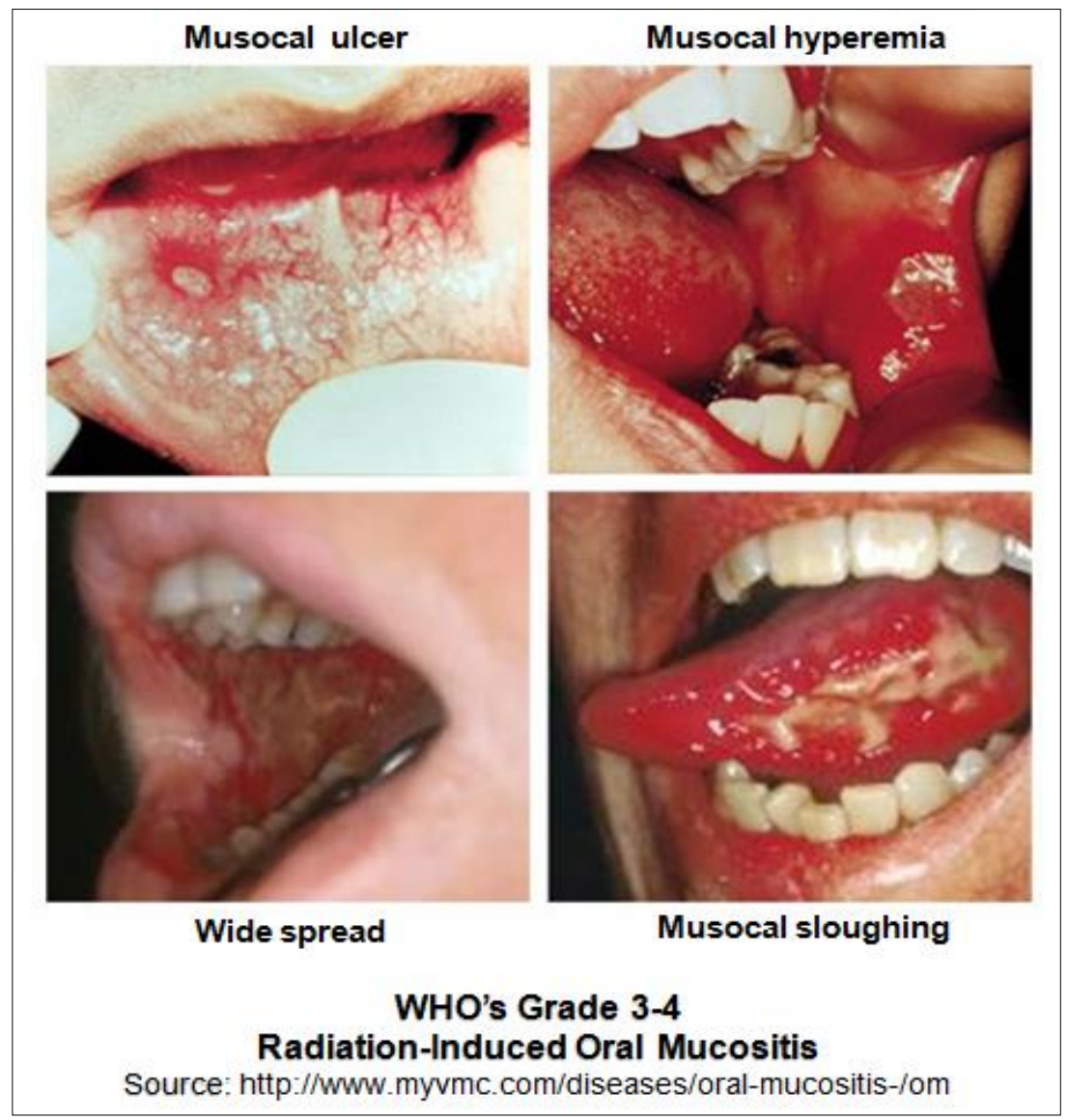


Figure.2.2.3: WHO's grade III-IV RIOM showing mucosal ulcer, hyperemia, and wide spread epithelial sloughing.

\subsection{RIOM EPIDEMIOLOGY (INCIDENCE, PREDICTORS, AND RISK}

\section{FACTORS)}

RIOM occurs in up to $80 \%$ of Head and Neck cancer irradiated patients and reaches up to $100 \%$ in patients with altered fractionation Head and Neck cancer. RIOM of grade 3 and 4 have been recorded in $56 \%$ of Head and Neck cancer patients treated with radiotherapy $[1,122]$.

Many risk factors have been identified for RIOM. These risk factors include:

chemotherapy, bad oral hygiene, below average nutritional stratus, missing the use of antibiotics at early stage mucositis, and smoking [123].

Table.2.3.1 shows the significant predictors for the prevalence of severe RIOM and the symptoms of RIOM in a longitudinal study of patients with oral cavity cancer among Head and Neck outpatients of a radiation department at a major medical center in Taiwan [124]. They used the Generalized Estimating Equations (GEE) in order to analyze the predictive factors of prevalence of severe RIOM and RIOMrelated symptoms. They found significant predictors for the prevalence of severe RIOM, which included the type of treatment (RT vs. CCRT) [CCRT = concomitant chemo-radiotherapy], cumulative radiation dose, smoking, and body mass index (BMI). Patients who received CCRT (Coef. 0.145, $\mathrm{p}<.05$ ), a higher cumulative radiation dose (Coef. 0.000, $p<.01$ ), smoking (Coef. 0.090, $p<.01$ ), and lower BMI 
(Coef. $0.005, p<.05$ ) were at high risk to develop severe RIOM. RIOM-related symptoms were also predicted by the type of treatment (RT vs. CCRT) (Coef. 1.618, $p<.05$ ), cumulative radiation dose (Coef. 0.003, $p<.05$ ), and smoking (Coef. 1.759, $\mathrm{p}<.001)$.

\begin{tabular}{|c|c|c|c|c|c|c|}
\hline Variable & Coef. & Std. Err. & $z$ & $P>z$ & \multicolumn{2}{|c|}{ [95\% Conf. Interval] } \\
\hline \multicolumn{7}{|c|}{ Prevalence of severe radiation-induced mucositis model } \\
\hline $\begin{array}{l}\text { Type of treatment } \\
\text { (RT vs. CCRT) }\end{array}$ & 0.145 & 0.06 & 5.65 & 0.017 & 0.03 & 0.26 \\
\hline $\begin{array}{l}\text { Cumulative radiation } \\
\text { dose (cGy) }\end{array}$ & 0.000 & 0.01 & 16.47 & 0.001 & -0.00 & 0.01 \\
\hline Smoking (No vs. Yes) & 0.090 & 0.03 & 8.52 & 0.004 & 0.03 & 0.15 \\
\hline Body Mass Index & -0.005 & 0.01 & 4.56 & 0.033 & -0.10 & 0.00 \\
\hline Time & 0.417 & 0.09 & 23.56 & 0.001 & 0.25 & 0.59 \\
\hline Intercept & -0.277 & 0.17 & 2.72 & 0.099 & -0.61 & 0.05 \\
\hline \multicolumn{7}{|c|}{ Symptom of radiation-induced mucositis model } \\
\hline $\begin{array}{l}\text { Type of treatment } \\
\text { (RT vs. CCRT) }\end{array}$ & 1.618 & 0.49 & 10.76 & 0.001 & 0.65 & 2.59 \\
\hline $\begin{array}{l}\text { Cumulative radiation } \\
\text { dose (cGy) }\end{array}$ & 0.003 & 0.01 & 4.03 & 0.045 & -0.01 & -0.01 \\
\hline Smoking (No vs. Yes) & 1.759 & 0.41 & 18.50 & 0.000 & 0.96 & 2.56 \\
\hline Body Mass Index & -0.002 & 0.05 & 0.00 & 0.973 & -0.09 & 0.09 \\
\hline Time & 1.338 & 1.34 & 2.57 & 0.109 & -0.48 & 4.77 \\
\hline Intercept & 6.023 & 2.77 & 4.74 & 0.030 & 0.60 & 11.45 \\
\hline
\end{tabular}

Table.2.3.1: Data analysis for RIOM predictors using IBM SPSS version 21.0 (Armonk, NY, USA)

Significant predictors for the prevalence of severe RIOM ( ${ }^{*}$ CCRT, cumulative radiation dose, smoking, and low BMI) and the symptoms of RIOM in a longitudinal study of patients with oral cavity cancer among Head and Neck patients (CCRT, cumulative radiation dose, and smoking). ${ }^{*}$ CCRT = concomitant chemo-radiotherapy [124]. 
These significant predictors are implemented by radiation oncologists in order to minimize and/or prevent the RIOM.

June Eilers and Rita Million have summarized the patient-linked factors leading to increased risk for RIOM (Table.2.3.2) [125]. They found that very young age, female gender, poor oral health and hygiene, decreased saliva secretion, low body mass index, poor renal function with elevated serum creatinine level, smoking, and previous history of RIOM are risk factors predicting the development of RIOM in Head and Neck cancer patients [125].

\begin{tabular}{|c|c|}
\hline Age & $\begin{array}{l}\text { Increased risk in the very young age } \\
\text { due to increased cell turnover } \\
\text { rate, and in old age because of } \\
\text { decreased rate of healing }\end{array}$ \\
\hline Gender & $\begin{array}{l}\text { Mixed findings to date with a trend } \\
\text { towards increased risk in females }\end{array}$ \\
\hline $\begin{array}{l}\text { Oral health and } \\
\text { hygiene }\end{array}$ & $\begin{array}{l}\text { A clean, well-maintained oral cavity } \\
\text { is less likely to develop problems } \\
\text { related to mucositis }\end{array}$ \\
\hline $\begin{array}{l}\text { Salivary secretory } \\
\text { function }\end{array}$ & $\begin{array}{l}\text { Decreased saliva causes increased } \\
\text { problems with mucositis }\end{array}$ \\
\hline Genetic factors & $\begin{array}{l}\text { Potential for increased resistance to } \\
\text { mucositis in some individuals- } \\
\text { specifics yet to be identified }\end{array}$ \\
\hline Body mass index & $\begin{array}{l}\text { Poorly nourished individuals are } \\
\text { more likely to experience } \\
\text { increased breakdown and } \\
\text { delayed healing }\end{array}$ \\
\hline Renal function & $\begin{array}{l}\text { Elevated creatinine potentially leads } \\
\text { to increased mucotoxicity }\end{array}$ \\
\hline Smoking & $\begin{array}{l}\text { Affects microcirculation and } \\
\text { potentially delays healing }\end{array}$ \\
\hline $\begin{array}{l}\text { Previous cancer } \\
\text { treatment }\end{array}$ & $\begin{array}{l}\text { History of problems with mucositis } \\
\text { as a result of previous cancer } \\
\text { treatment }\end{array}$ \\
\hline
\end{tabular}

Table.2.3.2: Patient-linked factors leading to increased risk for OM [125] 


\subsection{RIOM IMPACT AND SIDE EFFECTS}

RIOM side effects and sequels include: oral pain in $69 \%$ of patients, dysphagia in $56 \%$ of patients, opioid use in $53 \%$ of patients, weight loss of 3 to $7 \mathrm{~kg}$, feeding tube insertion and hospitalization (ICU admission) in 15\% of patients, and modification or interruption of treatment in $11-16 \%$ of patients $[1,122,126]$.

At the USA, RIOM may add up to $\$ 1,700.00-6,000.00$ USD per patient depending of the inflammatory grade of the injury [122]. RIOM treatment added an economic cost that was estimated to increase up to $\$ 17,000.00$ USD per patient treated for Lung and Head and Neck cancers [126].

RIOM injury challenges radiation oncologists from many aspects, e.g. radiation-dose limitations, changes in dose fractionation protocol, and dramatic negative effects on patients' quality of life [1].

The major clinical consequences include hospital admission or extended hospitalization for total parenteral nutrition, intravenous analgesia, and intravenous antibiotics. $62 \%$ of patients require hospitalization, and $70 \%$ of patients with Grade 3-4 oral mucositis require feeding tube insertion. Reduction or cessation (doselimiting toxicity) of cancer treatment occurs in $35 \%$ of patients [127].

\subsection{PATHOGENESIS AND SUGGESTED MECHANISTIC}

\section{PATHWAYS}

The pathophysiology of RIOM is not fully understood. The recent studies proposed that the pathogenesis of RIOM is composed of 4 phases. An initial 
inflammatory/vascular phase, an epithelial phase, a (pseudomembraneous) ulcerative/bacteriological phase, and a healing phase $[4,6]$.

At the inflammatory phase, the tissue injury results in the release of inflammatory

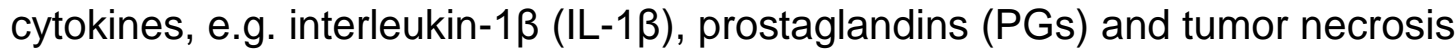
factor- $\alpha$ (TNF- $\alpha$ ) from the resident cells; epithelial, endovascular and connective tissue. These mediators might increase the damage by increasing the vascular permeability and leading to more infiltrating inflammatory cells. Stem cells home to the site of the tissue injury accompanying other innate immunity components; e.g. the MPO positive leucocytes, macrophages, and neutrophils [74]. There are some anti-inflammatory cytokines, such as Interleukin-10 (IL-10) and Interleukin-11 (IL-11) that work to minimize the injury as well.

The epithelial phase starts within a week by the apoptotic and cytotoxic effects of radiotherapy on the proliferating basal cells. That is why the recovery period is dependent on the rate of epithelial turnover which could be enhanced by growth factors like epidermal growth factor (EGF) and keratinocyte growth factor (KGF).

The epithelial breakdown ends with the ulceration phase which starts after a week where there will be lost epithelium, disrupted basement membrane, formation of ulcer pseudo-membrane, and inflammatory exudates. The ulceration stage is very painful, since the protective barrier that covers the nerve endings at the lamina propria is lost [128]. The resulting micro-coagulation and neutropenic state facilitate the Gram negative bacteria and yeast colonization with the production of secondary infection. Bacterial exotoxins may aggravate the inflammatory reaction by inducing 
mononuclear burst with the release of more IL-1 $\beta$, TNF- $\alpha$, and nitric oxide (NO) [3, $119,120,126]$

\begin{tabular}{l}
\hline Signaling Pathways Involved in the \\
Development of Mucositis \\
\hline Nitrogen metabolism \\
\hline Toll-like receptor signaling \\
\hline NF-KB signaling \\
\hline B-cell receptor signaling \\
\hline P13K/AKT signaling \\
\hline Cell cycle: G2/M DNA damage checkpoint receptor \\
\hline p38 MAPK signaling \\
\hline Wnt/B-catenin signaling \\
\hline Glutamate receptor signaling \\
\hline Integrin signaling \\
\hline VEGF signaling \\
\hline IL-6 signaling \\
\hline Death receptor signaling \\
\hline SAPK/JNK signaling \\
\hline Reprinted with permission from Sonis et al23 \\
Abbreviaions: NF-KB $=$ nuclear factor kappa-B; MAPK $=$ mitogen-activated protein kinase; \\
VEGF = vascular endothelial growth factor; IL-6 $=$ interleukin-6
\end{tabular}

Table.2.5.1: Signaling Pathways Involved in the Development of Mucositis [129]

Signaling pathways suggested to be involved in RIOM pathobiology include:

Nitrogen metabolism, Toll-like receptor signaling, NF-kB signaling, B-cell receptor signaling, P13K/AKT signaling, cell cycle: G2/M DNA damage checkpoint receptor, p38 MAPK signaling, Wnt/B-catenin signaling, glutamate receptor signaling, integrin signaling, vascular endothelial growth factor (VEGF) signaling, IL-6 signaling, death receptor signaling, and SAPK/JNK signaling (Table.2.5.2) [128, 129]. 
Sonis, 2004 [126], suggested a five stage (phase) OM injury by both radiotherapy (RT) and chemotherapy (CT): initiation, signaling and amplification, ulceration and healing (Figure.2.5.1) [126].

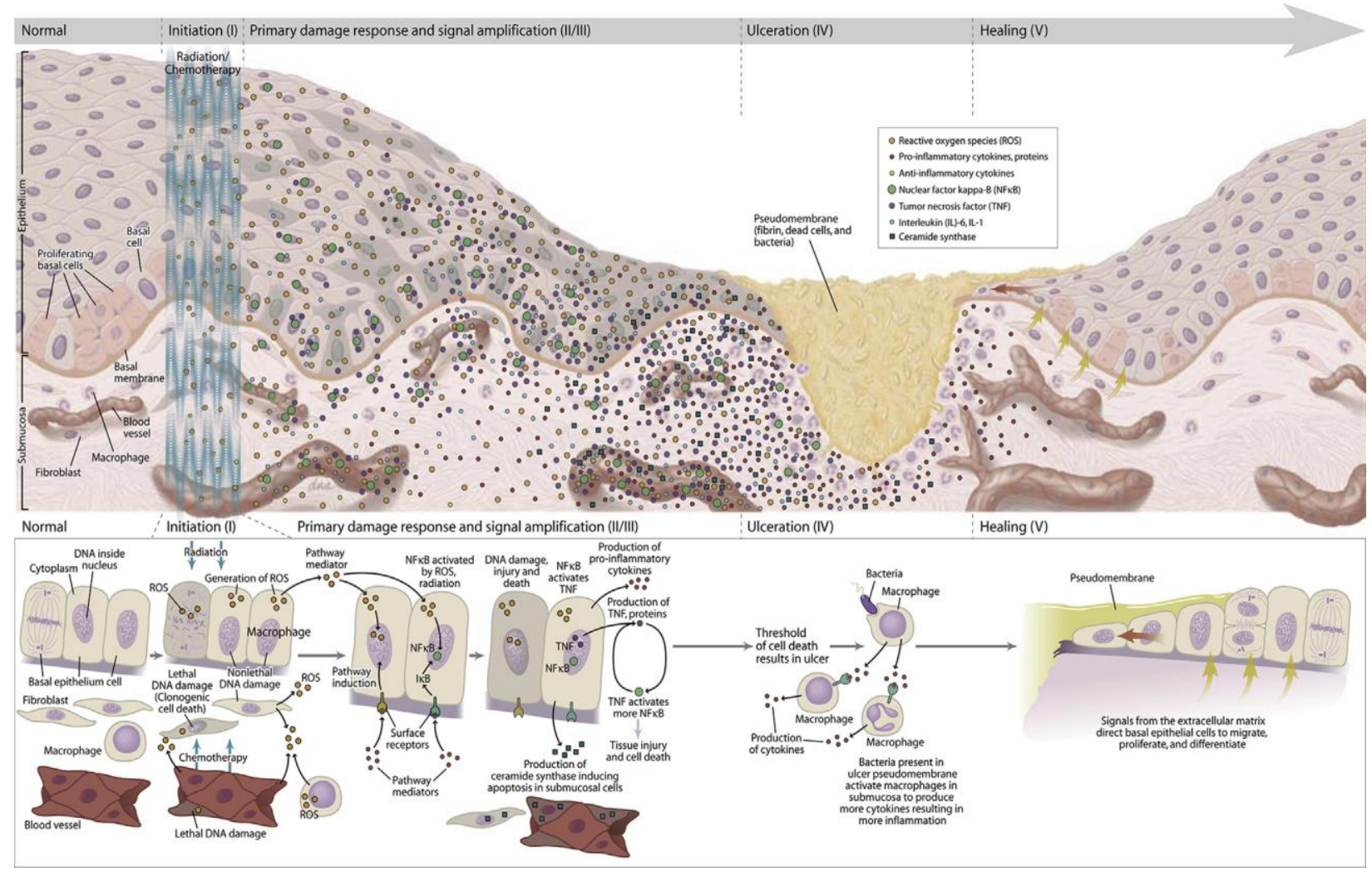

Figure.2.5.1: Pathobiology of oral mucositis (OM)

Sonis [126] suggested five stages (phases) of OM injury by both radiotherapy (RT) and chemotherapy (CT): initiation, signaling and amplification, ulceration and healing. The pathogenesis of each phase is illustrated (From Sonis ST. Pathobiology of oral mucositis: novel insights and opportunities. J Support Oncol 2007; 5:3-11) [129]. 
Redding, 2009 [130] summarized Sonis's, 2004 [15] RIOM pathobiology phases

(Figure.2.5.2). The initiation phase with RT and/or CT injury results in direct and lethal DNA damage with the release of reactive oxygen species (ROS) from epithelial and vascular endothelial cells, fibroblasts and tissue macrophages with the following amplification. During the primary damage response, the DNA damage and ROS act through 3 major pathways: (1) fibronectin breakdown which stimulates the macrophages leading to activation of the matrix metalloproteinase (MMPs), (2) NF$\kappa \mathrm{B}$ activation which stimulates the gene expression and the release of proinflammatory cytokines; e.g. TNF- $\alpha$, IL-1 $\beta$, and IL-6, and (3) ceramide pathway through sphyingomyelinase, and ceramide synthase. The end result will be more tissue injury and stimulated apoptosis [130]. During the signal amplification phase, there is circulating re-stimulation of tissue damage and apoptosis by the major proinflammatory cytokines (TNF- $\alpha, \mathrm{IL}-1 \beta$, and IL-6), NF-kB-mediated gene expression, and ceramide and caspase pathways. The basement membrane protective barrier is lost during the ulceration phase. This leads to Gram negative and yeast secondary infection which adds more pro-inflammatory reactions and complicates the already existing inflammation. The healing phase starts by matrix signaling to basal epithelial cells in order to migrate, proliferate, and differentiate [130]. 

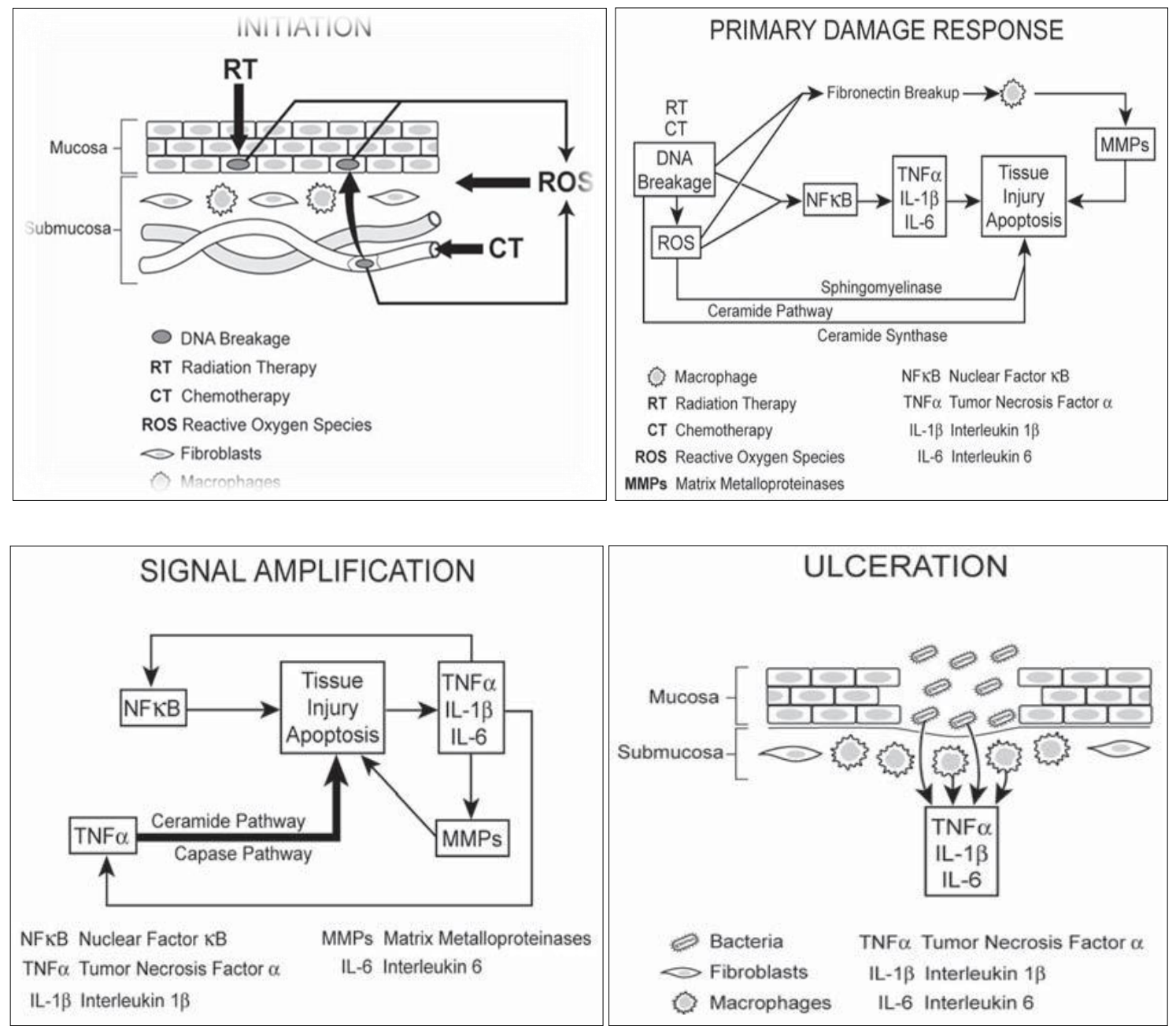

Figure.2.5.2: Redding, 2009 [130], summarized OM pathobiology

Redding's, 2009 [130] summary of RIOM pathobiology phases as a result of RT and/or CT. In brief: initiation phase with RT and/or CT results in direct and lethal DNA damage which leads to release of reactive Oxygen species (ROS) from epithelial, vascular endothelial, fibroblasts and tissue macrophages with cycles of amplifications. Within such primary damage response, the DNA damage and ROS lead to 3 major steps: (1) fibronectin breakdown that activates macrophages ending with stimulation of Matrix Metalloproteinase. (2) NF-KB activation that stimulates the gene expression and release of pro-inflammatory cytokines; e.g. TNF- $\alpha$, IL-1 $\beta$, and IL-6, and (3) ceramide pathway through sphyingomyelinase, and ceramide synthase. The 
result will be more tissue injury and stimulated apoptosis. During the signal amplification phase, there is circulating re-stimulation of tissue damage and apoptosis by the major proinflammatory cytokines (TNF- $\alpha$, IL-1 $\beta$, and IL-6), NF-KB-mediated gene expression, and ceramide and caspase pathways. During the ulceration and loss of the protective barrier, secondary infection adds more pro-inflammatory reactions and complicates the already existing inflammation before the healing phase starts by matrix signaling to basal epithelial cells to migrate, proliferate, and differentiate [21].

Signal amplification during OM from both RT and CT is a main step according to Sonis's, 2004 [15]. RT and CT activate the transcription factor nuclear factor-кB (NF$\kappa \mathrm{B})$ in epithelial, endothelial and mesenchymal cells and macrophages, resulting in up-regulation of genes and production of pro-inflammatory cytokines: tumor-necrosis

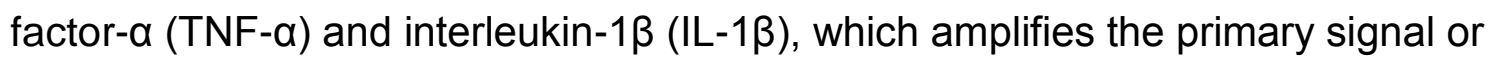
might activate NF-кB. This leads to transcription of genes responsible for mitogenactivated protein kinase (MAPK), cyclooxegenase-2 (COX2) and tyrosine-kinase signaling molecules. These signaling pathways activate matrix metalloproteinases (MMPs) 1 and 3 in the epithelial and lamina propria cells, which collectively cause tissue injury [129] (Figure.2.5.3). 


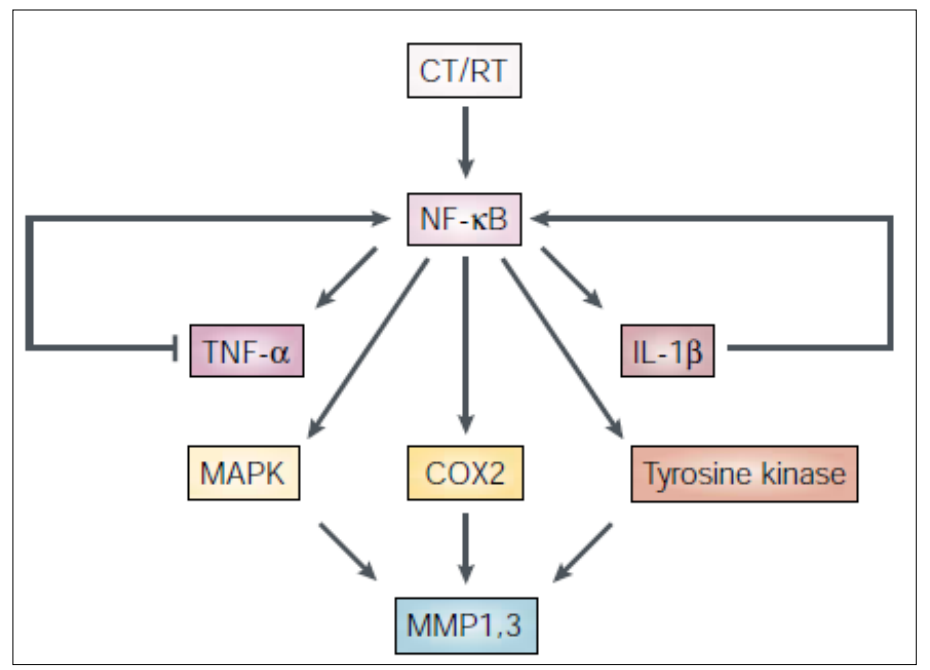

Figure.2.5.3: Signal amplification during OM from both RT and CT [129]

Signal amplification during OM from both RT and CT is mediated by activation of NF- $\mathrm{KB}$ that is reactivated by IL-1 $\beta$. NF-אB induces the expression of genes responsible for the MAPK, COX2, and Tyrosine kinase pathways to finally activate the MMP1, 3 signaling at the injured tissue

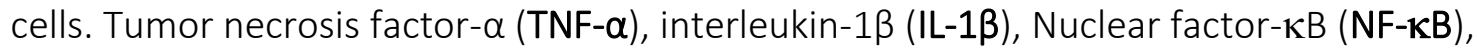
Mitogen-activated protein kinase (MAPK), Cyclooxegenase-2 (COX2), Matrix metalloproteinases (MMPs1, 3) 1 and 3 [129].

\subsection{RIOM GRADING AND SCORING SCALES}

There have been more than one grading scale for RIOM. Table.2.6.1 is comparing different RIOM scoring scales. [8, 124, 131, 132]. 


\begin{tabular}{|c|c|c|c|c|c|}
\hline Grade & 0 & 1 & 2 & 3 & 4 \\
\hline $\mathrm{WHO}$ & None & $\begin{array}{l}\text { Soreness } \\
\pm \text { erythema }\end{array}$ & $\begin{array}{l}\text { Erythema, } \\
\text { ulcers, and } \\
\text { patient can } \\
\text { swallow } \\
\text { solid food }\end{array}$ & $\begin{array}{l}\text { Ulcers with } \\
\text { extensive } \\
\text { erythema } \\
\text { and patient } \\
\text { cannot } \\
\text { swallow } \\
\text { solid food }\end{array}$ & $\begin{array}{l}\text { Mucositis } \\
\text { to the extent } \\
\text { that alimentation } \\
\text { is not possible }\end{array}$ \\
\hline RTOG & None & $\begin{array}{l}\text { Erythema } \\
\text { of the } \\
\text { mucosa }\end{array}$ & $\begin{array}{l}\text { Patchy } \\
\text { reaction } \\
<1.5 \mathrm{~cm} \text {, } \\
\text { noncontiguous }\end{array}$ & $\begin{array}{l}\text { Confluent } \\
\text { reaction } \\
>1.5 \mathrm{~cm}, \\
\text { contiguous }\end{array}$ & $\begin{array}{l}\text { Necrosis or } \\
\text { deep } \\
\text { ulceration, } \\
\pm \text { bleeding }\end{array}$ \\
\hline WCCNR & $\begin{array}{l}\text { Lesions: } \\
\text { none } \\
\text { Color: } \\
\text { pink } \\
\text { Bleeding: } \\
\text { none }\end{array}$ & $\begin{array}{l}\text { Lesions: } \\
1-4 \\
\text { Color: } \\
\text { slight red } \\
\\
\text { Bleeding: } \\
\text { N/A }\end{array}$ & $\begin{array}{l}\text { Lesions: } \\
>4 \\
\text { Color: } \\
\text { moderate red } \\
\text { Bleeding: } \\
\text { spontaneous }\end{array}$ & $\begin{array}{l}\text { Lesions: } \\
\text { coalescing } \\
\text { Color: } \\
\text { very red } \\
\text { Bleeding: } \\
\text { spontaneous }\end{array}$ & $\mathrm{N} / \mathrm{A}$ \\
\hline
\end{tabular}

Table.2.6.1: Comparison of OM scoring scales

WHO $=$ World Health Organization, RTOG = Radiation Therapy Oncology Group; WCCNR = Western Consortium for Cancer Nursing Research [8, 124, 131, 132].

The WHO Oral Toxicity Scale measures the anatomical, symptomatic, and functional elements of OM. While, the RTOG Acute Radiation Morbidity Scoring Criteria is for mucous membranes. Finally, the WCCNR describes only the anatomical changes associated with OM [133].

RTOG developed the Acute Radiation Morbidity Scoring Criteria for the evaluation of RT effects (another criteria was generated for late effects of RT) [134]. The National Cancer Institute ( $\mathrm{NCl}$ ) Common Toxicity Criteria (NCI-CTC) scores CT-related side 
effects. The RTOG was gathered with the NCI-CTC to produce version 2.0, which has been used in all NCl clinical trials since March 1998 (Table.2.6.2) [4, 134, 135]. The Oral Mucositis Index (OMI) scores the severity of OM by the erythema, ulceration, atrophy, and edema (a scale of 0 to 3 was designed for each element: 0 $=$ none, and $3=$ severe $)$. The OMI is considered internally consistent with high test retest and inter-scorer reliability, and it shows solid validity [136].

The Oral Mucositis Assessment Scale (OMAS) is highly reproducible between scorers, responsive over time, and accurate in detecting OM-associated elements [134]. OMAS records the objective assessment of OM depending on scoring the presence and size of ulcerations or pseudo-membranes (score 0 to 3: $0=$ no lesion; $1=$ lesion $<1 \mathrm{~cm}^{2} ; 2=$ lesion of $1 \mathrm{~cm}^{2}$ to $3 \mathrm{~cm}^{2} ; 3=$ lesion $>3 \mathrm{~cm}^{2}$ ) and erythema (score 0 to $2: 0=$ none; 1 = not severe; 2 = severe) on the upper and lower lips, right and left cheeks, right and left ventral and lateral tongue, floor of the mouth, soft palate, and hard palate $[132,137]$.

All these scoring scales are validated and are required in assessing RIOM and the therapeutic benefits of any new treatment of RIOM. 


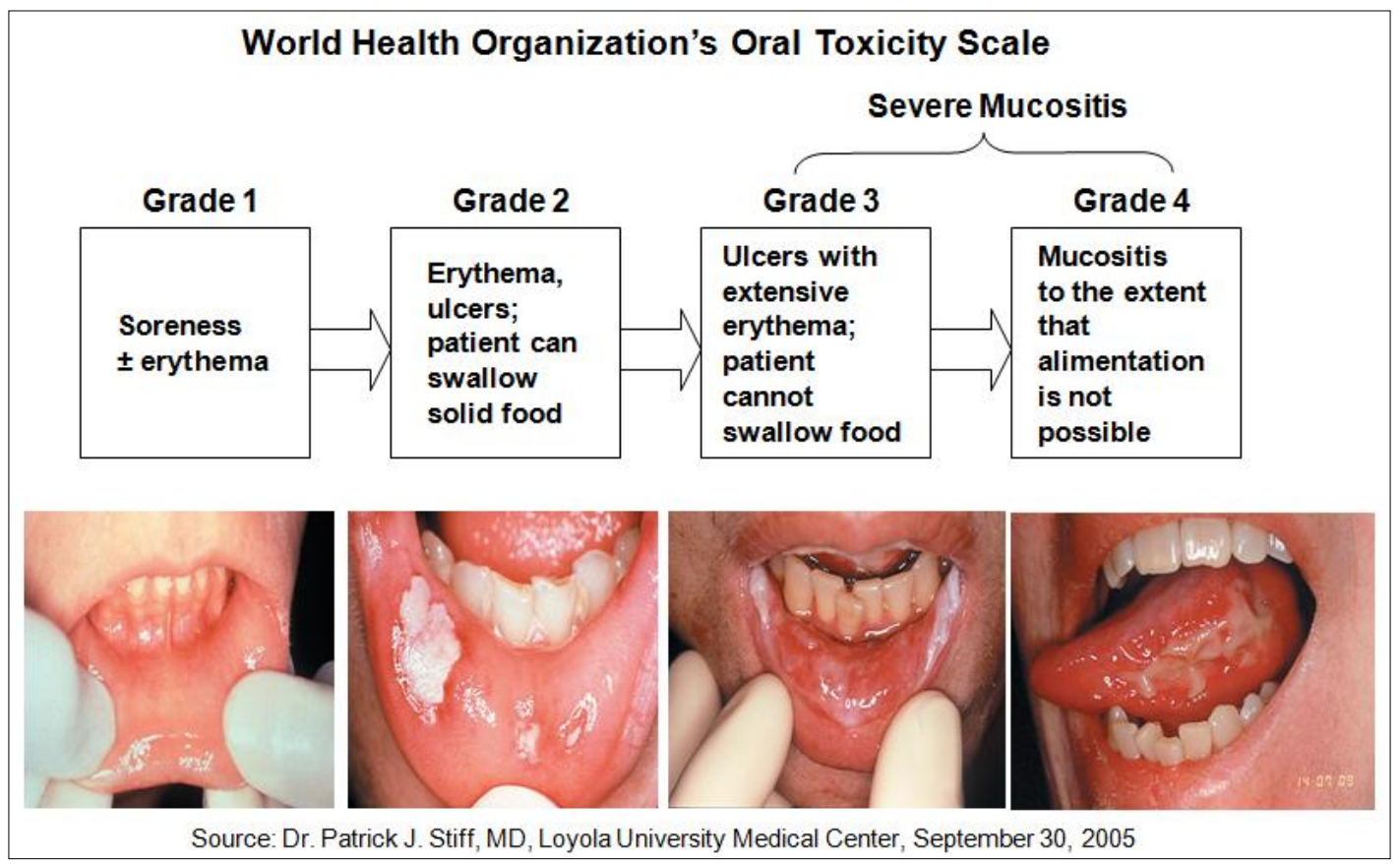

Figure.2.6.1: World Health Organization's Oral Toxicity Scale

\begin{tabular}{|c|c|c|c|c|c|}
\hline Side effect & $\begin{array}{l}\text { Grade } 0 \\
\text { (none) }\end{array}$ & $\begin{array}{c}\text { Grade } 1 \\
\text { (mild) }\end{array}$ & $\begin{array}{c}\text { Grade } 2 \\
\text { (moderate) }\end{array}$ & $\begin{array}{l}\text { Grade } 3 \\
\text { (severe) }\end{array}$ & $\begin{array}{c}\text { Grade } 4 \\
\text { (life threatening) }\end{array}$ \\
\hline $\begin{array}{l}\text { WHO } \\
\text { oral mucositis } \\
\text { (stomatitis) }\end{array}$ & none & $\begin{array}{l}\text { oral soreness, } \\
\text { erythema }\end{array}$ & $\begin{array}{l}\text { oral erythema, ulcers, } \\
\text { can eat solids }\end{array}$ & $\begin{array}{l}\text { oral ulcers, } \\
\text { requires liquid diet only }\end{array}$ & $\begin{array}{l}\text { oral alimentation } \\
\text { not possible }\end{array}$ \\
\hline $\begin{array}{l}\text { NCI-CTC } \\
\text { chemotherapy-induced } \\
\text { stomatitis/pharyngitis } \\
\text { (oral/pharyngeal } \\
\text { mucositis) }\end{array}$ & none & $\begin{array}{l}\text { painless ulcers, } \\
\text { erythema, or mild } \\
\text { soreness in the } \\
\text { absence of lesions }\end{array}$ & $\begin{array}{l}\text { painful erythema, edema, } \\
\text { or ulcers, but } \\
\text { can eat or swallow }\end{array}$ & $\begin{array}{l}\text { painful erythema, } \\
\text { edema, or ulcers } \\
\text { requiring IV hydration }\end{array}$ & $\begin{array}{l}\text { severe ulceration or } \\
\text { requires parenteral or } \\
\text { enteral nutritional } \\
\text { support or prophylactic } \\
\text { intubation }\end{array}$ \\
\hline $\begin{array}{l}\mathrm{NCl}-\mathrm{CTC} \\
\text { mucositis due to } \\
\text { radiation }\end{array}$ & none & $\begin{array}{l}\text { erythema of the } \\
\text { mucosa }\end{array}$ & $\begin{array}{l}\text { patchy pseudomembranous } \\
\text { reaction (patches } \\
\text { generally } \leq 1.5 \mathrm{~cm} \text { in } \\
\text { diameter and } \\
\text { noncontiguous) }\end{array}$ & $\begin{array}{l}\text { confluent pseudomembranous } \\
\text { reaction (contiguous patches } \\
\text { generally }>1.5 \mathrm{~cm} \text { in } \\
\text { diameter) }\end{array}$ & $\begin{array}{l}\text { necrosis or deep } \\
\text { ulceration; may include } \\
\text { bleeding not induced } \\
\text { by minor trauma } \\
\text { or abrasion }\end{array}$ \\
\hline $\begin{array}{l}\text { NCI-CTC } \\
\text { stomatitis/pharyngitis } \\
\text { (oral/pharyngeal mucositis) } \\
\text { for BMT studies }\end{array}$ & s) & $\begin{array}{l}\text { painless ulcers, } \\
\text { erythema, or mild } \\
\text { soreness in the } \\
\text { absence of lesions }\end{array}$ & $\begin{array}{l}\text { painful erythema, } \\
\text { edema, or ulcers, but } \\
\text { can swallow }\end{array}$ & $\begin{array}{l}\text { painful erythema, edema, } \\
\text { or ulcers preventing } \\
\text { swallowing or requiring } \\
\text { hydration or parenteral } \\
\text { (or enteral) nutritional } \\
\text { support }\end{array}$ & $\begin{array}{l}\text { severe ulceration } \\
\text { requiring prophylactic } \\
\text { intubation or resulting in } \\
\text { documented aspiration } \\
\text { pneumonia }\end{array}$ \\
\hline
\end{tabular}

Table.2.6.2: Toxicity grading of oral mucositis according to WHO and NCI-CTC criteria [4] 


\subsection{DIAGNOSIS OF RIOM}

RIOM can develop 2 weeks after the beginning of RT. Oral assessment guide (OAG) could be a useful tool for detection of early OM (Table.2.7.1) [3]. Apart from the early clinical signs and symptoms; $\mathrm{CBC}$ with differential is considered the baseline to help radiation oncologists to determine the most susceptible time for developing OM or oral infection. Radiation oncologists can start the RT as long as there is no evidence of any periodontal disease. If, at any point of the RT, RIOM develops, oral lesion culture and antimicrobial therapy are recommended as soon as possible. Since renal diseases are considered contributing factors for oral mucositis [125], chemistry levels should be regularly monitored by the treating physician [138].

\begin{tabular}{|c|c|c|c|}
\hline & 1 & 2 & 3 \\
\hline Voice & Normal & Deeper or raspy & Difficulty talking \\
\hline Swallow & Normal & Some pain & Unable to swallow \\
\hline Lips & Smooth pink \& moist & Dry or cracked & Ulcerated or bleeding \\
\hline Tongue & Pink \& moist & Coated $\&$ shiny \pm red & Blistered or cracked \\
\hline Saliva & Watery & Thick & Absent \\
\hline Mucous membranes & Pink \& moist & Red \& coated without ulcers & Ulcers \\
\hline Gingivae & Pink \& firm & Edematous $+/-$ redness & Spontaneous or pressure-induced bleeding \\
\hline Teeth/denture areas & Clean, no debris & Plaque \& localized debris & Generalized plaque or debris \\
\hline
\end{tabular}

Table.2.7.1: Oral assessment guide (OAG) [139]

\subsection{DIFFERENTIAL DIAGNOSIS OF RIOM}

Because similar conditions can coexist in immunocompromised patients including cancer patients on RT and/or CT, differential diagnosis for RIOM is critical. Here is a table for possible similar conditions (Figure.2.8.1) (Table.2.8.1) [3, 44]. 


\begin{tabular}{|c|c|c|c|c|}
\hline Disease/Injury & Cause & $\begin{array}{c}\text { Clinical } \\
\text { Presentation/Lab } \\
\text { Findings }\end{array}$ & Severity & $\begin{array}{l}\text { Treatment } \\
\text { Options }\end{array}$ \\
\hline Oral mucositis & $\begin{array}{l}\text { Chemotherapy } \\
\text { and radiation } \\
\text { therapy }\end{array}$ & $\begin{array}{l}\text { Diffuse redness, } \\
\text { ulcerations, and } \\
\text { pain, particularly in } \\
\text { areas where teeth } \\
\text { abut tissue }\end{array}$ & $\begin{array}{l}\text { Varies; in } \\
\text { BMT } \\
\text { setting up } \\
\text { to } 98 \% \\
\text { have Grade } \\
3 / 4\end{array}$ & $\begin{array}{l}\text { Palliative } \\
\text { rinses, } \\
\text { narcotics, } \\
\text { palifermin in } \\
\text { the BMT } \\
\text { setting }\end{array}$ \\
\hline $\begin{array}{l}\text { Aphthous } \\
\text { stomatitis }\end{array}$ & $\begin{array}{l}\text { Etiology not } \\
\text { identified }\end{array}$ & Single painful ulcer & $\begin{array}{l}\text { Localized, } \\
\text { but painful; } \\
\text { maximum } \\
\text { grade } 2\end{array}$ & Topical \\
\hline $\begin{array}{l}\text { Herpetic } \\
\text { mucositis }\end{array}$ & HSV1 & $\begin{array}{l}\text { Usually several } \\
\text { spots; ulcerative }\end{array}$ & $\begin{array}{l}\text { Usually } \\
\text { grade 1-2 }\end{array}$ & $\begin{array}{l}\text { Acyclovir, } \\
\text { valacyclovir, } \\
\text { foscarnet }\end{array}$ \\
\hline Oral thrush & Candida & $\begin{array}{l}\text { Varies from } \\
\text { painless to mild } \\
\text { soreness; whitish } \\
\text { plaques }\end{array}$ & $\begin{array}{l}\text { Usually } \\
\text { grade } 0-1\end{array}$ & $\begin{array}{l}\text { Nystatin } \\
\text { rinses; } \\
\text { fluconazole } \\
\text { and other } \\
\text { azoles }\end{array}$ \\
\hline $\begin{array}{l}\text { Denture/oral } \\
\text { trauma }\end{array}$ & Dentures & $\begin{array}{l}\text { Common in elderly } \\
\text { patients with loose- } \\
\text { fitting dentures }\end{array}$ & $\begin{array}{l}\text { Can limit } \\
\text { calories }\end{array}$ & $\begin{array}{l}\text { Repair, } \\
\text { removal of } \\
\text { dentures }\end{array}$ \\
\hline $\begin{array}{l}\text { Gangrenous } \\
\text { stomatitis }\end{array}$ & $\begin{array}{l}\text { Bacterial } \\
\text { infections }\end{array}$ & $\begin{array}{l}\text { Necrotic } \\
\text { pseudomembranes }\end{array}$ & $\begin{array}{l}\text { Rare, can } \\
\text { be severe }\end{array}$ & $\begin{array}{l}\text { Antibacterials } \\
\text { that treat oral } \\
\text { aerobes and } \\
\text { anaerobes }\end{array}$ \\
\hline $\begin{array}{l}\text { Acute } \\
\text { necrotizing } \\
\text { stomatitis }\end{array}$ & $\begin{array}{l}\text { Bacterial } \\
\text { infections in } \\
\text { immune } \\
\text { deficient } \\
\text { patients }\end{array}$ & $\begin{array}{l}\text { Pain, fever, } \\
\text { necrotic, bloody } \\
\text { ulcers }\end{array}$ & Grade 3/4 & $\begin{array}{l}\text { Control of } \\
\text { infection }\end{array}$ \\
\hline
\end{tabular}

Table.2.8.1: Differential diagnosis of RIOM [3, 44]. BMT = Bone Marrow transplantation. 


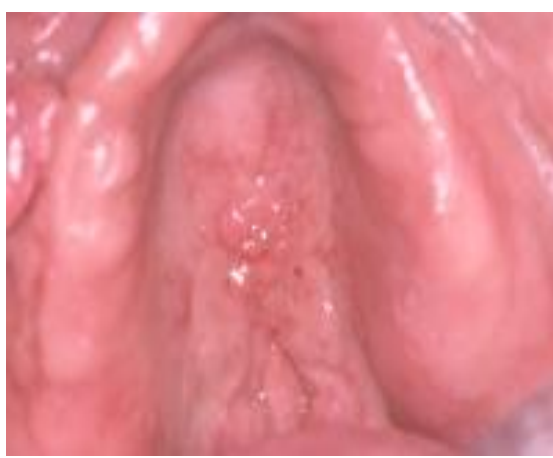

Oral Thrush

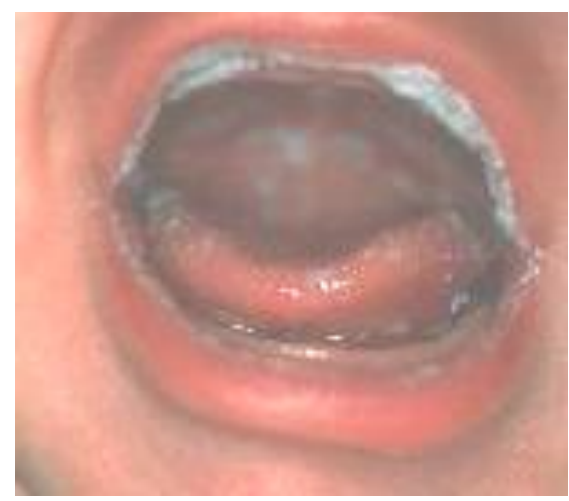

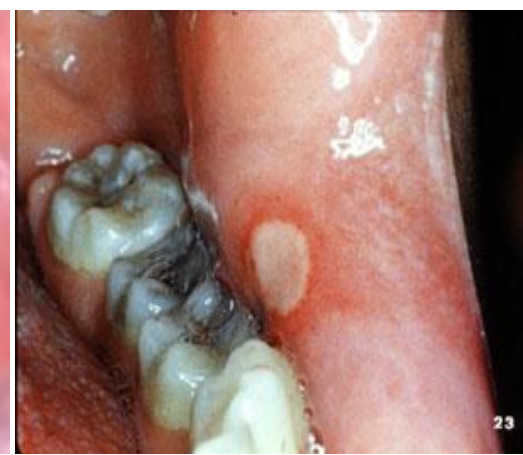

Oral Mucositis*

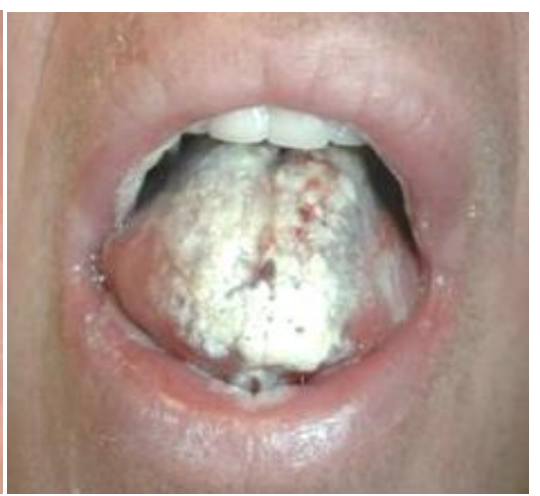

Figure.2.8.1: Differential diagnosis of RIOM from similar and/or accompanying conditions

RIOM should be well differentiated from local denture-related lesion, aphthus ulcer, and oral thrush in order to use the proper management for each lesion. Images were provided from Dr. Patrick J. Stiff, MD, Layola University Medical Center, September 30 ${ }^{\text {th }}, 2005 .{ }^{*}$ Image from:

Spielberger, Ricardo; Kepivance ${ }^{\mathrm{TM}}$ : A Breakthrough for Oral Mucositis Associated with Myeloablative Hematopoietic Stem Cell Transplantation; City of Hope National Medical Center, Department of Hematology and Bone Marrow Transplantation.

\subsection{PROGNOSIS OF RIOM}

The general long-term prognosis is reasonably good since most lesions resolve within 2-4 weeks after stopping RT or CT. Although RIOM is considered a selflimited injury in some patients, it could be a lethal injury in moderately to severely ill 
patients, which could lead to ICU admission with obligatory cessation of RT. Patient losses are a common event at these circumstances [140].

\subsection{RIOM PREVENTION}

Symptomatic management and complications prevention; e.g. nutritional support, pain control, and prophylaxis and/or treatment of secondary infections are considered the main cornerstone in the management of RIOM.

Maintaining good oral care is the main preventive measure for RIOM in order to minimize the risk for candidiasis or secondary bacterial infection, especially in hyperfractionated radiotherapy, combined chemo-radiation regimens, or radiotherapy combined with a targeted agent due to increased mucositis severity [115].

Good oral hygiene includes [3]:

1- Rinsing with a non-irritating solution e.g. saline to increase the quality of saliva.

2- Ultra-soft tooth brushing with fluoride toothpaste on a daily basis.

3- Scaling and cleaning.

4- Very soft diet with low sugar, and non-acidic food and drinks (Table.2.10.1).

5- Flossing is not recommended due to low platelet count.

6- Minimize denture use.

7- No smoking or alcohol. 


\begin{tabular}{|lll|}
\hline $\begin{array}{l}\text { Diet that is } \\
\text { typically acceptable }\end{array}$ & \multicolumn{1}{c}{ Things to avoid } & $\begin{array}{c}\text { Habits } \\
\text { to avoid }\end{array}$ \\
\hline Liquids & Rough food (potato chips, crisps, toast) & Smoking \\
Purees & Spices & Alcohol \\
Ice & Salt & \\
Custards & Acidic fruit (grapefruit, lemon, orange) & \\
Nonacidic fruits (banana, mango, melon, & & \\
peach) & & \\
Soft cheeses & & \\
Eggs & & \\
\hline
\end{tabular}

Table.2.10.1: Diet recommended for RIOM patients [3]

Other preventive procedures include minimizing the microbial load and educating the patient on good oral hygiene which is mandatory. Cryotherapy, keratinocyte growth factor-1 (KGF-1), low-level laser therapy, benzydamine mouthwash, and zinc were also applied. (Table.2.10.2) [115].

\begin{tabular}{|c|c|c|c|}
\hline $\begin{array}{l}\text { Intervention/mode of } \\
\text { administration }\end{array}$ & Purpose & Cancer treatment & $\begin{array}{l}\text { Level of } \\
\text { evidence }\end{array}$ \\
\hline \multicolumn{4}{|c|}{$\begin{array}{l}\text { Recommendations IN FAVOR of an intervention (strong evidence supports } \\
\text { effectiveness in the treatment setting listed): }\end{array}$} \\
\hline Oral cryotherapy for 30 minutes & $\begin{array}{l}\text { Prevention } \\
\text { of OM }\end{array}$ & $\begin{array}{l}\text { Patients receiving } \\
\text { bolus } 5 \text {-fluorouracil } \\
\text { chemotherapy }\end{array}$ & Level II \\
\hline $\begin{array}{l}\text { Recombinant human keratinocyte } \\
\text { growth factor- } 1 \\
\text { (palifermin) at a dose of } 60 \mu \mathrm{g} / \mathrm{kg} \\
\text { per day for } 3 \text { days prior to } \\
\text { conditioning treatment and for } \\
3 \text { days after transplant }\end{array}$ & $\begin{array}{l}\text { Prevention } \\
\text { of OM }\end{array}$ & $\begin{array}{l}\text { Patients receiving } \\
\text { high-dose } \\
\text { chemotherapy and } \\
\text { TBI, followed by } \\
\text { autologous stem } \\
\text { cell transplantation, } \\
\text { for a hematological } \\
\text { malignancy }\end{array}$ & Level II \\
\hline $\begin{array}{l}\text { Low-level laser therapy (wavelength } \\
\text { at } 650 \mathrm{~nm} \text {, } \\
\text { power of } 40 \mathrm{~mW} \text {, and each square } \\
\text { centimeter } \\
\text { treated with the required time to a } \\
\text { tissue energy } \\
\text { dose of } 2 \mathrm{~J} / \mathrm{cm} 2 \text { ) }\end{array}$ & $\begin{array}{l}\text { Prevention } \\
\text { of OM }\end{array}$ & $\begin{array}{l}\text { Patients receiving } \\
\text { HSCT conditioned } \\
\text { with high-dose } \\
\text { chemotherapy, with } \\
\text { or without TBI }\end{array}$ & Level II \\
\hline $\begin{array}{l}\text { Patient-controlled analgesia with } \\
\text { morphine }\end{array}$ & $\begin{array}{l}\text { Pain } \\
\text { reduction }\end{array}$ & $\begin{array}{l}\text { Patients } \\
\text { undergoing HSCT }\end{array}$ & Level II \\
\hline
\end{tabular}




\begin{tabular}{|c|c|c|c|}
\hline Benzydamine mouthwash & $\begin{array}{l}\text { Prevention } \\
\text { of } \\
\text { OM }\end{array}$ & $\begin{array}{l}\text { Patients with HNC } \\
\text { receiving moderate } \\
\text { dose radiation } \\
\text { therapy (up to } 50 \\
\text { Gy), without } \\
\text { concomitant } \\
\text { chemotherapy }\end{array}$ & Level II \\
\hline \multicolumn{4}{|c|}{$\begin{array}{l}\text { Suggestions IN FAVOR of an intervention (weaker evidence supports } \\
\text { effectiveness in the treatment setting listed): }\end{array}$} \\
\hline Oral care protocols & $\begin{array}{l}\text { Prevention } \\
\text { of } \\
\text { OM }\end{array}$ & $\begin{array}{l}\text { All age groups and } \\
\text { across all cancer } \\
\text { treatment } \\
\text { modalities }\end{array}$ & Level III \\
\hline Oral cryotherapy & $\begin{array}{l}\text { Prevention } \\
\text { of } \\
\text { OM }\end{array}$ & $\begin{array}{l}\text { Patients receiving } \\
\text { high-dose } \\
\text { melphalan, with or } \\
\text { without } \\
\text { TBI, as } \\
\text { conditioning for } \\
\text { HSCT }\end{array}$ & Level III \\
\hline $\begin{array}{l}\text { Low-level laser therapy (wavelength } \\
\text { around } 632.8 \mathrm{~nm} \text { ) }\end{array}$ & $\begin{array}{l}\text { Prevention } \\
\text { of } \\
\text { OM }\end{array}$ & $\begin{array}{l}\text { Patients } \\
\text { undergoing } \\
\text { radiotherapy, } \\
\text { without } \\
\text { concomitant } \\
\text { chemotherapy, for } \\
\text { HNC }\end{array}$ & Level III \\
\hline Transdermal fentanyl & $\begin{array}{l}\text { Pain } \\
\text { reduction }\end{array}$ & $\begin{array}{l}\text { Patients receiving } \\
\text { conventional or } \\
\text { high-dose } \\
\text { chemotherapy, } \\
\text { with or without TBI }\end{array}$ & Level III \\
\hline $2 \%$ morphine mouthwash & $\begin{array}{l}\text { Pain } \\
\text { reduction }\end{array}$ & $\begin{array}{l}\text { Patients receiving } \\
\text { chemo-radiation for } \\
\text { HNC }\end{array}$ & Level III \\
\hline $0.5 \%$ doxepin mouthwash & $\begin{array}{l}\text { Pain } \\
\text { reduction }\end{array}$ & $\begin{array}{l}\text { All patients with } \\
\text { OM-induced pain }\end{array}$ & Level IV \\
\hline $\begin{array}{l}\text { Systemic zinc supplements } \\
\text { administered orally }\end{array}$ & $\begin{array}{l}\text { Prevention } \\
\text { of } \\
\text { OM }\end{array}$ & $\begin{array}{l}\text { HNC patients } \\
\text { receiving radiation } \\
\text { therapy or chemo- } \\
\text { radiation }\end{array}$ & Level III \\
\hline \multicolumn{4}{|c|}{$\begin{array}{l}\text { Recommendations AGAINST interventions (strong evidence indicates lack } \\
\text { of effectiveness in the treatment setting listed): }\end{array}$} \\
\hline $\begin{array}{l}\text { PTA (polymyxin, tobramycin, } \\
\text { amphotericin B) and BCoG }\end{array}$ & $\begin{array}{l}\text { Prevention } \\
\text { of } \\
\text { OM }\end{array}$ & $\begin{array}{l}\text { Patients receiving } \\
\text { radiation therapy } \\
\text { for HNC }\end{array}$ & Level II \\
\hline
\end{tabular}




\begin{tabular}{|c|c|c|c|}
\hline $\begin{array}{l}\text { (bacitracin, clotrimazole, } \\
\text { gentamicin) }\end{array}$ & & & \\
\hline Iseganan antimicrobial mouthwash & $\begin{array}{l}\text { Prevention } \\
\text { of } \\
\mathrm{OM}\end{array}$ & $\begin{array}{l}\text { Patients receiving } \\
\text { high-dose } \\
\text { chemotherapy, with } \\
\text { or without TBI, for } \\
\text { HSCT or in patients } \\
\text { receiving } \\
\text { radiation therapy or } \\
\text { concomitant } \\
\text { chemo-radiation for } \\
\text { HNC }\end{array}$ & Level II \\
\hline Iseganan antimicrobial mouthwash & $\begin{array}{l}\text { Prevention } \\
\text { of } \\
\text { OM }\end{array}$ & $\begin{array}{l}\text { Patients receiving } \\
\text { high-dose } \\
\text { chemotherapy, with } \\
\text { or without TBI, for } \\
\text { HSCT or in patients } \\
\text { receiving } \\
\text { radiation therapy or } \\
\text { concomitant } \\
\text { chemo-radiation for } \\
\text { HNC }\end{array}$ & Level II \\
\hline Sucralfate mouthwash & $\begin{array}{l}\text { Prevention } \\
\text { of } \\
\mathrm{OM}\end{array}$ & $\begin{array}{l}\text { Patients receiving } \\
\text { chemotherapy for } \\
\text { cancer (I), or } \\
\text { inpatients } \\
\text { receiving radiation } \\
\text { therapy (I) or } \\
\text { concomitant } \\
\text { chemo-radiation (II) } \\
\text { for HNC }\end{array}$ & Level I, II \\
\hline Sucralfate mouthwash & $\begin{array}{l}\text { Treatment } \\
\text { of } \\
\text { OM }\end{array}$ & $\begin{array}{l}\text { Patients receiving } \\
\text { chemotherapy for } \\
\text { cancer (I), or in } \\
\text { patients receiving } \\
\text { radiation therapy } \\
\text { (II) for HNC }\end{array}$ & Level I, II \\
\hline Intravenous glutamine & $\begin{array}{l}\text { Prevention } \\
\text { of } \\
\text { OM }\end{array}$ & $\begin{array}{l}\text { Patients receiving } \\
\text { high-dose } \\
\text { chemotherapy, with } \\
\text { or without TBI, for } \\
\text { HSCT }\end{array}$ & Level II \\
\hline
\end{tabular}




\begin{tabular}{|l|l|l|l|}
\hline Chlorhexidine mouthwash & $\begin{array}{l}\text { Prevention } \\
\text { of } \\
\text { OM }\end{array}$ & $\begin{array}{l}\text { Patients receiving } \\
\text { radiation therapy } \\
\text { for HNC }\end{array}$ & Level III \\
\hline $\begin{array}{l}\text { Granulocyte-macrophage-colony- } \\
\text { stimulating factor } \\
\text { mouthwash }\end{array}$ & $\begin{array}{l}\text { Prevention } \\
\text { of } \\
\text { OM }\end{array}$ & $\begin{array}{l}\text { Patients receiving } \\
\text { high-dose } \\
\text { chemotherapy, for } \\
\text { autologous or } \\
\text { allogeneic HSCT }\end{array}$ & Level II \\
\hline Misoprostol mouthwash & $\begin{array}{l}\text { Prevention } \\
\text { of } \\
\text { OM }\end{array}$ & $\begin{array}{l}\text { Patients receiving } \\
\text { radiation therapy } \\
\text { for HNC }\end{array}$ & Level III \\
\hline $\begin{array}{l}\text { Systemic pentoxifylline, } \\
\text { administered orally }\end{array}$ & $\begin{array}{l}\text { Prevention } \\
\text { of } \\
\text { OM }\end{array}$ & $\begin{array}{l}\text { Patients } \\
\text { undergoing HSCT }\end{array}$ & Level III \\
\hline $\begin{array}{l}\text { Systemic pilocarpine, administered } \\
\text { orally }\end{array}$ & $\begin{array}{l}\text { Prevention } \\
\text { of } \\
\text { OM }\end{array}$ & $\begin{array}{l}\text { Patients receiving } \\
\text { radiation therapy } \\
\text { for Head and Neck } \\
\text { cancer (III), or } \\
\text { patients receiving } \\
\text { high-dose } \\
\text { chemotherapy, } \\
\text { with or without TBI, } \\
\text { for HSCT (II) }\end{array}$ & Level \\
IIIII \\
\hline
\end{tabular}

Table.2.10.2 Multinational Association for Supportive Care in Cancer/International Society for Oral Oncology (MASCC/ISOO) Clinical Practice Guidelines for Oral Mucositis [115] $\mathrm{OM}=$ oral mucositis $\mu \mathrm{g}=$ microgram, $\mathrm{kg}=$ kilogram, $\mathrm{nm}=$ nanometer, $\mathrm{mW}=$ milliwatt, $\mathrm{J}=$ Joule, $\mathrm{cm}=$ centimeter, $\mathrm{Gy}=\mathrm{Gray}, \mathrm{HSCT}=$ hematopoietic stem cell transplantation, $\mathrm{TBI}=$ total body irradiation, $\mathrm{HNC}=$ Head and Neck cancer.

\subsection{RIOM TREATMENT}

Many therapeutic agents and procedures were followed in treating RIOM. We will try to summarize them as follows. 


\section{Mechanistically based mucositis interventions in preclinical or clinical development [126]:}

A- L-glutamine counteracts treatment-induced metabolic deficiencies.

B- Amifostine (Free-radical scavenger) reduces pro-inflammatory-cytokine production.

C- Benzydamine $\mathrm{HCl}$ reduces pro-inflammatory-cytokine production; scavenges reactive oxygen species membrane stabilization; antimicrobial.

D- $\mathrm{N}$-acetylcysteine antioxidant suppresses NF-kB activation.

E- Keratinocyte growth factor is an epithelial mitogen that reduces levels of reactive oxygen species by activating NRF2, [nuclear factor (erythroid-derived 2)-like 2].

F- Sphingomyelinase and ceramide synthase inhibit ceramide-pathway-induced apoptosis inhibitors.

G- Manganese superoxide dismutase detoxifies reactive oxygen species.

H- COX2 inhibitors suppress NF-кB; reduce pro-inflammatory-cytokine production; inhibit angiogenesis.

\section{Established methods [4]}

A- Locally applied nonpharmacological methods

1- Oral Hygiene as before.

2- Honey [10-12].

B- Locally applied pharmacotherapeutics

1- Antimicrobial agents.

2- Antifungal agents. 
3- Antiviral agents.

4- Antibacterial agents.

5- Local anesthetics.

\section{Experimental approaches [4]}

A- Locally applied nonpharmacological methods.

1- Radiation shields, midline mucosa-sparing blocks.

2- Laser, low-energy helium-neon lasers.

3- Chamomile, in emulsion (anti-inflammatory).

4- Benzydamine, non-steroidal, antimicrobal, anti-inflammatory, anesthetic, and analgesic effect

5- Sucralfate, basic aluminium salt of sucrose sulfate.

6- Prostaglandin E2.

7- Retinoids, vitamin $\mathrm{A}$ and its derivatives

8- Vitamin E.

9- Sodium alginate.

10-Glutamine, non-steroidal amino acid with protective effect

B- Cytokines

1- Transforming growth factor- $\beta 3$, inhibits oral basal cell proliferation.

2- Colony-stimulating factor (G-CSF, filgrastim) and granulocyte-macrophage colony-stimulating factor (GM-CSF, molgramostim) systemic therapy recruited neutrophils to the injury site.

C- Antiseptic agents

1- Povidone-iodine, antiviral, antibacterial, and antifungal agent. 
2- Capsaicin, neutrophils inhibitor decreased the pain.

D- Systemically applied pharmacotherapeutics

1- G-CSF and GM-CSF.

2- Amifostine, antioxidant cytoprotective agent.

3- Beta-carotene.

4- Azelastine, anti-inflammatory, antioxidant and antihistamine

5- Propantheline, an anticholinergic agent that reduces salivary flow.

6- Immunoglobulins.

\section{Inefficacious approaches [4]}

A- Locally applied pharmacotherapeutics

1- Allopurinol and Uridine.

2- Chlorhexidine, bisguanidine exhibiting broad-spectrum antibacterial and antimycotic activity.

3- Hydrogen peroxide.

B- Systemically applied pharmacotherapeutics

1- Pentoxifylline, regulates endotoxin-induced production of TNF- $\alpha$ [4].

\subsection{CELLULAR THERAPIES FOR RIOM}

Bone marrow-derived mesynchymal stromal cells (bmMSCs) therapy have been applied in fractionated radiation-induced oral mucositis where the administration of a systemic single dose of 6 million MSCs resulted in a significant decrease in ED50 (the RT dose that produces ulcer in $50 \%$ of irradiated mice) [141]. The first MSCs therapy for RIOM was done in 2014 by Schmidt et al [48]. They concluded that transplantation 
of bone marrow (BM) or bmMSCs could modulate RIOM in fractionated RT, depending on the time of transplantation [48]. Nevertheless, in another study, these authors also concluded that bmMSCs transplantation had no therapeutic benefits on RIOM in single dose RT when compared to the therapeutic effect of mobilization of endogenous BM stem cells [72]. More studies are needed in the field since the initial studies showed significant clinically relevant therapeutic effects of MSCs therapy for RIOM.

\subsubsection{Clinical trial for RIOM}

Table.2.12.1.1 summarizes the clinical trials that have been done until 2001 for prevention $(\mathrm{P})$ and treatment $(\mathrm{T})$ of RIOM [4]. This followed by the current clinical trials summarized in Table.2.12.1.2.

\begin{tabular}{|l|l|l|l|l|l|}
\hline Injury & Author & $\begin{array}{l}\text { Randomized/ } \\
\text { Controlled/ } \\
\text { Double blind }\end{array}$ & $\begin{array}{l}\text { P } \\
\text { T }\end{array}$ & Application/Doses & Results \\
\hline RT & $\begin{array}{l}\text { Scherlacher } \\
\text { et al. }\end{array}$ & yes/yes/no & P & $\begin{array}{l}\text { Sucralfate vs. } \\
\text { standard oral } \\
\text { hygiene }\end{array}$ & $\begin{array}{l}\text { Significant reduction } \\
\text { of incidence and } \\
\text { severity of mucositis }\end{array}$ \\
\hline RT & Allison et al. & yes/yes/no & $\begin{array}{l}\text { P } \\
+\begin{array}{l}\text { sucralfate+ } \\
\text { fluconazole vs. } \\
\text { standard oral care }\end{array}\end{array}$ & $\begin{array}{l}\text { significant reduced } \\
\text { severity and } \\
\text { symptomatic relief }\end{array}$ \\
\hline RT & Franzen et al. & yes/yes/yes & P & $\begin{array}{l}\text { sucralfate vs. } \\
\text { placebo }\end{array}$ & $\begin{array}{l}\text { sig. lower incidence } \\
\text { of severe mucositis }\end{array}$ \\
\hline RT & $\begin{array}{l}\text { Makkonen et } \\
\text { al. }\end{array}$ & yes/yes/yes & P & $\begin{array}{l}\text { sucralfate vs. } \\
\text { placebo }\end{array}$ & $\begin{array}{l}\text { only slight protective } \\
\text { effect of sucralfate }\end{array}$ \\
\hline RT & Epstein et al. & yes/yes/yes & $\begin{array}{l}\text { Placralfate vs. } \\
+ \\
\text { T }\end{array}$ & $\begin{array}{l}\text { nonsignificant } \\
\text { reduction of oral } \\
\text { placebo }\end{array}$ \\
\hline RT & $\begin{array}{l}\text { Meredith et } \\
\text { al. }\end{array}$ & yes/yes/yes & $\begin{array}{l}\text { T } \\
\text { antacid, } \\
\text { diphenhydramine, }\end{array}$ & $\begin{array}{l}\text { nonsignificant } \\
\text { reduction of severity }\end{array}$ \\
\hline
\end{tabular}




\begin{tabular}{|c|c|c|c|c|c|}
\hline & & & & $\begin{array}{l}\text { lidocaine } \pm \\
\text { sucralfate }\end{array}$ & \\
\hline RT & Cengiz et al. & yes/yes/yes & $\begin{array}{l}\mathrm{P} \\
+ \\
\mathrm{T}\end{array}$ & $\begin{array}{l}\text { sucralfate vs. } \\
\text { placebo }\end{array}$ & decreased severity \\
\hline RT & Carter et al. & yes/yes/yes & $\mathrm{P}$ & $\begin{array}{l}\text { sucralfate vs. } \\
\text { placebo }\end{array}$ & no difference \\
\hline RT & Barker et al. & yes/yes/yes & $\begin{array}{l}\mathrm{P} \\
+ \\
\mathrm{T}\end{array}$ & $\begin{array}{l}\text { oral hygiene+ } \\
\text { sucralfate vs. } \\
\text { diphenhydramine+ } \\
\text { kaolin-pectin }\end{array}$ & no difference \\
\hline RT & Feber et al. & yes/yes/no & $\mathrm{P}$ & $\begin{array}{l}\text { hydrogen peroxide } \\
\text { vs. saline }\end{array}$ & $\begin{array}{l}\text { significantly more } \\
\text { oral discomfort }\end{array}$ \\
\hline RT & $\begin{array}{l}\text { Spijkervet et } \\
\text { al. }\end{array}$ & yes/yes/yes & $\begin{array}{l}\mathrm{P} \\
+ \\
\mathrm{T}\end{array}$ & $\begin{array}{l}\text { chlorhexidine vs. } \\
\text { placebo }\end{array}$ & no difference \\
\hline RT & Foote et al. & yes/yes/yes & $\begin{array}{l}\mathrm{P} \\
+ \\
\mathrm{T}\end{array}$ & $\begin{array}{l}\text { chlorhexidine vs. } \\
\text { placebo }\end{array}$ & slight aggravation \\
\hline $\begin{array}{l}\mathrm{HD}- \\
\mathrm{CT}+\mathrm{RT}\end{array}$ & Feretti et al. & yes/yes/yes & $\begin{array}{l}\mathrm{P} \\
+ \\
\mathrm{T}\end{array}$ & $\begin{array}{l}\text { chlorhexidine vs. } \\
\text { placebo }\end{array}$ & $\begin{array}{l}\text { significant reduction } \\
\text { of incidence and } \\
\text { severity in the CT } \\
\text { group only }\end{array}$ \\
\hline $\mathrm{CT}+\mathrm{RT}$ & Rahn et al. & yes/yes/no & $\mathrm{P}$ & $\begin{array}{l}\text { nystatin, rutosides, } \\
\text { immuno-globuines, } \\
\text { panthenol } \pm \text { PVP- } \\
\text { iodine }\end{array}$ & significant reduction \\
\hline $\mathrm{CT}+\mathrm{RT}$ & $\begin{array}{l}\text { Adamiez et } \\
\text { al. }\end{array}$ & yes/yes/no & $\mathrm{P}$ & $\begin{array}{l}\text { nystatin, rutosides, } \\
\text { immuno-globulines, } \\
\text { panthenol } \pm \text { PVP- } \\
\text { iodine }\end{array}$ & significant reduction \\
\hline $\mathrm{CT}+\mathrm{RT}$ & $\begin{array}{l}\text { Hasenau et } \\
\text { al. }\end{array}$ & no/yes/no & & $\begin{array}{l}\text { hydrogen peroxide, } \\
\text { PVP iodine, } \\
\text { dexpanthenol, } \\
\text { nystatin }\end{array}$ & $\begin{array}{l}\text { lower incidence and } \\
\text { severity of oral } \\
\text { mucositis }\end{array}$ \\
\hline RT & $\begin{array}{l}\text { Spijkervet et } \\
\text { al. }\end{array}$ & no/yes/no & & $\begin{array}{l}\text { lozenges of } \\
\text { polymyxin, } \\
\text { tobramycin, } \\
\text { amphotericin vs. } \\
\text { historical controls }\end{array}$ & $\begin{array}{l}\text { lower incidence of } \\
\text { mucositis }\end{array}$ \\
\hline RT & Mattews et al. & yes/yes/no & $\mathrm{P}$ & $\begin{array}{l}\text { sucralfate+ } \\
\text { (ciprofloxacin or } \\
\text { ampicillin)+ } \\
\text { clotrimazole vs. } \\
\text { sucralfate }\end{array}$ & $\begin{array}{l}\text { sig. reduction of } \\
\text { incidence and } \\
\text { severity }\end{array}$ \\
\hline
\end{tabular}




\begin{tabular}{|c|c|c|c|c|c|}
\hline RT & $\begin{array}{l}\text { Symonds et } \\
\text { al. }\end{array}$ & yes/yes/yes & & $\begin{array}{l}\text { pastilles containing } \\
\text { polymyxin, } \\
\text { tobramycin, } \\
\text { amphothericin vs. } \\
\text { placebo }\end{array}$ & $\begin{array}{l}\text { significant reduction } \\
\text { of severe mucositis }\end{array}$ \\
\hline RT & Okuno et al. & yes/yes/yes & $\begin{array}{l}\mathrm{P} \\
+ \\
\mathrm{T}\end{array}$ & $\begin{array}{l}\text { lozenges of } \\
\text { polymyxin, } \\
\text { tobramycin, } \\
\text { amphotericin vs. } \\
\text { placebo }\end{array}$ & $\begin{array}{l}\text { significant reduction } \\
\text { of oral discomfort, } \\
\text { no objective } \\
\text { difference }\end{array}$ \\
\hline RT & Okuno et al. & yes/yes/no & $\mathrm{T}$ & $\begin{array}{l}\text { amphotericin+ } \\
\text { colistin+ tobramycin } \\
\text { + chlorhexidine vs. } \\
\text { placebo }\end{array}$ & $\begin{array}{l}\text { decreased oral } \\
\text { discomfort }\end{array}$ \\
\hline RT & $\begin{array}{l}\text { Symonds et } \\
\text { al. }\end{array}$ & yes/yes/yes & $\mathrm{P}$ & $\begin{array}{l}\text { amphotericin+ } \\
\text { tobramycin+ } \\
\text { polymyxin vs. } \\
\text { placebo }\end{array}$ & $\begin{array}{l}\text { significant reduction } \\
\text { of the incidence of } \\
\text { severe mucositis }\end{array}$ \\
\hline RT & $\begin{array}{l}\text { Spijkervet et } \\
\text { al. }\end{array}$ & no/yes/no & $\mathrm{P}$ & $\begin{array}{l}\text { amphotericin+ } \\
\text { tobramycin+ } \\
\text { polymyxin vs. } \\
\text { historical } \\
\text { chlorhexidine or } \\
\text { placebo group }\end{array}$ & $\begin{array}{l}\text { significant reduction } \\
\text { of severity of } \\
\text { mucositis }\end{array}$ \\
\hline $\mathrm{RT}$ & Carl et al. & no/yes/no & $\begin{array}{l}\mathrm{P} \\
+ \\
\mathrm{T}\end{array}$ & $\begin{array}{l}\text { chamomile vs. } \\
\text { historical group }\end{array}$ & $\begin{array}{l}\text { low incidence of } \\
\text { mucositis }\end{array}$ \\
\hline RT & Fidler et al. & yes/yes/yes & $\mathrm{P}$ & $\begin{array}{l}\text { chamomile vs. } \\
\text { placebo, } \\
\text { cryoprophylaxis in } \\
\text { all patients }\end{array}$ & no difference \\
\hline RT & $\begin{array}{l}\text { Abdelaal et } \\
\text { al. }\end{array}$ & no/no/no & $\mathrm{P}$ & $\begin{array}{l}\text { high-dose } \\
\text { betamethasone }\end{array}$ & $\begin{array}{l}\text { impressive } \\
\text { prevention of } \\
\text { mucositis incidence }\end{array}$ \\
\hline $\mathrm{RT}$ & Kim et al. & yes/yes/yes & $\begin{array}{l}\mathrm{P} \\
+ \\
\mathrm{T}\end{array}$ & $\begin{array}{l}\text { benzydamine vs. } \\
\text { placebo }\end{array}$ & $\begin{array}{l}\text { significant reduction } \\
\text { (less pain) }\end{array}$ \\
\hline RT & Epstein et al. & yes/yes/yes & $\begin{array}{l}\mathrm{P} \\
+ \\
\mathrm{T}\end{array}$ & $\begin{array}{l}\text { benzydamine vs. } \\
\text { placebo }\end{array}$ & $\begin{array}{l}\text { significant reduction } \\
\text { of incidence and } \\
\text { severity }\end{array}$ \\
\hline RT & $\begin{array}{l}\text { Samaranayak } \\
\text { e et al. }\end{array}$ & yes/no/no & $\mathrm{P}$ & $\begin{array}{l}\text { benzydamine vs. } \\
\text { chlorhexidine }\end{array}$ & $\begin{array}{l}\text { no difference (more } \\
\text { discomfort) }\end{array}$ \\
\hline $\mathrm{CT}+\mathrm{RT}$ & Prada et al. & yes/yes/yes & $\begin{array}{l}\mathrm{P} \\
+ \\
\mathrm{T}\end{array}$ & $\begin{array}{l}\text { benzydamine vs. } \\
\text { placebo }\end{array}$ & significant reduction \\
\hline
\end{tabular}




\begin{tabular}{|c|c|c|c|c|c|}
\hline RT & Huang et al. & yes/yes/yes & & $\begin{array}{l}\text { parenteral } \\
\text { glutamine vs. } \\
\text { placebo }\end{array}$ & no difference \\
\hline $\mathrm{CT}+\mathrm{RT}$ & $\begin{array}{l}\text { Porteder et } \\
\text { al. }\end{array}$ & no/yes/no & $\mathrm{P}$ & PGE2 or nothing & $\begin{array}{l}\text { significant reduction } \\
\text { (less pain) }\end{array}$ \\
\hline RT & Matejka et al. & no/yes/no & $\mathrm{T}$ & $\begin{array}{l}\text { PGE2 tablets four } \\
\text { times a day }\end{array}$ & $\begin{array}{l}\text { reduction of } \\
\text { mucositis severity }\end{array}$ \\
\hline $\mathrm{CT}+\mathrm{RT}$ & $\begin{array}{l}\text { Hasenau et } \\
\text { al. }\end{array}$ & no/no/no & $\begin{array}{l}P \\
+ \\
T\end{array}$ & $\begin{array}{l}\mathrm{P}+\mathrm{T} \text { hydrogen } \\
\text { peroxide, nystatin, }\end{array}$ & $\begin{array}{l}\text { lower incidence of } \\
\text { mucositis }\end{array}$ \\
\hline RT & $\begin{array}{l}\text { Rothwell et } \\
\text { al. }\end{array}$ & yes/yes/yes & $\mathrm{P}$ & $\begin{array}{l}\text { hydrocortisone, } \\
\text { nystatin, } \\
\text { tetracyclines, } \\
\text { diphenhydramine } \\
\text { vs. placebo }\end{array}$ & $\begin{array}{l}\text { significant reduction } \\
\text { of incidence }\end{array}$ \\
\hline $\mathrm{RT}$ & $\begin{array}{l}\text { Maciejewski } \\
\text { et al. }\end{array}$ & no/yes/no & $\mathrm{p}$ & $\begin{array}{l}\text { applied to one side } \\
\text { of buccal mucosa }\end{array}$ & $\begin{array}{l}\text { significant reduction } \\
\text { compared with } \\
\text { contralateral side }\end{array}$ \\
\hline RT & Barker et al. & yes/yes/yes & & $\begin{array}{l}\text { oral hygiene+ } \\
\text { sucralfate vs. } \\
\text { diphenhydramine+ } \\
\text { kaolin-pectin }\end{array}$ & no difference \\
\hline $\mathrm{CT}+\mathrm{RT}$ & Berger et al. & no/yes/no & $\mathrm{T}$ & $\begin{array}{l}\text { capsaicin in a } \\
\text { candy vehicle }\end{array}$ & $\begin{array}{l}\text { significant temporary } \\
\text { pain relief }\end{array}$ \\
\hline $\mathrm{CT}+\mathrm{RT}$ & Mills et al. & yes/yes/no & $\mathrm{P}$ & $\begin{array}{l}\text { betacarotene or } \\
\text { nothing }\end{array}$ & $\begin{array}{l}\text { decreased severity } \\
\text { in the treatment } \\
\text { group }\end{array}$ \\
\hline RT & Bourhis et al. & yes/yes/no & $\mathrm{p}$ & $\begin{array}{l}\text { amifostine or } \\
\text { nothing }\end{array}$ & $\begin{array}{l}\text { marked reduction of } \\
\text { mucositis } \\
\text { (tolerance was poor) }\end{array}$ \\
\hline RT & $\begin{array}{l}\text { Koukourakis } \\
\text { et al. }\end{array}$ & yes/yes/yes & $\mathrm{p}$ & $\begin{array}{l}\text { amifostine vs. } \\
\text { saline }\end{array}$ & $\begin{array}{l}\text { significant reduction } \\
\text { of mucositis }\end{array}$ \\
\hline $\mathrm{RT}$ & $\begin{array}{l}\text { Schonek-as } \\
\text { et al. }\end{array}$ & no/yes/no & $\mathrm{p}$ & $\begin{array}{l}\text { amifostine vs. } \\
\text { controls }\end{array}$ & $\begin{array}{l}\text { significant reduction } \\
\text { of mucositis }\end{array}$ \\
\hline RT & Wagner et al. & yes/yes/no & $\mathrm{p}$ & $\begin{array}{l}\text { amifostine or } \\
\text { nothing }\end{array}$ & $\begin{array}{l}\text { significant reduction } \\
\text { of mucositis }\end{array}$ \\
\hline $\mathrm{CT}+\mathrm{RT}$ & Buntzel et al. & yes/yes/no & $\mathrm{p}$ & $\begin{array}{l}\text { amifostine or } \\
\text { nothing }\end{array}$ & $\begin{array}{l}\text { sig. reduction of } \\
\text { mucositis and } \\
\text { xerostomia }\end{array}$ \\
\hline $\mathrm{CT}+\mathrm{RT}$ & Peters et al. & yes/yes/no & $\mathrm{p}$ & $\begin{array}{l}\text { amifostine or } \\
\text { nothing }\end{array}$ & $\begin{array}{l}\text { no significant } \\
\text { difference }\end{array}$ \\
\hline $\mathrm{CT}+\mathrm{RT}$ & Vacha et al. & yes/yes/no & $\mathrm{p}$ & $\begin{array}{l}\text { amifostine or } \\
\text { nothing }\end{array}$ & $\begin{array}{l}\text { trend towards } \\
\text { reduction of } \\
\text { mucositis }\end{array}$ \\
\hline
\end{tabular}




\begin{tabular}{|l|l|l|l|l|l|}
\hline CT+RT & Osaki et al. & yes/yes/no & $\mathrm{p}$ & $\begin{array}{l}\text { Vitamins C+E, } \\
\text { glutathione } \pm \\
\text { azelastine }\end{array}$ & significant reduction \\
\hline RT & Pillsbury et al. & yes/yes/yes & $\mathrm{p}$ & $\begin{array}{l}\text { indomethacin vs. } \\
\text { placebo }\end{array}$ & $\begin{array}{l}\text { significant delay of } \\
\text { mucositis onset }\end{array}$ \\
\hline CT+RT & Mose et al. & no/yes/no & $\mathrm{p}$ & $\begin{array}{l}\text { i.m. } \\
\text { immunoglobulins }\end{array}$ & $\begin{array}{l}\text { significant reduction } \\
\text { in CT+RT patients, } \\
\text { no difference in RT }\end{array}$ \\
\hline RT & Wagner et al. & yes/yes/no & $\mathrm{p}$ & $\begin{array}{l}\text { RT + GM-CSF vs. } \\
\text { historical control }\end{array}$ & $\begin{array}{l}\text { significant lower } \\
\text { severity of mucositis }\end{array}$ \\
\hline RT & $\begin{array}{l}\text { Makkonen et } \\
\text { al. }\end{array}$ & no/yes/no & $\mathrm{p}$ & $\begin{array}{l}\text { sucralfate } \pm \text { GM- } \\
\text { CSF }\end{array}$ & no difference \\
\hline RT & Kannan et al. & no/yes/no & $\mathrm{p}$ & RT+GM-CSF & $\begin{array}{l}\text { lower incidence of } \\
\text { severe mucositis }\end{array}$ \\
\hline CT+RT & Rosso et al. & no/yes/no & $\mathrm{p}$ & $\begin{array}{l}\text { GM-CSF vs. } \\
\text { historical control } \\
\text { sig. lower incidence } \\
\text { of severe mucositis }\end{array}$ & $\begin{array}{l}\text { lower incidence of } \\
\text { severe mucositis }\end{array}$ \\
\hline RT & $\begin{array}{l}\text { Mascarin et } \\
\text { al. }\end{array}$ & yes/yes/no & $\mathrm{p}$ & RT \pm G-CSF & $\begin{array}{l}\text { less treatment } \\
\text { interruptions only }\end{array}$ \\
\hline RT & $\begin{array}{l}\text { Schneider et } \\
\text { al. }\end{array}$ & yes/yes/yes & $\mathrm{p}$ & RT $\pm G-C S F$ & $\begin{array}{l}\text { sig. reduced } \\
\text { incidence of severe } \\
\text { mucositis }\end{array}$ \\
\hline CT+RT & Bubley et al. & yes/yes/yes & $\mathrm{p}$ & $\begin{array}{l}\text { acyclovir vs. } \\
\text { placebo }\end{array}$ & $\begin{array}{l}\text { no impact upon } \\
\text { incidence and } \\
\text { severity } \\
\text { of mucositis }\end{array}$ \\
\hline
\end{tabular}

Table.2.12.1.1: RIOM the clinical trials that have been done until 2001 [4]

$\mathrm{RT}=$ Radiotherapy, $\mathrm{P} / \mathrm{T}=$ Prevention or Treatment, $\mathrm{CT}=$ Chemotherapy, $\mathrm{HD}-\mathrm{CT}=$ High-dose Chemotherapy, BMT = Bone Marrow Transplantation, $\mathrm{TBI}=$ Total Body Irradiation, im= intramuscular.

A recent search on clinical trials website of the National Institute of Health $(\mathrm{NIH})$ for RIOM is briefed in Table.2.12.1.2. We have documented 40 RIOM treatment and prevention clinical trials. 


\begin{tabular}{|c|c|c|c|}
\hline $\begin{array}{l}\text { NCT } \\
\text { Num } \\
\text { ber }\end{array}$ & Title & Conditions & $\begin{array}{l}\text { Last } \\
\text { Updated }\end{array}$ \\
\hline $\begin{array}{l}\text { NCT } \\
0250 \\
8389\end{array}$ & $\begin{array}{l}\text { A Study of GC4419 Protection } \\
\text { Against Radiation Induced Oral } \\
\text { Mucositis in Patients With Head \& } \\
\text { Neck Cancer }\end{array}$ & $\begin{array}{l}\text { Radiation Induced Oral } \\
\text { Mucositis }\end{array}$ & 23-Nov-15 \\
\hline $\begin{array}{l}\text { NCT } \\
0069 \\
8204\end{array}$ & $\begin{array}{l}\text { Cox-2 Inhibition in Radiation- } \\
\text { induced Oral Mucositis }\end{array}$ & Oral Mucositis & 7-May-14 \\
\hline $\begin{array}{l}\text { NCT } \\
0081 \\
4359\end{array}$ & $\begin{array}{l}\text { Magic Mouthwash Plus Sucralfate } \\
\text { Versus Benzydamine Hydrochloride } \\
\text { for the Treatment of Radiation- } \\
\text { induced Mucositis }\end{array}$ & $\begin{array}{l}\text { Head and Neck } \\
\text { Cancer|Mucositis }\end{array}$ & 19-Jan-11 \\
\hline $\begin{array}{l}\text { NCT } \\
0140 \\
0620\end{array}$ & $\begin{array}{l}\text { Safety and Efficacy of IZN-6N4 Oral } \\
\text { Rinse for the Prevention of Oral } \\
\text { Mucositis in Patients With Head and } \\
\text { Neck Cancer }\end{array}$ & Oral Mucositis & 9-Nov-15 \\
\hline $\begin{array}{l}\text { NCT } \\
0005 \\
1441\end{array}$ & $\begin{array}{l}\text { Safety \& Efficacy Study of } \\
\text { Benzydamine Oral Rinse for the } \\
\text { Treatment of Oral Mucositis (Mouth } \\
\text { Sores) Resulting From Radiation } \\
\text { Therapy for Cancer of the Oral } \\
\text { Cavity, Oropharynx, or Nasopharynx }\end{array}$ & Stomatitis|Radiation Effects & 17-May-11 \\
\hline $\begin{array}{l}\text { NCT } \\
0260 \\
8879\end{array}$ & $\begin{array}{l}\text { Oral Care Protocol for the } \\
\text { Management of Chemotherapy and } \\
\text { Radiation Therapy-Induced Oral } \\
\text { Mucositis }\end{array}$ & Oral Mucositis|Oral Cancer & 17-Nov-15 \\
\hline $\begin{array}{l}\text { NCT } \\
0146 \\
5308\end{array}$ & $\begin{array}{l}\text { The Effect of Honey on Xerostomia } \\
\text { and Oral Mucositis }\end{array}$ & Head and Neck Cancer & 7-Oct-14 \\
\hline $\begin{array}{l}\text { NCT } \\
0137 \\
5088\end{array}$ & $\begin{array}{l}\text { Assessing the Preventing and } \\
\text { Therapeutic Effect of Propolis in } \\
\text { Radiotherapy Induced Mucositis of } \\
\text { Head and Neck Cancers }\end{array}$ & $\begin{array}{l}\text { Radiation-induced } \\
\text { Mucositis of Oral Mucous } \\
\text { Membranes }\end{array}$ & 21-Nov-12 \\
\hline $\begin{array}{l}\text { NCT } \\
0106 \\
6741\end{array}$ & $\begin{array}{l}\text { Prevention of Radiation-induced } \\
\text { Severe Oral Mucositis in Oral } \\
\text { Cavity, Oropharynx, Hypopharynx, } \\
\text { and Cavum Cancer }\end{array}$ & $\begin{array}{l}\text { Oropharynx } \\
\text { Cancer|Hypopharynx } \\
\text { Cancer }\end{array}$ & $31-$ Oct-12 \\
\hline $\begin{array}{l}\text { NCT } \\
0000 \\
6994\end{array}$ & $\begin{array}{l}\text { S9908: Glutamine in Treating } \\
\text { Mucositis Caused by Radiation } \\
\text { Therapy in Patients With Newly } \\
\text { Diagnosed Cancer of the Mouth or } \\
\text { Throat }\end{array}$ & $\begin{array}{l}\text { Cancer-related } \\
\text { Problem/Condition|Head } \\
\text { and Neck Cancer|Pain }\end{array}$ & 17-Nov-15 \\
\hline
\end{tabular}




\begin{tabular}{|c|c|c|c|}
\hline $\begin{array}{l}\text { NCT } \\
0243 \\
0298\end{array}$ & $\begin{array}{l}\text { Topical/Oral Melatonin for } \\
\text { Preventing Concurrent } \\
\text { Radiochemotherapy Induced Oral } \\
\text { Mucositis/Xerostomia Cancer } \\
\text { Patients }\end{array}$ & Head and Neck Cancer & 12-May-15 \\
\hline $\begin{array}{l}\text { NCT } \\
0239 \\
7486\end{array}$ & $\begin{array}{l}\text { The Impact of Pentoxifylline and } \\
\text { Vitamin E on Radiotherapy-induced } \\
\text { Toxicity in Head \& Neck Cancer } \\
\text { Patients }\end{array}$ & Head and Neck Neoplasms & 27-May-15 \\
\hline $\begin{array}{l}\text { NCT } \\
0194 \\
1992\end{array}$ & $\begin{array}{l}\text { Role of SAMITALI®® in the Relief of } \\
\text { Chemo-radiation (CT-RT) Induced } \\
\text { Oral Mucositis in Head and Neck } \\
\text { Cancer Patients }\end{array}$ & $\begin{array}{l}\text { Head-and-neck Squamous } \\
\text { Cell Carcinoma|Oral } \\
\text { Mucositis. }\end{array}$ & 24-Mar-15 \\
\hline $\begin{array}{l}\text { NCT } \\
0131 \\
8889\end{array}$ & $\begin{array}{l}\text { Dexpanthenol Mouthwash to Treat } \\
\text { Oral Mucositis }\end{array}$ & $\begin{array}{l}\text { Oral Mucositis (Ulcerative) } \\
\text { Due to Radiation }\end{array}$ & 5-Jul-11 \\
\hline $\begin{array}{l}\text { NCT } \\
0201 \\
6807\end{array}$ & $\begin{array}{l}\text { ZeroTolerance Mucositis: Managing } \\
\text { Oral and Alimentary Mucositis With } \\
\text { High Potency Sucralfate - ProThelial }\end{array}$ & $\begin{array}{l}\text { Oral } \\
\text { Mucositis|Nausea|Vomiting| } \\
\text { Diarrhea }\end{array}$ & 16-Dec-13 \\
\hline $\begin{array}{l}\text { NCT } \\
0029 \\
3462\end{array}$ & $\begin{array}{l}\text { GM-CSF Mouthwash for Preventing } \\
\text { and Treating Mucositis in Patients } \\
\text { Who Are Undergoing Radiation } \\
\text { Therapy for Head and Neck Cancer }\end{array}$ & $\begin{array}{l}\text { Head and Neck } \\
\text { Cancer|Mucositis|Radiation } \\
\text { Toxicity }\end{array}$ & 14-May-13 \\
\hline $\begin{array}{l}\text { NCT } \\
0072 \\
8585\end{array}$ & $\begin{array}{l}\text { Palifermin in Preventing Oral } \\
\text { Mucositis Caused by Chemotherapy } \\
\text { and/or Radiation Therapy in Young } \\
\text { Patients Undergoing Stem Cell } \\
\text { Transplant }\end{array}$ & $\begin{array}{l}\text { Breast Cancer|Graft Versus } \\
\text { Host Disease|Kidney } \\
\text { Cancer|Leukemia|Lympho } \\
\text { ma|Mucositis|Multiple } \\
\text { Myeloma|Plasma Cell } \\
\text { Neoplasm|Myelodysplastic } \\
\text { Syndromes|Neuroblastoma } \\
\text { |Ovarian } \\
\text { Cancer|Sarcoma|Testicular } \\
\text { Germ Cell Tumor }\end{array}$ & 30-May-13 \\
\hline $\begin{array}{l}\text { NCT } \\
0260 \\
4329\end{array}$ & $\begin{array}{l}\text { Feasibility Study of a Protocol to } \\
\text { Treat Pediatric Oral Mucositis by } \\
\text { Low-level Laser Therapy }\end{array}$ & Oral Mucositis & 12-Nov-15 \\
\hline $\begin{array}{l}\text { NCT } \\
0207 \\
5749\end{array}$ & $\begin{array}{l}\text { Comparing Triamcinolone Acetonide } \\
\text { Mucoadhesive Films With Licorice } \\
\text { Mucoadhesive Films }\end{array}$ & Mucositis & 9-Jul-14 \\
\hline $\begin{array}{l}\text { NCT } \\
0138 \\
5748\end{array}$ & $\begin{array}{l}\text { Efficacy and Safety Study of } \\
\text { Clonidine Lauriad }{ }^{\circledR} \text { to Treat Oral } \\
\text { Mucositis }\end{array}$ & Oral Mucositis & 7-Jul-15 \\
\hline $\begin{array}{l}\text { NCT } \\
0170 \\
7641\end{array}$ & $\begin{array}{l}\text { Effect of Lactobacillus Brevis CD2 in } \\
\text { Prevention of Radio-chemotherapy } \\
\text { Induced Oral Mucositis in Head and } \\
\text { Neck Cancer }\end{array}$ & Mucositis & 19-May-14 \\
\hline
\end{tabular}




\begin{tabular}{|c|c|c|c|}
\hline $\begin{array}{l}\text { NCT } \\
0061 \\
3743\end{array}$ & $\begin{array}{l}\text { Effect of Topical Morphine } \\
\text { (Mouthwash) on Oral Pain Due to } \\
\text { Chemo- and/or Radiotherapy } \\
\text { Induced Mucositis }\end{array}$ & Cancer|Mucositis & 12-Jan-10 \\
\hline $\begin{array}{l}\text { NCT } \\
0043 \\
1925\end{array}$ & $\begin{array}{l}\text { Can Cytokines Predict the Severity } \\
\text { of Acute Mucositis and the Need for } \\
\text { Gastrostomy Tubes (PEG)? }\end{array}$ & $\begin{array}{l}\text { Oral Mucositis|Xerostomia| } \\
\text { Weight Loss|Head and } \\
\text { Neck Cancer }\end{array}$ & 9-Aug-07 \\
\hline $\begin{array}{l}\text { NCT } \\
0180 \\
6272\end{array}$ & $\begin{array}{l}\text { Recombinant Human Granulocyte } \\
\text { Macrophage Colony Stimulating } \\
\text { Factor(rhGM-CSF) Treating Oral } \\
\text { Mucositis }\end{array}$ & Nasopharyngeal Cancers & 27-Mar-13 \\
\hline $\begin{array}{l}\text { NCT } \\
0187 \\
6407\end{array}$ & $\begin{array}{l}\text { Effectiveness of Low Energy Laser } \\
\text { Treatment in Oral Mucositis Induced } \\
\text { by Chemotherapy and Radiotherapy } \\
\text { in Head and Neck Cancer }\end{array}$ & Oral Mucositis & 30-Apr-15 \\
\hline $\begin{array}{l}\text { NCT } \\
0058 \\
4597\end{array}$ & $\begin{array}{l}\text { A Trial of Homeopathic Medication } \\
\text { TRAUMEEL S for the Treatment of } \\
\text { Radiation-Induced Mucositis }\end{array}$ & $\begin{array}{l}\text { Mucositis|Head and Neck } \\
\text { Cancer }\end{array}$ & 10-Dec-10 \\
\hline $\begin{array}{l}\text { NCT } \\
0061 \\
5420\end{array}$ & $\begin{array}{l}\text { A Randomized Placebo-Controlled } \\
\text { Trial of Manuka Honey for Oral } \\
\text { Mucositis Due to Radiation Therapy } \\
\text { for Cancer }\end{array}$ & $\begin{array}{l}\text { Radiotherapy Induced } \\
\text { Mucositis|Head and Neck } \\
\text { Cancer }\end{array}$ & 22-May-12 \\
\hline $\begin{array}{l}\text { NCT } \\
0189 \\
8091\end{array}$ & $\begin{array}{l}\text { Herbal Mouthrinse for Oral Mucositis } \\
\text { Study }\end{array}$ & Oral Mucositis & 21-Sep-15 \\
\hline $\begin{array}{l}\text { NCT } \\
0177 \\
2706\end{array}$ & $\begin{array}{l}\text { Laser Mucite ORL : Effectiveness of } \\
\text { Laser Therapy for Mucositis Induced } \\
\text { by a Radio-chemotherapy in Head } \\
\text { and Neck Cancer }\end{array}$ & $\begin{array}{l}\text { Oral Squamous Cell } \\
\text { Carcinoma|Squamous Cell } \\
\text { Carcinoma of } \\
\text { Oropharynx|Squamous Cell } \\
\text { Carcinoma of } \\
\text { Hypopharynx|Oral } \\
\text { Mucositis }\end{array}$ & 17-Jan-13 \\
\hline $\begin{array}{l}\text { NCT } \\
0183 \\
7446\end{array}$ & $\begin{array}{l}\text { Morphine Mouthwash for } \\
\text { Management of Oral Mucositis in } \\
\text { Patients With Head and Neck } \\
\text { Cancer }\end{array}$ & Stomatitis & 22-Apr-13 \\
\hline $\begin{array}{l}\text { NCT } \\
0230 \\
9437\end{array}$ & $\begin{array}{l}\text { Early Use of Opioid to Control Local } \\
\text { Mucosa Pain Induced by Irradiation } \\
\text { in Nasopharyngeal Carcinoma } \\
\text { Patients }\end{array}$ & $\begin{array}{l}\text { Nutrition Disorders|Quality } \\
\text { of Life }\end{array}$ & 3-Dec-14 \\
\hline $\begin{array}{l}\text { NCT } \\
0166 \\
8849\end{array}$ & $\begin{array}{l}\text { Edible Plant Exosome Ability to } \\
\text { Prevent Oral Mucositis Associated } \\
\text { With Chemoradiation Treatment of } \\
\text { Head and Neck Cancer }\end{array}$ & $\begin{array}{l}\text { Head and Neck } \\
\text { Cancer|Oral Mucositis }\end{array}$ & 12-May-15 \\
\hline
\end{tabular}




\begin{tabular}{|c|c|c|c|}
\hline $\begin{array}{l}\text { NCT } \\
0197 \\
5688\end{array}$ & $\begin{array}{l}\text { A Pharmacokinetic Study of Single } \\
\text { Doses of Sativex in Treatment- } \\
\text { induced Mucositis }\end{array}$ & $\begin{array}{l}\text { Head and Neck Squamous } \\
\text { Cell Carcinoma }\end{array}$ & 12-May-15 \\
\hline $\begin{array}{l}\text { NCT } \\
0125 \\
2498\end{array}$ & $\begin{array}{l}\text { Evaluation of the Role of } \\
\text { Prostaglandins in Radiation-induced } \\
\text { Mucositis }\end{array}$ & $\begin{array}{l}\text { Cancer of the Head and } \\
\text { Neck|Radiotherapy }\end{array}$ & 3-Feb-14 \\
\hline $\begin{array}{l}\text { NCT } \\
0184 \\
0436\end{array}$ & $\begin{array}{l}\text { Efficacy of MUCIPLIQ on the } \\
\text { Incidence of Radio-chemotherapy- } \\
\text { induced Mucositis in Patients } \\
\text { Suffering From Oral Cancer }\end{array}$ & $\begin{array}{l}\text { Oral Mucositis|Carcinoma } \\
\text { in Situ of Upper Respiratory } \\
\text { Tract }\end{array}$ & 15-May-14 \\
\hline $\begin{array}{l}\text { NCT } \\
0069 \\
9569\end{array}$ & $\begin{array}{l}\text { Hyperimmune Colostrum and Oral } \\
\text { Mucositis }\end{array}$ & Head and Neck Cancer & 22-Jul-08 \\
\hline $\begin{array}{l}\text { NCT } \\
0255 \\
5501\end{array}$ & $\begin{array}{l}\text { Oral Mucositis and Laser Therapy } \\
\text { Associated With Photodynamic } \\
\text { Therapy }\end{array}$ & Oral Mucositis & 18-Sep-15 \\
\hline $\begin{array}{l}\text { NCT } \\
0205 \\
0503\end{array}$ & $\begin{array}{l}\text { Intranasal Transmucosal Fentanyl } \\
\text { Pectin for Breakthrough Cancer } \\
\text { Pain in Radiation-induced } \\
\text { Oropharyngeal Mucositis }\end{array}$ & $\begin{array}{l}\text { Breakthrough } \\
\text { Pain|Mucositis| } \\
\text { Radiotherapy| } \\
\text { Chemotherapy|Head and } \\
\text { Neck Cancer }\end{array}$ & 16-Mar-15 \\
\hline $\begin{array}{l}\text { NCT } \\
0188 \\
3908\end{array}$ & $\begin{array}{l}\text { Acupuncture in Reducing the } \\
\text { Severity of Chemoradiation-induced } \\
\text { Mucositis in Patients With } \\
\text { Oropharyngeal Cancer }\end{array}$ & $\begin{array}{l}\text { Mucositis|Oropharyngeal } \\
\text { Cancer }\end{array}$ & 3-Sep-15 \\
\hline $\begin{array}{l}\text { NCT } \\
0143 \\
2873\end{array}$ & $\begin{array}{l}\text { Oral Selenium Therapy for the } \\
\text { Prevention of Mucositis }\end{array}$ & $\begin{array}{l}\text { Mucositis|Hematopoietic } \\
\text { Stem Cell Transplantation }\end{array}$ & 31-May-12 \\
\hline
\end{tabular}

Table.2.12.1.2: Clinical trials for RIOM as listed on www. ClinicalTrials.gov when searched in

Nov 2015

\subsection{CONCLUSION}

Radiation-induced oral mucositis is mostly a self-limited radiotherapy-induced normal tissue injury side effect in Head and Neck cancer patients. However, in moderately to severely sick patients, it could be a lethal injury. Many preclinical and clinical studies have been conducted for the prevention and treatment of RIOM and there are currently numerous prevention and treatment strategies and agents. 
However, there is no single agent or management regimen that has been agreed upon between caregivers that significantly improves such injury to a clinically relevant level. Still, good oral hygiene and patient education are important strategies to minimize the injury. Mesenchymal stromal cells therapy for radiation-induced oral mucositis showed promising therapeutic and clinically relevant responses. However, more studies are still needed to confirm such therapeutic gain. 
This page is intentionally left blank 
The next chapter will be a complete review on mesenchymal stromal/stem cells applications in radiation oncology regenerative medicine including radiation-induced oral mucositis. 


\section{Chapter 3 REVIEW ON MESENCHYMAL STROMAL CELLS THERAPY IN RADIATION ONCOLOGY REGENERATIVE MEDICINE}

Osama Muhammad Maria, MD, MSc ${ }^{1,3,4}$, Nicoletta Eliopoulos, $\mathrm{PhD}^{2,4}$ and Thierry Muanza, MD, MSc ${ }^{1,3,4,5}$

1 Experimental Medicine Department, Faculty of Medicine, McGill University, Montreal, Quebec, Canada

2 Surgery Department, Faculty of Medicine, McGill University, Montreal, Quebec, Canada

3 Radiation Oncology Department, Jewish General Hospital, McGill University, Montreal, Quebec, Canada

4 Lady Davis Institute for Medical Research, Jewish General Hospital, McGill University, Montreal, Quebec, Canada

5 Oncology Department, McGill University, Montreal, Quebec, Canada

\section{AUTHOR CONTRIBUTIONS}

Osama Maria: Conception and design, collection and/or assembly of data, review writing, final approval of the review.

Nicoletta Eliopoulos: Conception, design and final approval of the review.

Thierry Muanza: Conception and design, financial support and final approval of the review. 


\section{THE CORRESPONDING AUTHOR}

Dr. Thierry Muanza, MD MSc FRCPC

Radiation Oncology Translational Research Lab, Department of Radiation Oncology, Jewish General Hospital and Lady Davis Institute Research Centre, McGill University

3755 Côte-St.-Catherine Road, Suite G002, Montréal, Québec, Canada, H3T 1E2

Tel: +1 (514)-340-8288, Fax: + 1 (514)-340-7548, Email: tmuanza@yaoo.com

Disclaimer: None 


\section{KEY WORDS:}

Adipose Tissue, Anti-inflammatory, Cell Cycle, DNA Repair, Mesenchymal Stromal Cells, MSC, Normal Tissue Injury, Radiation Oncology Regenerative Medicine, Radiation Resistance 


\section{ABBREVIATIONS}

aMSCs Adipose tissue-derived mesenchymal stromal cells

ATM Ataxia telangiectasia mutated protein

b-FGF Basic fibroblast growth factor

Chk Check point cell cycle kinase

DSB Double stranded DNA breaks

HGF Hepatocyte growth factor

HR Homologous recombination

HSCs Hematopoietic stem cells

IL-10 Interleukine-10

IL-1 $\beta \quad$ Interleukine-1-beta

IDO Indoleamine 2,3-dioxygenase

INF-Y Interferon-gamma

MSCs Mesenchymal stromal cells

NHEJ Non-homologous end-joining

NK Natural killer cells

NO Nitric oxide

PGE2 Prostaglandin-E2 
RORM Radiation oncology regenerative medicine

TGF- $\boldsymbol{\beta} \quad$ Tumor growth factor-beta

TNF- $\alpha \quad$ Tumor necrosis factor-alpha 


\subsection{ABSTRACT}

Mesenchymal stromal cells (MSCs) are multipotent somatic cells resident in many tissues and organs. They have specific characteristics that distinguish them from other cell types. They are self-renewing cells with multi-lineage differentiation potential. In addition, they possess anti-inflammatory and immunomodulatory properties. Studies have shown that they could be used as vehicles to deliver certain therapeutic gene products as well. These cells possess secretory capabilities of certain cytokines and growth factors that mediate various paracrine effects. They increase the secretion of the anti-inflammatory interleukin-10 (IL-10) together with lowering the availabilities of tumor necrosis factor-alpha (TNF- $\alpha$ ), interferon-gamma (INF-y), and interleukin -1-beta (IL-1 $\beta$ ) by signaling to the immune system elements, e.g. dendritic cells, T-cells, B-cells, and natural Killer cells (NK cells). Recently, studies have investigated such anti-inflammatory properties of MSCs in the repair of radiation-induced normal tissue injury, also called radiation oncology regenerative medicine (RORM), supported by the recently known MSCs radiation resistance potential. In this review, we will summarize MSCs radio-resistant mechanisms, antiinflammatory properties, and their application in RORM with special attention on adipose tissue-derived MSCs (aMSCs).

\subsection{INTRODUCTION}

Mesenchymal stromal/Stem cells (MSCs) are multipotent somatic progenitor cells that have been isolated from different tissues, such as bone marrow, adipose tissue, muscles and skin $[74,75,142]$. They can be expanded ex-vivo to hundreds of million 
cells, maintaining their phenotype and characteristics, and used as therapies in different diseases $[74,75,142]$. Another property of these cells is their homing to the site of tissue injury, an ability that widens the choices for their route of administration $[74,78,143]$. In addition to their multi-lineage differentiation potential [113], these cells possess anti-inflammatory and immunomodulatory properties and paracrine effects that qualified them for regenerative medicine applications (Figure.3.2.1) [56, 144-147]. Furthermore, MSCs could be genetically engineered and used as vehicles for delivering therapeutic gene products [148-150]. Studies in radiotherapy have shown that MSCs can be recruited to the radiation injury site where they secrete many cytokines and growth factors, e.g. prostaglandin-E2 (PGE2), nitric oxide (NO), hepatocyte growth factor (HGF), interleukin-10 (IL-10), tumor growth factor-beta (TGF- $\beta$ ), and indoleamine 2,3-dioxygenase (IDO) [151]. These soluble mediators inhibit the major components of the immune system and inflammation, e.g. dendritic cells, T-cells, B-cells, and natural killer cells (NK cells) [151]. The final result will be an increase in the secretion of the anti-inflammatory interleukin-10 (IL-10) together with lowering the availability of pro-inflammatory mediators and cytokines, e.g. tumor necrosis factor-alpha (TNF- $\alpha$ ), interferon-gamma (INF- $\gamma$ ), and interleukin -1-beta (IL1ß) [151] (Figure.3.2.1). 


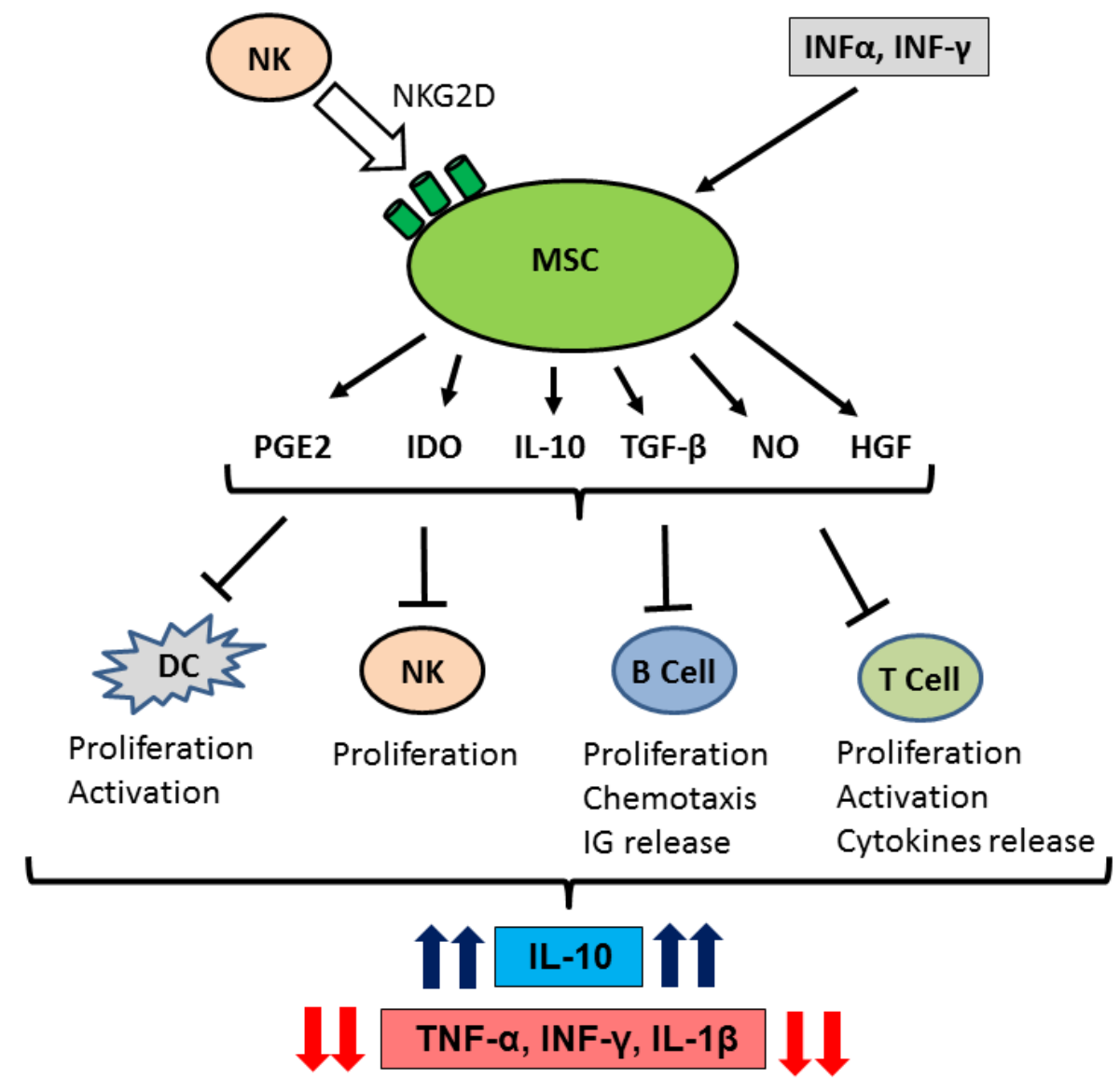

Figure.3.2.1: MSCs anti-inflammatory properties

MSCs recruited to the radiation injury site secrete many cytokines and growth factors, e.g. prostaglandin-E2 (PGE2), nitric oxide (NO), hepatocyte growth factor (HGF), interleukin-10 (IL-10), tumor growth factor-beta (TGF- $\beta$ ), and indoleamine 2,3-dioxygenase (IDO). These soluble mediators inhibit the major components of the immune system and inflammation, e.g. dendritic cells, T-cells, B-cells, and natural killer cells (NK cells). The final result will be an increase in the secretion of the anti-inflammatory interleukin-10 (IL-10) together with lowering the availability of the pro-inflammatory mediators and cytokines, e.g. tumor necrosis factor-alpha (TNF- $\alpha$ ), interferon-gamma (INF- $\boldsymbol{\gamma}$ ), and interleukin -1-beta (IL-1 $\beta$ ) [15]. 


\subsection{MESENCHYMAL STROMAL CELLS (MSCs) CLINICAL TRIALS}

\section{IN VARIOUS DISORDERS}

MSCs have been applied for the repair of arthritis[63], cardiac muscle [152, 153], lung tissue [150], diabetes [154], skin [81, 83, 155, 156], skeletal tissue [157], and digestive tract tissue $[87,148,158]$. Table.3.3.1 shows 92 recent clinical trials for MSCs therapies in various disorders.

\begin{tabular}{|c|c|c|c|c|}
\hline $\begin{array}{l}\text { NCT } \\
\#\end{array}$ & Title & Conditions & Interventions & $\begin{array}{l}\text { Last } \\
\text { Verified }\end{array}$ \\
\hline $\begin{array}{l}\text { NCT } \\
0158 \\
9549\end{array}$ & $\begin{array}{l}\text { Mesenchymal Stromal } \\
\text { Cells for Acute Graft } \\
\text { Versus Host Disease }\end{array}$ & $\begin{array}{l}\text { Acute GVH } \\
\text { Disease }\end{array}$ & $\begin{array}{l}\text { Biological: } \\
\text { Mesenchymal stromal } \\
\text { cell therapy }\end{array}$ & Jun-15 \\
\hline $\begin{array}{l}\text { NCT } \\
0205 \\
7965\end{array}$ & $\begin{array}{l}\text { Mesenchymal Stromal } \\
\text { Cell Therapy in Renal } \\
\text { Recipients }\end{array}$ & $\begin{array}{l}\text { Renal Transplant } \\
\text { Rejection|Fibrosis }\end{array}$ & $\begin{array}{l}\text { Drug: Mesenchymal } \\
\text { Stromal Cells }\end{array}$ & Mar-15 \\
\hline $\begin{array}{l}\text { NCT } \\
0203 \\
2446\end{array}$ & $\begin{array}{l}\text { Umbilical Cord Derived } \\
\text { Mesenchymal Stromal } \\
\text { Cells For The } \\
\text { Treatment of Severe } \\
\text { Steroid-resistant Graft } \\
\text { Versus Host Disease }\end{array}$ & $\begin{array}{l}\text { Hematologic } \\
\text { Malignancies }\end{array}$ & $\begin{array}{l}\text { Biological: } \\
\text { UMBILICAL CORD } \\
\text { DERIVED } \\
\text { MESENCHYMAL } \\
\text { STROMAL CELLS } \\
\text { (UC-MSC) }\end{array}$ & Apr-15 \\
\hline $\begin{array}{l}\text { NCT } \\
0201 \\
2153\end{array}$ & $\begin{array}{l}\text { Mesenchymal Stromal } \\
\text { Cells in Kidney } \\
\text { Transplant Recipients }\end{array}$ & $\begin{array}{l}\text { Kidney Transplant } \\
\text { Rejection }\end{array}$ & $\begin{array}{l}\text { Biological: } \\
\text { Mesenchymal Stromal } \\
\text { Cells }\end{array}$ & Oct-15 \\
\hline $\begin{array}{l}\text { NCT } \\
0109 \\
0817\end{array}$ & $\begin{array}{l}\text { An Australian Study of } \\
\text { Mesenchymal Stromal } \\
\text { Cells for Crohn's } \\
\text { Disease }\end{array}$ & Crohn Disease & $\begin{array}{l}\text { Drug: Mesenchymal } \\
\text { stromal cells (MSC) } \\
\text { for infusion }\end{array}$ & Jun-15 \\
\hline $\begin{array}{l}\text { NCT } \\
0064 \\
4410\end{array}$ & $\begin{array}{l}\text { Autologous } \\
\text { Mesenchymal Stromal } \\
\text { Cell Therapy in Heart } \\
\text { Failure }\end{array}$ & $\begin{array}{l}\text { Congestive Heart } \\
\text { Failure }\end{array}$ & $\begin{array}{l}\text { Biological: } \\
\text { Mesenchymal stromal } \\
\text { cell| Biological: Saline }\end{array}$ & Mar-15 \\
\hline $\begin{array}{l}\text { NCT } \\
0106 \\
1099\end{array}$ & $\begin{array}{l}\text { Repeated Infusions of } \\
\text { Mesenchymal Stromal } \\
\text { Cells in Children With } \\
\text { Osteogenesis } \\
\text { Imperfecta }\end{array}$ & $\begin{array}{l}\text { Osteogenesis } \\
\text { Imperfecta Type II| } \\
\text { Osteogenesis } \\
\text { Imperfecta Type III }\end{array}$ & $\begin{array}{l}\text { Biological: } \\
\text { Mesenchymal Stromal } \\
\text { Cells }\end{array}$ & Apr-15 \\
\hline
\end{tabular}




\begin{tabular}{|c|c|c|c|c|}
\hline $\begin{array}{l}\text { NCT } \\
0215 \\
0551\end{array}$ & $\begin{array}{l}\text { Safety and Tolerability } \\
\text { Of Allogeneic } \\
\text { Mesenchymal Stromal } \\
\text { Cells in Pediatric } \\
\text { Inflammatory Bowel } \\
\text { Disease }\end{array}$ & $\begin{array}{l}\text { Inflammatory } \\
\text { Bowel Diseases }\end{array}$ & $\begin{array}{l}\text { Biological: Allogeneic } \\
\text { bone marrow-derived } \\
\text { mesenchymal stromal } \\
\text { cells }\end{array}$ & Sep-15 \\
\hline $\begin{array}{l}\text { NCT } \\
0152 \\
2716\end{array}$ & $\begin{array}{l}\text { Mesenchymal Stromal } \\
\text { Cells as Treatment of } \\
\text { Chronic Graft-versus- } \\
\text { host Disease }\end{array}$ & $\begin{array}{l}\text { Graft-Versus-Host } \\
\text { Disease }\end{array}$ & $\begin{array}{l}\text { Biological: } \\
\text { Mesenchymal stromal } \\
\text { cells }\end{array}$ & Nov-15 \\
\hline $\begin{array}{l}\text { NCT } \\
0232 \\
3789\end{array}$ & $\begin{array}{l}\text { A Phase I/II Study } \\
\text { Evaluating Allogeneic } \\
\text { Mesenchymal Stromal } \\
\text { Cells in Adults With } \\
\text { Recessive Dystrophic } \\
\text { Epidermolysis Bullosa }\end{array}$ & $\begin{array}{l}\text { Recessive } \\
\text { Dystrophic } \\
\text { Epidermolysis } \\
\text { Bullosa }\end{array}$ & $\begin{array}{l}\text { Drug: Mesenchymal } \\
\text { stromal cells }\end{array}$ & Dec-14 \\
\hline $\begin{array}{l}\text { NCT } \\
0229 \\
1770\end{array}$ & $\begin{array}{l}\text { Treatment of Chronic } \\
\text { Graft-Versus-Host } \\
\text { Disease With } \\
\text { Mesenchymal Stromal } \\
\text { Cells }\end{array}$ & $\begin{array}{l}\text { Chronic Graft- } \\
\text { Versus-Host } \\
\text { Disease }\end{array}$ & $\begin{array}{l}\text { Biological: } \\
\text { Mesenchymal Stromal } \\
\text { Cells }\end{array}$ & Nov-14 \\
\hline $\begin{array}{l}\text { NCT } \\
0176 \\
4100\end{array}$ & $\begin{array}{l}\text { Mesenchymal Stromal } \\
\text { Cells (MSCs) for the } \\
\text { Treatment of Graft } \\
\text { Versus Host Disease } \\
\text { (GVHD) }\end{array}$ & $\begin{array}{l}\text { Graft vs Host } \\
\text { Disease }\end{array}$ & $\begin{array}{l}\text { Genetic: } \\
\text { Mesenchymal stromal } \\
\text { cells }\end{array}$ & Jan-13 \\
\hline $\begin{array}{l}\text { NCT } \\
0223 \\
0514\end{array}$ & $\begin{array}{l}\text { Mesenchymal Stromal } \\
\text { Cells for the Treatment } \\
\text { of Non-union Fractures } \\
\text { of Long Bones }\end{array}$ & $\begin{array}{l}\text { Atrophic Nonunion } \\
\text { of Fracture }\end{array}$ & $\begin{array}{l}\text { Drug: XCEL-MT- } \\
\text { OSTEO- } \\
\text { ALPHA|Other: } \\
\text { autologous iliac crest| } \\
\text { Procedure: Surgery }\end{array}$ & Jul-15 \\
\hline $\begin{array}{l}\text { NCT } \\
0221 \\
5811\end{array}$ & $\begin{array}{l}\text { Treatment of Severe } \\
\text { Acute Respiratory } \\
\text { Distress Syndrome } \\
\text { With Allogeneic Bone } \\
\text { Marrow-derived } \\
\text { Mesenchymal Stromal } \\
\text { Cells }\end{array}$ & $\begin{array}{l}\text { Acute Respiratory } \\
\text { Distress Syndrome, } \\
\text { Adult }\end{array}$ & $\begin{array}{l}\text { Biological: } \\
\text { Mesenchymal stromal } \\
\text { cells }\end{array}$ & Aug-14 \\
\hline $\begin{array}{l}\text { NCT } \\
0144 \\
9032\end{array}$ & $\begin{array}{l}\text { Mesenchymal } \\
\text { STROMAL CELL } \\
\text { Therapy in Patients } \\
\text { With Chronic } \\
\text { Myocardial Ischemia } \\
\text { (My Stromal Cell Trial) }\end{array}$ & $\begin{array}{l}\text { Chronic Ischemic } \\
\text { Heart Disease }\end{array}$ & $\begin{array}{l}\text { Biological: MSC| } \\
\text { Biological: Saline }\end{array}$ & Jun-14 \\
\hline
\end{tabular}




\begin{tabular}{|c|c|c|c|c|}
\hline $\begin{array}{l}\text { NCT } \\
0258 \\
0695\end{array}$ & $\begin{array}{l}\text { A Study to Assess } \\
\text { Safety and Efficacy of } \\
\text { Umbilical Cord-derived } \\
\text { Mesenchymal Stromal } \\
\text { Cells in Knee } \\
\text { Osteoarthritis }\end{array}$ & Osteoarthritis & $\begin{array}{l}\text { Biological: umbilical- } \\
\text { cord mesenchymal } \\
\text { stromal cells| Drug: } \\
\text { Hyaluronic Acid }\end{array}$ & Oct-15 \\
\hline $\begin{array}{l}\text { NCT } \\
0103 \\
8596\end{array}$ & $\begin{array}{l}\text { Mesenchymal Stromal } \\
\text { Cells and Osteoarthritis }\end{array}$ & Osteoarthritis & & Dec-09 \\
\hline $\begin{array}{l}\text { NCT } \\
0249 \\
5766\end{array}$ & $\begin{array}{l}\text { Autologous } \\
\text { Mesenchymal Stromal } \\
\text { Cells for Multiple } \\
\text { Sclerosis }\end{array}$ & $\begin{array}{l}\text { Relapsing- } \\
\text { Remitting Multiple } \\
\text { Sclerosis| } \\
\text { Secondary } \\
\text { Progressive } \\
\text { Multiple Sclerosis }\end{array}$ & $\begin{array}{l}\text { Drug: XCEL-MC- } \\
\text { ALPHA|Drug: Placebo }\end{array}$ & Nov-15 \\
\hline $\begin{array}{l}\text { NCT } \\
0256 \\
5459\end{array}$ & $\begin{array}{l}\text { MSC and Kidney } \\
\text { Transplant Tolerance } \\
\text { (Phase A) }\end{array}$ & $\begin{array}{l}\text { Chronic Renal } \\
\text { Failure }\end{array}$ & $\begin{array}{l}\text { Biological: } \\
\text { Mesenchymal Stromal } \\
\text { Cells }\end{array}$ & Sep-15 \\
\hline $\begin{array}{l}\text { NCT } \\
0184 \\
9237\end{array}$ & $\begin{array}{l}\text { Russian Clinical Trial } \\
\text { of Mesenchymal Cells } \\
\text { in Patients With Septic } \\
\text { Shock and Severe } \\
\text { Neutropenia }\end{array}$ & $\begin{array}{l}\text { Septic Shock| } \\
\text { Nonchemotherapy } \\
\text { Drug-induced } \\
\text { Neutropenia| } \\
\text { Neutropenia After } \\
\text { Chemotherapy in } \\
\text { Oncohematological } \\
\text { Patients| } \\
\text { Neutropenia in } \\
\text { Patients With } \\
\text { Aplastic Anemia }\end{array}$ & $\begin{array}{l}\text { Genetic: } \\
\text { Mesenchymal stromal } \\
\text { cells|Drug: Standard } \\
\text { therapy of septic } \\
\text { shock }\end{array}$ & May-13 \\
\hline $\begin{array}{l}\text { NCT } \\
0238 \\
7151\end{array}$ & $\begin{array}{l}\text { Allogeneic } \\
\text { Mesenchymal Stromal } \\
\text { Cell Therapy in Renal } \\
\text { Transplant Recipients }\end{array}$ & $\begin{array}{l}\text { Rejection|Graft } \\
\text { Loss }\end{array}$ & $\begin{array}{l}\text { Procedure: } \\
\text { mesenchymal stem } \\
\text { cell infusion }\end{array}$ & Mar-15 \\
\hline $\begin{array}{l}\text { NCT } \\
0117 \\
5655\end{array}$ & $\begin{array}{l}\text { A Study to Evaluate } \\
\text { the Potential of } \\
\text { Mesenchymal Stromal } \\
\text { Cells to Treat } \\
\text { Obliterative } \\
\text { Bronchiolitis After Lung } \\
\text { Transplantation }\end{array}$ & $\begin{array}{l}\text { Bronchiolitis } \\
\text { Obliterans|Lung } \\
\text { Transplantation }\end{array}$ & Other: MSC & Apr-15 \\
\hline $\begin{array}{l}\text { NCT } \\
0095 \\
7931\end{array}$ & $\begin{array}{l}\text { Allo-HCT MUD for } \\
\text { Non-malignant Red } \\
\text { Blood Cell (RBC) } \\
\text { Disorders: Sickle Cell, } \\
\text { Thal, and DBA: } \\
\text { Reduced Intensity }\end{array}$ & $\begin{array}{l}\text { Sickle Cell } \\
\text { Disease| } \\
\text { Thalassemia| } \\
\text { Diamond-Blackfan } \\
\text { Anemia }\end{array}$ & $\begin{array}{l}\text { Procedure: Bone } \\
\text { marrow } \\
\text { transplantation| } \\
\text { Biological: } \\
\text { Mesenchymal Stromal } \\
\text { Cells }\end{array}$ & Dec-12 \\
\hline
\end{tabular}




\begin{tabular}{|c|c|c|c|c|}
\hline & $\begin{array}{l}\text { Conditioning, Co-tx } \\
\text { MSCs }\end{array}$ & & & \\
\hline $\begin{array}{l}\text { NCT } \\
0174 \\
2260\end{array}$ & $\begin{array}{l}\text { Cranial Reconstruction } \\
\text { Using Mesenchymal } \\
\text { Stromal Cells and } \\
\text { Resorbable } \\
\text { Biomaterials }\end{array}$ & $\begin{array}{l}\text { Surgically-Created } \\
\text { Resection Cavity }\end{array}$ & $\begin{array}{l}\text { Procedure: Repair of } \\
\text { cranial defects by } \\
\text { tissue engineering }\end{array}$ & Jun-15 \\
\hline $\begin{array}{l}\text { NCT } \\
0226 \\
0375\end{array}$ & $\begin{array}{l}\text { MSC Therapy in Liver } \\
\text { Transplantation }\end{array}$ & $\begin{array}{l}\text { Liver Transplant } \\
\text { Rejection }\end{array}$ & $\begin{array}{l}\text { Biological: } \\
\text { Mesenchymal Stromal } \\
\text { Cells }\end{array}$ & Sep-15 \\
\hline $\begin{array}{l}\text { NCT } \\
0187 \\
2624\end{array}$ & $\begin{array}{l}\text { Safety Study of Bone- } \\
\text { marrow Derived } \\
\text { Mesenchymal Stromal } \\
\text { Cells Associated With } \\
\text { Endobronchial Valves } \\
\text { in Emphysema }\end{array}$ & $\begin{array}{l}\text { Pulmonary } \\
\text { Emphysema }\end{array}$ & $\begin{array}{l}\text { Procedure: } \\
\text { Bronchoscopy }\end{array}$ & Mar-15 \\
\hline $\begin{array}{l}\text { NCT } \\
0158 \\
6312\end{array}$ & $\begin{array}{l}\text { Treatment of Knee } \\
\text { Osteoarthritis With } \\
\text { Allogenic } \\
\text { Mesenchymal Stem } \\
\text { Cells }\end{array}$ & $\begin{array}{l}\text { Osteoarthritis, } \\
\text { Knee|Arthritis of } \\
\text { Knee|Knee } \\
\text { Osteoarthritis }\end{array}$ & $\begin{array}{l}\text { Other: Allogenic } \\
\text { mesenchymal stromal } \\
\text { cells injection|Drug: } \\
\text { Hyaluronic Acid }\end{array}$ & Sep-15 \\
\hline $\begin{array}{l}\text { NCT } \\
0186 \\
0417\end{array}$ & $\begin{array}{l}\text { Treatment of } \\
\text { Degenerative Disc } \\
\text { Disease With Allogenic } \\
\text { Mesenchymal Stem } \\
\text { Cells (MSV) }\end{array}$ & $\begin{array}{l}\text { Degenerative Disc } \\
\text { Disease| } \\
\text { Intervertebral Disc } \\
\text { Disease|Low Back } \\
\text { Pain }\end{array}$ & $\begin{array}{l}\text { Biological: Allogenic } \\
\text { Mesenchymal Stromal } \\
\text { Cells| Drug: } \\
\text { Mepivacaine }\end{array}$ & Sep-15 \\
\hline $\begin{array}{l}\text { NCT } \\
0238 \\
4018\end{array}$ & $\begin{array}{l}\text { Mesenchymal Stem } \\
\text { Cell and Islet } \\
\text { Co-transplantation }\end{array}$ & $\begin{array}{l}\text { Chronic } \\
\text { Pancreatitis| } \\
\text { Diabetes }\end{array}$ & $\begin{array}{l}\text { Biological: autologous } \\
\text { mesenchymal stromal } \\
\text { cell }\end{array}$ & Dec-14 \\
\hline $\begin{array}{l}\text { NCT } \\
0130 \\
6513\end{array}$ & $\begin{array}{l}\text { Safety and Feasibility } \\
\text { Study of Administration } \\
\text { of Mesenchymal Stem } \\
\text { Cells for Treatment of } \\
\text { Emphysema }\end{array}$ & Emphysema & $\begin{array}{l}\text { Biological: autologous } \\
\text { bone marrow derived } \\
\text { mesenchymal stromal } \\
\text { cells }\end{array}$ & Nov-12 \\
\hline $\begin{array}{l}\text { NCT } \\
0235 \\
9929\end{array}$ & $\begin{array}{l}\text { BMT Auto MSCs GvHD } \\
\text { Ph1 }\end{array}$ & $\begin{array}{l}\text { Graft Versus Host } \\
\text { Disease|Acute } \\
\text { Graft Versus Host } \\
\text { Disease|Chronic } \\
\text { Graft Versus Host } \\
\text { Disease }\end{array}$ & $\begin{array}{l}\text { Biological: Autologous } \\
\text { mesenchymal stromal } \\
\text { cells (MSCs) }\end{array}$ & Aug-15 \\
\hline $\begin{array}{l}\text { NCT } \\
0258 \\
5622 \\
\end{array}$ & $\begin{array}{l}\text { Novel Stromal Cell } \\
\text { Therapy for Diabetic } \\
\text { Kidney Disease }\end{array}$ & $\begin{array}{l}\text { Diabetic Kidney } \\
\text { Disease }\end{array}$ & $\begin{array}{l}\text { Biological: } \\
\text { Mesenchymal Stromal } \\
\text { Cells| Other: Placebo }\end{array}$ & Oct-15 \\
\hline
\end{tabular}




\begin{tabular}{|c|c|c|c|c|}
\hline $\begin{array}{l}\text { NCT } \\
0203 \\
3525\end{array}$ & $\begin{array}{l}\text { Mesenchymal Stromal } \\
\text { Cells for Degenerative } \\
\text { Meniscus Injury }\end{array}$ & $\begin{array}{l}\text { Chronic Meniscal } \\
\text { Injury }\end{array}$ & $\begin{array}{l}\text { Drug: XCEL-M- } \\
\text { ALPHA and standard } \\
\text { rehabilitation| Other: } \\
\text { Rehabilitation }\end{array}$ & Jul-15 \\
\hline $\begin{array}{l}\text { NCT } \\
0258 \\
9119\end{array}$ & $\begin{array}{l}\text { Stem Cell Fistula Plug } \\
\text { in Cryptoglandular } \\
\text { Perianal Fistulas } \\
\text { (MSC-AFP) }\end{array}$ & $\begin{array}{l}\text { Perianal Fistula| } \\
\text { Cryptoglandular } \\
\text { Perianal Fistula }\end{array}$ & Drug: MSC-AFP & Oct-15 \\
\hline $\begin{array}{l}\text { NCT } \\
0242 \\
1484\end{array}$ & $\begin{array}{l}\text { Cellular } \\
\text { Immunotherapy for } \\
\text { Septic Shock: A Phase } \\
\text { I Trial }\end{array}$ & Septic Shock & $\begin{array}{l}\text { Biological: Allogeneic } \\
\text { bone marrow derived } \\
\text { mesenchymal stromal } \\
\text { cells }\end{array}$ & Apr-15 \\
\hline $\begin{array}{l}\text { NCT } \\
0205 \\
5625\end{array}$ & $\begin{array}{l}\text { Mesenchymal Stem } \\
\text { Cells as a Treatment } \\
\text { for Oral Complications } \\
\text { of Graft-versus-host } \\
\text { Disease }\end{array}$ & $\begin{array}{l}\text { Graft -Versus-host- } \\
\text { disease }\end{array}$ & $\begin{array}{l}\text { Biological: } \\
\text { Mesenchymal stromal } \\
\text { cells }\end{array}$ & Mar-15 \\
\hline $\begin{array}{l}\text { NCT } \\
0240 \\
8432\end{array}$ & $\begin{array}{l}\text { Intravenous } \\
\text { Administration of } \\
\text { Allogeneic Bone } \\
\text { Marrow Derived } \\
\text { Multipotent } \\
\text { Mesenchymal Stromal } \\
\text { Cells (MSCs) in } \\
\text { Patients With Recent } \\
\text { Onset Anthracycline- } \\
\text { Associated } \\
\text { Cardiomyopathy }\end{array}$ & Cardiomyopathy & $\begin{array}{l}\text { Biological: Human } \\
\text { Mesenchymal Stem } \\
\text { Cells (hMSCs)|Other: } \\
\text { Standard of Care }\end{array}$ & Jun-15 \\
\hline $\begin{array}{l}\text { NCT } \\
0218 \\
1478\end{array}$ & $\begin{array}{l}\text { Intra-Osseous Co- } \\
\text { Transplant of UCB and } \\
\text { hMSC }\end{array}$ & $\begin{array}{l}\text { Acute } \\
\text { Lymphoblastic } \\
\text { Leukemia| Acute } \\
\text { Myelogenous } \\
\text { Leukemia| } \\
\text { Myelodysplastic } \\
\text { Syndromes| } \\
\text { Myelofibrosis| } \\
\text { Relapsed Non- } \\
\text { Hodgkin } \\
\text { Lymphoma| } \\
\text { Refractory Non- } \\
\text { Hodgkin } \\
\text { Lymphoma| } \\
\text { Hodgkin } \\
\text { Lymphoma| } \\
\text { Refractory Hodgkin } \\
\text { Lymphoma| }\end{array}$ & $\begin{array}{l}\text { Drug: } \\
\text { cyclophosphamide| } \\
\text { Drug: fludarabine } \\
\text { phosphate| Radiation: } \\
\text { total-body } \\
\text { irradiation|Drug: } \\
\text { cyclosporine|Drug: } \\
\text { mycophenolate } \\
\text { mofetil|Procedure: } \\
\text { umbilical cord blood } \\
\text { transplantation| } \\
\text { Procedure: } \\
\text { mesenchymal stem } \\
\text { cell transplantation }\end{array}$ & Jul-15 \\
\hline
\end{tabular}




\begin{tabular}{|c|c|c|c|c|}
\hline & & $\begin{array}{l}\text { Relapsed Chronic } \\
\text { Lymphocytic } \\
\text { Leukemia| } \\
\text { Refractory Chronic } \\
\text { Lymphocytic } \\
\text { Leukemia| } \\
\text { Lymphoid } \\
\text { Malignancies| } \\
\text { Chronic } \\
\text { Myelogenous } \\
\text { Leukemia }\end{array}$ & & \\
\hline $\begin{array}{l}\text { NCT } \\
0235 \\
1011\end{array}$ & $\begin{array}{l}\text { Human Autologous } \\
\text { MSCs for the } \\
\text { Treatment of Mid to } \\
\text { Late Stage Knee OA }\end{array}$ & $\begin{array}{l}\text { Osteoarthritis of } \\
\text { Knee }\end{array}$ & $\begin{array}{l}\text { Biological: } 1 \times 10^{\wedge} 6 \\
\text { MSCs|Biological: } 10 \mathrm{x} \\
10^{\wedge} 6 \text { MSCs|Biological: } \\
50 \times 10^{\wedge} 6 \text { MSCs }\end{array}$ & Feb-15 \\
\hline $\begin{array}{l}\text { NCT } \\
0227 \\
0307\end{array}$ & $\begin{array}{l}\text { MSC and } \\
\text { Cyclophosphamide for } \\
\text { Acute Graft-Versus- } \\
\text { Host Disease (aGVHD) } \\
\text { Prophylaxis }\end{array}$ & $\begin{array}{l}\text { Leukemia| Multiple } \\
\text { Myeloma }\end{array}$ & $\begin{array}{l}\text { Drug: } \\
\text { Cyclophosphamide| } \\
\text { Biological: } \\
\text { Mesenchymal stromal } \\
\text { cells }\end{array}$ & Oct-14 \\
\hline $\begin{array}{l}\text { NCT } \\
0192 \\
2908\end{array}$ & $\begin{array}{l}\text { Mesenchymal Stromal } \\
\text { Cells for Ischemic } \\
\text { Stroke }\end{array}$ & Ischemic Stroke & $\begin{array}{l}\text { Biological: MSC } \\
\text { Infusion|Biological: } \\
\text { Placebo Comparator }\end{array}$ & May-15 \\
\hline $\begin{array}{l}\text { NCT } \\
0214 \\
5923\end{array}$ & $\begin{array}{l}\text { Effectiveness and } \\
\text { Safety of MMSCs for } \\
\text { Enhancing } \\
\text { Hematopoietic } \\
\text { Recovery and } \\
\text { Prophylaxis of } \\
\text { Neutropenic } \\
\text { Enterocolitis }\end{array}$ & $\begin{array}{l}\text { Neutropenic } \\
\text { Enterocolitis| } \\
\text { Myeloablative } \\
\text { Chemotherapy } \\
\text { Induced Bone } \\
\text { Marrow Aplasia }\end{array}$ & $\begin{array}{l}\text { Procedure: Peripheral } \\
\text { blood stem cell } \\
\text { mobilisation and } \\
\text { collection|Drug: High- } \\
\text { dose chemotherapy| } \\
\text { Drug: Bone marrow } \\
\text { derived allogeneic } \\
\text { MMSCs } \\
\text { infusion|Procedure: } \\
\text { Autologous peripheral } \\
\text { blood stem cells } \\
\text { infusion }\end{array}$ & Jun-15 \\
\hline $\begin{array}{l}\text { NCT } \\
0127 \\
5612\end{array}$ & $\begin{array}{l}\text { Mesenchymal Stem } \\
\text { Cells In Cisplatin- } \\
\text { Induced Acute Renal } \\
\text { Failure In Patients With } \\
\text { Solid Organ Cancers }\end{array}$ & $\begin{array}{l}\text { Solid Tumors| } \\
\text { Acute Kidney Injury }\end{array}$ & $\begin{array}{l}\text { Biological: } \\
\text { Mesenchymal stromal } \\
\text { cell infusion }\end{array}$ & Oct-15 \\
\hline
\end{tabular}




\begin{tabular}{|c|c|c|c|c|}
\hline $\begin{array}{l}\text { NCT } \\
0190 \\
9154\end{array}$ & $\begin{array}{l}\text { Safety Study of Local } \\
\text { Administration of } \\
\text { Autologous Bone } \\
\text { Marrow Stromal Cells } \\
\text { in Chronic Paraplegia }\end{array}$ & Spinal Cord Injury & $\begin{array}{l}\text { Biological: } \\
\text { Mesenchymal stromal } \\
\text { cell therapy }\end{array}$ & Nov-13 \\
\hline $\begin{array}{l}\text { NCT } \\
0039 \\
5200\end{array}$ & $\begin{array}{l}\text { Mesenchymal Stem } \\
\text { Cells in Multiple } \\
\text { Sclerosis (MSCIMS) }\end{array}$ & Multiple Sclerosis & $\begin{array}{l}\text { Procedure: MSC } \\
\text { Treatment }\end{array}$ & Oct-11 \\
\hline $\begin{array}{l}\text { NCT } \\
0026 \\
0338\end{array}$ & $\begin{array}{l}\text { Stem Cell Therapy for } \\
\text { Vasculogenesis in } \\
\text { Patients With Severe } \\
\text { Myocardial Ischemia }\end{array}$ & $\begin{array}{l}\text { Myocardial } \\
\text { Ischemia| Coronary } \\
\text { Heart Disease }\end{array}$ & Biological: stem cell & May-13 \\
\hline $\begin{array}{l}\text { NCT } \\
0165 \\
9762\end{array}$ & $\begin{array}{l}\text { A Phase I Study } \\
\text { Evaluating Autologous } \\
\text { Bone Marrow Derived } \\
\text { Mesenchymal Stromal } \\
\text { for Crohn's Disease. }\end{array}$ & Crohn's Disease & $\begin{array}{l}\text { Biological: autologous } \\
\text { mesenchymal stromal } \\
\text { cell }\end{array}$ & Jul-15 \\
\hline $\begin{array}{l}\text { NCT } \\
0238 \\
2874\end{array}$ & $\begin{array}{l}\text { Allogenic AD-MSC } \\
\text { Transplantation in } \\
\text { Idiopathic Nephrotic } \\
\text { Syndrome (Focal } \\
\text { Segmental } \\
\text { Glomerulosclerosis) }\end{array}$ & $\begin{array}{l}\text { Focal Segmental } \\
\text { Glomerulosclerosis }\end{array}$ & $\begin{array}{l}\text { Biological: Intravenous } \\
\text { injection }\end{array}$ & Mar-15 \\
\hline $\begin{array}{l}\text { NCT } \\
0244 \\
8849\end{array}$ & $\begin{array}{l}\text { Autologous BM-MSC } \\
\text { Transplantation in } \\
\text { Combination With } \\
\text { Platelet Lysate (PL) for } \\
\text { Nonunion Treatment }\end{array}$ & Bone Fracture & $\begin{array}{l}\text { Biological: } \\
\text { Percutaneous } \\
\text { injection| Other: } \\
\text { Percutaneous } \\
\text { injection }\end{array}$ & Sep-15 \\
\hline $\begin{array}{l}\text { NCT } \\
0191 \\
5927\end{array}$ & $\begin{array}{l}\text { Stem Cell Fistula Plug } \\
\text { in Perianal Crohn's } \\
\text { Disease }\end{array}$ & $\begin{array}{l}\text { Perianal Crohn's } \\
\text { Disease }\end{array}$ & Drug: MSC-AFP & Jun-15 \\
\hline $\begin{array}{l}\text { NCT } \\
0168 \\
6139\end{array}$ & $\begin{array}{l}\text { Safety Study of Stem } \\
\text { Cells Treatment in } \\
\text { Diabetic Foot Ulcers }\end{array}$ & $\begin{array}{l}\text { Type I Diabetes } \\
\text { Mellitus With Ulcer| } \\
\text { Type II Diabetes } \\
\text { Mellitus With Ulcer }\end{array}$ & $\begin{array}{l}\text { Biological: ABMD- } \\
\text { MSC }\end{array}$ & Jan-14 \\
\hline $\begin{array}{l}\text { NCT } \\
0201 \\
7912\end{array}$ & $\begin{array}{l}\text { Phase 2, Randomized, } \\
\text { Double Blind, Placebo } \\
\text { Controlled Multicenter } \\
\text { Study of Autologous } \\
\text { MSC-NTF Cells in } \\
\text { Patients With ALS }\end{array}$ & $\begin{array}{l}\text { Amyotrophic } \\
\text { Lateral Sclerosis } \\
\text { (ALS) }\end{array}$ & $\begin{array}{l}\text { Biological: Autologous } \\
\text { MSC-NTF cells }\end{array}$ & Jul-15 \\
\hline $\begin{array}{l}\text { NCT } \\
0146 \\
3475\end{array}$ & $\begin{array}{l}\text { University of Wisconsin } \\
\text { hMSC Cell Bank: Bone } \\
\text { Marrow Donor Protocol }\end{array}$ & $\begin{array}{l}\text { Graft Versus Host } \\
\text { Disease } \\
\text { (GVHD)|Acute } \\
\text { Myocardial } \\
\text { Infarction (AMI) }\end{array}$ & $\begin{array}{l}\text { Procedure: Bone } \\
\text { marrow aspirate }\end{array}$ & Dec-14 \\
\hline
\end{tabular}




\begin{tabular}{|c|c|c|c|c|}
\hline $\begin{array}{l}\text { NCT } \\
0219 \\
5323\end{array}$ & $\begin{array}{l}\text { Autologous Bone } \\
\text { Marrow Derived } \\
\text { Mesenchymal Stromal } \\
\text { Cells (BM-MSCs) in } \\
\text { Patients With Chronic } \\
\text { Kidney Disease (CKD) }\end{array}$ & $\begin{array}{l}\text { Chronic Kidney } \\
\text { Disease }\end{array}$ & $\begin{array}{l}\text { Biological: Intravenous } \\
\text { injection }\end{array}$ & Oct-13 \\
\hline $\begin{array}{l}\text { NCT } \\
0240 \\
9940\end{array}$ & $\begin{array}{l}\text { To Elucidate the Effect } \\
\text { of Mesenchymal Stem } \\
\text { Cells on the T Cell } \\
\text { Repertoire of the } \\
\text { Kidney Transplant } \\
\text { Patients }\end{array}$ & $\begin{array}{l}\text { Renal Transplant } \\
\text { Rejection }\end{array}$ & $\begin{array}{l}\text { Biological: } \\
\text { Mesenchymal Stem } \\
\text { Cells }\end{array}$ & Apr-15 \\
\hline $\begin{array}{l}\text { NCT } \\
0090 \\
8856\end{array}$ & $\begin{array}{l}\text { Autologous Cell } \\
\text { Therapy After Stroke }\end{array}$ & Stroke & $\begin{array}{l}\text { Biological: autologous } \\
\text { bone marrow } \\
\text { mononuclear cell } \\
\text { transfusion| Biological: } \\
\text { marrow stromal cells| } \\
\text { Drug: placebo }\end{array}$ & Dec-14 \\
\hline $\begin{array}{l}\text { NCT } \\
0224 \\
7973\end{array}$ & $\begin{array}{l}\text { Mesenchymal Stem } \\
\text { Cells Co-- } \\
\text { transplantation in } \\
\text { Alternative Donor } \\
\text { Transplantation of } \\
\text { Severe Aplastic } \\
\text { Anemia. }\end{array}$ & $\begin{array}{l}\text { Severe Aplastic } \\
\text { Anemia }\end{array}$ & $\begin{array}{l}\text { Biological: } \\
\text { mesenchymal stem } \\
\text { cells| Biological: } \\
\text { mesenchymal stem } \\
\text { cells }\end{array}$ & Sep-14 \\
\hline $\begin{array}{l}\text { NCT } \\
0144 \\
6614\end{array}$ & $\begin{array}{l}\text { Mesenchymal Stem } \\
\text { Cells Transplantation } \\
\text { to Patients With } \\
\text { Parkinson's Disease }\end{array}$ & $\begin{array}{l}\text { Parkinson's } \\
\text { Disease }\end{array}$ & $\begin{array}{l}\text { Biological: bone } \\
\text { marrow derived } \\
\text { mesenchymal stem } \\
\text { cells }\end{array}$ & Oct-11 \\
\hline $\begin{array}{l}\text { NCT } \\
0144 \\
6640\end{array}$ & $\begin{array}{l}\text { Mesenchymal Stem } \\
\text { Cells Transplantation } \\
\text { to Patients With Spinal } \\
\text { Cord Injury }\end{array}$ & Spinal Cord Injury & $\begin{array}{l}\text { Biological: bone } \\
\text { marrow derived } \\
\text { mesenchymal stem } \\
\text { cells }\end{array}$ & Oct-11 \\
\hline $\begin{array}{l}\text { NCT } \\
0130 \\
5694\end{array}$ & $\begin{array}{l}\text { Mesenchymal Stem } \\
\text { Cells Transplantation } \\
\text { to Patients With } \\
\text { Relapsed/Refractory } \\
\text { Aplastic Anemia. }\end{array}$ & Aplastic Anemia & $\begin{array}{l}\text { Biological: bone } \\
\text { marrow derived } \\
\text { mesenchymal stem } \\
\text { cells }\end{array}$ & Feb-11 \\
\hline $\begin{array}{l}\text { NCT } \\
0105 \\
1882\end{array}$ & $\begin{array}{l}\text { Autologous Cultured } \\
\text { Mesenchymal Bone } \\
\text { Marrow Stromal Cells } \\
\text { Secreting Neurotrophic } \\
\text { Factors (MSC-NTF), in } \\
\text { ALS Patients. }\end{array}$ & $\begin{array}{l}\text { Amyotrophic } \\
\text { Lateral Sclerosis }\end{array}$ & $\begin{array}{l}\text { Biological: MSC-NTF } \\
\text { cells transplantation } \\
\text { (i.m.)| Biological: } \\
\text { MSC-NTF cells } \\
\text { transplantation (i.t.) }\end{array}$ & Aug-12 \\
\hline
\end{tabular}




\begin{tabular}{|c|c|c|c|c|}
\hline $\begin{array}{l}\text { NCT } \\
0162 \\
4701\end{array}$ & $\begin{array}{l}\text { Clinical Ex Vivo } \\
\text { Expansion of Human } \\
\text { Umbilical Cord Blood } \\
\text { Stem and Progenitor } \\
\text { Cells }\end{array}$ & $\begin{array}{l}\text { Acute Leukemia| } \\
\text { Chronic Leukemia| } \\
\text { Myelodysplastic } \\
\text { Syndrome| } \\
\text { Lymphoma| } \\
\text { Myeloma }\end{array}$ & $\begin{array}{l}\text { Other: Ex-vivo } \\
\text { expanded cord blood } \\
\text { cells }\end{array}$ & Jun-12 \\
\hline $\begin{array}{l}\text { NCT } \\
0233 \\
6230\end{array}$ & $\begin{array}{l}\text { A Prospective Study of } \\
\text { Remestemcel-L, Ex- } \\
\text { vivo Cultured Adult } \\
\text { Human Mesenchymal } \\
\text { Stromal Cells, for the } \\
\text { Treatment of Pediatric } \\
\text { Patients Who Have } \\
\text { Failed to Respond to } \\
\text { Steroid Treatment for } \\
\text { Acute GVHD }\end{array}$ & $\begin{array}{l}\text { Grades B-D } \\
\text { aGVHD }\end{array}$ & Drug: Remestemcel-L & Jan-15 \\
\hline $\begin{array}{l}\text { NCT } \\
0252 \\
5432\end{array}$ & $\begin{array}{l}\text { Autologous Stem Cell } \\
\text { Study for Adult TBI } \\
\text { (Phase 2b) }\end{array}$ & $\begin{array}{l}\text { Brain Injuries, } \\
\text { Traumatic| Brain } \\
\text { Injuries, Acute| TBI } \\
\text { (Traumatic Brain } \\
\text { Injury) }\end{array}$ & $\begin{array}{l}\text { Biological: Placebo } \\
\text { Infusion| Biological: } \\
\text { Autologous BMMNC } \\
\text { Infusion| Device: } \\
\text { Ultrasound }\end{array}$ & Oct-15 \\
\hline $\begin{array}{l}\text { NCT } \\
0220 \\
9311\end{array}$ & $\begin{array}{l}\text { Effectiveness and } \\
\text { Safety of Method of } \\
\text { Maxilla Alveolar } \\
\text { Process } \\
\text { Reconstruction Using } \\
\text { Synthetic Tricalcium } \\
\text { Phosphate and } \\
\text { Autologous MMSCs } \\
\end{array}$ & $\begin{array}{l}\text { Partially } \\
\text { Edentulous Maxilla| } \\
\text { Alveolar Bone } \\
\text { Atrophy| Alveolar } \\
\text { Bone Loss }\end{array}$ & $\begin{array}{l}\text { Procedure: Oral } \\
\text { mucosa biopsy| } \\
\text { Procedure: Sinus lift } \\
\text { with implantation of } \\
\text { tissue engineered } \\
\text { construction| Device: } \\
\text { Dental implant }\end{array}$ & Sep-15 \\
\hline $\begin{array}{l}\text { NCT } \\
0237 \\
9442\end{array}$ & $\begin{array}{l}\text { Early Treatment of } \\
\text { Acute Graft Versus } \\
\text { Host Disease With } \\
\text { Bone Marrow-Derived } \\
\text { Mesenchymal Stem } \\
\text { Cells and } \\
\text { Corticosteroids }\end{array}$ & $\begin{array}{l}\text { Graft-Versus-Host } \\
\text { Disease }\end{array}$ & Biological: MSC & Feb-15 \\
\hline $\begin{array}{l}\text { NCT } \\
0114 \\
4962\end{array}$ & $\begin{array}{l}\text { Dose-escalating } \\
\text { Therapeutic Study of } \\
\text { Allogeneic Bone } \\
\text { Marrow Derived } \\
\text { Mesenchymal Stem } \\
\text { Cells for the Treatment } \\
\text { of Fistulas in Patients } \\
\text { With Refractory } \\
\text { Perianal Crohn's } \\
\text { Disease }\end{array}$ & $\begin{array}{l}\text { Crohn's Disease| } \\
\text { Fistula }\end{array}$ & $\begin{array}{l}\text { Procedure: } \\
\text { Localization, curettage } \\
\text { of the fistulous tract } \\
\text { and closure of the } \\
\text { internal opening } \\
\text { without MSC } \\
\text { injection.| Procedure: } \\
\text { Localization, curettage } \\
\text { of the fistulous tract } \\
\text { and closure of the }\end{array}$ & Dec-14 \\
\hline
\end{tabular}




\begin{tabular}{|c|c|c|c|c|}
\hline & & & $\begin{array}{l}\text { internal opening with } \\
\text { local MSC injection. }\end{array}$ & \\
\hline $\begin{array}{l}\text { NCT } \\
0244 \\
8121\end{array}$ & $\begin{array}{l}\text { Autologous Bone } \\
\text { Marrow Stem Cell } \\
\text { Transplantation for Hip } \\
\text { Osteonecrosis in Sickle } \\
\text { Cell Disease }\end{array}$ & $\begin{array}{l}\text { Avascular Necrosis } \\
\text { of Femur Head| } \\
\text { Sickle Cell Disease }\end{array}$ & $\begin{array}{l}\text { Procedure: Stem Cell } \\
\text { Graft Group| } \\
\text { Biological: Autologous } \\
\text { bone marrow stem cell }\end{array}$ & Aug-15 \\
\hline $\begin{array}{l}\text { NCT } \\
0189 \\
2514\end{array}$ & $\begin{array}{l}\text { Randomized Clinical } \\
\text { Trial for the Treatment } \\
\text { of Osteonecrosis of the } \\
\text { Femoral Head }\end{array}$ & Osteonecrosis & $\begin{array}{l}\text { Procedure: core } \\
\text { decompression }\end{array}$ & Apr-14 \\
\hline $\begin{array}{l}\text { NCT } \\
0224 \\
9676\end{array}$ & $\begin{array}{l}\text { Autologous } \\
\text { Mesenchymal Stem } \\
\text { Cells for the Treatment } \\
\text { of Neuromyelitis Optica } \\
\text { Spectrum Disorders }\end{array}$ & $\begin{array}{l}\text { Devic's Syndrome| } \\
\text { Devic's } \\
\text { Neuromyelitis } \\
\text { Optica| Devic } \\
\text { Syndrome| Devic's } \\
\text { Disease| Devic } \\
\text { Disease }\end{array}$ & $\begin{array}{l}\text { Biological: Autologous } \\
\text { mesenchymal stem } \\
\text { cells }\end{array}$ & Sep-14 \\
\hline $\begin{array}{l}\text { NCT } \\
0248 \\
2194\end{array}$ & $\begin{array}{l}\text { Autologous } \\
\text { Mesenchymal Stem } \\
\text { Cells Transplantation } \\
\text { for Spinal Cord Injury- } \\
\text { A Phase I Clinical } \\
\text { Study }\end{array}$ & Spinal Cord Injury & $\begin{array}{l}\text { Biological: } \\
\text { mesenchymal stem } \\
\text { cells }\end{array}$ & Jun-15 \\
\hline $\begin{array}{l}\text { NCT } \\
0073 \\
1744\end{array}$ & $\begin{array}{l}\text { Generation of Dendritic } \\
\text { Cell Precursors From } \\
\text { Cord Blood Stem Cells }\end{array}$ & $\begin{array}{l}\text { Normal Full-Term } \\
\text { Deliveries }\end{array}$ & $\begin{array}{l}\text { Procedure: Normal } \\
\text { full-term deliveries }\end{array}$ & Aug-08 \\
\hline $\begin{array}{l}\text { NCT } \\
0203 \\
7204\end{array}$ & $\begin{array}{l}\text { IMPACT: Safety and } \\
\text { Feasibility of a Single- } \\
\text { stage Procedure for } \\
\text { Focal Cartilage } \\
\text { Lesions of the Knee. }\end{array}$ & $\begin{array}{l}\text { Foreign-Body } \\
\text { Reaction| } \\
\text { Inflammation| } \\
\text { Effusion (L) Knee| } \\
\text { Knee Pain Swelling }\end{array}$ & $\begin{array}{l}\text { Other: Cartilage repair } \\
\text { surgery }\end{array}$ & Jul-14 \\
\hline $\begin{array}{l}\text { NCT } \\
0199 \\
3368\end{array}$ & $\begin{array}{l}\text { Analysis of } \\
\text { Osteoimmune } \\
\text { Interactions Linking } \\
\text { Inflammation and Bone } \\
\text { Destruction in } \\
\text { Aggressive } \\
\text { Periodontitis } \\
\end{array}$ & $\begin{array}{l}\text { Aggressive } \\
\text { Periodontitis| } \\
\text { Chronic } \\
\text { Periodontitis }\end{array}$ & Other: flow cytometry & Sep-15 \\
\hline $\begin{array}{l}\text { NCT } \\
0177 \\
7646\end{array}$ & $\begin{array}{l}\text { Autologous Cultured } \\
\text { Mesenchymal Bone } \\
\text { Marrow Stromal Cells } \\
\text { Secreting Neurotrophic }\end{array}$ & $\begin{array}{l}\text { Amyotrophic } \\
\text { Lateral Sclerosis }\end{array}$ & $\begin{array}{l}\text { Biological: MSC_NTF } \\
\text { cells transplantation } \\
\text { by multiple } \\
\text { intramuscular }\end{array}$ & Jan-14 \\
\hline
\end{tabular}




\begin{tabular}{|c|c|c|c|c|}
\hline & $\begin{array}{l}\text { Factors (MSC-NTF), in } \\
\text { Patients With } \\
\text { Amyotrophic Lateral } \\
\text { Sclerosis (ALS) }\end{array}$ & & $\begin{array}{l}\text { injections at } 24 \\
\text { separate sites, in } \\
\text { addition to a single } \\
\text { intrathechal injection } \\
\text { into the CSF }\end{array}$ & \\
\hline $\begin{array}{l}\text { NCT } \\
0146 \\
8064\end{array}$ & $\begin{array}{l}\text { Autologous Bone } \\
\text { Marrow Stromal Cell } \\
\text { and Endothelial } \\
\text { Progenitor Cell } \\
\text { Transplantation in } \\
\text { Ischemic Stroke }\end{array}$ & $\begin{array}{l}\text { Stroke| Infarction, } \\
\text { Middle Cerebral } \\
\text { Artery }\end{array}$ & $\begin{array}{l}\text { Genetic: Autologous } \\
\text { BMSCs } \\
\text { transplantation| } \\
\text { Genetic: Autologous } \\
\text { EPCs transplantation| } \\
\text { Genetic: IV infusion of } \\
\text { placebo }\end{array}$ & Nov-15 \\
\hline $\begin{array}{l}\text { NCT } \\
0107 \\
1577\end{array}$ & $\begin{array}{l}\text { Collection of Bone } \\
\text { Marrow From Healthy } \\
\text { Volunteers and } \\
\text { Patients for the } \\
\text { Production of Clinical } \\
\text { Bone Marrow Stromal } \\
\text { Cell (BMSC) Products }\end{array}$ & $\begin{array}{l}\text { Bone Marrow| } \\
\text { Bone Marrow } \\
\text { Stromal Cells| } \\
\text { Mesenchymal } \\
\text { Stem Cells| Blood } \\
\text { Donors }\end{array}$ & & Aug-15 \\
\hline $\begin{array}{l}\text { NCT } \\
0018 \\
6914\end{array}$ & $\begin{array}{l}\text { Stromal Therapy of } \\
\text { Osteodysplasia After } \\
\text { Allogeneic Bone } \\
\text { Marrow } \\
\text { Transplantation }\end{array}$ & Osteodysplasia & $\begin{array}{l}\text { Biological: Marrow } \\
\text { stromal cell infusion }\end{array}$ & Feb-08 \\
\hline $\begin{array}{l}\text { NCT } \\
0078 \\
1872\end{array}$ & $\begin{array}{l}\text { Mesenchymal Stem } \\
\text { Cells for the Treatment } \\
\text { of MS }\end{array}$ & Multiple Sclerosis & $\begin{array}{l}\text { Biological: injection of } \\
\text { autologous stem cells }\end{array}$ & Oct-08 \\
\hline $\begin{array}{l}\text { NCT } \\
0246 \\
7387\end{array}$ & $\begin{array}{l}\text { A Study to Assess the } \\
\text { Effect of Intravenous } \\
\text { Dose of (aMBMC) to } \\
\text { Subjects With Non- } \\
\text { ischemic Heart Failure }\end{array}$ & $\begin{array}{l}\text { Non-Ischemic } \\
\text { Heart Failure }\end{array}$ & $\begin{array}{l}\text { Drug: Allogeneic } \\
\text { Mesenchymal Bone } \\
\text { Marrow Cells } \\
\text { (aMBMC)| Drug: } \\
\text { Lactated Ringer's } \\
\text { Solution }\end{array}$ & Jun-15 \\
\hline $\begin{array}{l}\text { NCT } \\
0244 \\
2817\end{array}$ & $\begin{array}{l}\text { Linagliptin and } \\
\text { Mesenchymal Stem } \\
\text { Cells: A Pilot Study }\end{array}$ & Schizophrenia & Drug: Linagliptin & Apr-15 \\
\hline $\begin{array}{l}\text { NCT } \\
0206 \\
4062\end{array}$ & $\begin{array}{l}\text { Autologous Stem Cells } \\
\text { in Achilles } \\
\text { Tendinopathy }\end{array}$ & $\begin{array}{l}\text { Achilles Tendinitis, } \\
\text { Right Leg| Achilles } \\
\text { Tendinitis| Achilles } \\
\text { Degeneration| } \\
\text { Achilles Tendon } \\
\text { Thickening| } \\
\text { Tendinopathy| } \\
\text { Achilles Tendinitis, } \\
\text { Left Leg }\end{array}$ & $\begin{array}{l}\text { Biological: Autologous } \\
\text { Mesenchymal Stem } \\
\text { Cells }\end{array}$ & Feb-14 \\
\hline
\end{tabular}




\begin{tabular}{|c|c|c|c|c|}
\hline $\begin{array}{l}\text { NCT } \\
0184 \\
0540\end{array}$ & $\begin{array}{l}\text { MSC for Occlusive } \\
\text { Disease of the Kidney }\end{array}$ & $\begin{array}{l}\text { Atherosclerotic } \\
\text { Renal Artery } \\
\text { Stenosis| Ischemic } \\
\text { Nephropathy| } \\
\text { Renovascular } \\
\text { Hypertension }\end{array}$ & $\begin{array}{l}\text { Drug: Arterial infusion } \\
\text { of autologous } \\
\text { mesenchymal stem } \\
\text { cells }\end{array}$ & Oct-15 \\
\hline $\begin{array}{l}\text { NCT } \\
0179 \\
5950\end{array}$ & $\begin{array}{l}\text { Safety Study of PLX- } \\
\text { PAD Cells to Treat } \\
\text { Pulmonary Arterial } \\
\text { Hypertension (PAH) }\end{array}$ & $\begin{array}{l}\text { Pulmonary Arterial } \\
\text { Hypertension }\end{array}$ & Drug: PLX-PAD & Sep-15 \\
\hline $\begin{array}{l}\text { NCT } \\
0137 \\
7870\end{array}$ & $\begin{array}{l}\text { Evaluation of } \\
\text { Autologous } \\
\text { Mesenchymal Stem } \\
\text { Cell Transplantation } \\
\text { (Effects and Side } \\
\text { Effects) in Multiple } \\
\text { Sclerosis }\end{array}$ & Multiple Sclerosis & $\begin{array}{l}\text { Biological: intravenous } \\
\text { injection of } \\
\text { mesenchymal stem } \\
\text { cells| Biological: } \\
\text { injection of cell free } \\
\text { media }\end{array}$ & Aug-10 \\
\hline $\begin{array}{l}\text { NCT } \\
0155 \\
7543\end{array}$ & $\begin{array}{l}\text { Stem Cell Injection to } \\
\text { Treat Heart Damage } \\
\text { During Open Heart } \\
\text { Surgery }\end{array}$ & $\begin{array}{l}\text { Heart Disease| } \\
\text { Ischemic Heart } \\
\text { Disease| Coronary } \\
\text { Artery Disease| } \\
\text { Coronary Artery } \\
\text { Disease (CAD) }\end{array}$ & Other: Cell Therapy & Nov-15 \\
\hline $\begin{array}{l}\text { NCT } \\
0091 \\
9958\end{array}$ & $\begin{array}{l}\text { Safety of Intramuscular } \\
\text { Injection of Allogeneic } \\
\text { PLX-PAD Cells for the } \\
\text { Treatment of Critical } \\
\text { Limb Ischemia }\end{array}$ & $\begin{array}{l}\text { Peripheral Artery } \\
\text { Disease| Peripheral } \\
\text { Vascular Disease| } \\
\text { Critical Limb } \\
\text { Ischemia }\end{array}$ & $\begin{array}{l}\text { Biological: PLX-PAD } \\
\text { IM injection }\end{array}$ & Jun-12 \\
\hline $\begin{array}{l}\text { NCT } \\
0095 \\
1210\end{array}$ & $\begin{array}{l}\text { Safety of Intramuscular } \\
\text { Injections (IM) of } \\
\text { Allogeneic PLX-PAD } \\
\text { Cells for the Treatment } \\
\text { of Critical Limb } \\
\text { Ischemia (CLI) }\end{array}$ & $\begin{array}{l}\text { Peripheral Artery } \\
\text { Disease| Peripheral } \\
\text { Vascular Disease| } \\
\text { Critical Limb } \\
\text { Ischemia }\end{array}$ & Biological: PLX-PAD & Nov-11 \\
\hline $\begin{array}{l}\text { NCT } \\
0232 \\
3477\end{array}$ & $\begin{array}{l}\text { Human Umbilical Cord } \\
\text { Stroma MSC in } \\
\text { Myocardial Infarction }\end{array}$ & $\begin{array}{l}\text { Chronic Ischemic } \\
\text { Cardiomyopathy| } \\
\text { Coronary Artery } \\
\text { Bypass Surgery }\end{array}$ & $\begin{array}{l}\text { Biological: stem cell } \\
\text { transplantation }\end{array}$ & May-15 \\
\hline $\begin{array}{l}\text { NCT } \\
0184 \\
9159\end{array}$ & $\begin{array}{l}\text { Clinical Study of the } \\
\text { Efficacy and Safety of } \\
\text { the Application of } \\
\text { Allogeneic } \\
\text { Mesenchymal } \\
\text { (Stromal) Cells of Bone } \\
\text { Marrow, Cultured } \\
\text { Under the Hypoxia in }\end{array}$ & $\begin{array}{l}\text { Pulmonary } \\
\text { Emphysema }\end{array}$ & $\begin{array}{l}\text { Biological: } \\
\text { Mesenchymal stem } \\
\text { cells| Other: } \\
\text { Reference therapy: } \\
400 \mathrm{~mL} \text { of } 0.9 \% \mathrm{NaCl} \\
\text { solution }\end{array}$ & Oct-15 \\
\hline
\end{tabular}




\begin{tabular}{|l|l|l|l|l|}
\hline & $\begin{array}{l}\text { the Treatment of } \\
\text { Patients With Severe } \\
\text { Pulmonary } \\
\text { Emphysema }\end{array}$ & & & \\
\hline NCT & Treatment of & Necrosis & & \\
0082 & Osteonecrosis of the & & Procedure: core & Jan-09 \\
1470 & Femoral Head by Bone & & decompression| & \\
& Marrow & Procedure: Bone \\
& marrow implantation & \\
into the necrotic lesion & \\
\hline NCT & Safety and Efficacy & Gastrointestinal & Drug: Imatinib & Mar-15 \\
0117 & Evaluation of Two Year & Stromal Tumors & mesylate & \\
2548 & Imatinib Treatment in & & & \\
& Adjuvant & & & \\
& Gastrointestinal & & & \\
& Stromal Tumor (GIST) & & & \\
\hline
\end{tabular}

Table.3.3.1 Mesenchymal Stromal cells (MSCs) clinical trials in various disorders as listed on www.ClinicalTrials.gov by the National Institute of Health (NIH) by Nov. 2015

\subsection{MESENCHYMAL STROMAL CELLS (MSCs) RADIO-}

\section{BIOLOGICAL RESPONSE}

The exposure of MSCs to ionizing radiation (IR) induces direct and indirect double stranded DNA breaks (DSB) which are detected by Poly (ADP-ribose) polymerase (PARP) and heterodimeric Ku protein complex (Ku70/80) sensor proteins [104, 106]. At the DSB location, PARP started the signal amplification upon formation of the Mre11, RAD50, and NBS-1 protein complex which leads to recruitment and autophosphorylation of Ataxia Telangectasia mutated protein (ATM). Phosphorylated ATM ( $p-A T M)$ is a main station that leads to multiple downstream signals. P-ATM enhances the phosphorylation of histone $\mathrm{H} 2 \mathrm{X}$ (to $\mathrm{y}-\mathrm{H} 2 \mathrm{AX}$ ) and DNA-PK (to $\mathrm{p}$-DNAPK), phosphorylates P53 (a tumor suppressor regulatory protein), activate the cell cycle checkpoint effector protein kinases (Chk-1 and Chk-2), and prepares for cell 
cycle arrest (G2/M). In addition to that, the Chk1 activation is augmented by the replication stress-mediated ATR pathway (through replication protein A, RPA), while the Chk2 activation is enhanced directly through Ku70/80-mediated p-DNA-PK signaling $[104,106]$. Cell division cycle phosphatase (Cdc25) is crucial for removing the inhibitory phosphorylation on specific residues on the cyclin-dependent kinase (Cdk). Chk1 phosphorylates Cdc25 in the presence of DNA damage resulting in the inhibition of Cdc25 activity. Chk1 and Chk2 are main inhibitors of Cdc25A and Cdc25C resulting in Cdk/cyclin-mediated cell cycle arrest [71]. It has been suggested that DSB in MSCs are repaired by activation of both the homologous recombination (HR, during $S$ and $\mathrm{G} 2$ phases) and the non-homologous end-joining (NHEJ, during all cell cycle phases) DNA repair pathways [95, 104, 106]. Our recent study showed the activation of HR and NHEJ repair pathways in irradiated aMSCs [159]. In addition, P-ATM enhances the stabilization of the tumor suppressor regulatory protein and transcription factor P53 which up-regulates the expression and enhances the stabilization of the transcription factor and inhibitory regulatory protein p21, which potently inhibits Cdks which are needed for the G1/S transition leading to inhibition of the entry into S phase [106].

The application of MSCs in radiation oncology regenerative medicine (RORM) was enhanced by their efficient radiation-induced DNA repair machinery and their relative radiation resistance $[91,95,96,99,159]$. Such radiation resistance was mediated by many mechanisms, e.g. the ATM phosphorylation, activation of cell cycle check points (G2/M arrest), and activation of single and double stranded DNA repair by both homologous and non-homologous recombination mechanisms and other 
pathways [95, 159] (Figure.3.4.1). DSB resulting from the direct and indirect radiation injury stimulate the phosphorylation of ATM which is the proximal step for cell cycle check point's activation (G2/M arrest). In addition to that, the nuclear apoptotic factor P84 (P84/53E10 = the nuclear protein encoded by the N5 gene) is up regulated, which participates in the apoptotic response of the aMSCs. It has been documented that irradiated aMSCs showed p-ATM dependent and p-ATM independent (P84-mediated) G2/M arrest [159]. Phosphorylated histone-2AX ( $\mathrm{Y}$ H2AX) stimulated both the HR and the NHEJ of the dsDNA breaks and other repair mechanisms [160]. Rad-51 is considered one of the mandatory proteins for HR to occur. DNA-PK is the major protein in the NHEJ repair pathway. Studies have shown that both proteins (Rad-51 and DNA-PK) were up regulated in irradiated MSCs (Figure.3.4.1) [95, 104, 159]. 


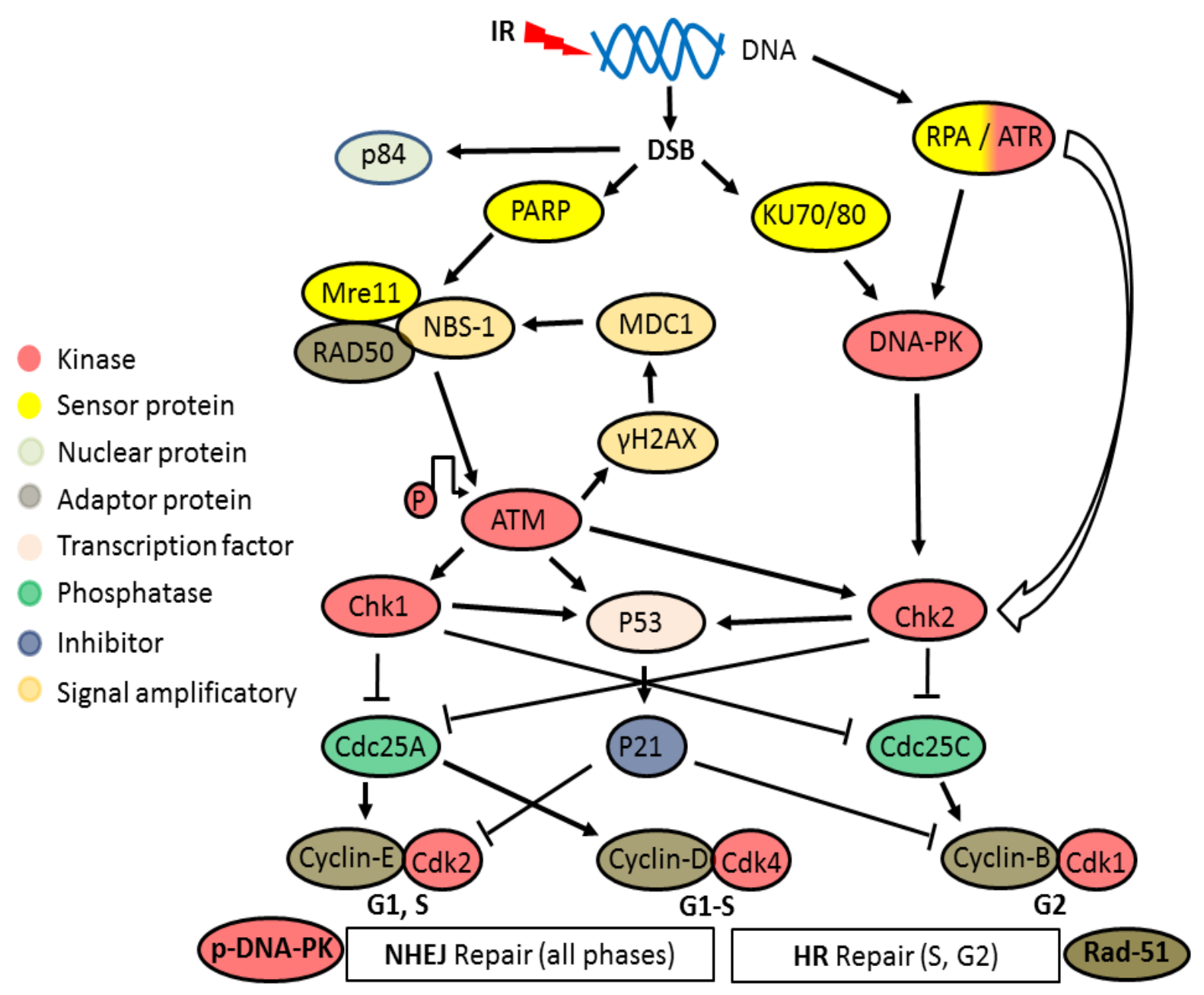

Figure.3.4.1: MSCs radiobiological response

Double stranded DNA (dsDNA) breaks (DSB) resulting from the direct and indirect radiation injury stimulate the phosphorylation of Ataxia Telangectasia Mutated protein (ATM) which is the proximal step for cell cycle check points activation (G2/M arrest). The nuclear apoptotic factor P84 is up regulated, which participates in the apoptotic response of the cells. DSB stimulate the phosphorylation of histone-2AX through the Mre11, RAD50, NBS1 complex and p-ATM with a feedback loop amplification. Phosphorylated histone-2AX ( $\boldsymbol{\gamma}-\mathrm{H} 2 \mathrm{AX})$ stimulated both the homologous recombination repair ( $\mathrm{HR}$, active in S and $\mathrm{G} 2$ phases only) and the nonhomologous end-joining repair (NHEJ, active in all cell cycle phases) of the DSB. Rad-51 is 
considered one of the mandatory proteins for HR to occur. DNA-PK is the major protein in the NHEJ repair pathway. Both proteins were up regulated in irradiated MSCs. P-ATM and pDNA-PK activate the cell cycle check point kinases (Chk1 and Chk2) resulting in cyclin/Cdkmediated G2/M cell cycle arrest by inhibiting the Cell division cycle phosphatase (Cdc25). PATM also stabilizes the tumor suppressor regulatory protein and transcription factor P53 which up-regulates the expression and enhances the stabilization of the inhibitory regulatory protein p21, which potently inhibits Cdks needed for the G1/S transition leading to inhibition of the entry into $S$ phase.

\subsection{MSCS APPLICATIONS IN RADIATION ONCOLOGY REGENERATIVE MEDICINE (RORM)}

Adding up all their beneficial characteristics, MSCs have been selected for many RORM studies (Table.3.5.1).

\subsubsection{Skin repair application after radiation exposure}

MSCs have been used in the repair of radiation-induced skin injuries where they were administered systemically and lead to decreased radiation-induced skin fibrosis through enhancing the secretion of IL-10 and increasing the infiltration of antiinflammatory regulatory CD163(+) macrophages, decreasing the secretion of IL-1 beta and the numbers of infiltrated pro-inflammatory CD80(+) macrophages[69]. It was suggested that the autologous grafting of MSCs is more efficient than the allogenic grafting in cutaneous radiation syndrome [83]. MSCs secrete growth factors and anti-inflammatory mediators that can be combined with other external growth factors, e.g. basic fibroblast growth factor (b-FGF) in order to enhance the 
healing in radiation-induced skin damage [84]. The enhancement of the migration of fibroblasts and collagen will protect the fibroblasts from the oxidative stress of UVB radiation [84].

\subsubsection{Intestinal repair application after radiation exposure}

MSCs have been applied for the repair of radiation-induced intestinal injury [87, 161]. When MSCs were given before irradiation, treated mice showed higher body weight, thicker intestinal submucosal and muscle layer, significant higher survival rates and stromal derived factor-1 (SDF-1) expression, and lower numbers of radiation-induced ulcers[158, 161]. Another study reported that MSCs therapy showed better maintenance of epithelial homeostasis, neovascularization, high antiinflammatory IL-10, increased expression of VEGF, b-FGF and EGF in irradiated intestine, and increased the homing of CD31-positive hematopoietic stem cells or hematopoietic progenitor cells to the irradiated intestine [70]. MSCs therapy showed decreased activation and proliferation of T-lymphocytes together with increased local corticosterone secretion at the intestinal mucosa that highlighted an immunosuppressive effect of MSCs mediated by glucocorticoid receptors [162]. It was found that MSCs reparative and paracrine effects in radiation-induced intestinal injury were enhanced by pretreating them with TNF-alpha, IL-1 beta, and nitric oxide [163]. 


\subsubsection{Lung tissue repair application after radiation exposure}

MSCs therapy was shown to reduce radiation-induced lung tissue injury.

Administration of MSCs resulted in decreased radiation-induced inflammatory response in terms of reduced pro-inflammatory mediators (IL-1 beta, IL-6, TNFalpha), increased anti-inflammatory mediators (IL-10), reduced expression of TGF- $\beta$, alpha-smooth muscle actin (Alpha-SMA) and type 1 collagen level, and control of the pro- and anti-apoptotic mediators (Bcl-2, Bax and caspase-3) protecting the lung tissue from apoptosis[68]. Moreover, MSCs therapy reduced bronchial epithelium senescence and lowered the risk of metastatic spread in lung tissue [67]. In addition, MSCs therapy decreased the mortality rate in mice with radiation-induced lung injury [164]. These cells showed a proven beneficial therapeutic effect in radiation pneumonitis as well [165].

\subsubsection{Hematopoietic system homeostasis radiation injury}

MSCs therapy has been shown to reduce the radiation-induced bone marrow apoptosis, and they enhance megakaryopoiesis, and platelets recovery [166]. Moreover, MSCs therapy resulted in improved recovery of the hematopoietic system through decreased apoptosis and radiation induced oxidative stress $[167,168]$.

\subsubsection{Radiation-induced cardiac injuries}

A case report of a patient suffering from late radiation cardiomyopathy and radiation exudative pericarditis after radiotherapy of Hodgkin lymphoma showed that systemically transplanted MSCs partially differentiated to cardiomyocytes [169]. 


\subsubsection{Radiation-induced salivary gland injury}

In irradiated mice, systemically transplanted MSCs resulted in improvement of the saliva flow rate, lower salivary gland damage and atrophic acini and higher mucin and amylase production[85].

\subsubsection{Radiation-induced oral mucositis}

Bone marrow-derived mesenchymal stromal cells (bmMSCs) therapy have been applied in fractionated radiation-induced oral mucositis where the administration of a systemic single dose of 6 million MSCs resulted in a significant decrease in ED50 (the RT dose that produces ulcer in $50 \%$ of irradiated mice) [141]. The first MSCs therapy for RIOM was done in 2014 by Schmidt et al. and concluded that transplantation of bone marrow (BM) or bmMSCs could modulate RIOM in fractionated RT, depending on the time of transplantation [48]. Nevertheless, in another study they also concluded that bmMSCs transplantation had no therapeutic benefits on RIOM in single dose RT when compared to the therapeutic gain by the mobilization of endogenous BM stem cells [72]. Further studies are needed in this field since the initial studies showed significant clinically relevant therapeutic effects.

\subsubsection{Liver tissue protection}

MSCs therapy reduced the radiation-induced liver injury by anti-oxidative, vascular protection, hepatocyte differentiation, and trophic mechanisms. The anti-oxidative mechanism was suggested by the decreased expression of Nrf2, superoxide dismutase (SOD) gene in MSCs-treated irradiated livers with decreased apoptotic 
cells. The increased expression of VEGF and Angiopoietin-1 (Ang-1) in the perivascular region, associated with an increased expression of VEGFr1, r2 suggested the vascular protection mechanism in the livers of MSCs-treated animals. After engrafting, MSCs showed expression of cytokeratin CK18 and CK19 and alpha-fetoprotein (AFP) genes which suggested hepatocyte differentiation. The increased secretion of nerve growth factor (NGF), hepatocyte growth factor (HGF), and anti-inflammatory molecules IL-10, IL1-RA suggested MSCs' trophic effects $[162,170]$. MSCs conditioned media improved the viability of liver sinusoidal endothelial cells (SECs) in vitro. Infusion of MSCs conditioned media significantly reduced the radiation-induced SECs apoptosis and improved the histopathological picture of irradiated livers. In addition, there was increased secretion of antiinflammatory cytokines and decreased secretion of pro-inflammatory cytokines [162, 171].

\subsubsection{Studies with gene-modified MSCs for RORM}

Genetically modified MSCs have been applied in RORM studies. HGF-expressing MSCs have improved the radiation-induced intestinal injury where they increased the expression of anti-inflammatory mediators and improved the histopathological picture of irradiated intestine [148]. A similar picture was noted with TGF-betaexpressing MSCs therapy in radiation-induced lung injury [150].

Although limited data are available for the clinical application of MSCs in radiationinduced normal tissue injury, promising therapeutic benefits have been shown in a small number of isolated clinical studies [71]. 
Isolated clinical case reports showed promising beneficial effects of MSCs therapy;

e.g. regenerating hematopoiesis and osteoradionecrosis, improved breathing parameters and lung immune function, improved intestinal mucosal inflammation, hemorrhages, fistulization, pain and diarrhea, and regenerated skin ulceration, in ionizing radiation-induced injury of bone, lung, intestine, and skin, respectively ([71, 89, 162, 172] Table.3.5.1 summarizes the recent preclinical and clinical studies conducted in RORM applying MSCs therapies.

Table.3.5.1 Mesenchymal stromal/stem cells (MSCs) preclinical and clinical studies in RORM [53, 55]

\begin{tabular}{|l|l|l|l|l|l|l|}
\hline $\begin{array}{l}\text { Organ/ } \\
\text { system }\end{array}$ & $\begin{array}{l}\text { RT } \\
\text { dose } \\
(\mathbf{G y})\end{array}$ & $\begin{array}{l}\text { Normal } \\
\text { Tissue } \\
\text { Endpoint }\end{array}$ & Paradigm & $\begin{array}{l}\text { Stem cell } \\
\text { type } \\
\text { therapy } \\
\text { (preclinical } \\
\text { studies) }\end{array}$ & $\begin{array}{l}\text { Stem cell } \\
\text { type } \\
\text { therapy } \\
\text { (clinical } \\
\text { trial) }\end{array}$ & $\begin{array}{l}\text { Follow } \\
\text { up time }\end{array}$ \\
\hline $\begin{array}{l}\text { Bone } \\
\text { marrow }\end{array}$ & 12 & $\begin{array}{l}\text { Bone marrow } \\
\text { aplasia }\end{array}$ & $\begin{array}{l}\text { Hematopoietic } \\
\text { stem } \\
\text { cell/progenitor } \\
\text { depletion and } \\
\text { stem cell } \\
\text { "niche" } \\
\text { destruction }\end{array}$ & $\begin{array}{l}\text { BM, hSC, } \\
\text { bmMSC }\end{array}$ & BM (81) & $\begin{array}{l}30 \\
\text { years }\end{array}$ \\
\hline Brain & $>57$ & $\begin{array}{l}\text { Brain radio- } \\
\text { necrosis, } \\
\text { cognitive } \\
\text { dysfunction }\end{array}$ & $\begin{array}{l}\text { Inflammation, } \\
\text { vascular } \\
\text { breakdown, } \\
\text { disruption of } \\
\text { BBB, CNS } \\
\text { progenitor } \\
\text { depletion, stem } \\
\text { cell "niche" } \\
\text { destruction, } \\
\text { hypoxia, } \\
\text { demyelination, } \\
\text { necrosis }\end{array}$ & $\begin{array}{l}\text { hESC, } \\
\text { hNSC }\end{array}$ & No & - \\
\hline $\begin{array}{l}\text { Salivary } \\
\text { glands }\end{array}>35$ & $\begin{array}{l}\text { Xerostomia, } \\
\text { salivary flow }\end{array}$ & $\begin{array}{l}\text { Stem } \\
\text { cell/progenitor } \\
\text { depletion }\end{array}$ & $\begin{array}{l}\text { BM, } \\
\text { bmMSC, } \\
\text { salivary }\end{array}$ & No & - \\
\hline
\end{tabular}




\begin{tabular}{|c|c|c|c|c|c|c|}
\hline & & & & $\begin{array}{l}\text { gland stem } \\
\text { cell }\end{array}$ & & \\
\hline Bone & $>60$ & $\begin{array}{l}\text { Bone growth } \\
\text { alteration, } \\
\text { bone } \\
\text { weakening, } \\
\text { and osteo- } \\
\text { radionecrosis }\end{array}$ & $\begin{array}{l}\text { Hypocellularity, } \\
\text { hypovasculariza } \\
\text { tion, hypoxia, } \\
\text { and fibro- } \\
\text { necrosis }\end{array}$ & $\begin{array}{l}\text { BM, } \\
\text { bmMSC }\end{array}$ & $\begin{array}{l}\text { BM } \\
\text { associate } \\
\text { d to } \\
\text { biomateria } \\
\text { I (Phase I) }\end{array}$ & $\begin{array}{l}\text { Few } \\
\text { months }\end{array}$ \\
\hline Skin & $>50$ & $\begin{array}{l}\text { Skin } \\
\text { radionecrosis } \\
\text {, pain }\end{array}$ & $\begin{array}{l}\text { Chronic } \\
\text { inflammation, } \\
\text { damage to the } \\
\text { microvasculatur } \\
\text { e, epidermis } \\
\text { stem cell/ } \\
\text { progenitor } \\
\text { depletion, } \\
\text { ischemia, } \\
\text { fibroblast death, } \\
\text { and fibro- } \\
\text { necrosis }\end{array}$ & $\begin{array}{l}\text { bmMSC, } \\
\text { aMSCs, } \\
\text { EPC }\end{array}$ & $\begin{array}{l}\text { bmMSC } \\
\text { (local } \\
\text { injection, } \\
2 \times 10^{6} / \mathrm{kg}, \\
\text { repetitive } \\
\text { injections, } \\
\text { curative } \\
\text { startegy) } \\
\text { (compatio- } \\
\text { nnal } \\
\text { treatment) } \\
\text { and } \\
\text { lipoaspira- } \\
\text { te } \\
\text { (Phasel) }\end{array}$ & $\begin{array}{l}8 \text { years } \\
\text { and } 13 \\
\text { months }\end{array}$ \\
\hline Liver & $>35$ & $\begin{array}{l}\text { Radiation- } \\
\text { induced liver } \\
\text { disease, } \\
\text { sinusoidal } \\
\text { obstructive } \\
\text { syndrome }\end{array}$ & $\begin{array}{l}\text { Vascular } \\
\text { (sinusoidal) } \\
\text { breakdown, } \\
\text { hepatocyte cell } \\
\text { death, and } \\
\text { inhibition of } \\
\text { hepatocellular } \\
\text { regeneration }\end{array}$ & Hepatocyte & $\begin{array}{l}\text { Hepatocy- } \\
\text { te } \\
\text { (intraspel- } \\
\text { nic } \\
\text { transplan- } \\
\text { tation, } \\
6 \times 10^{6} \\
\text { cells) } \\
\text { (Phase I) }\end{array}$ & - \\
\hline Heart & $\begin{array}{l}>30- \\
40\end{array}$ & $\begin{array}{l}\text { Atheroscler- } \\
\text { osis, cardiac } \\
\text { attack }\end{array}$ & $\begin{array}{l}\text { Inflammation, } \\
\text { damage to the } \\
\text { microvasculatur } \\
\text { e, ischemia, } \\
\text { myocardial cell } \\
\text { death, and fibro- } \\
\text { necrosis }\end{array}$ & - & No & - \\
\hline $\begin{array}{l}\text { Colon- } \\
\text { rectum }\end{array}$ & $>35$ & $\begin{array}{l}\text { Pelvic } \\
\text { radiation } \\
\text { disease, colo- } \\
\text { rectal } \\
\text { ulceration, } \\
\text { rectitis, }\end{array}$ & $\begin{array}{l}\text { Chronic } \\
\text { inflammation, } \\
\text { damage to the } \\
\text { microvasculatur } \\
\text { e, epithelial } \\
\text { stem } \\
\text { cell/progenitor }\end{array}$ & bmMSC & $\begin{array}{l}\text { bmMSC } \\
\text { (i.v. } \\
\text { injection, } \\
2 \times 10^{6} / \mathrm{kg} \text {, } \\
\text { repetitive } \\
\text { injections) } \\
\text { (compass- }\end{array}$ & 4 years \\
\hline
\end{tabular}




\begin{tabular}{|l|l|l|l|l|l|}
\hline & $\begin{array}{l}\text { cystitis, and } \\
\text { fistulae }\end{array}$ & $\begin{array}{l}\text { depletion, } \\
\text { ischemia, } \\
\text { myofibroblast } \\
\text { death, and fibro- } \\
\text { necrosis }\end{array}$ & $\begin{array}{l}\text { ional } \\
\text { treatment })\end{array}$ & \\
\hline
\end{tabular}

Table.3.5.1: MSCs preclinical and clinical studies conducted in RORM [71, 89]

aMSCs = adipose-derived mesenchymal stromal cell, bmMSC = bone marrow MSCs; BBB = blood brain barrier; $\mathrm{BM}=$ bone marrow; $\mathrm{CNS}=$ central nervous system; $\mathrm{EPC}=$ endothelial progenitor cells; GFAP = glial fibrillary acidic protein; hESC = human embryonic stem cell; hSC = human stem cells; hNSC = human neural stem cell, $\mathrm{RT}=$ radiation .

\subsection{ADIPOSE TISSUE-DERIVED MSCS (AMSCS)}

Adipose tissue-derived mesenchymal stem/stromal cells (aMSCs) are multipotent progenitor cells located in the stromal vascular fraction (SVF) of adipose tissue [74]. They are characterized by expressing cell surface antigens Sca1, CD106, CD105, CD73, CD29, and CD44, and lacking the expression of hematopoietic stem cells (HSCs) surface antigens (e.g. CD11b and CD45) [74-76]. In addition to their multilineage differentiation potential, they have anti-inflammatory/immune-modulatory and paracrine effects. In addition, MSCs home to the site of tissue injury that is caused irradiation and inflammation [74, 77, 78]. aMSCs are promising for cellular therapies due to their prominent anti-inflammatory effects, enhancing IL-10 secretion, ease of isolation, high cell count after expansion, as well as their source abundance [73]. Table.3.6.1 lists 22 clinical trials using aMSCs therapy for various disorders, with no trial yet found for the application in RORM following a search on the clinical trial website of the NIH by Nov. 2015. 


\begin{tabular}{|c|c|c|c|c|}
\hline $\begin{array}{ll}\mathrm{NCT} \\
\#\end{array}$ & Title & Conditions & Interventions & $\begin{array}{l}\text { Last } \\
\text { Verified }\end{array}$ \\
\hline $\begin{array}{l}\text { NCT } \\
0260 \\
3744\end{array}$ & $\begin{array}{l}\text { Autologous Adipose Derived } \\
\text { Mesenchymal Stromal Cells } \\
\text { (aMSCs) Transplantation in } \\
\text { Women With Premature } \\
\text { Ovarian Failure (POF) }\end{array}$ & $\begin{array}{l}\text { Premature } \\
\text { Ovarian } \\
\text { Failure }\end{array}$ & $\begin{array}{l}\text { Biological: } \\
\text { Intraovarian injection } \\
\text { of aMSCs }\end{array}$ & Nov-15 \\
\hline $\begin{array}{l}\text { NCT } \\
0144 \\
9032\end{array}$ & $\begin{array}{l}\text { MSCs Therapy in Patients } \\
\text { With Chronic Myocardial } \\
\text { Ischemia (MyStromalCell } \\
\text { Trial) }\end{array}$ & $\begin{array}{l}\text { Chronic } \\
\text { Ischemic } \\
\text { Heart } \\
\text { Disease }\end{array}$ & $\begin{array}{l}\text { Biological: } \\
\text { MSCs|Biological: } \\
\text { Saline }\end{array}$ & Jun-14 \\
\hline $\begin{array}{l}\text { NCT } \\
0158 \\
5857\end{array}$ & ADIPOA - Clinical Study & Osteoarthritis & $\begin{array}{l}\text { Biological: } \\
\text { Autologous aMSCs } \\
\text { administrated for } \\
\text { intra-articular } \\
\text { use|Biological: } \\
\text { Autologous aMSCs } \\
\text { administrated for } \\
\text { intra-articular use }\end{array}$ & Dec-14 \\
\hline $\begin{array}{l}\text { NCT } \\
0238 \\
2874\end{array}$ & $\begin{array}{l}\text { Allogenic aMSCs } \\
\text { Transplantation in Idiopathic } \\
\text { Nephrotic Syndrome (Focal } \\
\text { Segmental } \\
\text { Glomerulosclerosis) }\end{array}$ & $\begin{array}{l}\text { Focal } \\
\text { Segmental } \\
\text { Glomeruloscl } \\
\text { erosis }\end{array}$ & $\begin{array}{l}\text { Biological: } \\
\text { Intravenous injection }\end{array}$ & Mar-15 \\
\hline $\begin{array}{l}\text { NCT } \\
0224 \\
0823\end{array}$ & $\begin{array}{l}\text { Can Fat Derived Stem Cells } \\
\text { (SVF) be Used in the } \\
\text { Treatment of Erectile } \\
\text { Dysfunction After } \\
\text { Prostatectomy }\end{array}$ & $\begin{array}{l}\text { Delayed Graft } \\
\text { Function }\end{array}$ & Other: aMSCs & Oct-15 \\
\hline $\begin{array}{l}\text { NCT } \\
0232 \\
6935\end{array}$ & $\begin{array}{l}\text { Multi-Center Study Safety of } \\
\text { aMSCs for the Treatment of } \\
\text { Multiple Sclerosis }\end{array}$ & $\begin{array}{l}\text { Multiple } \\
\text { Sclerosis }\end{array}$ & $\begin{array}{l}\text { Biological: } \\
\text { Autologous aMSCs }\end{array}$ & Jan-15 \\
\hline $\begin{array}{l}\text { NCT } \\
0091 \\
3289\end{array}$ & $\begin{array}{l}\text { Liver Regeneration Therapy } \\
\text { Using Autologous aMSCs }\end{array}$ & $\begin{array}{l}\text { Liver } \\
\text { Cirrhosis }\end{array}$ & Biological: aMSCs & Oct-12 \\
\hline
\end{tabular}




\begin{tabular}{|c|c|c|c|c|}
\hline $\begin{array}{l}\text { NCT } \\
0106 \\
2750\end{array}$ & $\begin{array}{l}\text { Liver Regeneration Therapy } \\
\text { by Intrahepatic Arterial } \\
\text { Administration of Autologous } \\
\text { aMSCs }\end{array}$ & $\begin{array}{l}\text { Liver } \\
\text { Cirrhosis }\end{array}$ & $\begin{array}{l}\text { Biological: aMSCs } \\
\text { dosage }\end{array}$ & Sep-15 \\
\hline $\begin{array}{l}\text { NCT } \\
0233 \\
8271\end{array}$ & $\begin{array}{l}\text { Autologous aMSCs Therapy } \\
\text { for Intervertebral Disc } \\
\text { Degeneration }\end{array}$ & $\begin{array}{l}\text { Low Back } \\
\text { Pain }\end{array}$ & $\begin{array}{l}\text { Other: autologous } \\
\text { aMSCs }\end{array}$ & Jan-15 \\
\hline $\begin{array}{l}\text { NCT } \\
0170 \\
9279\end{array}$ & $\begin{array}{l}\text { Clinical Trial of Autologous } \\
\text { aMSCs Therapy for Ischemic } \\
\text { Heart Failure }\end{array}$ & $\begin{array}{l}\text { Ischemic } \\
\text { Heart Failure }\end{array}$ & $\begin{array}{l}\text { Biological: aMSCs } \\
\text { dosage }\end{array}$ & Oct-12 \\
\hline $\begin{array}{l}\text { NCT } \\
0173 \\
9504\end{array}$ & $\begin{array}{l}\text { Autologous aMSCs Delivered } \\
\text { Intra-articularly in Patients } \\
\text { With Osteoarthritis. }\end{array}$ & Osteoarthritis & $\begin{array}{l}\text { Procedure: } \\
\text { Autologous aMSCs } \\
\text { harvesting through } \\
\text { Liposuction for Intra- } \\
\text { articular Injection }\end{array}$ & Oct-15 \\
\hline $\begin{array}{l}\text { NCT } \\
0214 \\
5897\end{array}$ & $\begin{array}{l}\text { To Evaluate the Safety and } \\
\text { Efficacy of IM and IV } \\
\text { Administration of Autologous } \\
\text { aMSCs for Treatment of CLI }\end{array}$ & $\begin{array}{l}\text { Critical Limb } \\
\text { Ischemia } \\
\text { (CLI) }\end{array}$ & $\begin{array}{l}\text { Biological: } \\
\text { Autologous Stromal } \\
\text { Vascular Fraction } \\
\text { (SVF)|Biological: } \\
\text { Autologous aMSCs| } \\
\text { Other: Control }\end{array}$ & May-14 \\
\hline
\end{tabular}




\begin{tabular}{|c|c|c|c|c|}
\hline $\begin{array}{l}\text { NCT } \\
0184 \\
0540\end{array}$ & $\begin{array}{l}\text { MSC for Occlusive Disease of } \\
\text { the Kidney }\end{array}$ & $\begin{array}{l}\text { Atherosclerot- } \\
\text { ic Renal } \\
\text { Artery } \\
\text { Stenosis| } \\
\text { Ischemic } \\
\text { Nephropathy| } \\
\text { Renovascular } \\
\text { Hypertension }\end{array}$ & $\begin{array}{l}\text { Drug: Arterial } \\
\text { infusion of } \\
\text { autologous } \\
\text { mesenchymal stem } \\
\text { cells }\end{array}$ & Oct-15 \\
\hline $\begin{array}{l}\text { NCT } \\
0213 \\
5380\end{array}$ & $\begin{array}{l}\text { Evaluate Safety and Efficacy } \\
\text { of Intravenous Autologous } \\
\text { aMSC for Treatment of } \\
\text { Idiopathic Pulmonary Fibrosis }\end{array}$ & $\begin{array}{l}\text { Idiopathic } \\
\text { Pulmonary } \\
\text { Fibrosis }\end{array}$ & $\begin{array}{l}\text { Biological: } \\
\text { Autologous Stromal } \\
\text { Vascular Fraction } \\
\text { (SVF)|Biological: } \\
\text { Autologous aMSCs } \\
\text { |Other: Control }\end{array}$ & May-14 \\
\hline $\begin{array}{l}\text { NCT } \\
0154 \\
8092\end{array}$ & $\begin{array}{l}\text { Stromal Vascular Fraction } \\
\text { (SVF) for Treatment of Recto- } \\
\text { vaginal Fistula }\end{array}$ & $\begin{array}{l}\text { Recto-vaginal } \\
\text { Fistula }\end{array}$ & $\begin{array}{l}\text { Drug: aMSCs without } \\
\text { expanded }\end{array}$ & Mar-12 \\
\hline $\begin{array}{l}\text { NCT } \\
0177 \\
1913\end{array}$ & $\begin{array}{l}\text { Immunophenotyping of Fresh } \\
\text { Stromal Vascular Fraction } \\
\text { From aMSCs Enriched Fat } \\
\text { Grafts }\end{array}$ & $\begin{array}{l}\text { Breast } \\
\text { Reconstructio } \\
\mathrm{n} \mid \text { Contour } \\
\text { Irregularities| } \\
\text { Volume } \\
\text { Insufficiency }\end{array}$ & $\begin{array}{l}\text { Genetic: centrifuged } \\
\text { fat graft| Genetic: } \\
\text { aMSCs enriched fat } \\
\text { graft }\end{array}$ & Jul-15 \\
\hline
\end{tabular}




\begin{tabular}{|c|c|c|c|c|}
\hline $\begin{array}{l}\text { NCT } \\
0184 \\
9159\end{array}$ & $\begin{array}{l}\text { Clinical Study of the Efficacy } \\
\text { and Safety of the Application } \\
\text { of Allogeneic Mesenchymal } \\
\text { (Stromal) Cells of Bone } \\
\text { Marrow, Cultured Under the } \\
\text { Hypoxia in the Treatment of } \\
\text { Patients With Severe } \\
\text { Pulmonary Emphysema }\end{array}$ & $\begin{array}{l}\text { Pulmonary } \\
\text { Emphysema }\end{array}$ & $\begin{array}{l}\text { Biological: } \\
\text { Mesenchymal stem } \\
\text { cells|Other: } \\
\text { Reference therapy: } \\
400 \mathrm{~mL} \text { of } 0.9 \% \mathrm{NaCl} \\
\text { solution }\end{array}$ & Oct-15 \\
\hline $\begin{array}{l}\text { NCT } \\
0153 \\
2076\end{array}$ & $\begin{array}{l}\text { Effectiveness of aMSCs as } \\
\text { Osteogenic Component in } \\
\text { Composite Grafts }\end{array}$ & $\begin{array}{l}\text { Osteoporotic } \\
\text { Fractures }\end{array}$ & $\begin{array}{l}\text { Procedure: } \\
\text { Cellularized } \\
\text { composite graft } \\
\text { augmentation|Proced } \\
\text { ure: Acellular } \\
\text { composite graft } \\
\text { augmentation }\end{array}$ & Sep-14 \\
\hline $\begin{array}{l}\text { NCT } \\
0238 \\
7723\end{array}$ & $\begin{array}{l}\text { CSCC_ASC Therapy in } \\
\text { Patients With Severe Heart } \\
\text { Failure }\end{array}$ & $\begin{array}{l}\text { Clinical } \\
\text { Patient } \\
\text { Safety of } \\
\text { Allogeneic } \\
\text { Stem Cell } \\
\text { Therapy }\end{array}$ & $\begin{array}{l}\text { Biological: Allogeneic } \\
\text { aMSCs } \\
\text { (CSCC_ASC) }\end{array}$ & Mar-15 \\
\hline $\begin{array}{l}\text { NCT } \\
0173 \\
0547\end{array}$ & $\begin{array}{l}\text { Mesenchymal Stem Cells for } \\
\text { Multiple Sclerosis }\end{array}$ & $\begin{array}{l}\text { Multiple } \\
\text { Sclerosis }\end{array}$ & $\begin{array}{l}\text { Biological: } \\
\text { Autologous } \\
\text { mesenchymal stem } \\
\text { cells }\end{array}$ & Jan-15 \\
\hline $\begin{array}{l}\text { NCT } \\
0249 \\
2490\end{array}$ & $\begin{array}{l}\text { Effect of SVF-derived MSC in } \\
\text { DCD Renal Transplantation }\end{array}$ & Uremia & $\begin{array}{l}\text { Other: SVF-derived } \\
\text { MSC } \\
\text { transplantations|Drug } \\
\text { : Basiliximab }\end{array}$ & Nov-14 \\
\hline $\begin{array}{l}\text { NCT } \\
0249 \\
2308\end{array}$ & $\begin{array}{l}\text { Induction With SVF Derived } \\
\text { MSC in Living-related Kidney } \\
\text { Transplantation }\end{array}$ & $\begin{array}{l}\text { Living-relative } \\
\text { Kidney } \\
\text { Transplantati } \\
\text { on }\end{array}$ & $\begin{array}{l}\text { Procedure: SVF- } \\
\text { MSC induction|Drug: } \\
\text { Basiliximab induction }\end{array}$ & Jul-15 \\
\hline
\end{tabular}


Table.3.6.1: Adipose Mesenchymal stromal cells (aMSCs) clinical trials

(www.ClinicalTrials.gov) by the National Institute of Health conducted in RORM

\subsection{MSCS MECHANISM OF ACTION IN RORM}

There are proposed mechanisms of action of MSCs radio-protective properties in radiation-induced normal tissue injury repair. Homing and paracrine effects with antiinflammatory/immunomodulatory mechanisms are supported by in-vitro data from radiation-induced intestinal injury studies and similar ones [77]. MSCs therapy in radiation-induced intestinal injury showed the homing of systematically administered MSCs in measurable numbers at the intestinal injury site $[87,158,163]$. There were

increased levels of IL-10, VEGF, b-FGF, and EGF. Histopathological studies showed improved intestinal epithelial homeostasis that might be owing to MSCs

overexpressing stromal cell-derived factor receptor CXCR-4 [71]. All these data support the homing and the paracrine mechanism of action rather that the regenerative and multipotent differentiation mechanism of action [71].

These findings suggest that the paracrine and the anti-inflammatory effect of MSCs is the expected radio-protective mechanism of action of MSCs in RORM rather than the differentiation to a specific cell type [71].

\subsection{CHALLENGES FACING MSCS THERAPY}

The fear of MSCs-mediated radioprotection of tumor tissues has been a raised concern after the availability of in-vitro data suggesting that breast cancer cells grow and proliferate more with MSCs-therapy owing to high insulin-like factor production [53]. Also, MSCs have some agiogenic properties evident by increased secretion of 
(platelets derived growth factor) PDGF, VEGF and TGF- $\beta$ at the tumor perivascular area and parenchyma in low dose irradiated mice owing to MSCs infiltration at the tumor site [53]. MSCs angiogenic properties might counteract the anti-angiogenic cancer therapies, a question that needs to be answered with solid in-vitro and in-vivo studies $[71,104]$.

Another challenge appeared in MSCs therapies. MSCs have been found to have heterogeneous radiation resistant populations, both in human and mouse MSCs [53]. A finding that might interfere with the overall radio-protective and tissue regenerative properties of MSCs. Nevertheless, studies might find molecular biomarkers for isolating homogenous populations of MSCs with uniform high RT resistance profile [71, 104].

A further challenge that has been found to be more frequent in mouse MSCs than in human MSCs, is MSCs in-vitro transformation (the tumorigenic potential of MSCs) [53]. Such challenge carries a significant worry among MSCs therapies, since MSCs are radio-resistant cells, their transformation may signify the generation of a severe form of radio-resistant tumor that is extremely hard to control. Tight and fine validation of MSCs before each single dose therapy is recommended for preventing the use of any potentially transformed cells $[71,99,104]$.

\subsection{CONCLUSION}

MSCs have been widely used in preclinical studies of radiation oncology regenerative medicine. MSCs have been shown to be reliable candidates in

radiation oncology regenerative medicine translational and clinical research. The 
strong potential of MSCs therapy yin RIOM is supported by their relative radiation resistance and robust DNA repair mechanisms, multi-lineage differentiation potential, and anti-inflammatory/immunomodulatory properties. Nevertheless, few but considerable challenges in MSCs therapies are requiring more research in order to develop solid solutions. However, the overall data collected from preclinical and clinical studies promise with MSCs therapy choices competing with traditional therapies. Adipose-tissue derived mesenchymal stromal/stem cells are reliable candidates for radiation oncology regenerative medicine applications owing to the advantages they possess, e.g. source abundance, enhanced anti-inflammatory effects, robust IL-10 secretion, easy isolation, high expansion. 
This page is intentionally left blank 
The next chapter represents our $1^{\text {st }}$ manuscript ${ }^{\star}$ showing our study to explore the radio-biological response of adipose tissue-derived mesenchymal stromal cells (aMSCs) for the following objectives:

1- Isolation, validation and in-vitro characterization of aMSCs.

2- Evaluation of aMSCs radiation sensitivity/resistance.

*Published in Cytotherapy Journal (Cytotherapy, 2016; 18: 384-401) [159]

[Appendix] 


\section{Chapter 4 ADIPOSE MESENCHYMAL STROMAL CELLS RESPONSE TO IONIZING RADIATION}

\section{Adipose Mesenchymal Stromal Cells Radiosensitivity}

Osama Muhammad Maria, MD, MSc ${ }^{1,2,3}$, Slawomir Kumala, $\mathrm{PhD}^{3,5,6}$, Mitra Heravi, $\mathrm{PhD}^{3,5,7}$, Alasdair Syme, $\mathrm{PhD}^{3,4,6}$, Nicoletta Eliopoulos, $\mathrm{PhD}^{2,5}$ and Thierry Muanza, $\mathrm{MD}, \mathrm{MSc}^{1,3,5,6}$

1 Experimental Medicine Department, Faculty of Medicine, McGill University, Montreal, Quebec, Canada

2 Surgery Department, Faculty of Medicine, McGill University, Montreal, Quebec, Canada

3 Radiation Oncology Department, Jewish General Hospital, McGill University, Montreal, Quebec, Canada

4 Medical Physics Unit, McGill University, Montreal, Quebec, Canada

5 Lady Davis Institute for Medical Research, Jewish General Hospital, McGill University, Montreal, Quebec, Canada

6 Oncology Department, McGill University, Montreal, Quebec, Canada

7 Genetics Department, McGill University, Montreal, Quebec, Canada

\section{AUTHOR CONTRIBUTIONS}

- Osama Maria: Conception and design, collection and/or assembly of data, data analysis and interpretation, manuscript writing, final approval of manuscript. 
- Slawomir Kumala: Conception and design

- Mitra Heravi: Conception and design

- Alasdair Syme: Conception and design

- Nicoletta Eliopoulos: Conception and design, provision of study material, data analysis and interpretation, final approval of manuscript.

- Thierry Muanza: Conception and design, financial support, provision of study material, data analysis and interpretation, final approval of manuscript.

\section{THE CORRESPONDING AUTHOR}

\section{Dr. Thierry Muanza, MD MSc FRCPC}

Radiation Oncology Translational Research Lab,

Department of Radiation Oncology,

Jewish General Hospital and Lady Davis Institute Research Centre, McGill University,

3755 Côte-St.-Catherine Road, Suite G002,

Montréal, Québec,

Canada, H3T 1E2

Tel: +1 (514)-340-8288, Fax: + 1 (514)-340-7548,

Email:tmuanza@yahoo.com

Disclaimer: None 


\subsection{ABSTRACT}

Background: This study evaluates the biological response of adipose tissue-derived mesenchymal stromal cells (aMSCs) to ionizing radiation (IR).

Methods: Irradiated BALB/c mice aMSCs were characterized for functionality and phenotype. The clonogenic capacity of irradiated aMSCs was assessed and compared to those of metastatic breast cancer cell line (4T1) and normal mouse fibroblasts (NIH3T3-wt). We investigated the IR-induced DNA damage response, apoptosis, changes in cell cycle (CC) dynamics and protein and gene expression. Results: Irradiated and non-irradiated aMSCs were able to differentiate into adipocytes, chondrocytes and osteocytes with no significant difference. Irradiated aMSCs maintained the expression of mesenchymal stromal/stem cells (MSCs) surface antigens and, as expected, were negative for hematopoietic stem cells (HSCs) surface antigens when tested up to 7 days after IR for all irradiation doses with no significant difference. Clonogenically, irradiated aMSCs had higher relative survival fraction (rSF) and plating efficiency (PE) than 4T1 and NIH3T3-wt. Irradiated aMSCs expressed higher $\gamma-\mathrm{H} 2 \mathrm{AX}$ and significantly showed faster and more timeefficient IR-induced DNA damage response evident by up regulated DNA-PKcs and RAD51. 2 hours after IR, most of aMSCs DNA damage/repair-related genes showed up regulation that disappeared within 6 hours after IR. Irradiated aMSCs showed a significant rise and an earlier peak of p-ATM-dependent and -independent (p84/5E10-mediated) G2/M CC arrest compared to 4T1 and NIH3T3-wt.

Discussion and conclusion: After IR exposure, aMSCs showed a robust and timeefficient radiation-induced DNA damage repair response, stable phenotypical 
characteristics and multi-lineage differentiation potential recommending them as reliable candidates for cell therapy in radiation oncology regenerative medicine. 
Keywords: adipose Mesenchymal Stromal Cells, Cell Cycle, DNA Damage Repair, G2/M Arrest, Gene Expression, lonizing Radiation, Radiation Resistance 


\subsection{INTRODUCTION}

Adipose tissue-derived mesenchymal stem/stromal cells (aMSCs) are multipotent progenitor cells located in the stromal vascular fraction (SVF) of adipose tissue [74]. They are characterized by expressing MSCs-expected surface antigens; Sca1, CD106, CD105, CD73, CD29, and CD44, and lacking the expression of hematopoietic stem cells (HSCs) surface antigens (e.g. CD11b and CD45) [74-76]. In addition to their multi-lineage differentiation potential, they have anti-inflammatory/immunemodulatory and paracrine effects. They also have the ability to home to the site of tissue injury after irradiation and inflammation $[74,77,78]$. aMSCs are promising for cellular therapies due to their prominent anti-inflammatory effects, enhancing IL-10 secretion, ease of isolation, high cell count after expansion as well as their source abundance [73].

In radiation oncology regenerative medicine (RORM) applications, aMSCs therapy is a rapidly growing domain of cell therapy for radiation-induced normal tissue injury. aMSCs have been investigated in many studies for cutaneous radiation syndrome [79-83] and photo-aging [84] where they have shown significant tissue repair. In addition, aMSCs systemic cell therapy has shown significant restoration and improvement of acute salivary gland [85] and intestine injuries [70, 86-88] induced by ionizing radiation (IR). Furthermore, aMSCs showed a promising potential of being a successful cell therapy option in chronic injuries induced by radiotherapy as well $[80,89]$.

These studies highlighted the need for characterizing the radiation resistance/sensitivity of aMSCs for their application in RORM cell therapies; since 
that will allow us to determine the future behavior/outcome of aMSCs therapies before or during fractionated radiotherapy $[90,91]$. In that perspective, it was found that, some cell surface antigens present on MSCs; Sca-1, CD29, and CD44 have been linked with cellular radio-resistance [92, 93]. In addition, the surface antigen CD105 presence is important for normal cellular DNA repair [94]. Different mechanisms have been reported explaining such radio-resistance such as, cell cycle (CC) arrest (G2/M arrest) and activation of double stranded DNA (dsDNA) damage repair; namely the homologous recombination repair (HRR) and non-homologous end joining repair (NHEJR) [95-99]. These mechanisms were also evidenced to be responsible for the IR resistance of cancer stem cells (CSC), also known as cancer initiating cells, which have been linked to cancer disease recurrence and aggression [100-103].

4T1 cells are a highly metastatic triple-negative mouse breast cancer cell line expressing mesenchymal antigens. It has been documented that, these cells have a considerable subpopulation of CSC that confer proven IR resistance $[92,101,107$ 111]. These two characteristics make these cells a reliable candidate for comparing its IR biological response to that of aMSCs.

In this study, we aimed to evaluate the biological response of aMSCs to ionizing radiation exposure in comparison to these $4 \mathrm{~T} 1$ cells, as a mesenchymal-like cancer cell model that has considerable ionizing radiation-resistant CSC subpopulation, and to mouse fibroblasts (NIH3T3-wt) as a normal cell model. 


\subsection{MATERIALS AND METHODS}

\subsubsection{Isolation of mouse adipose tissue-derived MSCs (aMSCs)}

aMSCs were isolated according to the published methodology [173-176] with minimal modifications. In short, white adipose tissue of BALB/c mice from Charles River Laboratories ${ }^{\circledR}$ (Montreal, QC, Canada) was sterilely collected, washed, minced and digested in $1 \mathrm{X}$ sterile PBS (Invitrogen ${ }^{\circledR}$ ), $2 \%$ heat-inactivated FBS (iFBS, Wisent $^{\circledR}$, St-Bruno, QC, Canada) \& $2 \mathrm{mg} / \mathrm{mL}$ collagenase type II (Invitrogen ${ }^{\circledR}$, Burlington, ON, Canada) at $37^{\circ} \mathrm{C}$ for 15 min. After filtration, cell suspension was spun down and cell pellet (Stromal Vascular Fraction, SVF) was re-suspended in $0.83 \%$ Ammonium Chloride $\left(\mathrm{NH}_{4} \mathrm{Cl}\right)$ for erythrocytes lysis. SVF Cells were plated in a $25 \mathrm{~mL}$ flask containing 1X Dulbecco's Modified Eagle's Media (DMEM, Invitrogen $\left.{ }^{\circledR}\right), 10 \%$ iFBS $\left(\right.$ Wisent $\left.{ }^{\circledR}\right), 1 \%$ penicillin/streptomycin from Gibco ${ }^{\circledR}$ (distributed by Invitrogen Canada, Inc., Burlington, ON, Canada), at $37^{\circ} \mathrm{C} \& 5 \% \mathrm{CO}_{2}$ after counting with Trypan blue to verify the cell viability. Medium was freshly supplemented with 2-20 ng/mL mouse Fibroblast Growth Factor-2 (FGF-2, SigmaAldrich $^{\circledR}$ ) and $5 \mathrm{U} / \mathrm{mL}$ Sodium purified Heparin (Sigma-Aldrich ${ }^{\circledR}$ ).

\subsubsection{Determination of cell survival}

Cell sensitivity to IR was measured by clonogenic assay (CA) we previously published [177]. Cells were plated in 6 well plastic plates at plating densities of 100 , $200,400,600$ and 800 cells/well for IR doses of 0, 2, 4, 6 and 8 Gy, respectively, using $18 \mathrm{MV}$ photons of a Varian ${ }^{\circledR} 21 \mathrm{EX}$ linear accelerator (Palo Alto, CA, USA). NIH3T3-wt cells were plated in 6 well plates with a feeding layer of $1 \times 10^{4}$ cells $/$ well of NIH3T3-wt cells pre-irradiated with 50 Gy to enhance their Platting Efficiency 
(PE). CAs were irradiated 24 hours after plating. Colonies were counted 10 days after culture at $37^{\circ} \mathrm{C}$ and $5 \% \mathrm{CO}_{2}$ incubator.

\subsection{3 aMSCs functional differentiation assays}

Mouse Mesenchymal Stem Cell Functional Differentiation Kit from R\& D Systems ${ }^{\circledR}$, Inc. (Minneapolis, MN, USA, Cat. \# SC010) was used for differentiation of irradiated and non-irradiated aMSCs to adipocytes, osteocytes and chondrocytes according to the manufacture's protocol. IR doses were 2, 4, 6, and 8 Gy. For adipogenesis, cells were seeded until $80 \%$ confluence. Then, media was replaced by $0.5 \mathrm{~mL}$ adipogenic differentiation media and kept in culture for 10-14 days. For osteogenesis, cells were seeded until $70 \%$ confluence. Then, media was replaced by $0.5 \mathrm{~mL}$ osteogenesis differentiation medium and kept in culture for 14-21 days. Both newly formed adipocytes and osteocytes were fixed with paraformaldehyde for immunohistochemistry (IHC) staining. For chondrogenesis, a cell pellet of $15 \times 10^{3}$ cells was kept in chondrogenic differentiation medium for 17-21 days. Then, cell pellet was fixed with zinc formalin solution overnight, paraffin-embedded and sectioned. Antigen retrieval was done using the Universal Antigen Retrieval Reagent from R\&D Systems ${ }^{\circledR}$, Inc. (Cat.\# CTS015) before IHC.

\subsubsection{Immunohistochemistry (IHC) staining}

Cells and sections were washed, then blocked with $0.3 \%$ Triton X-100, 1\% BSA and $10 \%$ normal donkey serum in PBS for 45 min at room temperature. Cells were incubated at $4^{\circ} \mathrm{C}$ overnight with goat anti-mouse fatty acid binding protein-4 (FABP4) primary antibody for adipocytes, goat anti-mouse osteopontin antibody for osteocytes, and sheep anti-mouse collagen-II antibody for chondrocytes. Antibodies 
were purchased from R\&D Systems ${ }^{\circledR}$, Inc. After 3 washes, cells were incubated in the dark with diluted (1:200) NL557-conjugated donkey anti-goat secondary antibody (R\&D Systems ${ }^{\circledR}$, Inc., Cat. \# NL001) for 60 min at room temperature. Cells were washed 3 times and visualized with a fluorescent microscope.

\subsubsection{Flow cytometry (FC)}

Mouse Multipotent Stromal Cell Marker Antibody Panel from R\&D System ${ }^{\circledR}$, Inc. (Cat.\# SC018) was used for validation of aMSCs according to the manufacturer's protocol. Briefly, irradiated and non-irradiated aMSCs were harvested at different time points. Then, harvested aMSCs were suspended in FC staining buffer at a concentration of $1 \times 10^{6}$ cells $/ \mathrm{ml}$. For each MSCs marker antibody, $90 \mu \mathrm{L}$ of cell suspension were mixed with $10 \mu \mathrm{L}$ of each antibody of $100 \mu \mathrm{g} / \mathrm{mL}$ concentration and incubated for $30 \mathrm{~min}$ at $4^{\circ} \mathrm{C}$. After incubation and washing, cells were suspended in $200 \mu \mathrm{L}$ of the buffer including $10 \mu \mathrm{L}$ of goat F(ab')2 anti-rat IgG-FITC (Cat.\# F0104B, from R\&D System ${ }^{\circledR}$, Inc.) for 30 min at $4^{\circ} \mathrm{C}$ in dark. Cells were washed and suspended in $200 \mu \mathrm{L}$ buffer for FC analysis using BD FACS-Calibur ${ }^{\circledR}$ machine (BD Immunocytometry systems, San Jose, CA). IR doses were 2, 4, 6, and 8 Gy.

\subsubsection{Cell irradiation}

Cells were irradiated using a clinical linear accelerator $\left(\right.$ Clinac $^{\circledR} 21 \mathrm{EX}$, Varian Medical Systems, Palo Alto, CA USA) using our previous setup [178] with minimal variations. Briefly, cells cultured in 6 well plates were placed on top of a stack of solid water of $10 \mathrm{~cm}$ height (Gammex Inc, Middleton, WI, USA) and surrounded by a plastic holding frame. An additional $3 \mathrm{~cm}$ of solid water was placed on top of the plates and the frame to provide the build-up material within a field size of $25 \times 25 \mathrm{~cm}$ 
and with a machine output of $117.5 \mathrm{cGy} / 100 \mathrm{MUs}$. Cells cultured in $175 \mathrm{ml}$ flasks were placed on top of a stack of solid water of $5 \mathrm{~cm}$ height, then a $4 \mathrm{~cm}$ solid water was placed on top of the flasks within a field size of $35 \times 35 \mathrm{~cm}$ and with a machine output of $112.9 \mathrm{cGy} / 100 \mathrm{MUs}$. Rice bags were used in order to eliminate air gaps within the flasks setup. All cells were irradiated using 18 MV photons, SSD of 100 $\mathrm{cm}, \mathrm{PDD}$ of $89 \%$, and RDF of 1.096 . The dose delivered to the cells in both setups was calculated based on the ion chamber measurements and the clinical dosimetry data for a dose rate of $600 \mathrm{cGy} / \mathrm{min}$.

\subsubsection{Western blot}

After cell lysis and protein isolation, electrophoresis was performed with Invitrogen ${ }^{\circledR}$ X-Cell SureLock ${ }^{\circledR}$ Mini-Cell (Cat.\# EI0002) according to the manufacturer's protocol. For blotting, we used Thermo ${ }^{\circledR}$ Scientific Owl Panther semidry electro-blotter (20 x $20 \mathrm{~cm}$, part No. HEP-1) according to our pervious methodology [179]. After washing and blocking, membranes were incubated overnight with the following primary antibodies in $5 \% \mathrm{w} / \mathrm{v}$ BSA at $4^{\circ} \mathrm{C}: 1 / 1000$ of mouse anti-ATM (phospho S1981) antibody [10H11.E12] (Cat.\# ab36810), 1/1000 of rabbit anti-DNA-PKcs antibody (Cat.\# ab70250), 1/500 of mouse anti-Rad51 antibody [51RAD01] (Cat.\# ab1837), and 1/10000 of mouse anti-GAPDH antibody [Cat.\# GT239], and 1/1000 of antimouse p84/5E10 antibody [5E10] (Cat.\#GTX70220). After washing, we incubated membranes with corresponding secondary antibodies at room temperature for 30 min: 1/2000 of horseradish peroxidase (HRP)-linked anti-mouse IgG (Cat.\# 7076) and 1/1500 of goat anti-rabbit HRP-linked IgG (Cat.\# 7074) (except for GAPDH, we used 1/40000) from Cell Signalling ${ }^{\circledR}$. After washing, the membrane was incubated 
with $500 \mu \mathrm{L}$ of Biorad $^{\circledR}\left(\right.$ Hercules, CA, USA) Clarity ${ }^{\mathrm{TM}}$ Western ECL substrate (Cat.\# 170-5060) for 5 min before developing using Kodak ${ }^{\mathrm{TM}}$ M35 developer.

\subsection{8 dsDNA breaks assay (Gamma H2AX, $\gamma-\mathrm{H} 2 \mathrm{AX}$ )}

In order to determine the IR-induced dsDNA breaks (DSBs), we used the $\gamma-\mathrm{H} 2 \mathrm{AX}$ assay as described by Huang and Darzynkiewicz [180]. Briefly, after 6 Gy irradiation, cells were grown for 48 hours, enzymatically collected at different time points, resuspended in PBS and fixed with ice-cold 1\% methanol-free formaldehyde solution on ice for $15 \mathrm{~min}$. Cells were spun down and washed once with PBS, then resuspended in PBS and transferred to a tube containing ice-cold 70\% Ethanol and kept in $-20^{\circ} \mathrm{C}$. Collected samples were then spun and resuspended in BSA-T-PBS and spun again and resuspended in BSA-T-PBS at room temperature for $5 \mathrm{~min}$. Cells were spun and suspended in BSA-T-PBS containing $1 \mu \mathrm{g}$ of primary $\gamma-\mathrm{H} 2 \mathrm{AX}$ antibody (1/1500) from Abcam ${ }^{\circledR}$ (Cat.\# S139) and incubated for 1 hour at room temperature or overnight at $4^{\circ} \mathrm{C}$. Next day, cells were suspended in BSA-T-PBS containing 1/1000 v/v goat $F\left(a b^{\prime}\right) 2$ anti-rat IgG-FITC (Cat.\# F0104B, from R\& D System ${ }^{\circledR}$ ) and incubated in the dark at room temperature for 45 min with gentle shaking. After washing, cells were suspended in $1 \mathrm{~mL}$ of Propidium lodide (PI) staining solution and incubated for $30 \mathrm{~min}$ at room temperature in the dark. Then cells were analyzed by FC.

\subsubsection{Single stranded DNA (ssDNA) breaks (SSBs) assay (Comet assay)}

Comet assay was performed according to the reference [181]. In brief, aMSCs, 4T1, and NIH3T3-wt cells were irradiated with 6 Gy and kept in culture for different time points. $0.25,2$, and 24 hours after IR, cells were collected and mixed with melting 
agarose on hydrophilic plastic slips and treated with lysis buffer. After

electrophoresis, cells were fixed, stained with $\mathbf{P I}$, and examined under fluorescent microscope. Comet analysis was done for 75 single cells for each sample using Comet Assay IV ${ }^{\circledR}$ software (from Perceptive Instruments Ltd., Bury St Edmunds, UK).

\subsubsection{Apoptosis assay (Annexine-V)}

Annexin-V apoptosis kit from Santa $\mathrm{Cruz}^{\circledR}$ (Santa Cruz, CA, USA) was used for the assay (cat.\# sc-4252 AK). After 6 Gy irradiation, enzymatically harvested cells were washed twice with cold PBS, resuspended in 1X assay buffer at a concentration of 1 $X 10^{6}$ cells $/ \mathrm{mL}$, from which $100 \mu \mathrm{L}$ was transferred to a $5 \mathrm{~mL}$ tube containing $0.2 \mu \mathrm{g}$ of Annexin-V-FITC and $10 \mu \mathrm{L}$ of $\mathrm{PI}$, and incubated at room temperature for $15 \mathrm{~min}$. $400 \mu \mathrm{L}$ of $1 \mathrm{X}$ assay buffer were added to the samples before being analyzed by FC using BD FACS-Calibur ${ }^{\circledR}$ machine. $20 \mu \mathrm{M}$ Camptothecin (DNA-topoisomerase-I complex binding agent) was used as a positive control apoptotic agent for all time points.

\subsubsection{Cell cycle assay}

Enzymatically harvested cells, at different time points, were washed with $5 \mathrm{mM}$ EDTA in PBS and cell pellet was suspended in $5 \mathrm{mM}$ EDTA, then $3 \mathrm{~mL}$ of $100 \%$ Ethanol were added drop by drop during gentle vortexing. Cell pellet was suspended in PI solution prepared from PBS, $50 \mu \mathrm{g} / \mathrm{mL}$ PI (from Fluka ${ }^{\circledR}$, USA) and $20 \mu \mathrm{g} / \mathrm{mL}$ DNAse-free RNAse $\mathrm{A}$, and incubated for $30 \mathrm{~min}$ at $37^{\circ} \mathrm{C}$ in a staining density of $1 \times 10^{6}$ cells $/ \mathrm{mL}$ before analysis by $\mathrm{FC}$. 


\subsubsection{2 $\mathrm{RT}^{2}$ profiler PCR array}

Cells were cultured for 48 hours then irradiated with 6 Gy. Total RNA collection from $5 \times 10^{6}$ cells was performed 2 and 6 hours after IR using Qiagen RNeasy ${ }^{\circledR}$ Plus Mini RNA extraction and purification kit (Cat.\# 74134) according to the manufacturer's protocol (QIAGEN Inc. Canada, Toronto, ON, Canada). We used Qiagen ${ }^{\circledR}$ RT $^{2}$ First Strand Kit (Cat.\# 330401) for cDNA synthesis. PCR array was carried out using Qiagen ${ }^{\circledR} R T^{2}$ Profiler PCR Array Format-A for Mouse DNA Damage Signaling Pathway (Cat.\# PAMM-029ZC-2), Qiagen ${ }^{\circledR} \mathrm{RT}^{2}$ SYBR Green ROX qPCR Mastermix (Cat.\# 330520) and Applied Biosystems ${ }^{\circledR} 7500$ Fast PCR cycler (ABiosystems, Foster City, CA, USA). $\mathrm{RT}^{2}$ profiler PCR array data were analyzed by the online Qiagen ${ }^{\circledR} \mathrm{RT}^{2}$ Profiler PCR Array Data Analysis tool v3.5 after normalization and quality check.

\subsection{STATISTICS}

GraphPad Prism ${ }^{\circledR}$ software (version 5.01) was used for statistical analyses. Data were expressed as the mean $(\mathbf{M}) \pm$ the standard error of the mean (SEM). The paired two-tailed Student's t-test was applied for two sets of data. P-value $<0.05$ was considered a significant difference. 


\subsection{RESULTS}

\subsubsection{Irradiated aMSCs maintained their stem cells functionality and phenotype}

We isolated, expanded, and characterized BALB/c mice-derived aMSCs. Following exposure to ionizing radiation (IR) with doses of 2, 4, 6 Gy (Figure.4.8.2.1.Supp) and 8 Gy (Figure.4.5.1.I), irradiated aMSCs were still able to successfully differentiate to fatty acid binding protein-4 (FABP-4)-positive adipocytes showing their Oil-red-O-stained fat droplets, collagen-Il positive chondrocytes showing their phenotype-specific Alcian-Blue-stained sulphated mucin and Neutral-Red-stained lysosymes, and osteopontin-positive osteocytes showing their Alizarin-Red-stained calcium deposits. There was no significant difference in differentiation percentage (DP) between irradiated and non-irradiated cells, $p$-values were $0.3,0.8$ and 0.2 for differentiated adipocytes, chondrocytes and osteocytes, respectively. DP represented the average number of differentiated cells/total cells in 5 high-power fields.

FC analysis of irradiated aMSCs showed that they were constantly expressing FITClabelled surface antigens expected on MSCs (Sca1, CD106, CD105, CD73, CD29, CD44) when tested up to 7 days after IR in culture with corresponding percentages of up to $62.6 \%, 35.6 \%, 97.6 \%, 99.1 \%, 99.3 \%$, and $99.2 \%$ of FITC-positive cells, respectively. Isolated aMSCs were negative, as expected, for FITC-labelled HSC surface antigens (CD11b and CD45) with corresponding percentages of $1.05 \%$ and 1.27\% (Figure.4.5.1.II.A). After irradiation with 2, 4, 6 and 8 Gy, aMSCs maintained the expression of the MSCs expected surface antigens and stayed negative for the 
HSC-specific surface antigens for a period of up to 7 days after IR with no significant difference relative to non-irradiated cells (Figure.4.5.1.II.B). The expression percentages of FITC-positive aMSCs for different IR doses showed no significant difference for all tested time points as well (Figure.4.8.2.2.supp).

(A) BF

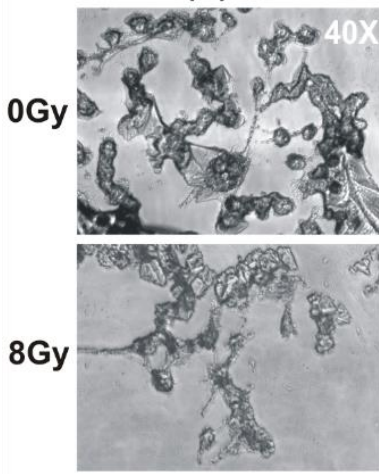

(D) BF

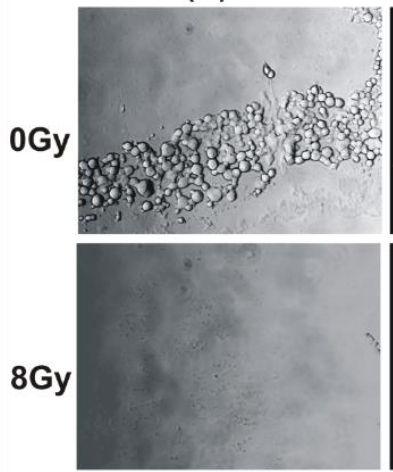

(G) BF

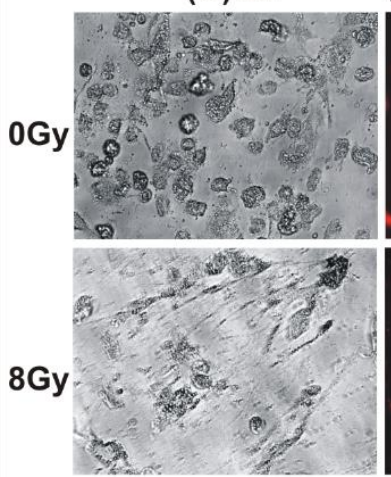

(B) FABP-4 +ve
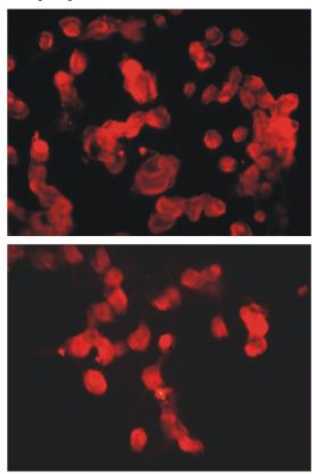

(E) Collagen-II +ve
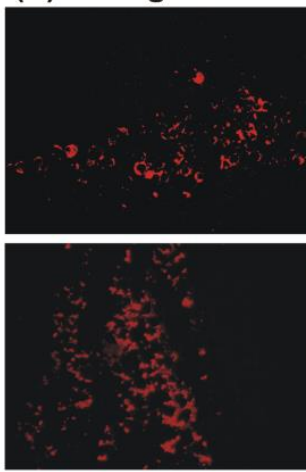

(H) Osteopontin +ve

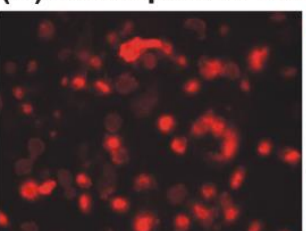

(F) Alcian Blue/NR

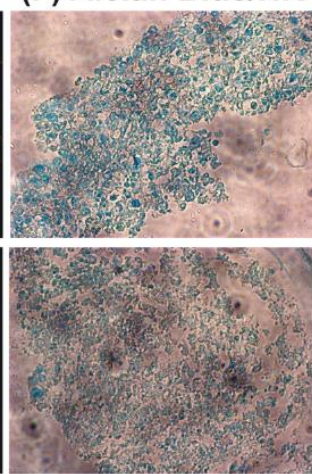

(I) Alizarin-Red

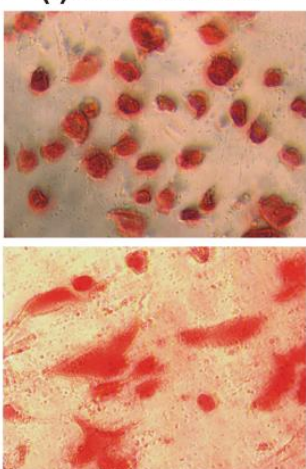


Figure.4.5.1.I: aMSCs multi-lineage differentiation after ionizing radiation

Exponentially growing aMSCs were differentiated to adipocytes $(A, B, C)$, chondrocytes $(D, E$, F), and osteocytes $(G, H, I)$ without irradiation ( $0 \mathrm{~Gy})$, and 24 hours after being irradiated with 8 Gy. After 14-21 days, cells were fixed and saved for immunohistochemistry (IHC). (A) Represents the bright field (BF) image of the corresponding mouse fatty acid binding protein4 (FABP-4)-positive newly formed adipocytes (red, FABP-4 +ve) shown in (B). (C) Represents the Oil-Red-O staining of the fat droplets inside newly formed adipocytes (dark red). (D) Represents the bight field (BF) image of the corresponding collagen-II positive newly formed chondrocytes (red) shown in (E). (F) Represents the Alcian-Blue staining of sulphated mucin (blue) and Neutral Red (NR) staining of the lysozymes (red) inside newly formed chondrocytes. $(\mathrm{G})$ Represents the bight field (BF) image of the corresponding osteopontinpositive newly formed osteocytes (red, Osteopontin +ve) shown in (H). (I) Represents the Alizarin-Red staining of calcium deposits inside newly formed osteocytes (red). Images magnification is $40 X$. 

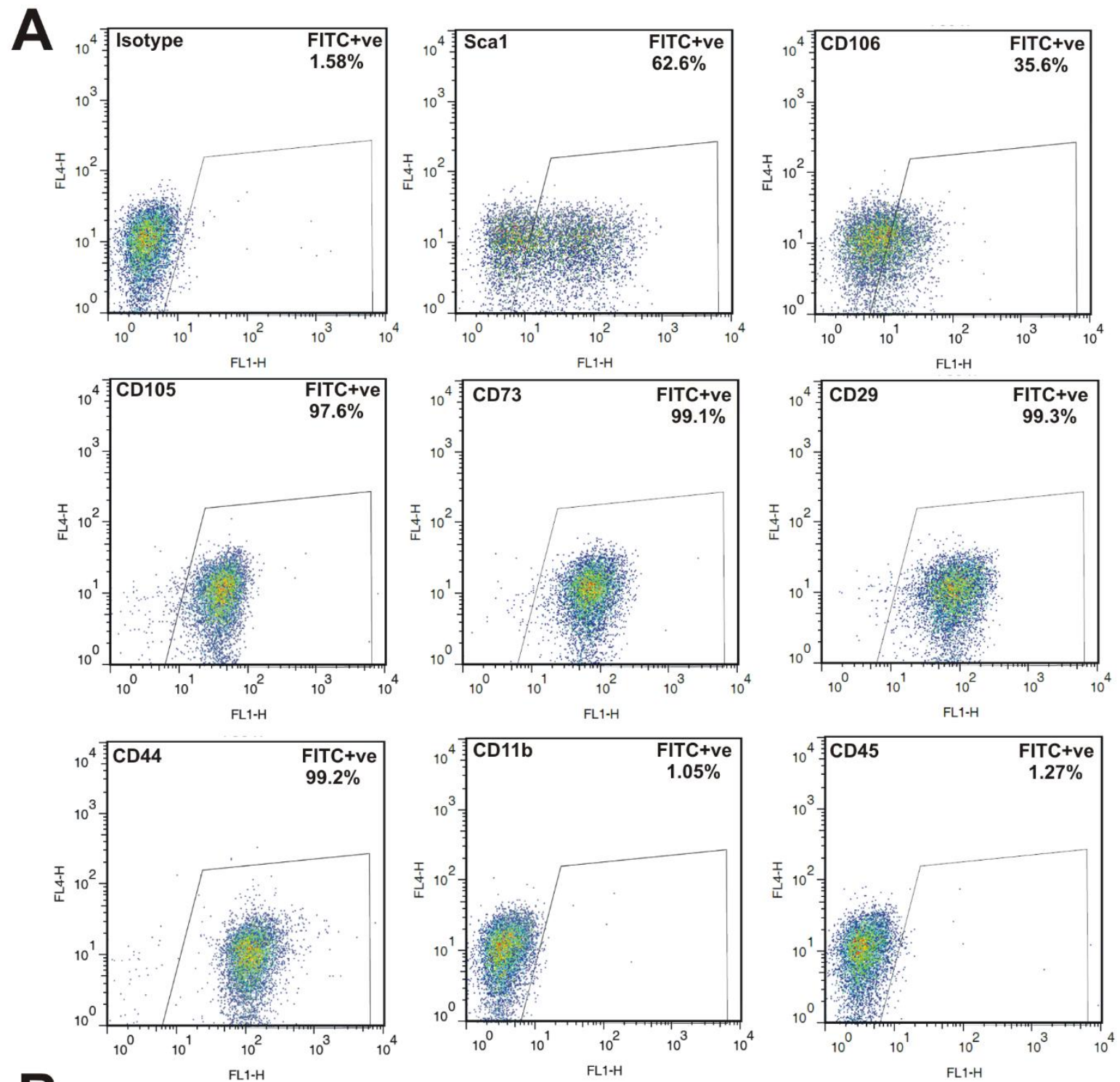

B

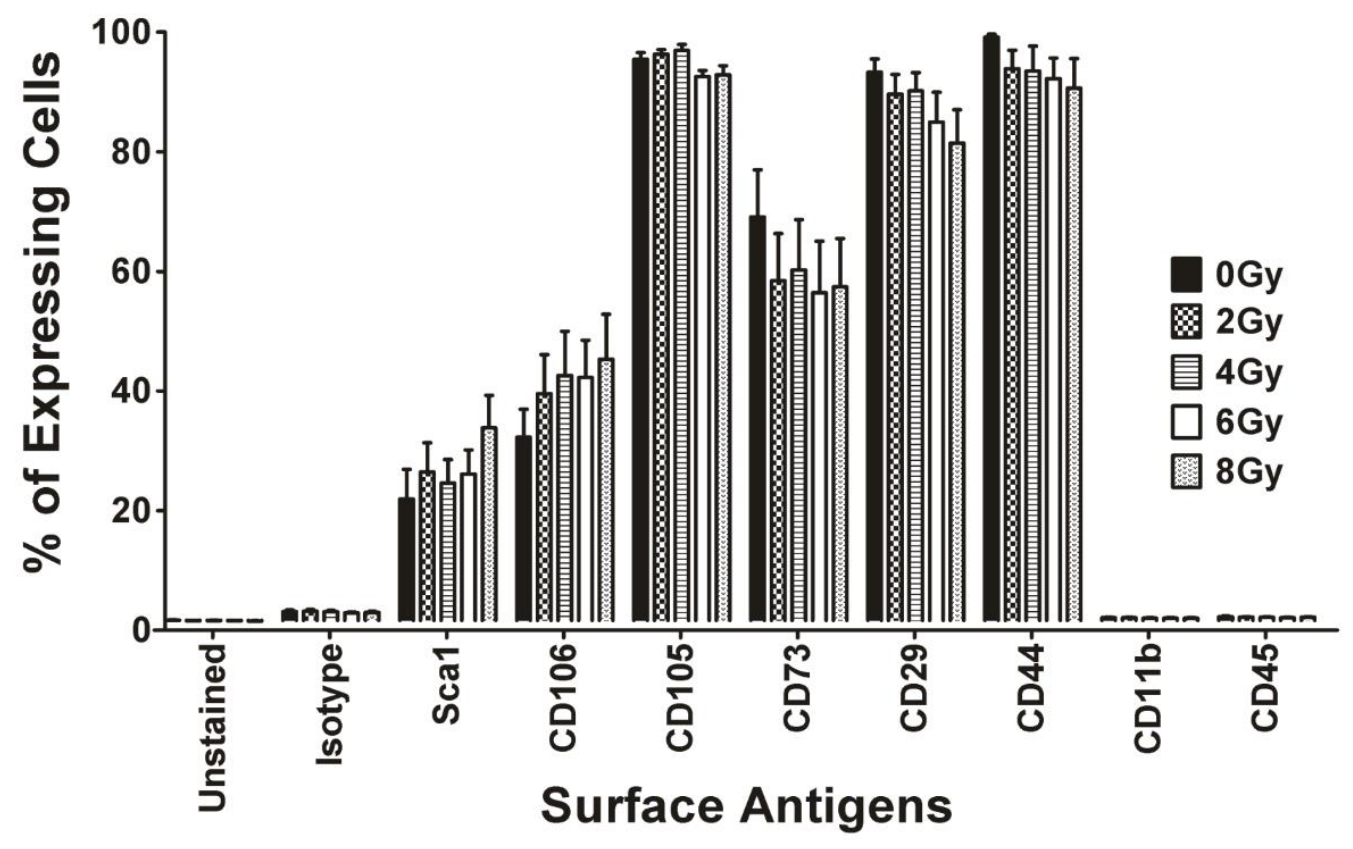


Figure.4.5.1.II: Flow cytometry (FC) analysis of aMSCs with and without irradiation Non-irradiated aMSCs were analyzed by FC after being cultured for different time points (ranging between $6-168$ hours, see Figure.4.8.2.2.Supp) for assessing the expression of surface antigens often seen on Mesenchymal Stromal/Stem Cells (MSCs), i.e. Sca1, CD106, CD105, CD73, CD29 \& CD44, as well as those absent on MSCs since typical of Hematopoietic Stem Cells (HSCs), i.e. CD11b and CD45 (A) with the percentages of expressing cells. (B) Represents the surface antigens expressions of on MSCs without irradiation and after being irradiated with 2, 4, 6 and $8 \mathrm{~Gy}$. $(\mathrm{n}=4)$, data presented as the mean \pm the standard error of the mean (SEM).

\subsubsection{Clonogenic Capacity of irradiated aMSCs}

To determine the clonogenic capacity of irradiated aMSCs, we performed a clonogenic assay. aMSCs irradiated with 2, 4, 6 and 8 Gy, and kept for 10 days in culture, showed higher relative survival fractions (rSF) when compared to those of 4T1 and NIH3T3-wt, with significant differences $(p$-value $<0.05)$ documented at all IR doses used (Figure.4.5.2). The plating efficiency (PE) of aMSCs was comparable to that of $4 \mathrm{~T} 1$ and much higher than that of NIH3T3-wt (Table.4.8.1.1). P-values were always lower than 0.05 for all radiation doses within each cell type. 

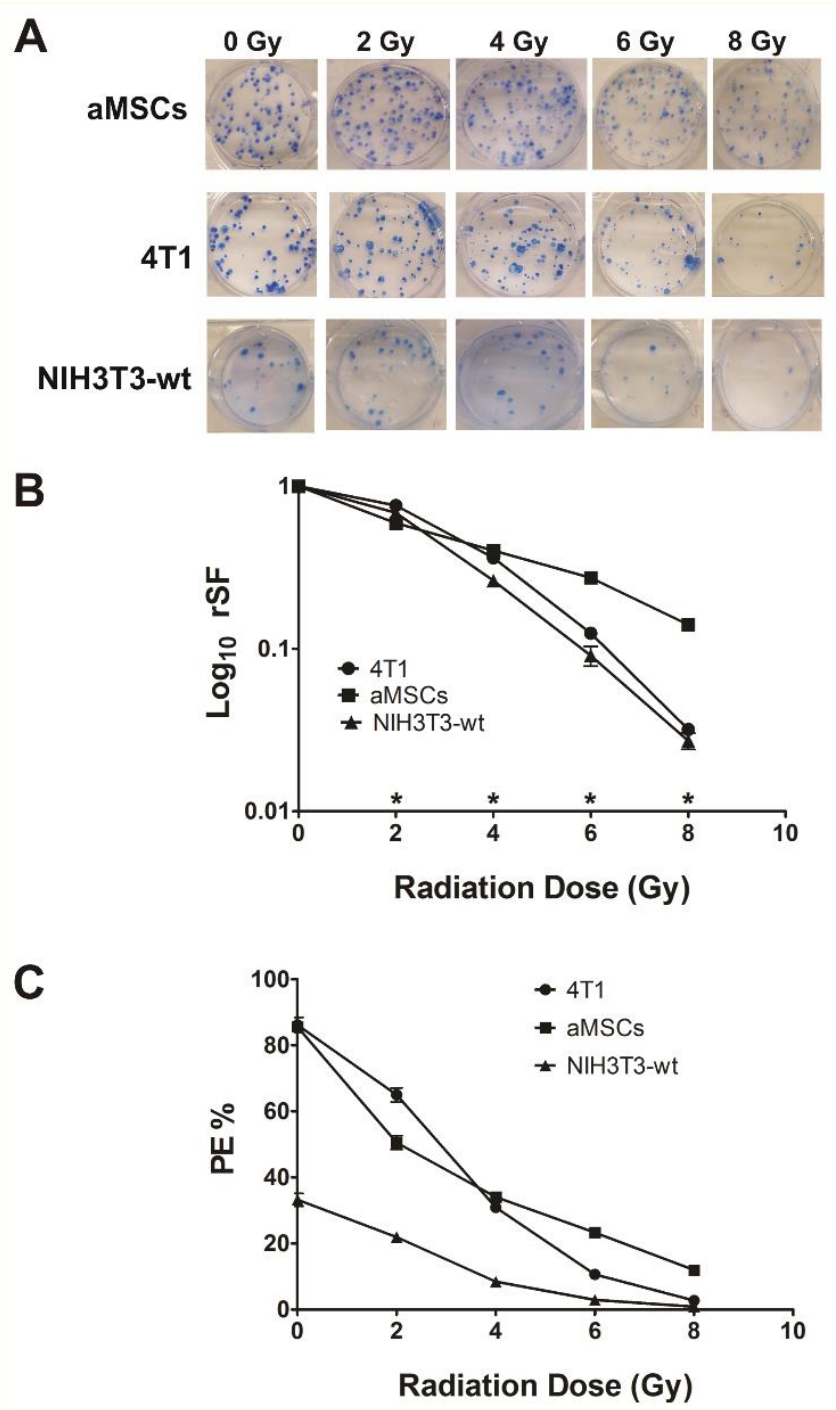

Figure.4.5.2: Clonogenic capacity of irradiated aMSCS

aMSCs, 4T1 and NIH3T3-wt cells were plated in 6 well plates for clonogenic assay, and after 24 hours cells were irradiated with 2, 4, 6 and 8 Gy and kept in culture for 10 days. (A) Represents the images of the formed colonies in a single well with different radiation doses used for all cell types. (B) Represents the calculated averages of the relative survival fraction (rSF). (C) Represents the average of the platting efficiency (PE) obtained for all cell types. $(n=3), *$ = value $<0.05$ and data presented as the mean \pm the standard error of the mean (SEM). 


\subsubsection{Radiation-induced DNA damage and repair in aMSCs}

To study DSBs induction and repair after IR, we used FC analysis to compare the cellular level of $\gamma-\mathrm{H} 2 \mathrm{AX}$ (DSBs and dsDNA repair marker) in aMSCs, 4T1 and NIH3T3-wt. Irradiated aMSCs showed a significantly higher ( $p$-value $<0.00005)$ and faster (as early as 0.25 hour after IR) rise in $\gamma-\mathrm{H} 2 \mathrm{AX}$ level after IR when compared to irradiated 4T1 and NIH3T3-wt cells (Figure.4.5.3.A). Moreover, aMSCs showed a significantly earlier peak of $\gamma-\mathrm{H} 2 \mathrm{AX}$ level ( $\mathrm{p}$-value $<0.005$, at 2 hours after IR) than that of $4 \mathrm{~T} 1$ cells, for which the peak was delayed until 12 hours after IR. By 48 hours after IR, the significant drop in $\gamma-\mathrm{H} 2 \mathrm{AX}$ was more evident in aMSCs than in both 4T1 and NIH3T3-wt cells (Figure.4.5.3.A).

At the gene expression level, within 2 hours after IR, irradiated aMSCs showed up regulation of $62 \%, 50 \%, 62.5 \%, 60 \%, 64 \%, 63 \%, 70 \%$ and $56 \%$ of the following gene categories: ATM/ATR signaling, nucleotide-excision repair (NER), baseexcision repair (BER), mismatch repair (MMR), double stranded DNA break repair (dsDNAR); [including homologous recombination repair (HRR), non-homologous end-joining repair (NHEJR)], and other DNA repair pathways gene categories, respectively. Interestingly, aMSCs showed the highest percentages of up regulated DNA repair-related genes among all irradiated cell types; the 4T1 and NIH3T3-wt (Figure.4.5.6.A, B and Table.4.8.1.2 and 4.8.1.3).

At the protein level, IR dose-dependent phosphorylation of ataxia telangiectasiamutated kinase (ATM) is more evident in irradiated aMSCs compared to 4T1 and occurs as fast as 0.5 hour after IR exposure. Also, after IR, there was an evident up regulated expression of DNA-dependent protein kinase catalytic subunit (DNA- 
PKcs) and RAD51 protein that occurred as fast as 0.5 hour after IR exposure to levels comparable to those of irradiated 4T1 (Figure.4.5.3.B).

We noted that the up regulated expression of most of the tested aMSCs DNA repair genes disappeared within 6 hours after IR (Figure.4.5.6 and Table.4.8.1.2 and

\subsubsection{3).}

We also reported that most of the single stranded DNA breaks (SSBs) repair in irradiated aMSCs was achieved within the first two hours after IR in a comparable manner to 4T1 and NIH3T3-wt cells (Figure.4.5.3.C).

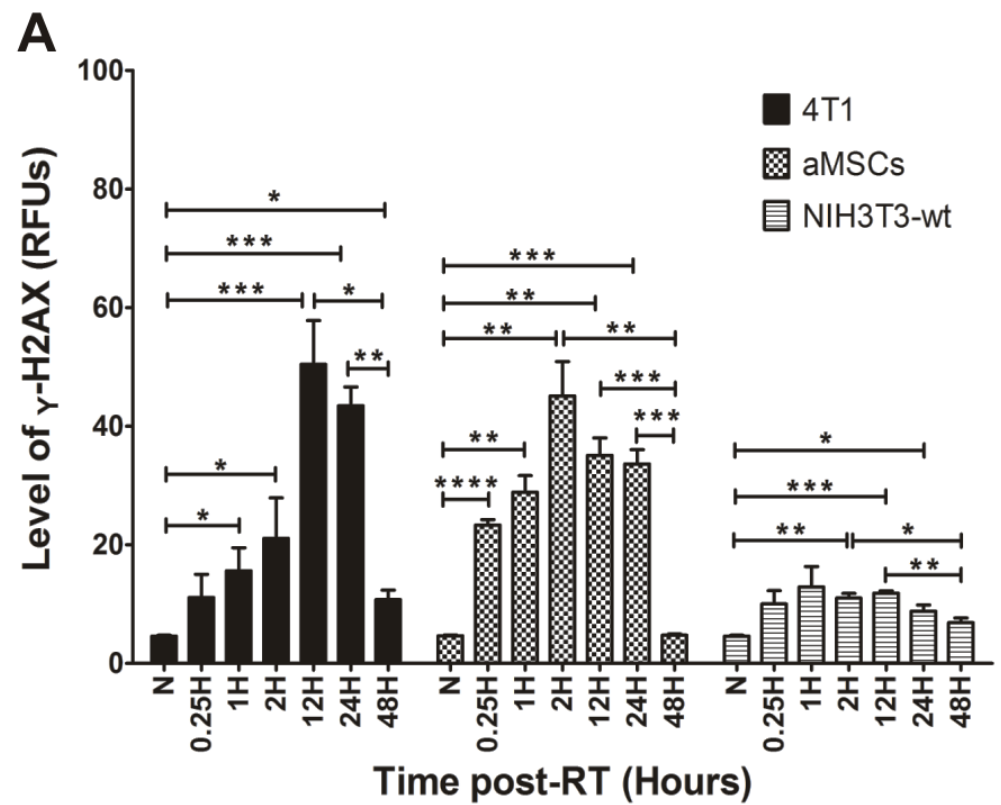


B

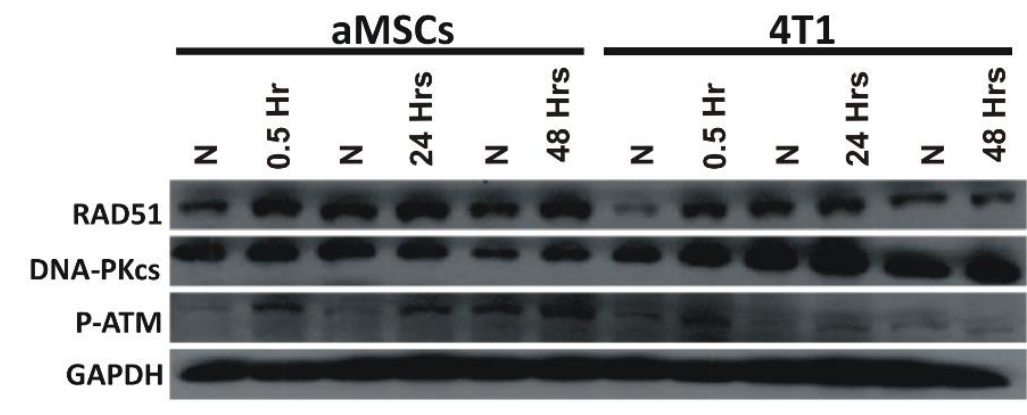

aMSCs

4T1
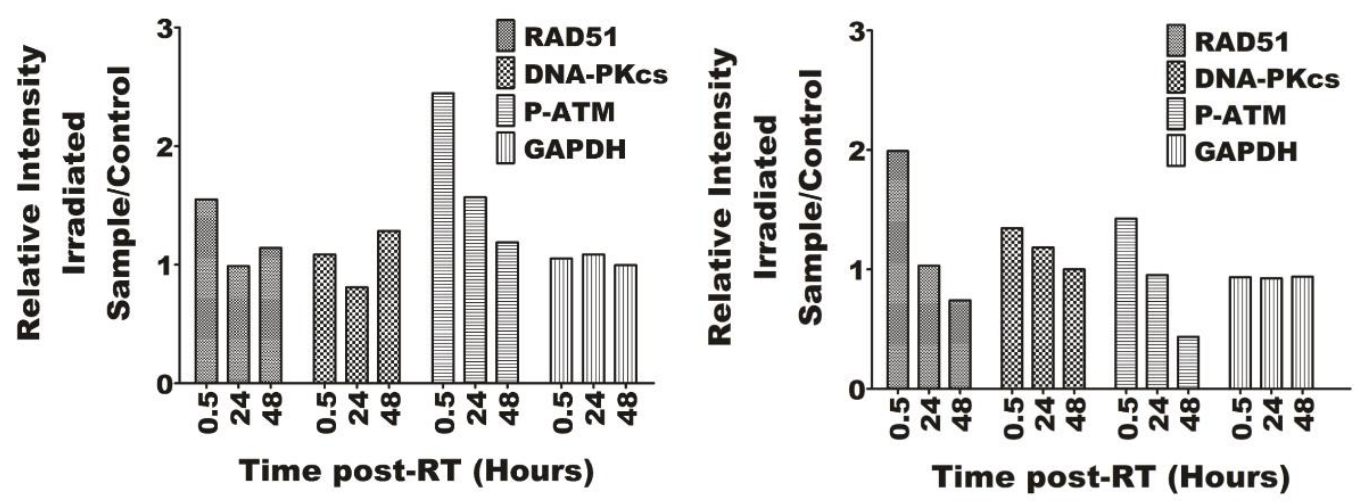

C
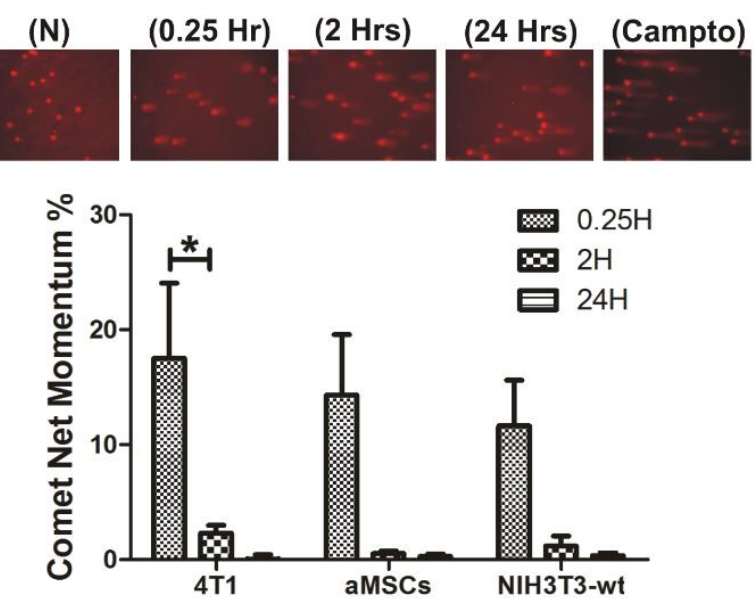


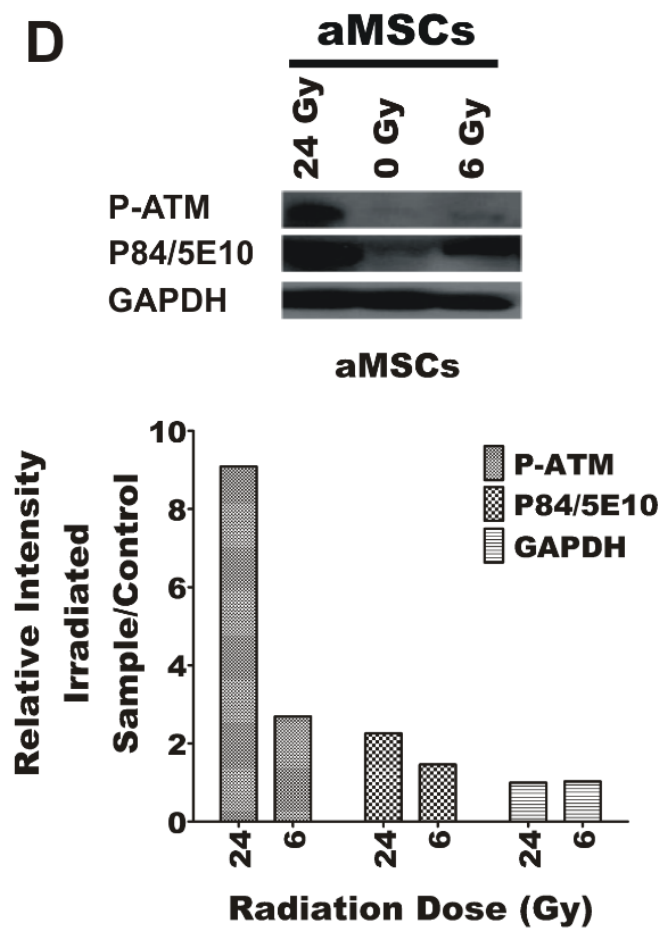

Figure.4.5.3: dsDNA damage assay of aMSCs

(A) Exponentially growing 4T1, aMSCs and NIH3T3-wt cells were irradiated with 6 Gy. Cells were analyzed by FC for $\gamma$-H2AX (as the double stranded DNA (dsDNA) damage and repair marker) at different time points after IR $(0.25,1,2,12,24$ and 48 hours). Non-irradiated control (N) was calculated as $\boldsymbol{\gamma}$-H2AX level $<0.05$ RFU to which, all irradiated cells were compared. $\boldsymbol{\gamma}$-H2AX level is presented in RFUs (Relative Fluorescence Units). ( $n=3), *=P$-value $<0.05, * *=$-value $<0.005, * * *=\mathrm{P}$-value $<0.0005, * * * *=\mathrm{P}$-value $<0.00005$ and data presented as the mean \pm the standard error of the mean (SEM).

(B) aMSCs and 4T1 cells cultured for 48 hours were irradiated with 6 Gy. 0.5, 24 and 48 hours after IR, cells were lysed and total protein was collected. After protein measurement, $25 \mu \mathrm{g}$ protein were used for western blot. We tested the comparable expression of RAD51 and total DNA-PKcs, which are the main markers for HR and NHEJ DNA repair pathways, 
respectively, together with the expression of ATM phosphorylation ( $p-A T M)$ as well. Protein expression was quantified by comparing the relative intensity of the blot bands using ImageJ $^{\circledR}$ software. Glyceraldehyde-3-phosphate dehydrogenase (GAPDH) was used as an endogenous control.

(C) Exponentially growing 4T1, aMSCs and NIH3T3-wt cells were irradiated with 6 Gy. Comet assay analysis was pursued for 75 cells from each cell type sample at different time points (0.25, 2 and 24 hours after IR) for IR-induced single stranded DNA (sSDNA) breaks (SSBs). After averaging, the net tail momentum was calculated after subtracting the normalization control. (N) Represents images of non-irradiated aMSCs followed by images of irradiated aMSCs comets at different time points. $100 \mu \mathrm{M}$ Camptothecin-treated cells (Campto) for 12 hours were used as positive DNA damaging control. $(n=3), *=$ P-value $<0.05$. Data presented as the mean $(M) \pm$ the standard of the mean (SEM).

(D) Exponentially growing aMSCs were irradiated with 6 and 24 Gy. 0.5 hour after IR, cells were lysed and total protein was collected. After protein measurement, $25 \mu \mathrm{g}$ protein were used for western blotting. We tested the compared expression of p-ATM and P84/5E10 after low (6 Gy) and high (24 Gy) IR doses. Protein expression level was quantified by comparing the relative intensity of the blot bands using ImageJ ${ }^{\circledR}$ software. Glyceraldehyde-3-phosphate dehydrogenase (GAPDH) was used as an endogenous control.

\subsection{4 aMSCs radiation-induced apoptotic response}

To investigate IR-induced apoptosis, cells were irradiated with 6 Gy and analyzed by FC at different time points after IR exposure (12, 24 and 48 hours) and after being 
stained for Annexin-V and PI. Collectively, irradiated aMSCs showed the lowest early and late apoptotic response among other irradiated cells

(Figure.4.8.2.3.Supp). The peak of early apoptotic aMSCs was noted 24-48 hours after IR. However, in irradiated 4T1 cells, early apoptotic cells continue to increase up to 48 hours (Figure.4.8.2.3.Supp).

In addition, out of 16 apoptosis-related genes, there was an up regulation of $38 \%$ of apoptosis-related genes within 2 hours after IR in irradiated aMSCs compared to $50 \%$ and $5 \%$ for irradiated $4 \mathrm{~T} 1$ and NIH3T3-wt cells, respectively. We noted the disappearance of this up regulated expression within 6 hours after IR in aMSCs (Figure.4.5.6.A and $B$ and Table.4.8.1.2 and 4.8.1.3).

\subsubsection{Radiation-induced cell cycle changes in aMSCs}

aMSCs, 4T1 and NIH3T3-wt cells were irradiated with 6 Gy and analyzed by FC at different time points $(6,12,24$ and 48 hours) after IR exposure and after being stained with PI to document the IR-induced CC dynamics. At the resting condition, most of the aMSCs (around 55\%) were in G1 phase and the remaining aMSCs shared the $S$ and $G 2 / M$ phase ( $S=25 \%$ and $G 2 / M=20 \%$ ) (Figure.4.5.5.A and B). 6 hours after IR, aMSCs documented significant rise ( $p$-value $<0.05)$ and earlier peak (compared with $4 \mathrm{~T} 1$ cells) in the percentage of G2/M arrest phase (up to $45 \%$ ), which was maintained significant up to 24 hours after IR. While by 48 hours, irradiated aMSCs G2/M arrest showed no significant difference from the resting condition. 6 hours after IR, we noted a significant drop in G1 phase in aMSCs (down to $30 \%$ ), however, it started to rise back to normal level gradually until 48 hours after 
IR. We saw a single significant fall in S phase, only at 12 hours after IR in aMSCs (Figure.4.5.5.B).

2 hours after IR, the gene expression of irradiated aMSCs showed up regulation of $100 \%, 100 \%, 53 \%, 43 \%$ and $33 \%$ of the following gene categories: S phase/DNA replication, G2/M transition, CC checkpoints/Arrest, CC regulators and negative CC regulators genes, respectively (Figure.4.5.6.C and Table.4.8.1.2). The percentage of up regulated CC-related genes in aMSCs was the highest (47\%) compared to those of irradiated $4 \mathrm{~T} 1$ and $\mathrm{NIH} 3 \mathrm{~T} 3$-wt, which was $40 \%$ and $10 \%$, respectively (Figure.4.5.6.B). This up regulated expression disappeared within 6 hours after IR in aMSCs (Figure.4.5.6.D and Table.4.8.1.2).

In 4T1 cells, most of the cells at the resting condition were in S phase (approximately 55\%) and the rest of the cells shared G1 and G2/M phases almost equally. Although they showed a significant rise $(P$-value $<0.005)$ of $G 2 / M$ arrest as early as 6 hours after IR, irradiated 4T1 cells G2/M arrest peak was delayed until 12 hours after IR and it failed to maintain the significant difference beyond that (however, the peak was maintained in irradiated aMScs for 24 hours after IR). By 48 hours after IR, irradiated 4T1 G2/M phase dropped to its normal level. However, we noted a significant rise in $\mathrm{G} 1$ arrest at 48 hours after IR. We also noted that the $\mathrm{S}$ phase in 4T1 cells continued to significantly decline starting from 12 hours after IR $(p$-value $<0.005)$ and continued to drop significantly until 48 hours after IR and never returned to normal level (however, irradiated aMSCs have no significant drop in S phase starting from 24 hours after IR) (Figure.4.5.5.C). NIH3T3-wt cells showed 
only two significant G2/M arrest peaks at 6 and 12 hours after IR (Figure.4.5.5.D).
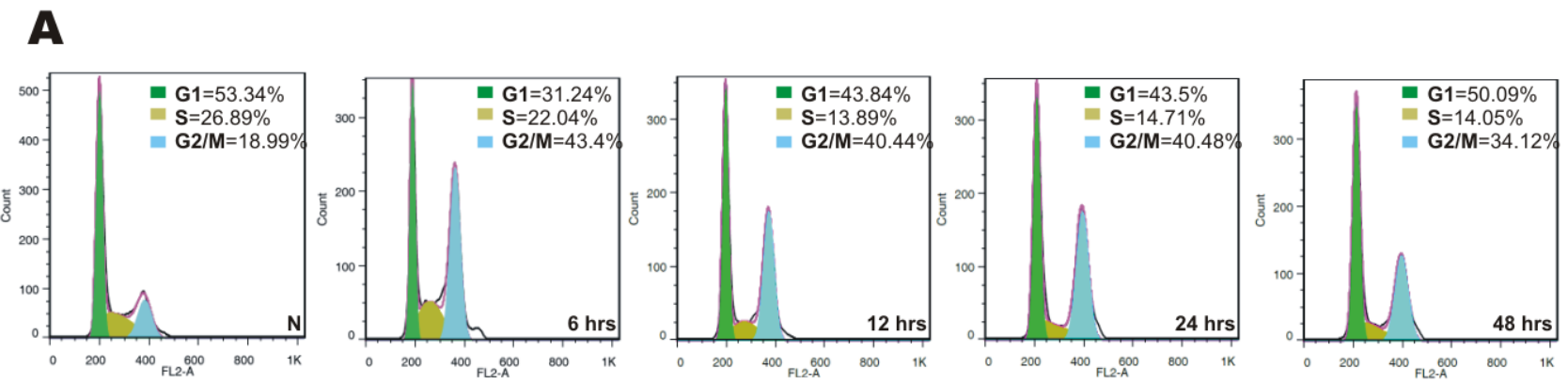

B

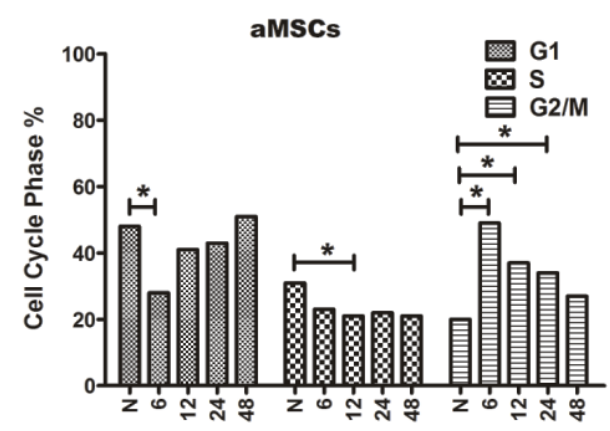

Time post-RT (Hours)

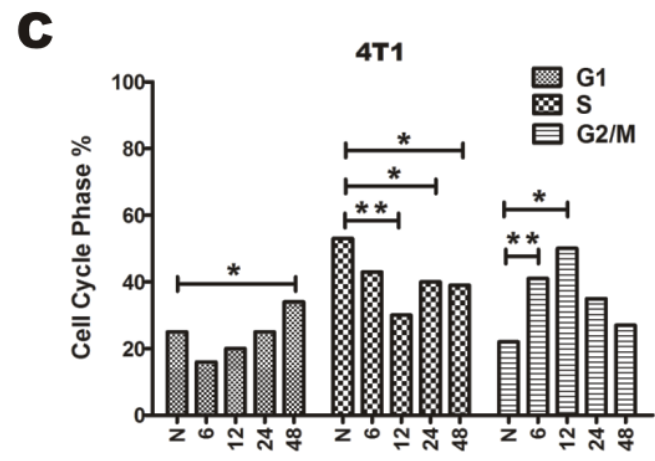

Time post-RT (Hours)

D

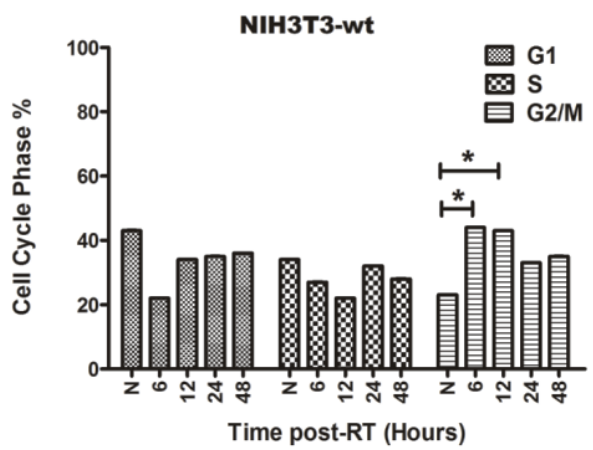

Figure.4.5.5: Cell cycle assay by flow cytometry

Exponentially growing aMSCs, 4T1 and NIH3T3-wt were irradiated with 6 Gy and kept in culture. After 6, 12, 24 and 48 hours after IR, cells were stained with PI for cell cycle flow cytometry (FC) analysis. (A) Represents cell cycle analysis of one experiment of aMSCs, ( $N=$ non-irradiated cells). (B), (C) and (D) Represent average of three experiments ( $n=3$ ) of each of 
aMSCs, 4T1 \& NIH3T3-wt, respectively. $(n=3) .{ }^{*}=$ P-value $<0.05$ and ${ }^{* *}=$ P-value $<0.005$.

Data presented as the mean \pm the standard error of the mean (SEM).

\begin{tabular}{|c|c|c|c|c|c|c|c|c|c|c|c|c|}
\hline Layout & 01 & 02 & 03 & 04 & 05 & 06 & 07 & 08 & 09 & 10 & 11 & 12 \\
\hline A & Abl1 & Apex1 & Atm & Atr & Atrx & Bax & Blm & Brca1 & Brca2 & Brip1 & Cdc25a & Cdc25c \\
\hline B & Cdkn1a & Chek1 & Chek2 & Dclre1a & Ddb2 & Ddit3 & Ercc1 & Ercc2 & Exo1 & Fanca & Fancc & Fancd2 \\
\hline C & Fancg & Fen1 & Gadd45a & Gadd45g & H2afx & Hus1 & Lig1 & Mbd4 & Mcph1 & Mdc1 & Mgmt & Mif \\
\hline D & MIh1 & MIh3 & Mpg & Mre11a & Msh2 & Msh3 & Nbn & Nthl1 & Ogg1 & Parp1 & Parp2 & Pcna \\
\hline E & Pms2 & Pole & Polh & Poli & Ppm1d & Ppp1r15a & Prkdc & Pttg1 & Rad1 & Rad17 & Rad18 & Rad21 \\
\hline $\mathbf{F}$ & Rad50 & Rad51 & Rad51c & Rad51b & Rad52 & Rad9a & Rev1 & Rnf8 & Rpa1 & Smc1a & Smc3 & Sumo1 \\
\hline G & Terf1 & Topbp1 & Trp53 & Trp53bp1 & Ung & Wrn & Xpa & Xpc & Xrcc1 & Xrcc2 & Xrcc3 & Xrce6 \\
\hline
\end{tabular}

\section{aMSCs 2 Hours}
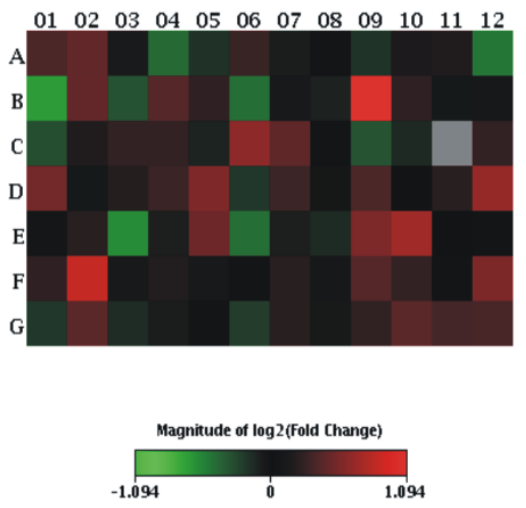

\section{T1 2 Hours}
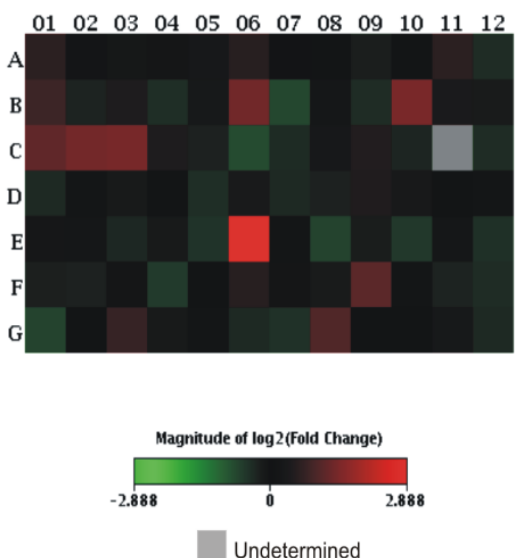

\section{aMSCs 6 Hours}
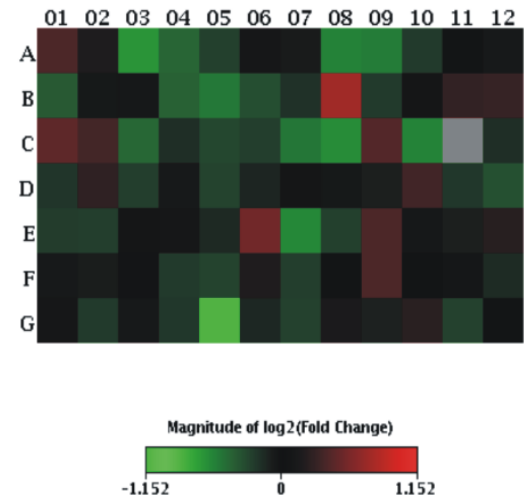

NIH3T3-wt 2 Hours
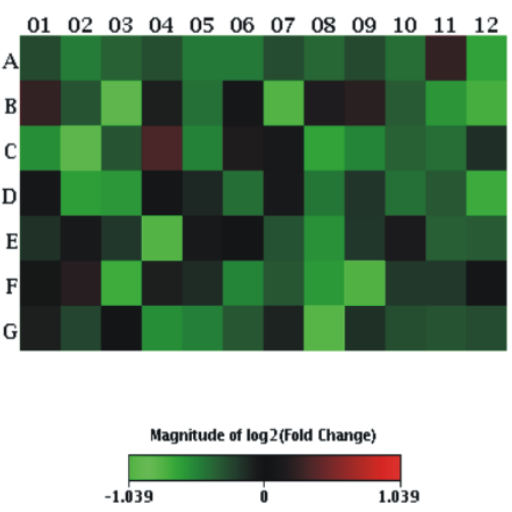
B
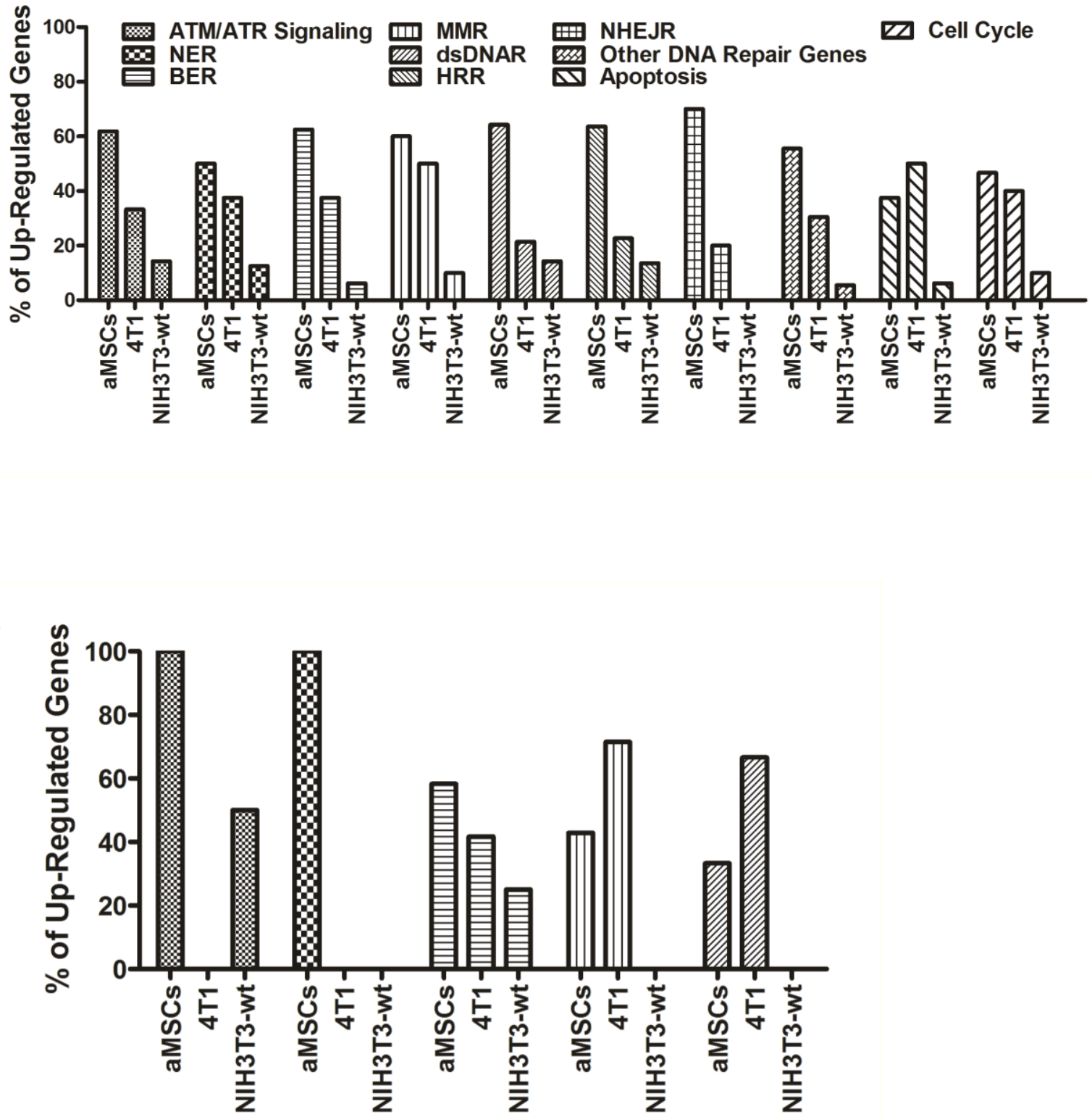

S-Phase/DNA replication 0 Other CC Regulators

G2/M Transition

III Negative CC Regulators

曰CC checkpoints/Arrest 


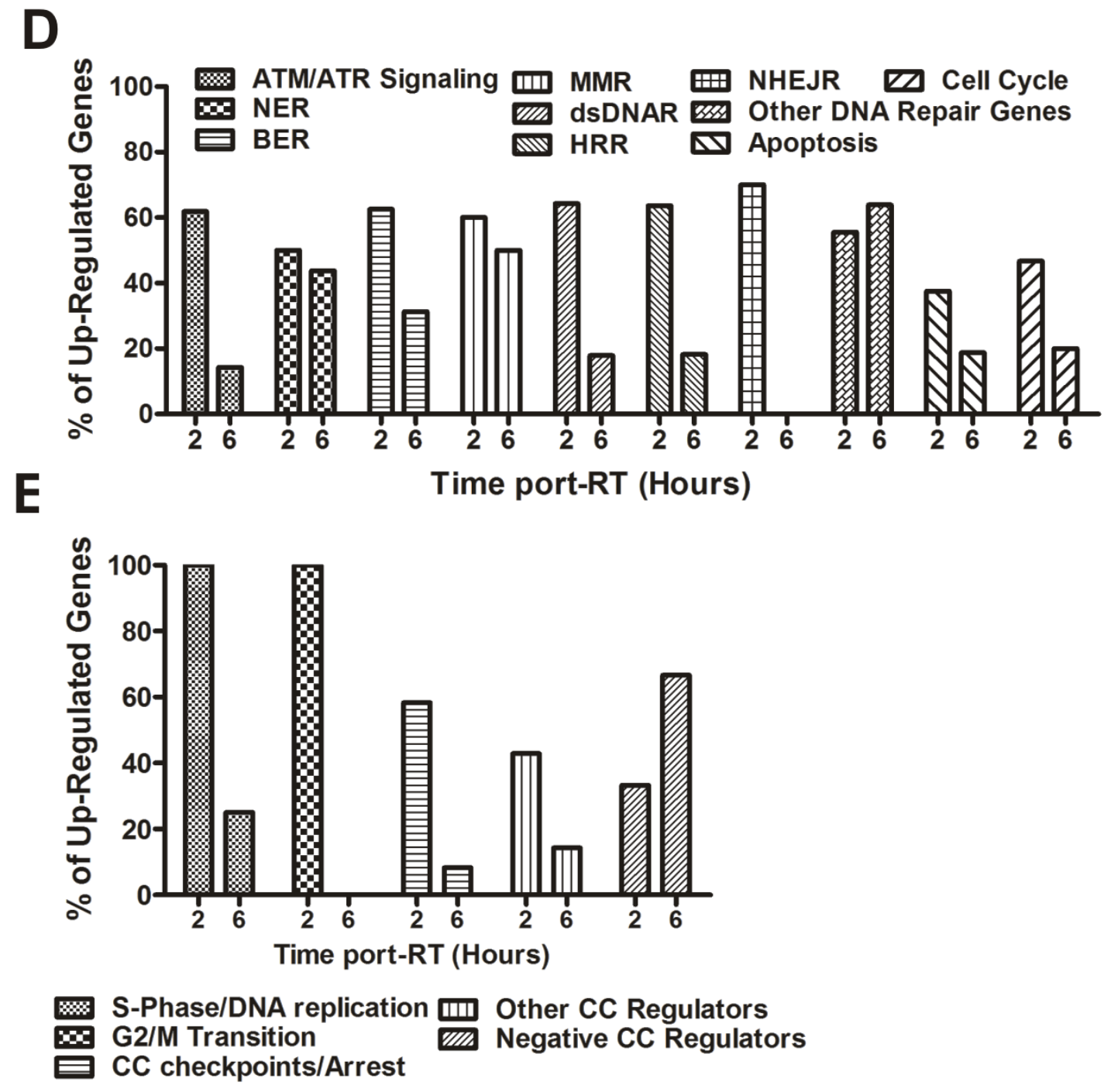

Figure.4.5.6: PCR array of gene expression for DNA damage/repair signaling pathways Exponentially growing aMSCs, 4T1 and NIH3T3-wt cells were irradiated with $6 \mathrm{~Gy}$, and RNA collected 2 hours after IR exposure. After cDNA generation, PCR array was performed and results were analyzed by $R T^{2}$ Profiler PCR Array Data Analysis v3.5 online tool. (A) Represents the array plate setup and the heat map for up regulated (Red) [>1 fold change, according to the array kit manufacturer's recommendations] and down regulated (Green) [ 1 fold 
change] genes 2 hours after IR in all irradiated cells and 6 hours after IR for aMSCs only. The color scale showed the magnitude of the log2 of the fold change of gene expression. (B) Represents the expression percentage of up regulated genes in each category of the tested genes of DNA damage/repair signaling pathways as follows: ATM/ATR signaling, nucleotide excision repair (NER), base excision repair (BER), mismatch repair (MMR), double-stranded DNA repair (dsDNAR); [including: homologous recombination repair (HRR), non-homologous end-joining repair (NHEJR)], other DNA repair genes, apoptosis and cell cycle. (C) Represents the expression percentage of up regulated genes in each gene category associated with different cell cycle $(\mathrm{CC})$ regulatory steps, which include: S phase/DNA replication, G2/M transition, $\mathrm{CC}$ checkpoints/Arrest, $\mathrm{CC}$ regulators and negative $\mathrm{CC}$ regulators. (D) Represents the expression percentage of up regulated genes in each gene category associated with the tested DNA damage/repair signaling pathways in irradiated aMSCs 2 vs 6 hours after IR. (E) Represents the expression percentage of up regulated genes in each gene category associated with different CC regulatory step in irradiated aMSCs 2 vs 6 hours after IR. The five genes; Actin beta (ACTB), Beta-2 microglobulin (B2M), Glyceraldehyde-3-phosphate dehydrogenase (GAPDH), Glucuronidase beta (GUSB) and Heat shock protein 90 alpha (cytosolic) class B member 1 (HSP9OAB1) were used as endogenous house-keeping genes. $(n=1)$ and all tested genes are listed and identified in Tables.4.8.1.2 and 4.8.1.3.

\subsection{DISCUSSION}

We examined the radio-biological response of mouse aMSCs in comparison to a highly metastatic mesenchymal-like triple negative mouse breast cancer 4T1 cell line 
as a cancer cell model which possesses a considerable population of CSC [109, 182] with its evident resistance to IR $[110,183]$; a resistance that is hypothesized to be mediated by G2/M arrest [110], and normal mouse fibroblast NIH3T3-wt cell line as a normal cell model after exposure to IR.

Within 2 hours after IR, gene expression profiling showed that irradiated aMSCs had the highest percentages of up regulated DNA damage/repair and CC related genes in all tested gene categories. These findings matched with the significant earlier peak level of $\gamma-\mathrm{H} 2 \mathrm{AX}$, as the DNA damage and repair marker [180], in irradiated aMSCs 2 hours after IR compared to those of 4T1 and NIH3T3-wt, as their peak was later at 12 hours after IR. These findings could explain the higher rSF, PE and clonogenicity of irradiated aMSCs compared to those of 4T1 and NIH3T3-wt after exposure to IR with doses up to 8Gy. That conclusion was supported by the lower IR-induced apoptotic response of aMSCs, up to 48 hours after IR, than those of $4 \mathrm{~T} 1$ and NIH3T3-wt, and the lower percentage of up regulated pro-apoptotic genes, within 2 hours after IR, than that of $4 \mathrm{~T} 1$ cells.

On the protein level, irradiated aMSCs showed a dose-dependent ATM phosphorylation pattern, a finding that was recorded in a previous study in irradiated MSCs from bone marrow origin [95]. Irradiated aMSCs ATM phosphorylation was higher than that of $4 \mathrm{~T} 1$ and as fast as 0.5 hours after IR. We found that, ATM phosphorylation in irradiated aMSCs kept slightly detectable up to 24 hours, which might explain the significantly maintained G2/M arrest that lasted up to 24 hours after IR. This finding has been hypothesized as a mechanism of IR resistance in CSC of 4T1 cells [110]; since ATM is the most proximal initiating step in signal 
transduction for CC regulation to allow the DNA repair in irradiated cells [95, 96, 106]. That might be also explained by the early up regulation of most CC regulator genes; e.g. ABL1, ATM, CDC25A, CHEK1, GADD45A, HUS1, MRE11A, MSH2, NBN, PPM1D, RAD9A, RAD17, RAD51, and TP53BP1, in irradiated aMSCs. Similar gene expression changes were documented in a similar study in irradiated MSCs from bone marrow origin [184]. When categorized, we found that the up regulated genes related to S phase/DNA replication were MRE11A, MSH2, RAD17, RAD51; to G2/M transition were CHEK1, PPM1D; and to CC check points/arrest were CHEK1, GADD45A, HUS1, MSH2, NBN, PPM1D, RAD9A) within 2 hours after IR (Table.4.8.1.2). In a previous study. it has been documented that, breast CSC have much higher ATM, and Chek1 levels compared to differentiated tumor cells [185]. In addition to that, it was previously concluded in previous studies that, p84/5E10 (the nuclear protein encoded by the N5 gene) induces an ATM-independent G2/M $\mathrm{CC}$ arrest before it induces p53-independent apoptosis that is inhibited by retinoblastoma $(\mathbf{R b})$ tumor suppressor protein $[186,187]$. In this regard, we found an IR dose-dependent up regulated expression of $\mathrm{p} 84 / 5 \mathrm{E} 10$ protein that was more evident in aMSCs (Figure.4.5.4.D).

Taken together, these findings demonstrate that G2/M arrest in irradiated aMSCs is achieved by both $p$-ATM dependent and p-ATM-independent (p84/510E mediated) pathways suggesting the significant role of G2/M arrest in IR-induced DNA damage, which looks to be more superior in aMSCs than that in $4 \mathrm{~T} 1$ cells.

Since RAD51 and DNA-PKcs are considered the main player proteins for HR and NHEJ repair of DSBs, respectively (HRR, NHEJR) [106], we were interested in 
assessing their levels after IR exposure. Protein study showed that irradiated aMSCs had comparable levels of RAD51 and total DNA-PKcs to those of irradiated 4T1. However, the gene expression profiling showed higher percentages of up regulated HRR-related genes, e.g. CHEK1, EXO1, FANCD2, HUS1, LIG1, MLH1, MRE11A, RAD51, RAD52, RPA1, TP53BP1, XRCC2, XRCC3, and NHEJR-related genes, e.g. DCLRE1A, FEN1, MRE11A, NBN, RAD50, XRCC6 [Ku70], in irradiated aMSCs compared to those of irradiated 4T1 (Table.4.8.1.2). These findings showed that both HRR, which functions only during $S$ and G2/M phases, and NHEJR, which functions during all CC phases $[99,188]$, are significantly activated DNA repair pathways in irradiated aMSCs. They are in agreement with what has been shown in a previous study on MSCs from bone marrow origin [95]. In addition, a shift in aMSCs IR-induced DSBs repair towards HRR side would be suggested by the significant up regulation of IR-induced G2/M arrest, where HRR dominates, and by the early significant down regulation of G1 arrest in irradiated aMSCs. Moreover, we documented up regulation of other gene categories responsible for other DNA repair pathways, mainly ATM/ATR, NER, BER, MMR and other DNA repair pathways in irradiated aMSCs. Furthermore, most of single stranded DNA breaks (SSBs) repair was achieved mainly within 2 hours after IR, confirmed by the comet momentum in irradiated aMSCs. We also noted that $\gamma-\mathrm{H} 2 \mathrm{AX}$ level in irradiated aMSCs started to decline after 24 hours after IR, as documented in an earlier study [96]. It was shown that these mechanisms are responsible for the radiation resistance in CSC of 4T1 breast cancer cells [101] which highlight their similar function at the biological response of irradiated MSCs from adipose origin. 
In irradiated aMSCs, the up regulated expression of the majority of genes responsible for DNA damage/repair, apoptosis and CC regulation disappeared within 6 hours after IR, which may demonstrate that, most of the IR-induced DNA damage responses have occurred within the first 6 hours after IR. Nevertheless, the level of $\gamma-\mathrm{H} 2 \mathrm{AX}$ was still detectable up to 24 hours after IR at the protein level and started to decline afterwards, which is a trend, that has been documented before in IR biological response of MSCs [96].

Finally, with IR doses up to 8 Gy and duration up to 7 days after IR, our irradiated aMSCs maintained their multi-lineage differentiation potential. A finding that was reported in similar study in irradiated MSCs from bone marrow origin as well (44). Furthermore, irradiated aMSCs retained their phenotype over time after IR, which was mainly evident by the constant expression of surface antigens Sca1, CD29, CD44 and CD105; which are cell surface antigens that have been linked with the resistance to IR in previous studies [92-94].

Although MSCs have been detected and isolated from different tissue sources; e.g. bone marrow, adipose tissue, skin, muscles, umbilical cord, placenta, and kidneys; only MSCs derived from bone marrow were investigated for their radioresistance $[104,106,184]$. Many studies have identified mechanisms that could mediate such radioresistance in bone marrow-derived MSCs. These mechanisms includes: rapid formation of $\gamma-\mathrm{H} 2 \mathrm{AX}$ for robust DSBs repair activation, time efficient G2/M arrest activation, competent DSBs repair, low IR-induced apoptotic response, stimulated expression of DNA damage repair-related genes, significantly high expression of the major player proteins in different IR-induced DNA damage repair pathways including 
HRR, NHEJR and other pathways; namely, DNAPKcs, RAD-51 p-ATM, CHEK2 and others, and activated the anti-oxidant machinery [91, 95, 96, 184, 189]. Even more, one study suggested such radioresistance of bone marrow-derived MSCs in-vivo [190]. Until now, to our knowledge, no studies have investigated the radiosensitivity/resistance of MSCs from adipose tissue origin. Accordingly, our study is considered the first to demonstrate the mechanisms of radioresistance of MSCs derived from adipose tissue.

\subsection{CONCLUSION}

In conclusion, we have shown that MSCs from adipose tissue origin maintain their phenotypical and functional characteristics after exposure to ionizing radiation owing to their possession of a robust, time efficient, and highly coordinating DNA repair machinery. This DNA repair is regulated on both transcriptional and translational levels. The major DNA damage repair pathways, like HR, NHEJ, and p-ATMdependent and p-ATM-independent (p84/5E10-mediated) G2/M arrest, mediate it. Interestingly, G2/M arrest in irradiated aMSCs is not only comparable to that of irradiated mesenchymal-like breast cancer 4T1 cells; that possess a considerable cancer stem cells radio-resistant population; but also might be more superior. These findings show the functional and phenotypical stability of aMSCs after exposure to ionizing radiation. In addition to their source abundance, anti-inflammatory function, easy isolation and high expansion, these findings shall qualify aMSCs to be a reliable cellular therapy option in radiation oncology regenerative medicine therapies before and/or during radiation dose fractionation. Knowing the fact that, clinical trials 
using MSCs to repair or minimize IR-induced normal tissue injury are still lacking, nevertheless, few isolated clinical case reports showed promising beneficial effects of MSCs therapy; e.g. regenerating hematopoiesis and osteoradionecrosis, improved breathing parameters and lung immune function, improved intestinal mucosal inflammation, hemorrhages, fistulization, pain and diarrhea, and regenerated skin ulceration, in ionizing radiation-induced injury of bone, lung, intestine, and skin, respectively $[71,172]$. We hope that our study results help to increase the confidence in adipose-tissue derived MSCs in order to expand their applications in ionizing radiation-induced normal tissue injury therapies.

\section{AKNOWLEDGEMENT}

Osama Muhammad Maria is an awardee of the LDI/TD studentship. This study was supported partially by Ride To Conquer Cancer (RTCC, Jewish General Hospital Foundation) and Fonds de Recherche du Quebec - Santé (FRQS) grants.

\section{DISCLOSURE OF POTENTIAL CONFLICT OF INTEREST}

None. 


\subsection{SUPPLEMENTAL DATA}

\subsubsection{Tables}

\begin{tabular}{|r|r|r|r|}
\hline IR dose & \multicolumn{1}{|l|}{ AMSCs } & \multicolumn{1}{|l|}{$4 \mathrm{T1}$} & \multicolumn{1}{|c|}{ NIH3T3-wt } \\
\hline 0 Gy & $86 \%$ & $86 \%$ & $33 \%$ \\
\hline 2 Gy & $50.5 \%$ & $65 \%$ & $22 \%$ \\
\hline 4 Gy & $34 \%$ & $31 \%$ & $8.3 \%$ \\
\hline 6 Gy & $23.3 \%$ & $10.7 \%$ & $3 \%$ \\
\hline 8 Gy & $11.9 \%$ & $2.8 \%$ & $0.9 \%$ \\
\hline
\end{tabular}

Table.4.8.1.1: Plating efficiency (PE) for all IR doses

\begin{tabular}{|c|c|c|c|c|}
\hline $\begin{array}{c}\text { Gene } \\
\text { Category }\end{array}$ & $\begin{array}{c}\text { aMSCs } 6 \\
\text { hours }\end{array}$ & $\begin{array}{c}\text { aMSCs } 2 \\
\text { hours }\end{array}$ & 4T1 2 hours & $\begin{array}{c}\text { NIH3T3-wt } 2 \\
\text { hours }\end{array}$ \\
\hline $\begin{array}{l}\text { ATM/ATR } \\
\text { Signaling }\end{array}$ & $\begin{array}{l}\text { ATM, ATR, } \\
\text { BRCA1, } \\
\text { BARD1, } \\
\text { CDC25A, } \\
\text { CHEK1, } \\
\text { CHEK2 } \\
\text { (RAD53), } \\
\text { FANCD2, } \\
\text { H2AFX, } \\
\text { HUS1, } \\
\text { MDC1, } \\
\text { PARP1 } \\
\text { (ADPRT1), } \\
\text { PARP2, } \\
\text { RAD1, } \\
\text { RAD17, } \\
\text { RAD50, } \\
\text { RAD9A, } \\
\text { RNF8, } \\
\text { SMC1a, } \\
\text { TOPBP1, } \\
\text { TP53 }\end{array}$ & $\begin{array}{c}\text { ATM, ATR, } \\
\text { BRCA1, } \\
\text { BARD1, } \\
\text { CDC25A, } \\
\text { CHEK1, } \\
\text { CHEK2 } \\
\text { (RAD53), } \\
\text { FANCD2, } \\
\text { H2AFX, HUS1, } \\
\text { MDC1, PARP1 } \\
\text { (ADPRT1), } \\
\text { PARP2, RAD1, } \\
\text { RAD17, } \\
\text { RAD50, } \\
\text { RAD9A, RNF8, } \\
\text { SMC1a, } \\
\text { TOPBP1, TP53 }\end{array}$ & $\begin{array}{c}\text { ATM, ATR, } \\
\text { BRCA1, } \\
\text { BARD1, } \\
\text { CDC25A, } \\
\text { CHEK1, } \\
\text { CHEK2 } \\
\text { (RAD53), } \\
\text { FANCD2, } \\
\text { H2AFX, HUS1, } \\
\text { MDC1, PARP1 } \\
\text { (ADPRT1), } \\
\text { PARP2, RAD1, } \\
\text { RAD17, } \\
\text { RAD50, } \\
\text { RAD9A, RNF8, } \\
\text { SMC1a, } \\
\text { TOPBP1, TP53 }\end{array}$ & $\begin{array}{c}\text { ATM, ATR, } \\
\text { BRCA1, BARD1, } \\
\text { CDC25A, } \\
\text { CHEK1, CHEK2 } \\
\text { (RAD53), } \\
\text { FANCD2, } \\
\text { H2AFX, HUS1, } \\
\text { MDC1, PARP1 } \\
\text { (ADPRT1), } \\
\text { PARP2, RAD1, } \\
\text { RAD17, RAD50, } \\
\text { RAD9A, RNF8, } \\
\text { SMC1a, } \\
\text { TOPBP1, TP53 }\end{array}$ \\
\hline $\begin{array}{l}\text { Nucleotide } \\
\text { Excision } \\
\text { Repair } \\
\text { (NER) }\end{array}$ & $\begin{array}{l}\text { BRCA2, } \\
\text { DDB1, } \\
\text { DDB2, } \\
\text { DCLRE1A, } \\
\text { ERCC1, }\end{array}$ & $\begin{array}{c}\text { BRCA2, DDB1, } \\
\text { DDB2, } \\
\text { DCLRE1A, } \\
\text { ERCC1, } \\
\text { ERCC2 (XPD), }\end{array}$ & $\begin{array}{c}\text { BRCA2, DDB1, } \\
\text { DDB2, } \\
\text { DCLRE1A, } \\
\text { ERCC1, } \\
\text { ERCC2 (XPD), }\end{array}$ & $\begin{array}{c}\text { BRCA2, DDB1, } \\
\text { DDB2, } \\
\text { DCLRE1A, } \\
\text { ERCC1, ERCC2 } \\
\text { (XPD), FANCC, }\end{array}$ \\
\hline
\end{tabular}




\begin{tabular}{|c|c|c|c|c|}
\hline & $\begin{array}{l}\text { ERCC2 } \\
\text { (XPD), } \\
\text { FANCC, } \\
\text { LIG1, } \\
\text { NTHL1, } \\
\text { OGG1, } \\
\text { PCNA, } \\
\text { POLE, } \\
\text { RPA1, TP53, } \\
\text { XPA, XPC }\end{array}$ & $\begin{array}{l}\text { FANCC, LIG1, } \\
\text { NTHL1, OGG1, } \\
\text { PCNA, POLE, } \\
\text { RPA1, TP53, } \\
\text { XPA, XPC }\end{array}$ & $\begin{array}{l}\text { FANCC, LIG1, } \\
\text { NTHL1, OGG1, } \\
\text { PCNA, POLE, } \\
\text { RPA1, TP53, } \\
\text { XPA, XPC }\end{array}$ & $\begin{array}{l}\text { LIG1, NTHL1, } \\
\text { OGG1, PCNA, } \\
\text { POLE, RPA1, } \\
\text { TP53, XPA, XPC }\end{array}$ \\
\hline $\begin{array}{l}\text { Base- } \\
\text { Excision } \\
\text { Repair } \\
\text { (BER) }\end{array}$ & $\begin{array}{c}\text { APEX1, } \\
\text { FEN1, LIG1, } \\
\text { MBD4, } \\
\text { MPG, } \\
\text { NTHL1, } \\
\text { OGG1, } \\
\text { PARP1 } \\
\text { (ADPRT1), } \\
\text { PARP2, } \\
\text { PCNA, } \\
\text { PNKP, } \\
\text { POLE, } \\
\text { TP53, UNG, } \\
\text { XRCC1, } \\
\text { WRN }\end{array}$ & $\begin{array}{l}\text { APEX1, FEN1, } \\
\text { LIG1, MBD4, } \\
\text { MPG, NTHL1, } \\
\text { OGG1, PARP1 } \\
\text { (ADPRT1), } \\
\text { PARP2, PCNA, } \\
\text { PNKP, POLE, } \\
\text { TP53, UNG, } \\
\text { XRCC1, WRN }\end{array}$ & $\begin{array}{l}\text { APEX1, FEN1, } \\
\text { LIG1, MBD4, } \\
\text { MPG, NTHL1, } \\
\text { OGG1, PARP1 } \\
\text { (ADPRT1), } \\
\text { PARP2, PCNA, } \\
\text { PNKP, POLE, } \\
\text { TP53, UNG, } \\
\text { XRCC1, WRN }\end{array}$ & $\begin{array}{l}\text { APEX1, FEN1, } \\
\text { LIG1, MBD4, } \\
\text { MPG, NTHL1, } \\
\text { OGG1, PARP1 } \\
\text { (ADPRT1), } \\
\text { PARP2, PCNA, } \\
\text { PNKP, POLE, } \\
\text { TP53, UNG, } \\
\text { XRCC1, WRN }\end{array}$ \\
\hline $\begin{array}{l}\text { Mismatch } \\
\text { Repair } \\
\text { (MMR) }\end{array}$ & $\begin{array}{l}\text { ABL1, } \\
\text { EXO1, } \\
\text { MBD4, } \\
\text { MLH1, } \\
\text { MLH3, } \\
\text { MSH2, } \\
\text { MSH3, } \\
\text { PCNA, } \\
\text { PMS1, } \\
\text { PMS2 }\end{array}$ & $\begin{array}{l}\text { ABL1, EXO1, } \\
\text { MBD4, MLH1, } \\
\text { MLH3, MSH2, } \\
\text { MSH3, PCNA } \\
\text {,PMS1, PMS2 }\end{array}$ & $\begin{array}{l}\text { ABL1, EXO1, } \\
\text { MBD4, MLH1, } \\
\text { MLH3, MSH2, } \\
\text { MSH3, PCNA } \\
\text {,PMS1, PMS2 }\end{array}$ & $\begin{array}{l}\text { ABL1, EXO1, } \\
\text { MBD4, MLH1, } \\
\text { MLH3, MSH2, } \\
\text { MSH3, PCNA } \\
\text {,PMS1, PMS2 }\end{array}$ \\
\hline $\begin{array}{c}\text { Double } \\
\text { DNA } \\
\text { Strand } \\
\text { Break } \\
\text { Repair } \\
\text { (dsDNAR) }\end{array}$ & $\begin{array}{l}\text { ATM, ATR, } \\
\text { BLM, } \\
\text { BRCA1, } \\
\text { BARD1, } \\
\text { BRCA2, } \\
\text { CHEK1, } \\
\text { DCLRE1A, } \\
\text { EXO1, } \\
\text { FANCD2, } \\
\text { FEN1, } \\
\text { H2AFX, }\end{array}$ & $\begin{array}{c}\text { ATM, ATR, } \\
\text { BLM, BRCA1, } \\
\text { BARD1, } \\
\text { BRCA2, } \\
\text { CHEK1, } \\
\text { DCLRE1A, } \\
\text { EXO1, } \\
\text { FANCD2, } \\
\text { FEN1, H2AFX, } \\
\text { HUS1, LIG1, } \\
\text { MDC1, MLH1, }\end{array}$ & $\begin{array}{c}\text { ATM, ATR, } \\
\text { BLM, BRCA1, } \\
\text { BARD1, } \\
\text { BRCA2, } \\
\text { CHEK1, } \\
\text { DCLRE1A, } \\
\text { EXO1, } \\
\text { FANCD2, } \\
\text { FEN1, H2AFX, } \\
\text { HUS1, LIG1, } \\
\text { MDC1, MLH1, }\end{array}$ & $\begin{array}{c}\text { ATM, ATR, BLM, } \\
\text { BRCA1, BARD1, } \\
\text { BRCA2, CHEK1, } \\
\text { DCLRE1A, } \\
\text { EXO1, FANCD2, } \\
\text { FEN1, H2AFX, } \\
\text { HUS1, LIG1, } \\
\text { MDC1, MLH1, } \\
\text { MRE11A, NBN } \\
\text { (NBS1), PRKDC, } \\
\text { RAD50, RAD51, }\end{array}$ \\
\hline
\end{tabular}




\begin{tabular}{|c|c|c|c|c|}
\hline & $\begin{array}{c}\text { HUS1, LIG1, } \\
\text { MDC1, } \\
\text { MLH1, } \\
\text { MRE11A, } \\
\text { NBN } \\
\text { (NBS1), } \\
\text { PRKDC, } \\
\text { RAD50, } \\
\text { RAD51, } \\
\text { RAD52, } \\
\text { RNF8, } \\
\text { RPA1, } \\
\text { TP53BP1, } \\
\text { XRCC2, } \\
\text { XRCC3, } \\
\text { XRCC6 } \\
\text { (Ku70, } \\
\text { G22P1) } \\
\end{array}$ & $\begin{array}{l}\text { MRE11A, NBN } \\
\text { (NBS1), } \\
\text { PRKDC, } \\
\text { RAD50, } \\
\text { RAD51, } \\
\text { RAD52, RNF8, } \\
\text { RPA1, } \\
\text { TP53BP1, } \\
\text { XRCC2, } \\
\text { XRCC3, } \\
\text { XRCC6 (Ku70, } \\
\text { G22P1) }\end{array}$ & $\begin{array}{l}\text { MRE11A, NBN } \\
\text { (NBS1), } \\
\text { PRKDC, } \\
\text { RAD50, } \\
\text { RAD51, } \\
\text { RAD52, RNF8, } \\
\text { RPA1, } \\
\text { TP53BP1, } \\
\text { XRCC2, } \\
\text { XRCC3, } \\
\text { XRCC6 (Ku70, } \\
\text { G22P1) }\end{array}$ & $\begin{array}{c}\text { RAD52, RNF8, } \\
\text { RPA1, } \\
\text { TP53BP1, } \\
\text { XRCC2, XRCC3 } \\
\text { XRCC6 (Ku70, } \\
\text { G22P1) }\end{array}$ \\
\hline $\begin{array}{l}\text { HR Repair } \\
\text { (HRR) }\end{array}$ & $\begin{array}{c}\text { ATM, ATR, } \\
\text { BLA, } \\
\text { BRCA1, } \\
\text { BARD1, } \\
\text { BRCA2, } \\
\text { CHEK1, } \\
\text { EXO1, } \\
\text { FANCD2, } \\
\text { H2AFX, } \\
\text { HUS1, LIG1, } \\
\text { MDC1, } \\
\text { MLH1, } \\
\text { MRE11A, } \\
\text { PRKDC, } \\
\text { RAD51, } \\
\text { RAD52, } \\
\text { RNF8, } \\
\text { RPA1, } \\
\text { TP53BP1, } \\
\text { XRCC2, } \\
\text { XRCC3 }\end{array}$ & $\begin{array}{l}\text { ATM, ATR, } \\
\text { BLM, BRCA1, } \\
\text { BARD1, } \\
\text { BRCA2, } \\
\text { CHEK1, EXO1, } \\
\text { FANCD2, } \\
\text { H2AFX, HUS1, } \\
\text { LIG1, MDC1, } \\
\text { MLH1, } \\
\text { MRE11A, } \\
\text { PRKDC, } \\
\text { RAD51, } \\
\text { RAD52, RNF8, } \\
\text { RPA1, } \\
\text { TP53BP1, } \\
\text { XRCC2, } \\
\text { XRCC3 }\end{array}$ & $\begin{array}{l}\text { ATM, ATR, } \\
\text { BLM, BRCA1, } \\
\text { BARD1, } \\
\text { BRCA2, } \\
\text { CHEK1, EXO1, } \\
\text { FANCD2, } \\
\text { H2AFX, HUS1, } \\
\text { LIG1, MDC1, } \\
\text { MLH1, } \\
\text { MRE11A, } \\
\text { PRKDC, } \\
\text { RAD51, } \\
\text { RAD52, RNF8, } \\
\text { RPA1, } \\
\text { TP53BP1, } \\
\text { XRCC2, } \\
\text { XRCC3 }\end{array}$ & $\begin{array}{c}\text { ATM, ATR, BLM, } \\
\text { BRCA1, BARD1, } \\
\text { BRCA2, CHEK1, } \\
\text { EXO1, FANCD2, } \\
\text { H2AFX, HUS1, } \\
\text { LIG1, MDC1, } \\
\text { MLH1, MRE11A, } \\
\text { PRKDC, RAD51, } \\
\text { RAD52, RNF8, } \\
\text { RPA1, } \\
\text { TP53BP1, } \\
\text { XRCC2, XRCC3 }\end{array}$ \\
\hline $\begin{array}{c}\text { NHEJ } \\
\text { Repair } \\
\text { (NHEJR) }\end{array}$ & $\begin{array}{l}\text { ATM, ATR, } \\
\text { DCLRE1A } \\
\text { H2AFX, } \\
\text { FEN1, } \\
\text { MRE11A, } \\
\text { NBN(NBS1), } \\
\text { PRKDC, }\end{array}$ & $\begin{array}{l}\text { ATM, ATR, } \\
\text { DCLRE1A, } \\
\text { H2AFX, FEN1, } \\
\text { MRE11A, } \\
\text { NBN(NBS1), } \\
\text { PRKDC, } \\
\text { RAD50, }\end{array}$ & $\begin{array}{c}\text { ATM, ATR, } \\
\text { DCLRE1A, } \\
\text { H2AFX, FEN1, } \\
\text { MRE11A, } \\
\text { NBN(NBS1), } \\
\text { PRKDC, } \\
\text { RAD50, }\end{array}$ & $\begin{array}{c}\text { ATM, ATR, } \\
\text { DCLRE1A, } \\
\text { H2AFX, FEN1, } \\
\text { MRE11A, } \\
\text { NBN(NBS1), } \\
\text { PRKDC, RAD50, }\end{array}$ \\
\hline
\end{tabular}




\begin{tabular}{|c|c|c|c|c|}
\hline & $\begin{array}{l}\text { RAD50, } \\
\text { XRCC6 } \\
\text { (Ku70, } \\
\text { G22P1) }\end{array}$ & $\begin{array}{c}\text { XRCC6 (Ku70, } \\
\text { G22P1) }\end{array}$ & $\begin{array}{c}\text { XRCC6 (Ku70, } \\
\text { G22P1) }\end{array}$ & $\begin{array}{c}\text { XRCC6 (Ku70, } \\
\text { G22P1) }\end{array}$ \\
\hline $\begin{array}{c}\text { Other DNA } \\
\text { Repair } \\
\text { Genes }\end{array}$ & $\begin{array}{l}\text { ATR, ATRIP, } \\
\text { ATRX, } \\
\text { BRIP1, } \\
\text { CHEK2 } \\
\text { (RAD53), } \\
\text { CIB1, CRY1, } \\
\text { FANCA, } \\
\text { FANCD2, } \\
\text { FANCG, } \\
\text { GADD45A, } \\
\text { GADD45G, } \\
\text { MAPK12, } \\
\text { MGMT } \\
\text { (AGT), MPG, } \\
\text { POLH, } \\
\text { PNKP, POLI, } \\
\text { PTTG1, } \\
\text { RAD1, } \\
\text { RAD17, } \\
\text { RAD18, } \\
\text { RAD21, } \\
\text { RAD51C, } \\
\text { RAD51B, } \\
\text { RAD9A, } \\
\text { RBBP8, } \\
\text { REV1, } \\
\text { RNF8, } \\
\text { SIRT1 } \\
\text {,SMC1a, } \\
\text { SMC3, } \\
\text { SUMO1, } \\
\text { TP53BP1, } \\
\text { TP73, } \\
\text { TOPBP1, } \\
\text { XRCC3 }\end{array}$ & $\begin{array}{l}\text { ATR, ATRIP, } \\
\text { ATRX, BRIP1, } \\
\text { CHEK2 } \\
\text { (RAD53), CIB1, } \\
\text { CRY1, FANCA, } \\
\text { FANCD2, } \\
\text { FANCG, } \\
\text { GADD45A, } \\
\text { GADD45G, } \\
\text { MAPK12, } \\
\text { MGMT (AGT), } \\
\text { MPG, POLH, } \\
\text { PNKP, POLI, } \\
\text { PTTG1,RAD1, } \\
\text { RAD17, } \\
\text { RAD18, } \\
\text { RAD21, } \\
\text { RAD51c, } \\
\text { RAD51b, } \\
\text { RAD9A, } \\
\text { RBBP8, REV1, } \\
\text { RNF8, SMC1a, } \\
\text { SIRT1, SMC3, } \\
\text { SUMO1, } \\
\text { TP53BP1, } \\
\text { TP73, } \\
\text { TOPBP1, } \\
\text { XRCC3 }\end{array}$ & $\begin{array}{l}\text { ATR, ATRIP, } \\
\text { ATRX, BRIP1, } \\
\text { CHEK2 } \\
\text { (RAD53), CIB1, } \\
\text { CRY1, FANCA, } \\
\text { FANCD2, } \\
\text { FANCG, } \\
\text { GADD45A, } \\
\text { GADD45G, } \\
\text { MAPK12, } \\
\text { MGMT (AGT), } \\
\text { MPG, POLH, } \\
\text { PNKP, POLI, } \\
\text { PTTG1,RAD1, } \\
\text { RAD17, } \\
\text { RAD18, } \\
\text { RAD21, } \\
\text { RAD51c, } \\
\text { RAD51b, } \\
\text { RAD9A, } \\
\text { RBBP8, REV1, } \\
\text { RNF8, SMC1a, } \\
\text { SIRT1, SMC3, } \\
\text { SUMO1, } \\
\text { TP53BP1, } \\
\text { TP73, } \\
\text { TOPBP1, } \\
\text { XRCC3 }\end{array}$ & $\begin{array}{c}\text { ATR, ATRIP, } \\
\text { ATRX, BRIP1, } \\
\text { CHEK2 } \\
\text { (RAD53), CIB1, } \\
\text { CRY1, FANCA, } \\
\text { FANCD2, } \\
\text { FANCG, } \\
\text { GADD45A, } \\
\text { GADD45G, } \\
\text { MAPK12, MGMT } \\
\text { (AGT), MPG, } \\
\text { POLH, PNKP, } \\
\text { POLI, } \\
\text { PTTG1,RAD1, } \\
\text { RAD17, RAD18, } \\
\text { RAD21, } \\
\text { RAD51C, } \\
\text { RAD51b, } \\
\text { RAD9A, RBBP8, } \\
\text { REV1, RNF8, } \\
\text { SMC1a, SIRT1, } \\
\text { SMC3, SUMO1, } \\
\text { TP53BP1, TP73, } \\
\text { TOPBP1, } \\
\text { XRCC3 }\end{array}$ \\
\hline Apoptosis & $\begin{array}{c}\text { ABL1, ATM, } \\
\text { BAX, BBC3, } \\
\text { BRCA1, } \\
\text { BARD1, } \\
\text { CDKN1A } \\
\text { (P21CIP1/W } \\
\text { AF1), }\end{array}$ & $\begin{array}{c}\text { ABL1, ATM, } \\
\text { BAX, BBC3, } \\
\text { BRCA1, } \\
\text { BARD1, } \\
\text { CDKN1A } \\
\text { (P21CIP1/WAF } \\
\text { 1), CHEK2 }\end{array}$ & $\begin{array}{c}\text { ABL1, ATM, } \\
\text { BAX, BBC3, } \\
\text { BRCA1, } \\
\text { BARD1, } \\
\text { CDKN1A } \\
\text { (P21CIP1/WAF } \\
\text { 1), CHEK2 }\end{array}$ & $\begin{array}{c}\text { ABL1, ATM, } \\
\text { BAX, BBC3, } \\
\text { BRCA1, BARD1, } \\
\text { CDKN1A } \\
\text { (P21CIP1/WAF1) } \\
\text {, CHEK2 } \\
\text { (RAD53), }\end{array}$ \\
\hline
\end{tabular}




\begin{tabular}{|c|c|c|c|c|}
\hline & $\begin{array}{c}\text { CHEK2 } \\
\text { (RAD53), } \\
\text { PPP1R15A } \\
\text { (GADD34), } \\
\text { PRKDC, } \\
\text { RAD21, } \\
\text { RAD9A, } \\
\text { TERF1, } \\
\text { TP53BP1,TP } \\
53 \text { (TRP53), } \\
\text { TP73 }\end{array}$ & $\begin{array}{c}\text { (RAD53), } \\
\text { PPP1R15A } \\
\text { (GADD34), } \\
\text { PRKDC, } \\
\text { RAD21, } \\
\text { RAD9A, } \\
\text { TERF1, } \\
\text { TP53BP1,TP53 } \\
\text {, TP73 }\end{array}$ & $\begin{array}{c}\text { (RAD53), } \\
\text { PPP1R15A } \\
\text { (GADD34), } \\
\text { PRKDC, } \\
\text { RAD21, } \\
\text { RAD9A, } \\
\text { TERF1, } \\
\text { TP53BP1,TP53 } \\
\text {, TP73 }\end{array}$ & $\begin{array}{c}\text { PPP1R15A } \\
\text { (GADD34), } \\
\text { PRKDC, RAD21, } \\
\text { RAD9A, } \\
\text { TERF1, } \\
\text { TP53BP1, TP53, } \\
\text { TP73 }\end{array}$ \\
\hline $\begin{array}{l}\text { Cell Cycle } \\
\text { (CC) }\end{array}$ & $\begin{array}{c}\text { ABL1, ATM, } \\
\text { ATR, } \\
\text { BRCA1, } \\
\text { BRCA2 } \\
\text { CDC25A, } \\
\text { CDC25C, } \\
\text { CDKN1A } \\
\text { (P21CIP1/W } \\
\text { AF1), } \\
\text { CHEK1, } \\
\text { CHEK2 } \\
\text { (RAD53), } \\
\text { CSNK2A2, } \\
\text { DDIT3 } \\
\text { (GADD153/ } \\
\text { CHOP), } \\
\text { GADD45A, } \\
\text { HUS1, } \\
\text { MRE11A, } \\
\text { MSH2, } \\
\text { MAPK12, } \\
\text { MCPH1, } \\
\text { MDC1, MIF, } \\
\text { NBN } \\
\text { (NBS1), } \\
\text { PPM1D, } \\
\text { PPP1R15A } \\
\text { (GADD34), } \\
\text { RAD9A, } \\
\text { RAD17, } \\
\text { RAD51, } \\
\text { RBBP8, } \\
\text { TERF1, } \\
\text { TP53BP1, }\end{array}$ & $\begin{array}{c}\text { ABL1, ATM, } \\
\text { ATR, BRCA1, } \\
\text { BRCA2, } \\
\text { CDC25A, } \\
\text { CDC25C, } \\
\text { CDKN1A } \\
\text { (P21CIP1/WAF } \\
\text { 1), CHEK1, } \\
\text { CHEK2 } \\
\text { (RAD53), } \\
\text { CSNK2A2, } \\
\text { DDIT3 } \\
\text { (GADD153/CH } \\
\text { OP), } \\
\text { GADD45A, } \\
\text { HUS1, } \\
\text { MRE11A, } \\
\text { MSH2, } \\
\text { MAPK12, } \\
\text { MCPH1, } \\
\text { MDC1, MIF, } \\
\text { NBN (NBS1), } \\
\text { PPM1D, } \\
\text { PPP1R15A } \\
\text { (GADD34), } \\
\text { RAD9A, } \\
\text { RAD17, } \\
\text { RAD51, } \\
\text { RBBP8, } \\
\text { TERF1, } \\
\text { TP53BP1, } \\
\text { TP53 (TRP53) }\end{array}$ & $\begin{array}{c}\text { ABL1, ATM, } \\
\text { ATR, BRCA1, } \\
\text { BRCA2, } \\
\text { CDC25A, } \\
\text { CDC25C, } \\
\text { CDKN1A } \\
\text { (P21CIP1/WAF } \\
\text { 1), CHEK1, } \\
\text { CHEK2 } \\
\text { (RAD53), } \\
\text { CSNK2A2, } \\
\text { DDIT3 } \\
\text { (GADD153/CH } \\
\text { OP), } \\
\text { GADD45A, } \\
\text { HUS1, } \\
\text { MRE11A, } \\
\text { MSH2, } \\
\text { MAPK12, } \\
\text { MCPH1, } \\
\text { MDC1, MIF, } \\
\text { NBN (NBS1), } \\
\text { PPM1D, } \\
\text { PPP1R15A } \\
\text { (GADD34), } \\
\text { RAD9A, } \\
\text { RAD17, } \\
\text { RAD51, } \\
\text { RBBP8, } \\
\text { TERF1, } \\
\text { TP53BP1, } \\
\text { TP53 (TRP53) }\end{array}$ & $\begin{array}{c}\text { ABL1, ATM, } \\
\text { ATR, BRCA1, } \\
\text { BRCA2, } \\
\text { CDC25A, } \\
\text { CDC25C, } \\
\text { CDKN1A } \\
\text { (P21CIP1/WAF1) } \\
\text {, CHEK1, } \\
\text { CHEK2 } \\
\text { (RAD53), } \\
\text { CSNK2A2, } \\
\text { DDIT3 } \\
\text { (GADD153/CHO } \\
\text { P), GADD45A, } \\
\text { HUS1, MRE11A, } \\
\text { MSH2, MAPK12, } \\
\text { MCPH1, MDC1, } \\
\text { MIF, NBN } \\
\text { (NBS1), PPM1D, } \\
\text { PPP1R15A } \\
\text { (GADD34), } \\
\text { RAD9A, RAD17, } \\
\text { RAD51, RBBP8, } \\
\text { TERF1, } \\
\text { TP53BP1, TP53 } \\
\text { (TRP53) }\end{array}$ \\
\hline
\end{tabular}




\begin{tabular}{|c|c|c|c|c|}
\hline & $\begin{array}{c}\text { TP53 } \\
\text { (TRP53) }\end{array}$ & & & \\
\hline $\begin{array}{l}\text { S-Phase / } \\
\text { DNA } \\
\text { replication }\end{array}$ & $\begin{array}{l}\text { MRE11A, } \\
\text { MSH2, } \\
\text { RAD17, } \\
\text { RAD51 }\end{array}$ & $\begin{array}{c}\text { MRE11A, } \\
\text { MSH2, RAD17, } \\
\text { RAD51 }\end{array}$ & $\begin{array}{c}\text { MRE11A, } \\
\text { MSH2, RAD17, } \\
\text { RAD51 }\end{array}$ & $\begin{array}{l}\text { MRE11A, MSH2, } \\
\text { RAD17, RAD51 }\end{array}$ \\
\hline $\begin{array}{c}\mathrm{G} 2 / \mathrm{M} \\
\text { Transition }\end{array}$ & $\begin{array}{l}\text { CHECK1, } \\
\text { PPM1D }\end{array}$ & $\begin{array}{l}\text { CHEK1, } \\
\text { PPM1D }\end{array}$ & $\begin{array}{l}\text { CHEK1, } \\
\text { PPM1D }\end{array}$ & CHEK1, PPM1D \\
\hline $\begin{array}{l}\text { Cell Cycle } \\
\text { checkpoint } \\
\text { / Arrest }\end{array}$ & $\begin{array}{c}\text { ATR, } \\
\text { BRCA1, } \\
\text { CDC25C, } \\
\text { CDKN1A } \\
\text { (P21CIP1/W } \\
\text { AF1), } \\
\text { CHECK1, } \\
\text { DDIT3, } \\
\text { GAD45A, } \\
\text { HUS1, } \\
\text { MSH2, NBN } \\
\text { (NBS1), } \\
\text { PPM1D, } \\
\text { RAD9A }\end{array}$ & $\begin{array}{c}\text { ATR, BRCA1, } \\
\text { CDC25C, } \\
\text { CDKN1A } \\
\text { (P21CIP1/WAF } \\
\text { 1), CHEK1, } \\
\text { DDIT3, } \\
\text { GADD45A, } \\
\text { HUS1, MSH2, } \\
\text { NBN (NBS1), } \\
\text { PPM1D, } \\
\text { RAD9A }\end{array}$ & $\begin{array}{c}\text { ATR, BRCA1, } \\
\text { CDC25C, } \\
\text { CDKN1A } \\
\text { (P21CIP1/WAF } \\
\text { 1), CHEK1, } \\
\text { DDIT3, } \\
\text { GADD45A, } \\
\text { HUS1, MSH2, } \\
\text { NBN (NBS1), } \\
\text { PPM1D, } \\
\text { RAD9A }\end{array}$ & $\begin{array}{c}\text { ATR, BRCA1, } \\
\text { CDC25C, } \\
\text { CDKN1A } \\
\text { (P21CIP1/WAF1) } \\
\text {, CHEK1, DDIT3, } \\
\text { GADD45A, } \\
\text { HUS1, MSH2, } \\
\text { NBN (NBS1), } \\
\text { PPM1D, RAD9A }\end{array}$ \\
\hline $\begin{array}{l}\text { Cell Cycle } \\
\text { Regulators }\end{array}$ & $\begin{array}{l}\text { ABL1, ATR, } \\
\text { BRCA2, } \\
\text { CDC25C, } \\
\text { CDKN1A } \\
\text { (P21CIP1/W } \\
\text { AF1), } \\
\text { GADD45A, } \\
\text { RAD9A }\end{array}$ & $\begin{array}{c}\text { ABL1, ATR, } \\
\text { BRCA2, } \\
\text { CDC25C, } \\
\text { CDKN1A } \\
\text { (P21CIP1/WAF } \\
\text { 1), GADD45A, } \\
\text { RAD9A }\end{array}$ & $\begin{array}{c}\text { ABL1, ATR, } \\
\text { BRCA2, } \\
\text { CDC25C, } \\
\text { CDKN1A } \\
\text { (P21CIP1/WAF } \\
\text { 1), GADD45A, } \\
\text { RAD9A }\end{array}$ & $\begin{array}{c}\text { ABL1, ATR, } \\
\text { BRCA2, } \\
\text { CDC25C, } \\
\text { CDKN1A } \\
\text { (P21CIP1/WAF1) } \\
\text {, GADD45A, } \\
\text { RAD9A }\end{array}$ \\
\hline $\begin{array}{l}\text { Negative } \\
\text { Cell Cycle } \\
\text { Regulators }\end{array}$ & $\begin{array}{c}\text { ATM, } \\
\text { BRCA1, } \\
\text { TP53 } \\
\text { (TRP53) } \\
\end{array}$ & $\begin{array}{l}\text { ATM, BRCA1, } \\
\text { TP53 (TRP53) }\end{array}$ & $\begin{array}{l}\text { ATM, BRCA1, } \\
\text { TP53 (TRP53) }\end{array}$ & $\begin{array}{l}\text { ATM, BRCA1, } \\
\text { TP53 (TRP53) }\end{array}$ \\
\hline
\end{tabular}


Table.4.8.1.2: Listing the up regulated and down regulated DNA damage/repair related genes with times after irradiation

\begin{tabular}{|c|c|c|c|}
\hline Symbol & Description & Gene Name & Gene Bank \\
\hline$\overline{A B L 1}$ & $\begin{array}{l}\text { C-abl oncogene } 1, \text { non- } \\
\text { receptor tyrosine kinase }\end{array}$ & $\begin{array}{l}\text { Al325092, Abl, } \\
\text { E430008G22Rik, c- } \\
\text { Abl }\end{array}$ & NM_009594 \\
\hline APEX1 & $\begin{array}{l}\text { Apurinic/apyrimidinic } \\
\text { endonuclease } 1\end{array}$ & $\begin{array}{l}\text { APE, Apex, HAP1, } \\
\text { Ref-1 }\end{array}$ & NM_009687 \\
\hline ATM & $\begin{array}{l}\text { Ataxia telangiectasia } \\
\text { mutated homolog } \\
\text { (human) }\end{array}$ & $\begin{array}{l}\text { Al256621, } \\
\text { C030026E19Rik }\end{array}$ & NM_007499 \\
\hline ATR & $\begin{array}{l}\text { Ataxia telangiectasia and } \\
\text { rad3 related }\end{array}$ & - & NM_019864 \\
\hline ATRX & $\begin{array}{l}\text { Alpha thalassemia/mental } \\
\text { retardation syndrome X- } \\
\text { linked homolog (human) }\end{array}$ & $\begin{array}{l}\text { 4833408C14Rik, } \\
\text { Al447451, ATR2, } \\
\text { DXHXS6677E, HP1- } \\
\text { BP38, Hp1bp2, } \\
\text { Hp1bp38, MRkXS3, } \\
\text { RAD54L, Rad54, } \\
\text { XH2, Xnp, ZNF-HX }\end{array}$ & NM_009530 \\
\hline BAX & Bcl2-associated X protein & - & NM_007527 \\
\hline BLM & $\begin{array}{l}\text { Bloom syndrome, RecQ } \\
\text { helicase-like }\end{array}$ & - & NM_007550 \\
\hline BRCA1 & Breast cancer 1 & - & NM_009764 \\
\hline BRCA2 & Breast cancer 2 & Fancd1, RAB163 & NM_009765 \\
\hline BRIP1 & $\begin{array}{l}\text { BRCA1 interacting protein } \\
\text { C-terminal helicase } 1\end{array}$ & $\begin{array}{l}\text { 3110009N10Rik, } \\
\text { 8030460J03Rik, } \\
\text { Bach1, FACJ, Fancj, } \\
\text { OF }\end{array}$ & NM_178309 \\
\hline CDC25A & $\begin{array}{l}\text { Cell division cycle } 25 \\
\text { homolog A (S. pombe) }\end{array}$ & D9Ertd393e & NM_007658 \\
\hline CDC25C & $\begin{array}{l}\text { Cell division cycle } 25 \\
\text { homolog C (S. pombe) }\end{array}$ & Cdc25 & NM_009860 \\
\hline CDKN1A & $\begin{array}{l}\text { Cyclin-dependent kinase } \\
\text { inhibitor } 1 \mathrm{~A}(\mathrm{P} 21)\end{array}$ & $\begin{array}{l}\text { CAP20, CDKI, CIP1, } \\
\text { Cdkn1, P21, SDI1, } \\
\text { Waf1, mda6, p21Cip1, } \\
\text { p21WAF }\end{array}$ & NM_007669 \\
\hline CHEK1 & $\begin{array}{l}\text { Checkpoint kinase } 1 \\
\text { homolog (S. pombe) }\end{array}$ & C85740, Chk1, rad27 & NM_007691 \\
\hline CHEK2 & $\begin{array}{l}\text { CHK2 checkpoint } \\
\text { homolog (S. pombe) }\end{array}$ & $\begin{array}{l}\text { CHK2, Cds1, } \\
\text { HUCDS1, Rad53 }\end{array}$ & NM_016681 \\
\hline
\end{tabular}




\begin{tabular}{|c|c|c|c|}
\hline DCLRE1A & $\begin{array}{l}\text { DNA cross-link repair 1A, } \\
\text { PSO2 homolog (S. } \\
\text { cerevisiae) }\end{array}$ & $\begin{array}{l}\text { 2810043H12Rik, } \\
\text { AU022226, Pso2, } \\
\text { Smn1a, Snm1, } \\
\text { mKIAA0086 }\end{array}$ & NM_018831 \\
\hline DDB2 & $\begin{array}{l}\text { Damage specific DNA } \\
\text { binding protein } 2\end{array}$ & 2610043A19Rik & NM_028119 \\
\hline DDIT3 & $\begin{array}{l}\text { DNA-damage inducible } \\
\text { transcript } 3\end{array}$ & $\begin{array}{l}\text { CHOP-10, CHOP10, } \\
\text { chop, gadd153 }\end{array}$ & NM_007837 \\
\hline ERCC1 & $\begin{array}{l}\text { Excision repair cross- } \\
\text { complementing rodent } \\
\text { repair deficiency, } \\
\text { complementation group } 1\end{array}$ & Ercc-1 & NM_007948 \\
\hline ERCC2 & $\begin{array}{l}\text { Excision repair cross- } \\
\text { complementing rodent } \\
\text { repair deficiency, } \\
\text { complementation group } 2\end{array}$ & $\begin{array}{l}\text { AA407812, } \\
\text { AU020867, } \\
\text { AW240756, CXPD, } \\
\text { Ercc-2, XPD }\end{array}$ & NM_007949 \\
\hline EXO1 & Exonuclease 1 & 5730442G03Rik, Msa & NM_012012 \\
\hline FANCA & $\begin{array}{l}\text { Fanconi anemia, } \\
\text { complementation group A }\end{array}$ & AW208693, FACA & NM_016925 \\
\hline FANCC & $\begin{array}{l}\text { Fanconi anemia, } \\
\text { complementation group C }\end{array}$ & Facc & NM_007985 \\
\hline FANCD2 & $\begin{array}{l}\text { Fanconi anemia, } \\
\text { complementation group } \\
\text { D2 }\end{array}$ & $\begin{array}{l}\text { 2410150O07Rik, } \\
\text { AU015151, } \\
\text { BB137857, FA-D2, } \\
\text { FA4, FACD, FAD, } \\
\text { FANCD }\end{array}$ & NM_001033244 \\
\hline FANCG & $\begin{array}{l}\text { Fanconi anemia, } \\
\text { complementation group G }\end{array}$ & AU041407, Xrcc9 & NM_053081 \\
\hline FEN1 & $\begin{array}{l}\text { Flap structure specific } \\
\text { endonuclease } 1\end{array}$ & AW538437, FEN-1 & NM_007999 \\
\hline GADD45A & $\begin{array}{l}\text { Growth arrest and DNA- } \\
\text { damage-inducible } 45 \\
\text { alpha }\end{array}$ & $\begin{array}{l}\text { AA545191, Ddit1, } \\
\text { GADD45 }\end{array}$ & NM_007836 \\
\hline GADD45G & $\begin{array}{l}\text { Growth arrest and DNA- } \\
\text { damage-inducible } 45 \\
\text { gamma }\end{array}$ & $\begin{array}{l}\text { Al327420, C86281, } \\
\text { CR6, DDIT2, OIG37 }\end{array}$ & NM_011817 \\
\hline H2AFX & $\begin{array}{l}\text { H2A histone family, } \\
\text { member } X\end{array}$ & $\begin{array}{l}\text { AW228881, H2A.X, } \\
\text { H2ax, Hist5-2ax, } \\
\text { gamma-H2ax }\end{array}$ & NM_010436 \\
\hline HUS1 & $\begin{array}{l}\text { Hus1 homolog (S. } \\
\text { pombe) }\end{array}$ & mHus1 & NM_008316 \\
\hline LIG1 & $\begin{array}{l}\text { Ligase I, DNA, ATP- } \\
\text { dependent }\end{array}$ & AL033288, Ligl & NM_010715 \\
\hline MBD4 & $\begin{array}{l}\text { Methyl-CpG binding } \\
\text { domain protein } 4\end{array}$ & Med1 & NM_010774 \\
\hline
\end{tabular}




\begin{tabular}{|c|c|c|c|}
\hline $\mathrm{MCPH} 1$ & $\begin{array}{l}\text { Microcephaly, primary } \\
\text { autosomal recessive } 1\end{array}$ & $\begin{array}{l}\text { 5430437K10Rik, } \\
\text { BRIT1, } \\
\text { D030046N04Rik, } \\
\text { MCT }\end{array}$ & NM_173189 \\
\hline MDC1 & $\begin{array}{l}\text { Mediator of DNA damage } \\
\text { checkpoint } 1\end{array}$ & $\begin{array}{l}\text { 6820401C03, } \\
\text { AA413496, Nfbd1, } \\
\text { mKIAA0170 }\end{array}$ & NM_001010833 \\
\hline MGMT & $\begin{array}{l}\text { O-6-methylguanine-DNA } \\
\text { methyltransferase }\end{array}$ & AGT, Al267024, Agat & NM_008598 \\
\hline $\mathrm{MIF}$ & $\begin{array}{l}\text { Macrophage migration } \\
\text { inhibitory factor }\end{array}$ & GIF, Glif & NM_010798 \\
\hline MLH1 & MutL homolog 1 (E. coli) & $\begin{array}{l}\text { 1110035C23Rik, } \\
\text { Al317206, Al325952, } \\
\text { Al561766 }\end{array}$ & NM_026810 \\
\hline MLH3 & MutL homolog 3 (E coli) & AV125803, BB126472 & NM_175337 \\
\hline MPG & $\begin{array}{l}\text { N-methylpurine-DNA } \\
\text { glycosylase }\end{array}$ & $\begin{array}{l}\text { 9830006D05, } \\
\text { Al326268, APNG, } \\
\text { Aag, Mid1 }\end{array}$ & NM_010822 \\
\hline MRE11A & $\begin{array}{l}\text { Meiotic recombination } 11 \\
\text { homolog A (S. cerevisiae) }\end{array}$ & Mre11, Mre11b & NM_018736 \\
\hline MSH2 & MutS homolog 2 (E. coli) & Al788990 & NM_008628 \\
\hline MSH3 & MutS homolog 3 (E. coli) & $\begin{array}{l}\text { D13Em1, Rep-3, } \\
\text { Rep3 }\end{array}$ & NM_010829 \\
\hline NBN & Nibrin & Nbs1 & NM_013752 \\
\hline NTHL1 & $\begin{array}{l}\text { Nth (endonuclease III)- } \\
\text { like } 1 \text { (E.coli) }\end{array}$ & Nth1, Octs3 & NM_008743 \\
\hline OGG1 & $\begin{array}{l}\text { 8-oxoguanine DNA- } \\
\text { glycosylase } 1\end{array}$ & $\mathrm{Mmh}$ & NM_010957 \\
\hline PARP1 & $\begin{array}{l}\text { Poly (ADP-ribose) } \\
\text { polymerase family, } \\
\text { member } 1\end{array}$ & $\begin{array}{l}\text { 5830444G22Rik, } \\
\text { Al893648, ARTD1, } \\
\text { Adprp, Adprt1, } \\
\text { C80510, PARP, } \\
\text { PPOL, parp-1, } \\
\text { sPARP-1 }\end{array}$ & NM_007415 \\
\hline PARP2 & $\begin{array}{l}\text { Poly (ADP-ribose) } \\
\text { polymerase family, } \\
\text { member } 2\end{array}$ & $\begin{array}{l}\text { ARTD2, Adprt2, } \\
\text { Adprt12, Aspartl2, } \\
\text { C78626, PARP-2 }\end{array}$ & NM_009632 \\
\hline PCNA & $\begin{array}{l}\text { Proliferating cell nuclear } \\
\text { antigen }\end{array}$ & - & NM_011045 \\
\hline PMS2 & $\begin{array}{l}\text { Postmeiotic segregation } \\
\text { increased } 2 \text { (S. } \\
\text { cerevisiae) }\end{array}$ & AW555130, Pmsl2 & NM_008886 \\
\hline POLE & $\begin{array}{l}\text { Polymerase (DNA } \\
\text { directed), epsilon }\end{array}$ & - & NM_011132 \\
\hline
\end{tabular}




\begin{tabular}{|c|c|c|c|}
\hline POLH & $\begin{array}{l}\text { Polymerase (DNA } \\
\text { directed), eta (RAD } 30 \\
\text { related) }\end{array}$ & RAD30A, XPV & NM_030715 \\
\hline POLI & $\begin{array}{l}\text { Polymerase (DNA } \\
\text { directed), iota }\end{array}$ & Rad30b & NM_011972 \\
\hline PPM1D & $\begin{array}{l}\text { Protein phosphatase 1D } \\
\text { magnesium-dependent, } \\
\text { delta isoform }\end{array}$ & AV338790, Wip1 & NM_016910 \\
\hline PPP1R15A & $\begin{array}{l}\text { Protein phosphatase 1, } \\
\text { regulatory (inhibitor) } \\
\text { subunit } 15 A\end{array}$ & $\begin{array}{l}\text { 9630030H21, } \\
\text { Gadd34, Myd116 }\end{array}$ & NM_008654 \\
\hline PRKDC & $\begin{array}{l}\text { Protein kinase, DNA } \\
\text { activated, catalytic } \\
\text { polypeptide }\end{array}$ & $\begin{array}{l}\text { Al326420, AU019811, } \\
\text { DNA-PKcs, } \\
\text { DNAPDcs, DNAPK, } \\
\text { DNPK1, DOXNPH, } \\
\text { HYRC1, XRCC7, } \\
\text { dxnph, p460, scid, slip }\end{array}$ & NM_011159 \\
\hline PTTG1 & $\begin{array}{l}\text { Pituitary tumor- } \\
\text { transforming gene } 1\end{array}$ & $\begin{array}{l}\text { AW555095, C87862, } \\
\text { Pttg, Pttg3 }\end{array}$ & NM_013917 \\
\hline RAD1 & $\begin{array}{l}\text { RAD1 homolog (S. } \\
\text { pombe) }\end{array}$ & - & NM_011232 \\
\hline RAD17 & $\begin{array}{l}\text { RAD17 homolog (S. } \\
\text { pombe) }\end{array}$ & MmRad24 & NM_011233 \\
\hline RAD18 & $\begin{array}{l}\text { RAD18 homolog (S. } \\
\text { cerevisiae) }\end{array}$ & $\begin{array}{l}\text { 2810024C04Rik, } \\
\text { Rad18sc }\end{array}$ & NM_021385 \\
\hline RAD21 & $\begin{array}{l}\text { RAD21 homolog (S. } \\
\text { pombe) }\end{array}$ & SCC1, mKIAA0078 & NM_009009 \\
\hline RAD50 & $\begin{array}{l}\text { RAD50 homolog (S. } \\
\text { cerevisiae) }\end{array}$ & Mrell, Rad50l & NM_009012 \\
\hline RAD51 & $\begin{array}{l}\text { RAD51 homolog (S. } \\
\text { cerevisiae) }\end{array}$ & $\begin{array}{l}\text { AV304093, Rad51a, } \\
\text { Reca }\end{array}$ & NM_011234 \\
\hline RAD51C & $\begin{array}{l}\text { Rad51 homolog c (S. } \\
\text { cerevisiae) }\end{array}$ & R51H3, Rad51l2 & NM_053269 \\
\hline RAD51B & $\begin{array}{l}\text { RAD51-like } 1 \text { (S. } \\
\text { cerevisiae) }\end{array}$ & $\begin{array}{l}\text { Al553500, R51H2, } \\
\text { Rad5111, mREC2 }\end{array}$ & NM_009014 \\
\hline RAD52 & $\begin{array}{l}\text { RAD52 homolog (S. } \\
\text { cerevisiae) }\end{array}$ & Rad52yh & NM_011236 \\
\hline RAD9A & $\begin{array}{l}\text { RAD9 homolog (S. } \\
\text { pombe) }\end{array}$ & Rad9 & NM_011237 \\
\hline REV1 & $\begin{array}{l}\text { REV1 homolog (S. } \\
\text { cerevisiae) }\end{array}$ & $\begin{array}{l}\text { 1110027l23Rik, } \\
\text { AU022044, Rev1I }\end{array}$ & NM_019570 \\
\hline RNF8 & Ring finger protein 8 & $\begin{array}{l}\text { 3830404E21Rik, } \\
\text { AIP37 }\end{array}$ & NM_021419 \\
\hline RPA1 & Replication protein A1 & $\begin{array}{l}\text { 5031405K23Rik, } \\
\text { 70kDa, AA589576, }\end{array}$ & NM_026653 \\
\hline
\end{tabular}




\begin{tabular}{|c|c|c|c|}
\hline & & $\begin{array}{l}\text { AW557552, RF-A, } \\
\text { RP-A, Rpa }\end{array}$ & \\
\hline SMC1A & $\begin{array}{l}\text { Structural maintenance of } \\
\text { chromosomes } 1 \mathrm{~A}\end{array}$ & $\begin{array}{l}\text { 5830426I24Rik, SMC- } \\
\text { 1A, Sb1.8, Smc1, } \\
\text { Smc1alpha, Smc1l1, } \\
\text { Smcb, mKIAA0178 }\end{array}$ & NM_019710 \\
\hline SMC3 & $\begin{array}{l}\text { Structural maintenace of } \\
\text { chromosomes } 3\end{array}$ & $\begin{array}{l}\text { Bamacan, Cspg6, } \\
\text { HCAP, Mmip1, SMC- } \\
\text { 3, SmcD }\end{array}$ & NM_007790 \\
\hline SUMO1 & $\begin{array}{l}\text { SMT3 suppressor of mif } \\
\text { two } 3 \text { homolog } 1 \text { (yeast) }\end{array}$ & $\begin{array}{l}\text { GMP1, PIC1, } \\
\text { SENTRIN, SMT3, } \\
\text { SMT3H3, SMTP3, } \\
\text { SUMO-1, Smt3C, } \\
\text { Ubl1 }\end{array}$ & NM_009460 \\
\hline TERF1 & $\begin{array}{l}\text { Telomeric repeat binding } \\
\text { factor } 1\end{array}$ & Pin2, Trbf1, Trf1 & NM_009352 \\
\hline TOPBP1 & $\begin{array}{l}\text { Topoisomerase (DNA) II } \\
\text { binding protein } 1\end{array}$ & $\begin{array}{l}\text { 1110031N14Rik, } \\
\text { 2810429C13Rik, } \\
\text { Al256758, } \\
\text { D430026L04Rik, } \\
\text { mKIAA0259 }\end{array}$ & NM_176979 \\
\hline TRP53 & $\begin{array}{l}\text { Transformation related } \\
\text { protein } 53\end{array}$ & $\begin{array}{l}\text { Tp53, bbl, bfy, bhy, } \\
\text { p44, p53 }\end{array}$ & NM_011640 \\
\hline TRP53BP1 & $\begin{array}{l}\text { Transformation related } \\
\text { protein } 53 \text { binding protein } \\
1\end{array}$ & $\begin{array}{l}\text { 53BP1, Tp53bp1, } \\
\text { m53BP1 }\end{array}$ & NM_013735 \\
\hline UNG & Uracil DNA glycosylase & UNG1, UNG2 & NM_011677 \\
\hline WRN & $\begin{array}{l}\text { Werner syndrome } \\
\text { homolog (human) }\end{array}$ & Al846146 & NM_011721 \\
\hline$\overline{\mathrm{XPA}}$ & $\begin{array}{l}\text { Xeroderma pigmentosum, } \\
\text { complementation group } \mathrm{A}\end{array}$ & Al573865, Хpac & NM_011728 \\
\hline XPC & $\begin{array}{l}\text { Xeroderma pigmentosum, } \\
\text { complementation group C }\end{array}$ & - & NM_009531 \\
\hline XRCC1 & $\begin{array}{l}\text { X-ray repair } \\
\text { complementing defective } \\
\text { repair in Chinese hamster } \\
\text { cells } 1\end{array}$ & Xrcc-1 & NM_009532 \\
\hline XRCC2 & $\begin{array}{l}\text { X-ray repair } \\
\text { complementing defective } \\
\text { repair in Chinese hamster } \\
\text { cells } 2\end{array}$ & $\begin{array}{l}\text { 4921524O04Rik, } \\
\text { 8030409M04Rik, } \\
\text { RAD51, RecA }\end{array}$ & NM_020570 \\
\hline XRCC3 & $\begin{array}{l}\text { X-ray repair } \\
\text { complementing defective } \\
\text { repair in Chinese hamster } \\
\text { cells } 3\end{array}$ & $\begin{array}{l}\text { 4432412E01Rik, } \\
\text { Al182522, AW537713 }\end{array}$ & NM_028875 \\
\hline
\end{tabular}




\begin{tabular}{|c|c|c|c|}
\hline XRCC6 & $\begin{array}{l}\text { X-ray repair } \\
\text { complementing defective } \\
\text { repair in Chinese hamster } \\
\text { cells } 6\end{array}$ & 70kDa, G22p1, Ku70 & NM_010247 \\
\hline ACTB & Actin, beta & $\begin{array}{l}\text { Actx, } \\
\text { E430023M04Rik, } \\
\text { beta-actin }\end{array}$ & NM_007393 \\
\hline B2M & Beta-2 microglobulin & $\begin{array}{l}\text { Ly-m11, beta2-m, } \\
\text { beta2m }\end{array}$ & NM_009735 \\
\hline GAPDH & $\begin{array}{l}\text { Glyceraldehyde-3- } \\
\text { phosphate } \\
\text { dehydrogenase }\end{array}$ & Gapd & NM_008084 \\
\hline GUSB & Glucuronidase, beta & $\begin{array}{l}\text { Al747421, Gur, Gus, } \\
\text { Gus-r, Gus-s, Gus-t, } \\
\text { Gus-u, Gut, asd, g }\end{array}$ & NM_010368 \\
\hline HSP90AB1 & $\begin{array}{l}\text { Heat shock protein } 90 \\
\text { alpha (cytosolic), class B } \\
\text { member } 1\end{array}$ & $\begin{array}{l}\text { 90kDa, AL022974, } \\
\text { C81438, Hsp84, } \\
\text { Hsp84-1, Hsp90, } \\
\text { Hspcb }\end{array}$ & NM_008302 \\
\hline
\end{tabular}

Table.4.8.1.3: List of all tested genes 


\subsubsection{Supplemental figures}

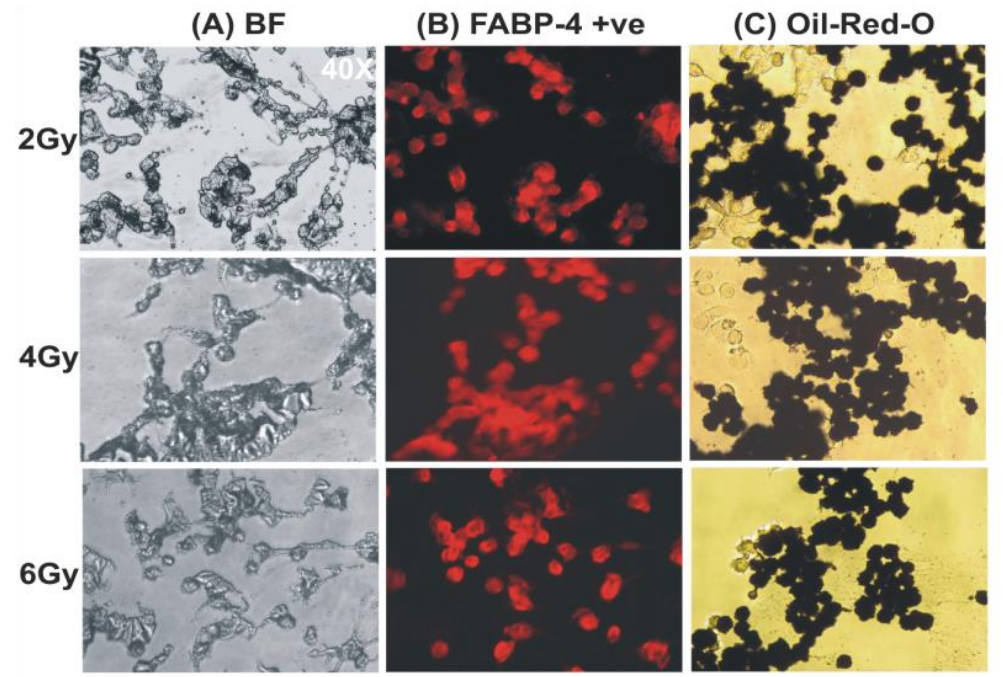

(D) $\mathrm{BF}$

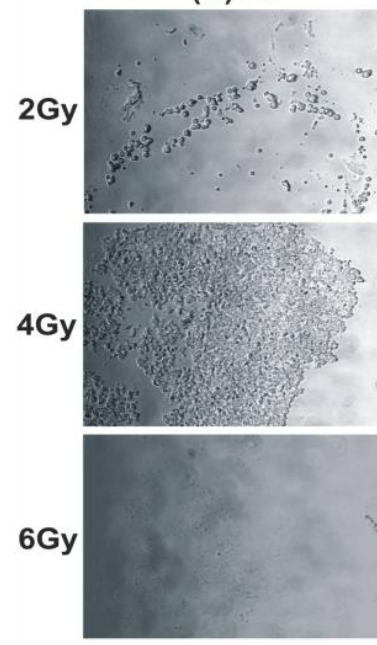

(G) BF

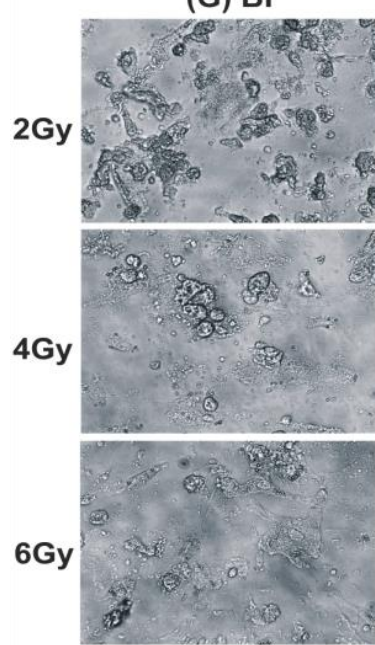

(E) Collagen-II +ve

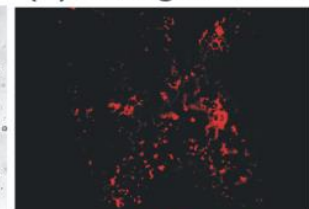

(F) Alcian Blue/NR

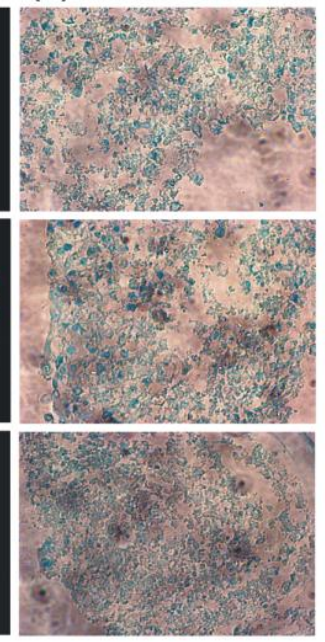

(I) Alizarin-Red

(H) Osteopontin +ve

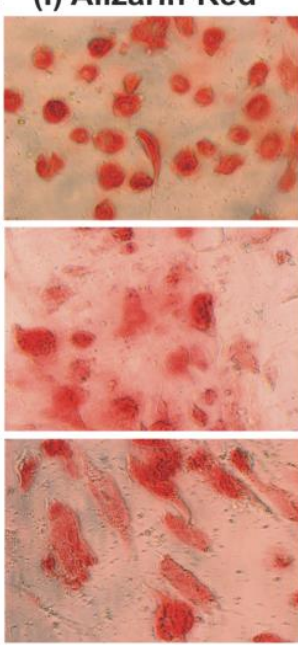


Figure.4.8.2.1.Supplemental: aMSCs multi-lineage differentiation after ionizing radiation (complementary of Figure.4.5.1)

24 hours after being irradiated with 2, 4 and 6 Gy, exponentially growing aMSCs were differentiated to adipocytes $(A, B, C)$, chondrocytes $(D, E, F)$, and osteocytes $(G, H, I)$. After 14-21 days, cells were fixed, and saved for immunohistochemistry (IHC). (A) Represents the bright field (BF) image of the corresponding mouse fatty acid binding protein-4 (FABP-4)positive newly formed adipocytes (red, FABP-4 +ve) shown in (B). (C) Represents the Oil-RedO staining of the fat droplets inside newly formed adipocytes (dark red). (D) Represents the bight field (BF) image of the corresponding collagen-II positive newly formed chondrocytes (red) shown in (E). (F) Represents the Alcian-Blue staining of sulphated mucin (blue) and Neutral Red (NR) staining of the lysozymes (red) inside newly formed chondrocytes. (G) Represents the bight field (BF) image of the corresponding osteopontin-positive newly formed osteocytes (red, Osteopontin +ve) shown in (H). (I) Represents the Alizarin-Red staining of calcium deposits inside newly formed osteocytes (red). Images magnification is $40 X$. 

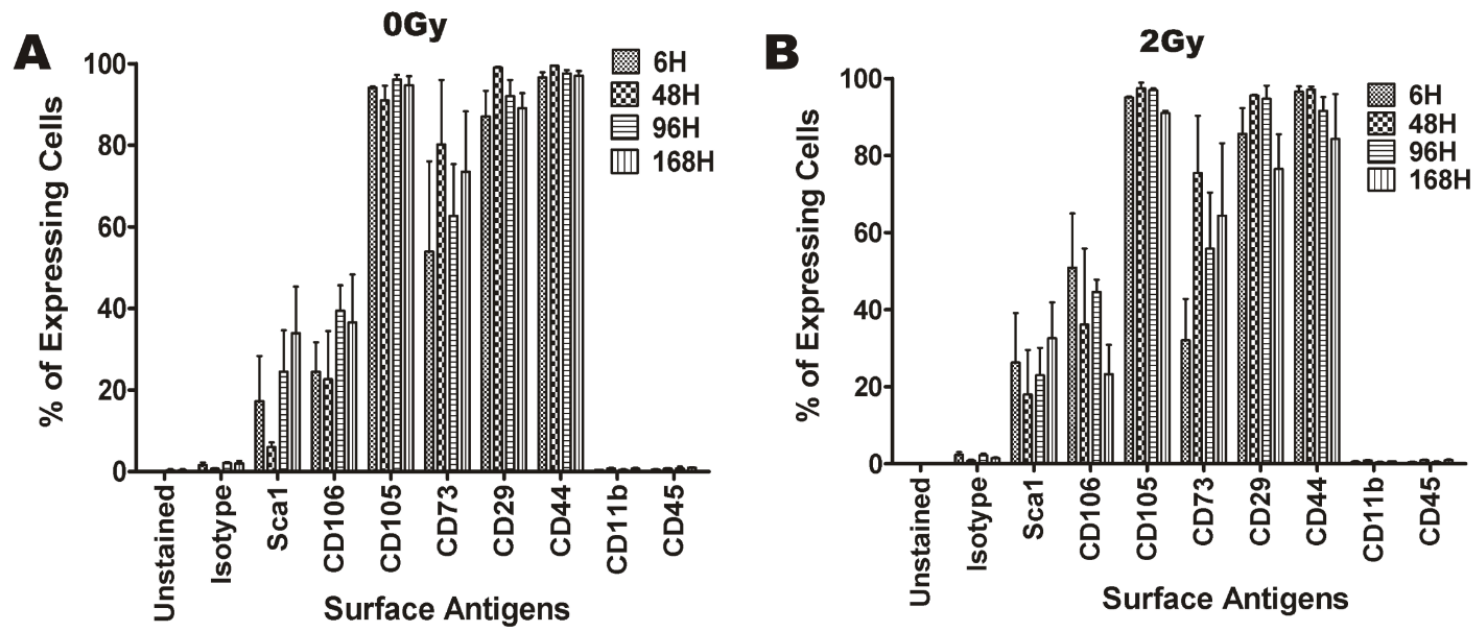

C

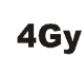

D

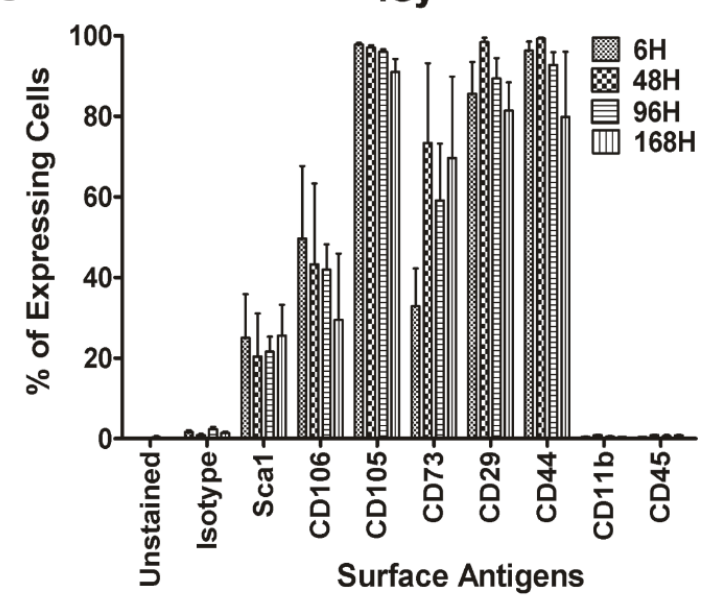

E 8Gy
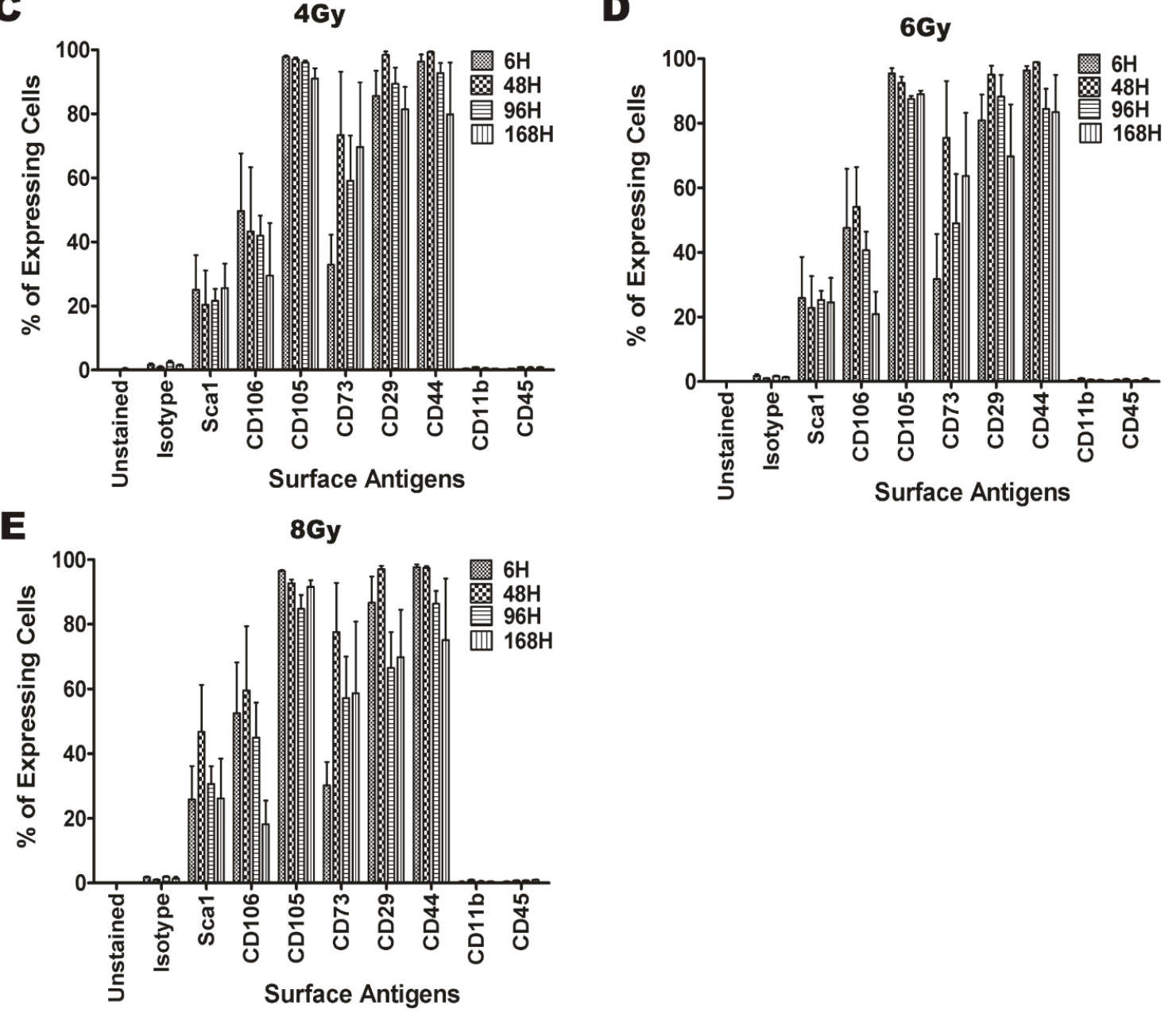
Figure 4.8.2.2.Supplemental: MSCs surface antigens expression in aMSCs after different radiation doses up to 7 days after irradiation

Non-irradiated aMSCs (A) and irradiated aMSCs with 2, 4, 6 and 8 Gy (B, C, D and E, respectively) were analyzed by FC for surface antigens expected on Mesenchymal Stromal/Stem Cells (MSCs), i.e. Sca1, CD106, CD105, CD73, CD29 \& CD44, as well as those absent on MSCs since typical of Hematopoietic Stem Cells (HSCs), i.e. CD11b and CD45 at different time points (6-168 hours) after IR. $\mathrm{n}=4$ for each radiation dose. Data presented as the mean \pm the standard error of the mean (SEM). 
(N)

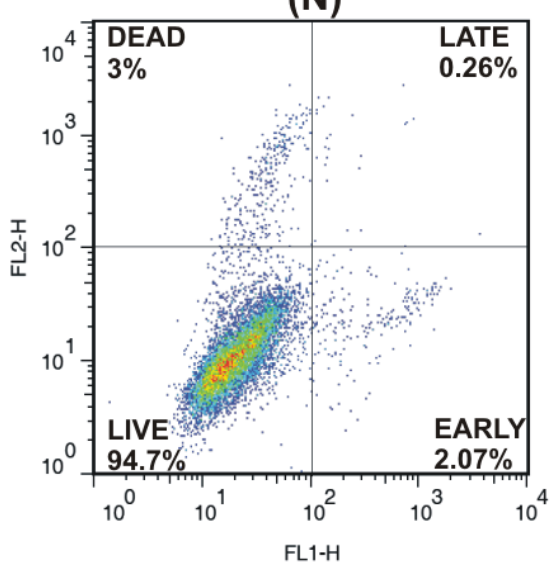

(24 hrs)

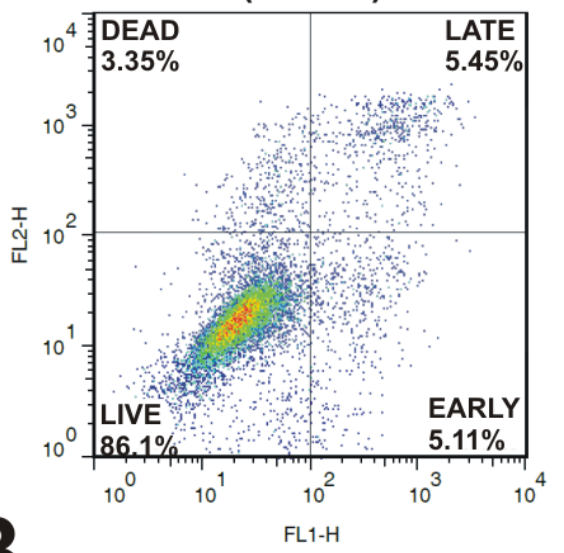

B

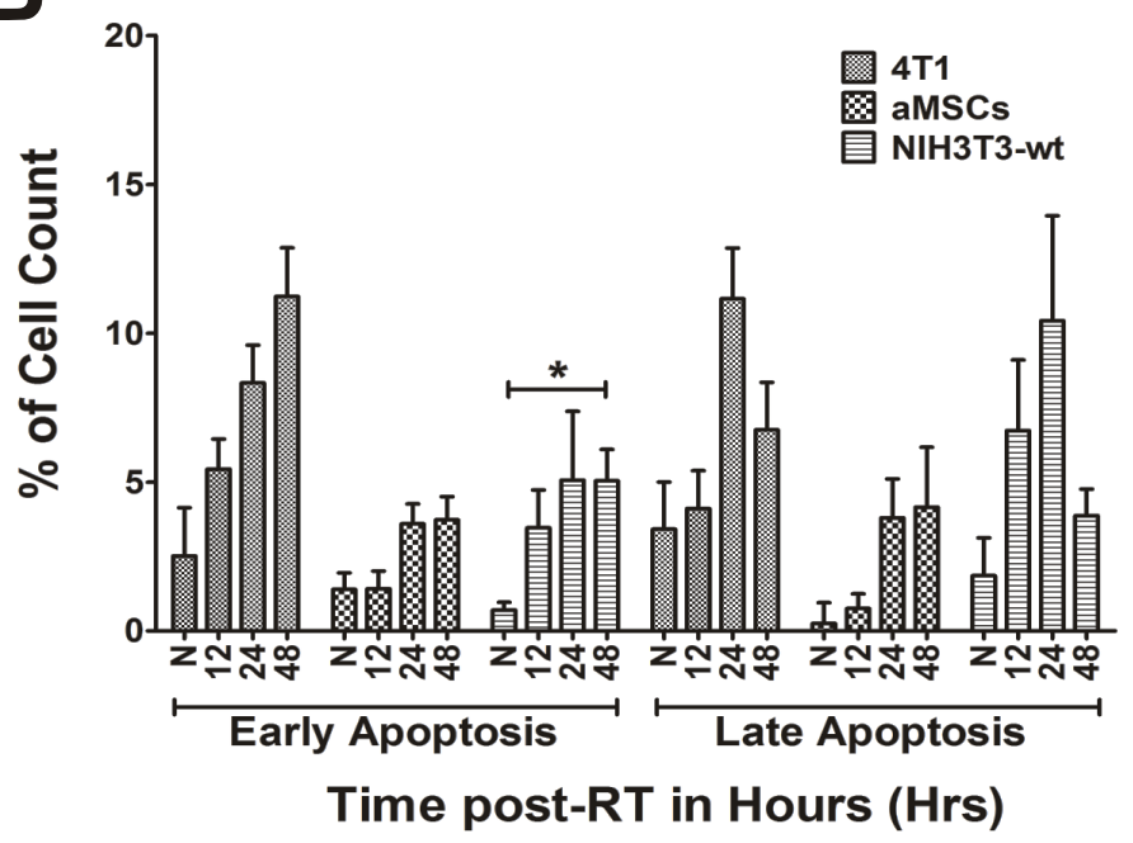

(12 hrs)

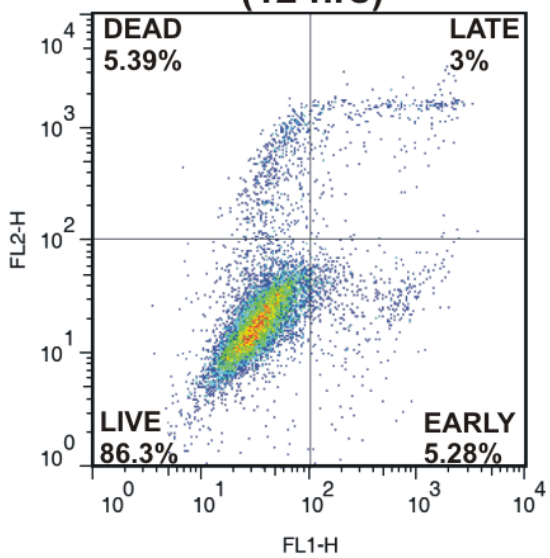

(48 hrs)

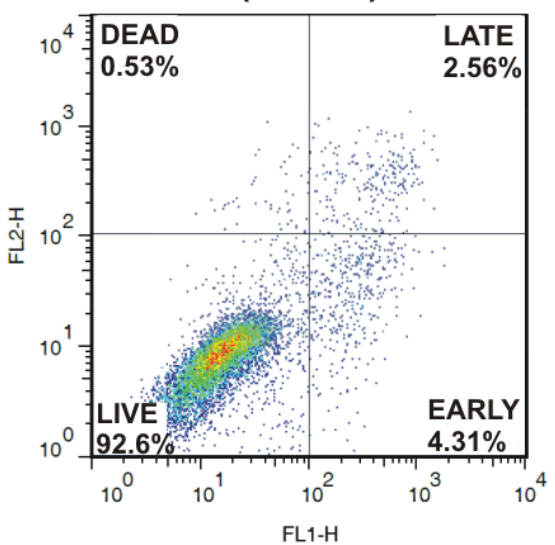

4T1

aMSCs

H3T3-wt 
Figure.4.8.2.3.Supplemental: Annexin-V/PI Apoptosis Assay

aMSCs, 4T1 and NIH3T3-wt cells were irradiated with 6 Gy and analyzed with flow cytometry (FC) after being stained for FITC-conjugated Annexin-V and Propidium lodide (PI) at 12, 24 and 48 hours after irradiation. $(N)=$ non-irradiated cells, $(D E A D)=$ dead cells, $($ LATE $)=$ late apoptotic cells, $($ EARLY $)=$ early apoptotic cells and (LIVE) = live cells. (A) Represents FC analysis of irradiated aMSCs cells showing both early and late apoptosis percentages of the cells after IR. (B) Represents the average of three experiments for early apoptosis and late apoptosis comparing 4T1, aMSCs and NIH3T3-wt cells. ${ }^{*}=$ P-value $<0.05$. We treat the cells with $20 \mu \mathrm{M}$ Camptothecin for 48 hours as a positive control apoptotic agent. $(n=3)$ and Data presented as the mean \pm the standard error of the mean (SEM). 
This page is intentionally left blank 
The next chapter represents our $2^{\text {nd }}$ manuscript showing our study for the generation of our single dose radiation-induced oral mucositis (RIOM) mouse model considering the following objective:

1- Generate a RIOM mouse mode with the highest tolerated dose and the longest possible inflammatory and ulcerative phase.

2- Setting up clinically relevant and histological parameters to accurately quantify the severity and the duration of the injury. 3- Improve animal survival during the post-irradiation period. 


\section{Chapter 5 SINGLE DOSE RADIATION-INDUCED ORAL MUCOSITIS MOUSE MODEL}

Osama Muhammad Maria, MD, MSc ${ }^{1,2,3}$, Alasdair Syme, $\mathrm{PhD}^{3,4,6}$, Nicoletta Eliopoulos, $\mathrm{PhD}^{2,5}$ and Thierry Muanza, MD, $\mathrm{MSc}^{1,3,5,6}$

1 Experimental Medicine Department, Faculty of Medicine, McGill University, Montreal, Quebec, Canada

2 Surgery Department, Faculty of Medicine, McGill University, Montreal, Quebec, Canada

3 Radiation Oncology Department, Jewish General Hospital, McGill University, Montreal, Quebec, Canada

4 Medical Physics Unit, McGill University, Montreal, Quebec, Canada

5 Lady Davis Institute for Medical Research, Jewish General Hospital, McGill University, Montreal, Quebec, Canada

6 Oncology Department, McGill University, Montreal, Quebec, Canada

\section{AUTHOR CONTRIBUTIONS}

- Osama Maria: Conception and design, collection and/or assembly of data, data analysis and interpretation, manuscript writing, final approval of manuscript.

- Alasdair Syme: Conception and design

- Nicoletta Eliopoulos: Conception and design, provision of study material, data analysis and interpretation, final approval of manuscript. 
- Thierry Muanza: Conception and design, financial support, provision of study material, data analysis and interpretation, final approval of manuscript.

\author{
THE CORRESPONDING AUTHOR \\ Dr. Thierry Muanza, MD MSc FRCPC \\ Radiation Oncology Translational Research Lab, \\ Department of Radiation Oncology, \\ Jewish General Hospital and Lady Davis Institute Research Centre, \\ McGill University, \\ 3755 Côte-St.-Catherine Road, Suite G002, \\ Montréal, Québec, \\ Canada, H3T 1E2 \\ Tel: +1 (514)-340-8288, \\ Fax: +1 (514)-340-7548, \\ Email:tmuanza@yahoo.com
}




\subsection{ABSTRACT}

Objective: This article documents the generation of self-resolved radiation-induced oral mucositis (RIOM) male mouse model with the highest tolerable single radiation (RT) dose to be used in studying RIOM management.

Methods: We used 10 week-old male BALB/c mice with average weight of $23 \mathrm{gm}$. They were treated with an orthovoltage X-ray irradiator to induce RIOM ulceration at the intermolar eminence of the animal tongue. General anesthesia injected intraperitoneally was used for proper animal immobilization.

Results: A single dose irradiation of 10, 15, 18, 20, and 25 Gy generated a RIOM ulcer at intermolar eminence (posterior upper tongue surface) with mean ulcer floor (posterior epithelium) heights of $190,150,25,10$, and $10 \mu \mathrm{m}$ compared to $200 \mu \mathrm{m}$ in non-irradiated animals 10 days after irradiation. The mean RIOM ulcer size $\%$ of the total epithelialized upper surface of the tongue was radiation (RT) dose-dependent. At day 10 , the ulcer size $\%$ was $2 \%, 5 \%, 27 \%$, and $31 \%$ for $15,18,20$, and 25 Gy $\mathrm{RT}$, respectively. The mean relative surface area of the total epithelialized upper surface of the tongue was dose dependent. At day 10, it was significantly decreased to $97 \%, 95 \%, 88 \%$, and $38 \%$ with $15,18,20$, and 25 Gy RT, respectively. 4 doses of subcutaneous injection of $1 \mathrm{~mL}$ of $0.9 \%$ saline / 6 hours yielded a $100 \%$ survival of the 18 Gy self-resolved RIOM which had $5.6 \pm 0.3$ days ulcer duration.

Discussion and conclusion: We generated a 100\% survival self-resolved single dose radiation-induced oral mucositis male mouse model usable for research 
purposes. Oral mucositis ulceration was dose dependent. Sufficient hydration of animals after radiation exposure significantly improved their survival. 


\section{KEYWORDS}

Epithelium, Hydration, Inflammation, Mouse Model, Normal Tissue Injury, RadiationInduced Oral Mucositis, Radiation Therapy, Tongue 


\subsection{INTRODUCTION}

Radiation-induced oral mucositis (RIOM) is a normal tissue injury side effect of radiation (RT) therapy with an $80 \%$ incidence in in Head and Neck cancer patients [1, 2]. In 2004, Scull et al. proposed 4 inflammatory stages during the clinical course of RIOM which is considered a major dose-limiting toxicity [3, 4]. RIOM clinical progress includes localized asymptomatic hyperemia and edema, then ulceration and confluent desquamation, then necrosis and possible secondary infection, then final fibrosis and/or repopulation (3). RIOM narrow therapeutic ratio leads to alteration in $\mathrm{RT}$ dose fractionation protocols, treatment interruptions, and poor local tumor control that can affect the long-term survival. Although considered a self-limited inflammation if the patient survives, RIOM could lead to a significant decline in patient's quality of life in elderly sick patients potentially necessitating alterations of the planned course of RT to lethal deterioration $[1,5,6]$.

The need to generate a stable and well characterized RIOM mouse model will facilitate the current and future research studies to repair such radiation-induced normal tissue injury. Some mouse models have been created in separate studies for both the fractionated [15, 39, 48, 49] and the single dose RT [1, 50-53]. However, the short duration of such RIOM resulted in limitations in the experimental setup and performance. A study had recorded a fractionated dose RIOM ulcer duration mean of $2.9 \pm 0.7$ days [48] $(\mathrm{M} \pm S \mathrm{~S})$ and a single dose RIOM ulcer duration of $2.0 \pm 0.4$ days $(\mathrm{M} \pm \mathrm{SD})$ [72]. For that reason, we were interested to generate a RIOM mouse model with longer inflammatory and ulcerative phase duration that will allow for better experimentation and investigation of many injury variables within the same 
experiment, especially in translational research. That will lead to the generation of finer injury quantification and describing parameters to allow better RIOM injury control and therapy.

Our objective was to determine the highest single RT dose that will give a longer nonlife threatening self-resolved RIOM in mice with the longest possible inflammatory and ulcerative phase. In addition, we aimed to characterize such injury histologically in order to precisely quantify the injury at that radiation dose for better treatment evaluation parameters.

\subsection{MATERIALS AND METHODS}

\subsubsection{Single dose RIOM mouse model}

All animal handling was done according to McGill University's Standard Operating Procedures (SOPs) and the Canadian Council of Animal Care (CCAC). 8 week-old male BALB/c mice were purchased from Charles River ${ }^{\circledR}$ (Montreal, QC, Canada). Experiments were performed 2 weeks after the animal adjustment period was completed at the animal facility. Generation of single dose RIOM was done using Gulmay ${ }^{\circledR}$ orthovoltage X-ray D3225 irradiator (Suwanee, GA, USA) according to the following protocol. Average $25 \mathrm{gm}$ weighted $10 \mathrm{wk}$-old male BALB/c mice were anaesthetized by Ketamine/Xylazine/Acepromazine anesthesia, $0.05-0.1 \mathrm{~mL} / 10 \mathrm{gm}$, intraperitoneally, and protective ophthalmic ointment (natural tears) was applied (according to McGill University SOP-110). Mice were transferred to the radiation facility afterwards on electrical warming blankets. Animals were placed side-by-side in the prone along the borders of a $20 \times 20 \mathrm{~cm}$ square cone (4 or 5 animals per side) in a position that only allows the animal's head to be irradiated (area from the mid- 
ear coronal plane till the tip of the nose was placed internally underneath the cone while the remaining animal body was outside the radiation field). We used an energy of $120 \mathrm{kVp}$ and a central output of $115.8 \mathrm{cGy} / 100$ monitor units (MU). Ionization chamber dosimetry was used to quantify the slightly reduced radiation dose near the periphery of the radiation field (where the mouse heads were located) and the number of $\mathrm{MU}$ was adjusted to compensate. We delivered 10, 15, 18, 20, and 25 Gy to induce RIOM. Animals were always kept on warm blankets to avoid hypothermia. After irradiation, animals were kept in $33^{\circ} \mathrm{C}$ incubator for 2 hours until complete recovery with subcutaneous hydration that continued for 24 hours after $\mathrm{RT}$, (1 mL $0.9 \%$ saline subcutaneously / 6 hours for 24 hours). Animals were moved to their cages with free access to enriched jelly food (Bio-Serv ${ }^{\circledR}$ Rodent Liquid Diet, AIN-76 served with $15 \% \mathrm{w} / \mathrm{v}$ gelatin) and water with daily observation. The primary and clinically relevant end-point was established as grade 3 RIOM by RTOG/EORTC scale version.2. [48, 72].

\subsubsection{Tissue collection and processing}

At different time points (indicated for each experiment), animals were sacrificed and after cervical dislocation, complete tongue tissue and salivary gland were carefully dissected and placed immediately into cold 1X PBS. Tongue was stained with $1 \%$ toluidine blue (TB) in 10\% acetic acid. Repeated wiping with acetic acid-soaked gauze was applied until no more dye could be recovered from the tissue [1]. After macroscopical analysis of RIOM, tongue tissue was dissected longitudinally in the median plane (dividing the ulcer into identical halves), kept in 10\% buffered formalin, and then the tongue tissue was paraffin embedded and $3 \mu \mathrm{m}$ sections were made 
for H\& E staining and microscopic analysis. Many clinical and histological parameters for quantification of the RIOM were applied, e.g. we used ulcer size and ulcer size \% (Image $J^{\circledR}$ software measured surface area in pixels was used for the ulcer size percentage of the total tongue epithelialized upper surface), ulcer duration, ulcer time-to-appear (latency), ulcer time-to-heal, posterior upper surface epithelium height (intermolar eminence epithelium height) and cellularity (infiltrating cells) as histological and clinically relevant parameters to quantify RIOM. In addition to animal weight in relation to RIOM phase and severity.

\subsection{STATISTICS}

GraphPad Prism ${ }^{\circledR}$ software (version 5.01) was used for statistical analyses. Data were expressed as the mean $(\mathbf{M}) \pm$ the standard error of the mean (SEM). The paired two-tailed Student's t-test was applied for two sets of data. P-value $<0.05$ was considered a significant difference.

\subsection{RESULTS}

\subsubsection{RIOM is a radiation dose dependent injury}

RIOM ulceration was localized to the intermolar eminence of the animal tongue, which is located at the upper posterior surface. All RT doses caused partial or complete loss of the eminence at day 7 after RT (Figure.5.8.2.1.Supp). The TB stained RIOM ulceration was evident with all RT doses except 10 Gy, which produced a very limited epithelial loss at the eminence; however, it showed marked cellular infiltration similar to other RT doses. All other RT doses showed complete loss of the eminence macroscopically. H\& E staining showed complete loss of the 
eminence epithelium with RT doses of 15, 18, 20, and 25 Gy marked by the deep blue coloration of the TB. Ulceration was detectable at day 9 after RT in all experiments, while the eminence loss started at least 2 days earlier (Figure.5.8.2.1.Supp). Collected salivary glands showed marked reduction in their total volume with all RT doses compared to non-irradiated animals (Figure.5.5.1.A). We found that the mean size percentage of RIOM ulcer relative to the total epithelialized upper surface of the tongue was RT dose dependent. More precisely, on day 10 after RT, it was $2 \%, 5 \%, 26 \%$, and $32 \%$ of the total epithelialized upper surface of the tongue for RT doses of $15,18,20$, and 25 Gy, respectively. However, on day 14, 15 Gy-generated ulcer was cured, and the 25 Gy-irradiated animals were dead due to extensive inflammation and dehydration while 18 and 20 Gy-generated ulcers were in the process of being repaired and still detectable by TB staining (Figure.5.5.1.B).

We measured the RIOM ulcer floor epithelium height (eminence epithelium). We noted that although almost all epithelial layers were desquamated, there were still measurable micrometers of the epithelium (Figure.5.5.1.A), we can see also the marked increased in infiltrating cells at the sub-epithelial connective tissue as a sign of the inflammatory response. 10 Gy produced minimal reduction in epithelium height, while it was more substantial than 15 Gy RT dose at day 10 after RT. However, the significant difference was documented only with 18, 20 and 25 Gy irradiation from day 9 to day 13, (Figure.5.5.1.C) shows day 10 epithelium height in $\mu \mathrm{m}$. 
We measured the total epithelialized upper surface of the tongue in both nonirradiated and irradiated animals. We found significant reduction in the total area of the epithelialized upper surface of the tongue with all irradiation doses ( $p$-value $<$ 0.05-0.00005). In addition, we found that the mean of the relative total epithelialized upper surface area was RT dose dependent with all RT doses, (relative = total epithelialized upper surface area of the tongue of irradiated animals / total epithelialized upper surface area of the tongue of non-irradiated animals). The mean of the relative total epithelialized upper surface was $97 \%, 95 \%, 89 \%, 65 \%$, and $39 \%$ with $10,15,18,20$, and 25 Gy, respectively at day 10 after RT. The epithelium surface area reduction reached maximum at days 9 to 11 after $\mathrm{RT}$, then the surface area started to increase afterwards to reach the normal range 3 weeks after RT. At day 14 , animals irradiated with smaller doses started to recover (for example, 10 Gyirradiated animals lost the significant surface area reduction at that time due to increased epithelial height), while animals irradiated with 25 Gy could not survive the severe inflammation (Figure.5.5.1.D, and Figure.5.5.2.D). We noted that there was significant improvement of animal survival with more hydration provided during the post-irradiation period. 


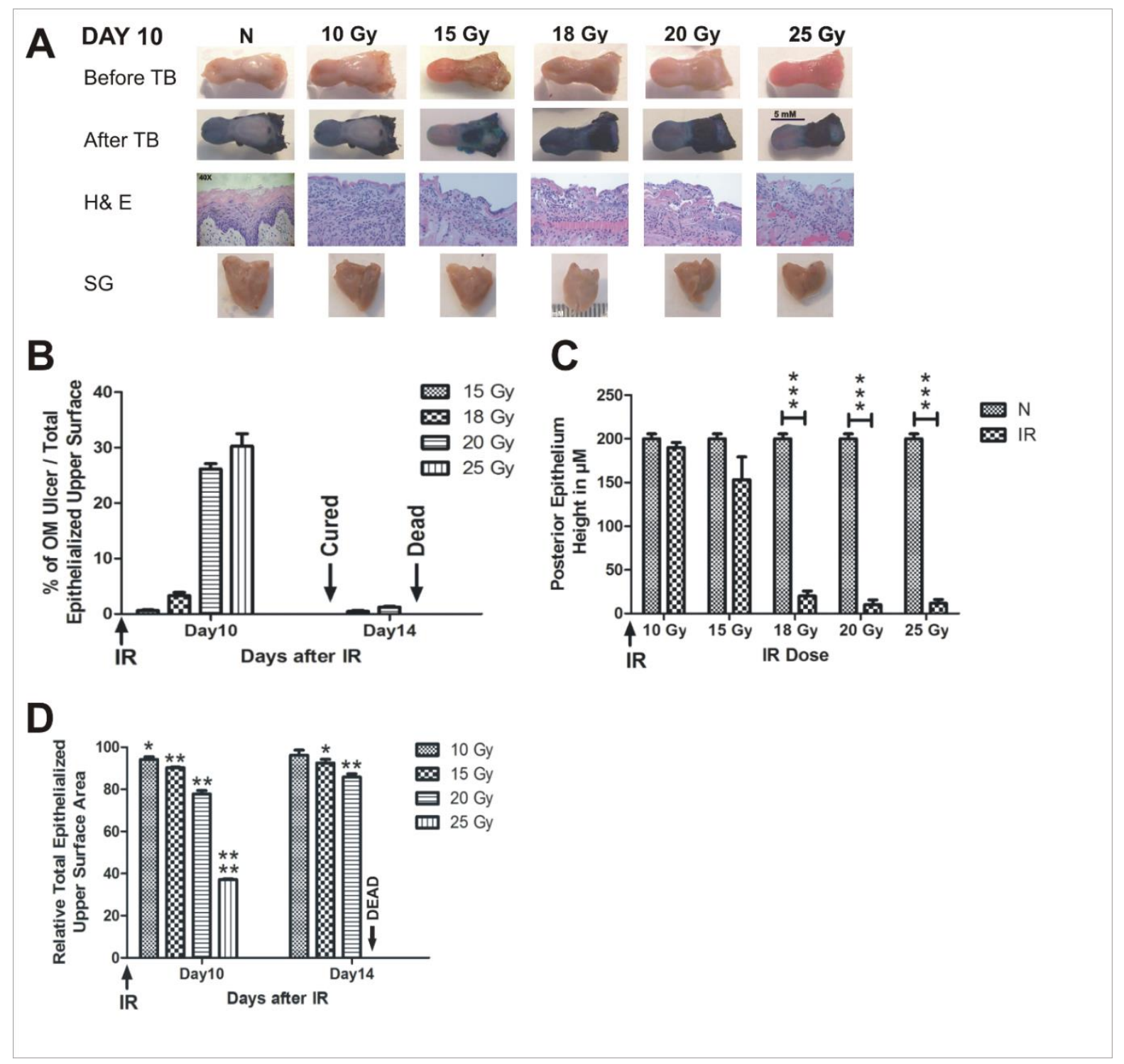

Figure.5.5.1: RIOM is a radiation dose dependent injury

10 week-old mice were irradiated (IR) with a single dose of $10,15,18,20$, or 25 Gy at day 0 (4 animals / dose). Animals were sacrificed at different time points, and tongues and salivary glands were collected. Tongues were stained with $1 \%$ TB in $10 \%$ acetic acid. After tongue imaging, the ulcer size and the total epithelialized upper surface of the tongue were measured in both non-irradiated $(\mathrm{N})$ and irradiated animals at different RT doses. Then, tongues were kept in $10 \%$ buffered formalin until the time of paraffin embedding. After 
embedding, $3 \mu \mathrm{m}$ sections were stained with H\& E. (A) Represents animals' tongues before and after TB staining showing the posterior epithelium ulceration (in blue) at the intermolar eminence of the tongue, H\& E staining, and salivary glands (SG) at day 10 after RT. (B) Represents the mean percentage of oral mucositis (OM) ulcer size of the total epithelialized upper surface of the tongue. (C) Represents the mean of the posterior epithelium height (ulcer floor within the intermolar epithelium) at different RT doses compared to nonirradiated animals (N) at day 10 irradiation. (D) Represents the mean relative total epithelialized upper surface area (relative = surface area in RT animal group/ surface area in $N$ animal group). Data from days 10 and $14(n=3)$, data presented as the mean \pm the standard error of the mean. ${ }^{*}=p$-value $<0.05,{ }^{* *}=p$-value $<0.005,{ }^{* * *}=p$-value $<0.0005$, and $=p$-value $<0.00005$.

\subsubsection{Self-resolved single dose RIOM with $100 \%$ survival rate}

We were able to generate a self-resolved single dose RIOM BALB/c male mouse model with $100 \%$ survival using the lowest possible RT dose, 18 Gy. We quantified the results as the mean $(\mathbf{M}) \pm$ the standard error of the mean (SEM). RIOM ulcer started at day 9 (as evidenced by deep blue staining with TB) and resolved by day (15) in almost all experiments. With a single dose of 18 Gy, considering that the RT

day is day 0 , we achieved a self-resolved RIOM ulceration of $5.6 \pm 0.3$ days duration (95\% confidence interval 4.233-7.1 days), ulcer time-to-appear (latency) at $9.3 \pm 0.3$ days (95\% confidence interval 7.867-10.733 days), and ulcer time-to-heal at $15 \pm$ 0.58 days ( $95 \%$ confidence interval $12.517-17.483$ days). The RIOM ulcer was always at the posterior dorsal surface of the tongue where the intermolar eminence 
is located anatomically, called posterior epithelium or eminence epithelium (Figure.5.5.2.A).

After 18 Gy RT, animals showed the largest ulcer mean size at days 9 and 11 after RT. Ulcer size was $5.7,5.6,5.0,0.4,0 \mu m^{2}$ at days $9,11,13,15,21$, respectively (Figure.5.5.2.B). The RIOM ulcer size percentage to the total epithelialized upper surface of the tongue was the highest at day 13 after RT. Ulcer size percentage was $16 \%, 18.5 \%, 12 \%, 0.9 \%$, and $0 \%$ at days $9,11,13,15,21$, respectively.

Ulcer size was dependent on the stage of the RIOM, which resolved by $15 \pm 0.58$ days, nevertheless, the epithelium was completely recovered to normal mean heights at day 21 after RT (Figure.5.5.2.A, B, and C).

The relative total epithelialized upper surface of the tongue was RIOM stage dependent. The lowest surface area was recorded at days 9 and 11 after RT, which corresponds to the largest recorded RIOM ulcer size. The mean of the relative total epithelialized upper surface was $60 \%, 59 \%, 78 \%, 89 \%$, and $100 \%$ at days $9,11,13$, 15, 21, respectively (Figure.5.5.2.D).

Animal weight loss and gain were significant parameters for the severity, the degree and the stage of the RIOM. After RT of 18 Gy, irradiated animals started to lose weight significantly ( $p$-value $<0.005$ ) which reached the minimum by days 13 and 15 , (p-value $<0.000005$, and 0.00005 , respectively), which are the days following the largest ulcer size at days 9 and 11 , then started to gain weight up to normal ranges by day 21 after RT (Figure.5.5.2.E). In addition, we noted a RT-dependent reduction of the salivary gland volume that was parallel to the reduction in the total 
epithelialized upper surface of the tongue, which reflects the animal's nutritional and hydration status (date not quantified).

We documented significant improvement of the survival of RIOM animals in experiments with hydration doses of $1 \mathrm{~mL}$ of $0.9 \%$ saline subcutaneously / dose. This significant survival improvement was maximal with 4 doses of hydration, one dose every 6 hours for a total of 24 hours after RT. The percentage survival was $63 \%$ with no hydration, and $72 \%, 88 \%$, and $100 \%$ with 1,2 , and 4 doses of hydration with $1 \mathrm{~mL}$ subcutaneous $0.9 \%$ saline / dose / 6 hours after RT (p-values $<0.05$, 0.005, and 0.0005, respectively for 1, 2, and 4 hydration doses) (Figure.5.5.2.F). 
A

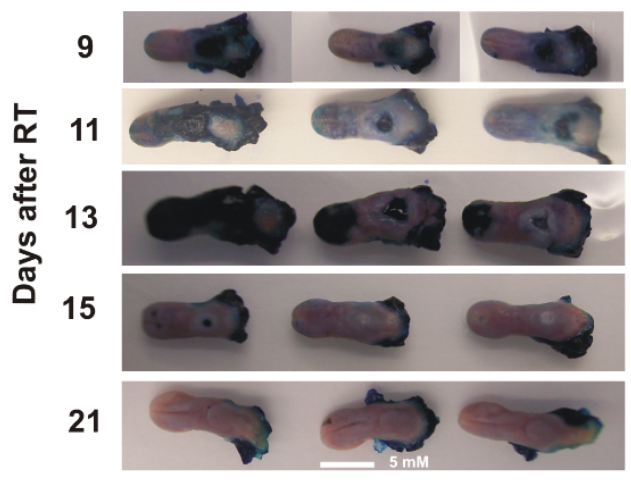

C

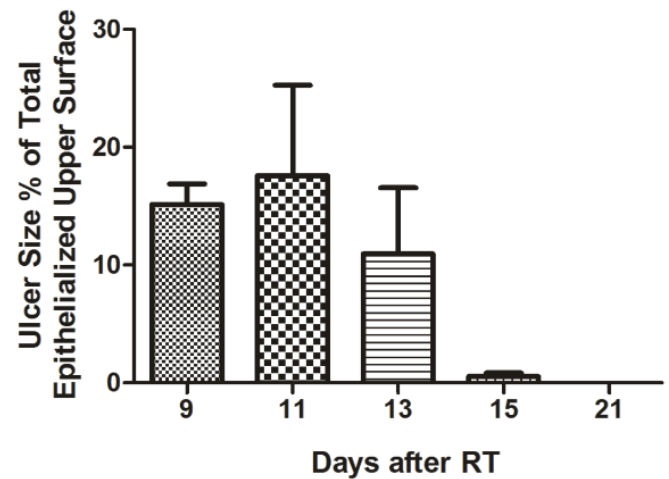

$\mathbf{E}$

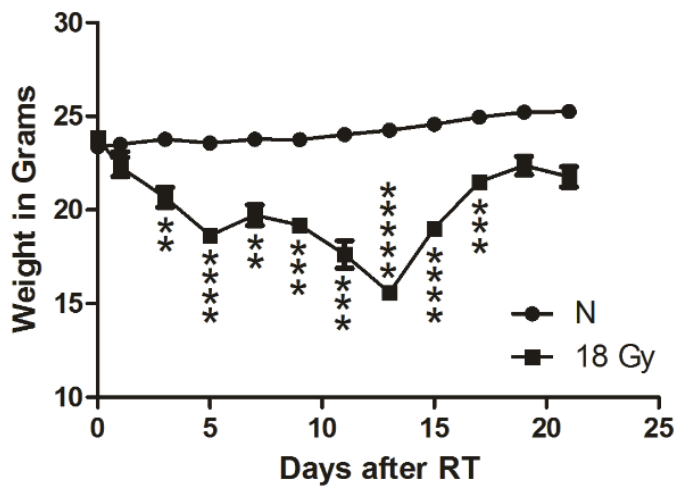

B

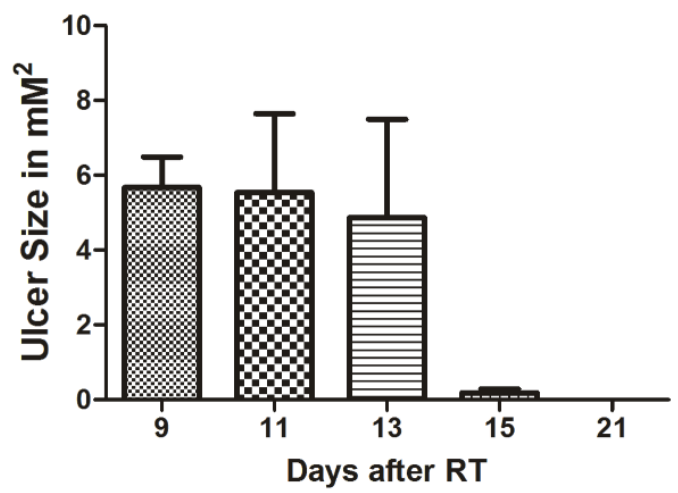

D

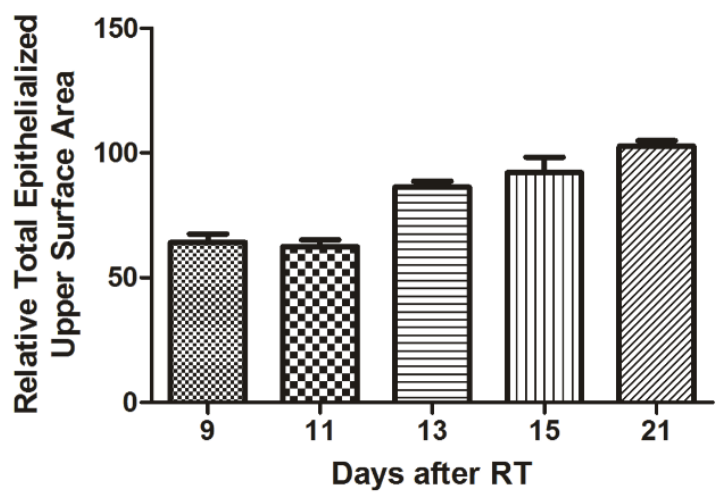

$\mathbf{F}$

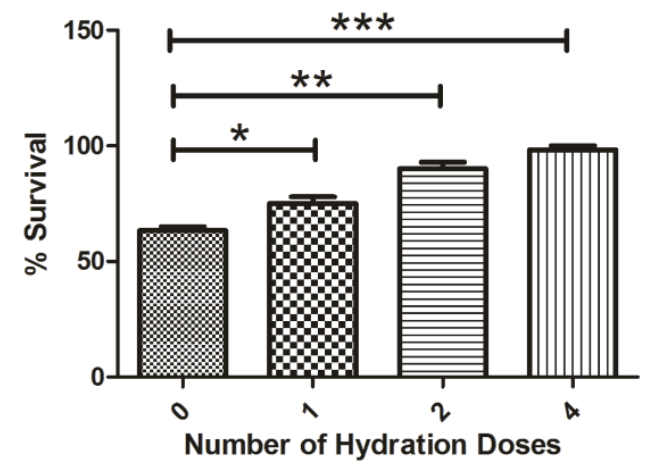

Figure.5.5.2: RIOM model was established with a single RT dose of $18 \mathrm{~Gy}$

10 week-old mice were irradiated with a single dose of 18 Gy at day 0, 5 animals / time point.

Animals were sacrificed at different time points and tongues were collected. Tongues were

stained with $1 \%$ TB in $10 \%$ acetic acid. After tongue imaging, the ulcer size and the total 
epithelialized upper surface of the tongue were measured. We measured the animal weight every other day for 3 weeks after RT. (A) Represents the RIOM TB stained ulcers at the intermolar eminence of the tongue at different time points. (B) Represents the mean RIOM ulcer size in $\mathrm{mm}^{2}$ (C) Represents the mean ulcer size percentage to the total epithelialized upper surface of the tongue. (D) Represents relative total epithelialized upper surface area. (E) Represents the mean animal weight for 3 weeks after RT. (F) Represents the percent survival of different hydration regimens used at the post-irradiation period. $(n=3)$, data presented as the mean \pm the standard error of the mean. ${ }^{* *}=p$-value $<0.005,{ }^{* * *}=p$-value $<0.0005,{ }^{* * * *}=\mathrm{p}$-value $<0.00005$, and ${ }^{* * * * *}=\mathrm{p}$-value $<0.000005$

\subsection{DISCUSSION}

We used grade 3 RIOM by RTOG/EORTC scale, Version.2, as our clinically relevant end point in generating our RIOM mouse model. Grade 3 signifies the presence of ulceration, extensive erythema, and inability to swallow hard food [4]. As documented by Muanza, T.M., et al. and Schmidt, M., et al. [1, 72], we showed that RIOM severity is RT dose dependent. In addition to histological evidences of RIOM, macroscopical imaging showed earlier signs of intermolar eminence loss at least 48 hours before the physical appearance of the ulcer on day 9. This finding was in agreement with what has been documented before using optical coherence tomography [1]. The volume reduction noted in both tongue and salivary gland could be partially explained by the physical obstruction of food and fluid intake due to ulceration in addition to the systemic inflammatory reaction that disturbed the volume regulatory mechanism. We found a close correlation between the total epithelialized 
upper surface of the tongue and the animal weight. Animal weight started to catch up at least 48 hours after the lowest total epithelialized upper surface had been recorded. Our results showed that proper hydration after RT is a critical life-saving procedure that is highly recommended for all post-irradiation care regimens.

We preferred using the ulcer size percentage to the total epithelialized upper surface of the tongue to express the severity and the stage of RIOM in order to overcome the minimal individual variation in tongue size between animals of the same age. We were able to precisely identify the lowest single dose (18 Gy) delivered by orthovoltage RT to generate a self-resolved RIOM of $5.6 \pm 0.3$ days duration in BALB/c male mice. In addition, we were able to achieve a $100 \%$ survival rate after improving the post-irradiation hydration regimen. Those two achievements will significantly improve future studies on RIOM, mainly in translational research, where reliable clinically relevant therapeutic benefits are needed in a time-efficient manner. A mean RIOM ulcer duration of 5.6 days widened the tight ulcer duration recorded in earlier studies with artificial techniques $[49,50]$.

Our single dose RIOM has an ulceration with the longest recorded duration. Such long RIOM ulcer duration will allow for better experimentation and investigation of many injury variables within the same experiment, especially in translational research. That will lead to the generation of finer injury quantification and describing parameters to allow better RIOM injury control and therapy. 


\subsection{CONCLUSION}

In radiation-induced oral mucositis, ulcer size, total upper epithelialized tongue surface, and intermolar epithelium height were radiation dose dependent. We generated a self-limited single dose radiation-induced oral mucositis mouse model of $5.6 \pm 0.3$ days physical ulcer duration, $9.3 \pm 0.3$ days ulcer latency, $15 \pm 0.56$ ulcer time-to-heal, and $100 \%$ survival with 18 Gy orthovoltage radiation. Beyond 18 Gy of orthovoltage radiation, mice could not survive beyond 10 days due to severe mucositis that resulted in uncorrectable weight loss and dehydration. We recommend the use of animal weight loss as one important parameter for the severity, and stage of the mucositis. We also recommend using the total tongue epithelialized upper surface as an indicator of mouse hydration status. More studies are needed to identify a parallel fractionated-dose mouse model with orthovoltage Xrays radiation. Our model achieved a longer physical ulcer duration with measurable tongue upper surface epithelium (ulcer floor). We found a relation between the injury severity and stage and the mouse weight. Our model showed better survival rates with improved post-irradiation hydration regimen. Our findings will improve the future experimentation technicality for better management of radiation-induced oral mucositis.

\section{AKNOWLEDGEMENT}

Osama Muhammad Maria is an awardee of the LDI/TD studentship. This study was supported partially by Ride To Conquer Cancer (RTCC, Jewish General Hospital Foundation) and Fonds de Recherche du Quebec - Santé (FRQS) grants. 
DISCLOSURE OF POTENTIAL CONFLICT OF INTEREST

None. 


\subsection{SUPPLEMENTAL DATA}

\subsubsection{Supplemental figures}

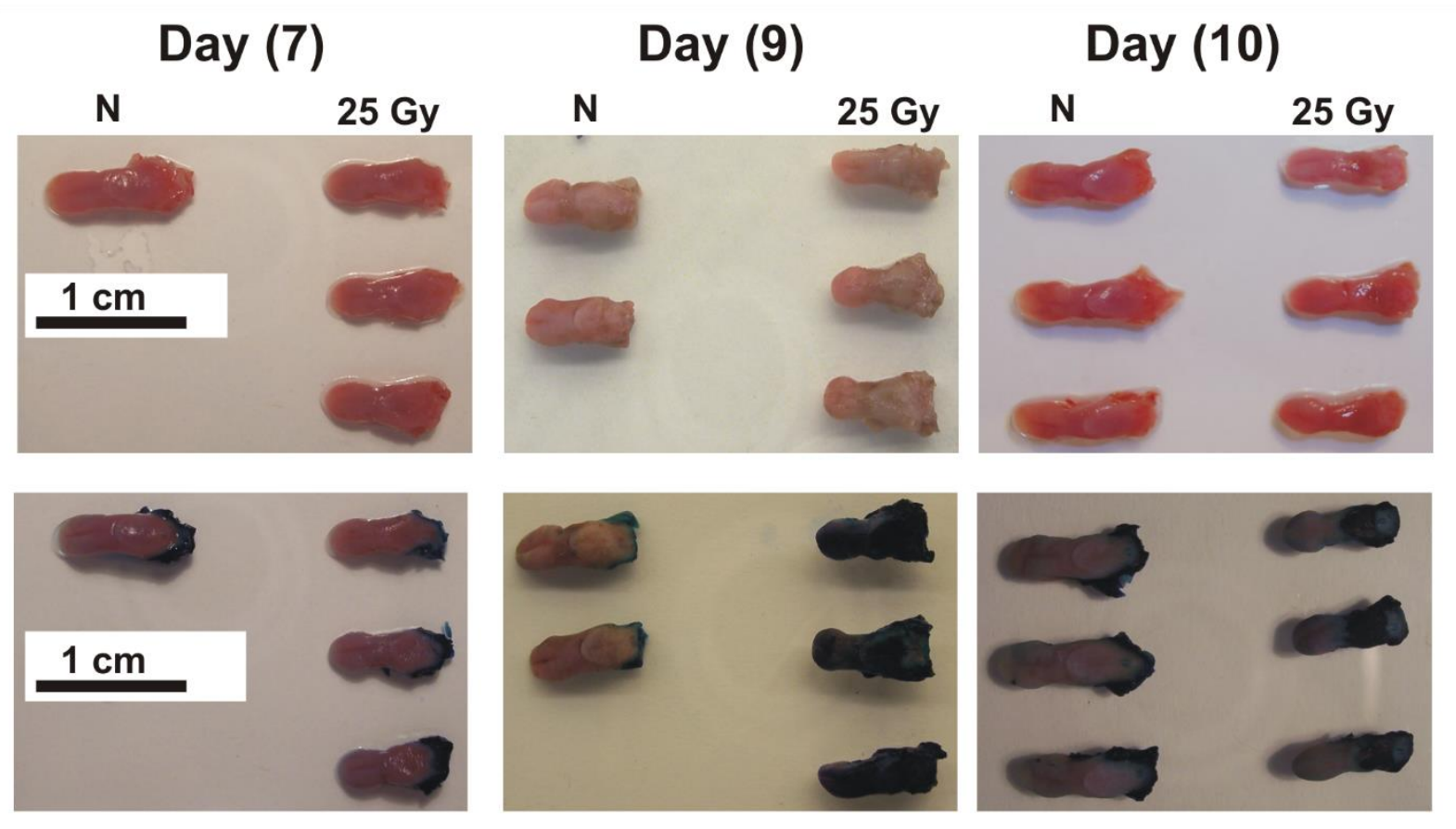

Figure.5.8.1.1.Supplemental: Lost intermolar eminence before physical ulcer appearance

25 Gy irradiated animals were sacrificed and tongue was dissected. Imaging was done before and after TB staining. Comparison was done between days 7, 9 and 10. Note the lost tongue eminence at day 7 with undetectable physical ulceration yet. Tongue shrinkage and volume reduction were always noted after irradiation. $(n=3)$. 
This page is intentionally left blank 
The next chapter represents our $3^{\text {rd }}$ manuscript showing our study to explore syngenic adipose mesenchymal stromal cells (aMSCs) therapeutic benefits in our previously generated radiation-induced oral mucositis (RIOM) mouse model in order to fulfil the following objectives:

1- Quantification of the therapeutic benefits of syngenic aMSCs therapy with clinically relevant and histological parameters.

2- Optimizing the following cellular therapy parameters:

a- The aMSCs therapy dose size

b- The dose number, and frequency

c- The time of onset

These parameters are thought to significantly achieve the best therapeutic gain.

3- Comparing frozen vs. freshly cultured aMSCs therapies. 


\section{Chapter 6 ADIPOSE MESENCHYMAL STROMAL CELLS}

\section{MINIMIZE \& REPAIR RADIATION-INDUCED ORAL MUCOSITIS}

Osama Muhammad Maria, MD, MSc ${ }^{1,2,3}$, Mostafa Shalaby4 , Alasdair Syme, $\mathrm{PhD}^{3,5,7}$, Nicoletta Eliopoulos, $\mathrm{PhD}^{2,6}$ and Thierry Muanza, MD, MSc ${ }^{1,3,6,7}$

1 Experimental Medicine Department, Faculty of Medicine, McGill University, Montreal, Quebec, Canada

2 Surgery Department, Faculty of Medicine, McGill University, Montreal, Quebec, Canada

3 Radiation Oncology Department, Jewish General Hospital, McGill University, Montreal, Quebec, Canada

4 Dawson College, Montreal, Quebec, Canada

5 Medical Physics Unit, McGill University, Montreal, Quebec, Canada

6 Lady Davis Institute for Medical Research, Jewish General Hospital, McGill University, Montreal, Quebec, Canada

7 Oncology Department, McGill University, Montreal, Quebec, Canada

\section{AUTHOR CONTRIBUTIONS}

- Osama Maria: Conception and design, collection and/or assembly of data, data analysis and interpretation, manuscript writing, final approval of manuscript.

- Mostafa Shalaby: Collection and/or assembly of data, Data analysis and interpretation 
- Alasdair Syme: Conception and design

- Nicoletta Eliopoulos: Conception and design, provision of study material, data analysis and interpretation, final approval of manuscript.

- Thierry Muanza: Conception and design, financial support, provision of study material, data analysis and interpretation, final approval of manuscript.

\author{
THE CORRESPONDING AUTHOR \\ Dr. Thierry Muanza, MD MSc FRCPC \\ Radiation Oncology Translational Research Lab, \\ Department of Radiation Oncology, \\ Jewish General Hospital and Lady Davis Institute Research Centre, \\ McGill University, \\ 3755 Côte-St.-Catherine Road, Suite G002, \\ Montréal, Québec, \\ Canada, H3T 1E2 \\ Tel: +1 (514)-340-8288, \\ Fax: + 1 (514)-340-7548, \\ Email:tmuanza@yahoo.com
}

Disclaimer : none 


\subsection{ABSTRACT}

Background: Mesenchymal stromal/stem cells (MSCs) have been used to repair and minimize radiation-induced normal tissue injury in the intestine, salivary gland, liver, skin, lungs, and cardiac muscle. We will investigate adipose tissue-derived MSCs (aMSCs) to minimize and/or repair single dose radiation-induced oral mucositis (RIOM).

Methods: We generated a single dose RIOM mouse model in male BALB/c mice. BALB/c aMSCs were isolated and characterized for functionality and phenotype. Syngenic aMSCs were implanted intraperitoneally at concentrations of $1,2.5,5,9$, and 10 million cells/dose with different dosing protocols. RIOM tongue ulceration was quantified macroscopically, microscopically, and by using different histological and clinically relevant parameters.

Results: 18 Gy irradiation generated a self-resolved single dose RIOM BALB/c male mouse model with a mean duration of $5.6 \pm 0.3$ days, $95 \%$ confidence interval of 4.233 7.1 days, and with $100 \%$ survival rate. 5 doses of 2.5 million functionally and phenotypically verified and freshly cultured syngenic aMSCs cells implanted intraperitoneally significantly and reproducibly reduced the RIOM ulcer duration to $1.6 \pm$ 0.3 days ( $95 \%$ confidence interval of $0.0233-3.1$ days, $72 \%$ reduction in RIOM ulcer duration), ulcer size, and ulcer floor epithelial height (eminence epithelium). The therapeutic benefits of syngenic freshly isolated aMSCs therapy were significantly dependent on, dose size and frequency, number of doses, and the therapy onset time. Syngenic freshly isolated aMSCs significantly minimized the RIOM-related weight loss, accelerated the weight gain, and improved irradiated animals' hydration and nutritional status. aMSCs therapy did not potentiate Head and Neck cancer in-vitro. 
Discussion and conclusion: Syngenic freshly cultured aMSCs significantly minimized and repaired radiation-induced oral mucositis in mice with $72 \%$ reduction in ulcer duration. aMSCs dose size and frequency, number of doses and therapy onset time are the main parameters that affected the therapy outcome. aMSCs did not accelerate Head and Neck cancer in-vitro. The anti-inflammatory properties of aMSCs will be investigated in future studies to highlight the main mechanistic pathways responsible for such significant therapeutic benefits. 


\section{KEYWORDS}

Adipose Mesenchymal Stromal/Stem Cells, Anti-inflammatory, Epithelium, Hydration Inflammation, Normal Tissue Injury, Radiation-Induced Oral Mucositis, Radiation Therapy, Tongue, Weight Loss 


\subsection{INTRODUCTION}

Radiation-induced oral mucositis (RIOM) is a normal tissue injury side effect of radiation (RT) therapy in Head and Neck cancer patients with a $100 \%$ incidence in altered fractionation radiotherapy $[1,2]$. RIOM is a form of four phase's mucosal barrier injury that is considered one of the major dose-limiting toxicities $[3,4]$. It is a challenge that leads to alteration in RT dose fractionation, treatment interruptions, and poor local tumor control with such narrow therapeutic ratio. RIOM starts as localized asymptomatic inflammatory hyperemia and edema, and then ends by confluent desquamation, necrosis and deep ulceration with exposed oral connective tissue that might lead to secondary infection. Although considered a self-limited inflammation if the patient survived, RIOM could lead to lethal deterioration of patient's quality of life in elderly sick patients with altered fractionation $\mathrm{RT}[1,5,6]$.

Reducing the severity and the duration of RIOM are the two main goals for a proposed treatment. Many therapies have tried to minimize and/or repair RIOM using topical and systemic routes. Although pharmacological and non-pharmacological therapies and procedures have been applied for RIOM, no single therapy has been identified to significantly minimize and/or repair RIOM mainly by reducing the injury severity and duration $[2,4,5,12,14-47]$. The recent clinical data on mesenchymal stromal/stem cells (MSCs) therapy in ionizing radiation-induced normal injury other than RIOM; e.g. bone, lung, intestine, and skin injury, showed promising therapeutic benefits. MSCs therapy helped in regenerating hematopoiesis and osteoradionecrosis, improving breathing parameters and lung immune function, improving intestinal mucosal inflammation, hemorrhages, fistulization, pain and diarrhea, and regenerated skin ulceration [71]. 
Adipose tissue-derived mesenchymal stromal/stem cells (aMSCs) are multipotent progenitor cells located in the stromal vascular fraction (SVF) of adipose tissue [74]. They are characterized by expressing MSCs-expected surface antigens Sca1, CD106, CD105, CD73, CD29 and CD44, and lacking the expression of hematopoietic stem cells (HSCs) surface antigens (e.g. CD11b and CD45) [74-76]. In addition to their multilineage differentiation potential, aMSCs have anti-inflammatory/immune-modulatory and paracrine effects [55-60]. They also have the ability to home to the site of tissue injury after irradiation and inflammation $[74,77,78]$. aMSCs are promising for cellular therapies due to their prominent anti-inflammatory effects, enhancing IL-10 secretion, ease of isolation, high cell count after expansion, as well as their source abundance [73]. In radiation-induced normal tissue injury, aMSCs have shown significant repair of cutaneous radiation syndrome [79-83] and photo-aging [84], RT-induced acute salivary gland [85] and intestine injuries [70, 86-88], and chronic injuries induced by radiotherapy $[80,89]$. In addition, we have shown in a previous study that aMSCs are relatively resistant to ionizing radiation, a property that qualifies them to be a reliable cellular therapy candidate before and during RT [159].

An initial MSCs therapy for RIOM conducted in 2014 by Schmidt et al. concluded that transplantation of bone marrow (BM) or BM-derived MSCs (bmMSCs) could modulate RIOM in fractionated RT depending on the time of transplantation [48]. Nevertheless, in another study they concluded that BM transplantation had no therapeutic effect on RIOM in single dose RT when compared to the therapeutic benefit of mobilization of endogenous BM stem cells [72]. In our present study, we investigated the ability of aMSCs therapy to minimize and/or repair the single dose RIOM. 


\subsection{MATERIALS AND METHODS}

\subsubsection{Isolation of mouse adipose tissue-derived MSCs (aMSCs)}

aMSCs were isolated according to our previous methodology in [159]. White adipose tissue of male BALB/c mice from Charles River Laboratories ${ }^{\circledR}$ (Montreal, QC, Canada) was sterilely collected, washed, minced and digested in 1X sterile PBS (Invitrogen ${ }^{\circledR}$ ), $2 \%$ heat-inactivated FBS (iFBS, Wisent ${ }^{\circledR}$, St-Bruno, QC, Canada) \& $2 \mathrm{mg} / \mathrm{mL}$ collagenase type II (Invitrogen ${ }^{\circledR}$, Burlington, ON, Canada) at $37^{\circ} \mathrm{C}$ for $15 \mathrm{~min}$. After filtration, the cell suspension was spun down and the cell pellet (Stromal Vascular Fraction, SVF) was re-suspended in $0.83 \%$ Ammonium Chloride $\left(\mathrm{NH}_{4} \mathrm{Cl}\right)$ for erythrocytes lysis. SVF Cells were plated in a $25 \mathrm{~mL}$ flask containing 1X Dulbecco's Modified Eagle's Media (DMEM, Invitrogen ${ }^{\circledR}$ ), 10\% iFBS (Wisent $\left.{ }^{\circledR}\right), 1 \%$ penicillin/streptomycin from Gibco ${ }^{\circledR}$ (distributed by Invitrogen Canada, Inc., Burlington, ON, Canada) at $37^{\circ} \mathrm{C} \& 5 \% \mathrm{CO}_{2}$ after counting and checking cell viability using Trypan blue. Medium was freshly supplemented with $2-20 \mathrm{ng} / \mathrm{mL}$ mouse Fibroblast Growth Factor-2 (FGF-2, Sigma-Aldrich ${ }^{\circledR}$ ) and $5 \mathrm{U} / \mathrm{mL}$ Sodium purified Heparin (SigmaAldrich $\left.^{\circledR}\right)$.

\subsection{2 aMSCs functional differentiation assay}

Mouse Mesenchymal Stem Cell Functional Differentiation Kit from R\& D Systems ${ }^{\circledR}$, Inc. (Minneapolis, MN, USA, Cat. \# SC010) was used for differentiation of aMSCs to adipocytes, osteocytes and chondrocytes according to the manufacturer's protocol. For adipogenesis, cells were seeded and cultured until $80 \%$ confluence. Then, media was replaced by $0.5 \mathrm{~mL}$ adipogenic differentiation media and kept in culture for 10-14 days. For osteogenesis, cells were seeded and cultured until 70\% confluence. Then, media 
was replaced by $0.5 \mathrm{~mL}$ osteogenesis differentiation medium and kept in culture for 1421 days. Both newly formed adipocytes and osteocytes were fixed with paraformaldehyde for immunohistochemistry (IHC) staining. For chondrogenesis, a cell pellet of $15 \times 10^{3}$ cells was kept in chondrogenic differentiation medium for 17-21 days. Then, the cell pellet was fixed with zinc formalin solution overnight, paraffin-embedded and sectioned. Antigen retrieval was done using the Universal Antigen Retrieval Reagent from R\&D Systems ${ }^{\circledR}$, Inc. (Cat.\# CTS015) before IHC.

\subsubsection{Immunohistochemistry (IHC) staining}

Cells and sections were washed, then blocked with $0.3 \%$ Triton X-100, 1\% BSA and $10 \%$ normal donkey serum in PBS for 45 min at room temperature. Cells were incubated at $4^{\circ} \mathrm{C}$ overnight with goat anti-mouse fatty acid binding protein-4 (FABP-4) primary antibody for adipocytes, goat anti-mouse osteopontin antibody for osteocytes, and sheep anti-mouse collagen-II antibody for chondrocytes. Antibodies were purchased from $R \& D$ Systems ${ }^{\circledR}$, Inc. After 3 washes, cells were incubated in the dark with diluted (1:200) NL557-conjugated donkey anti-goat secondary antibody (R\&D Systems ${ }^{\circledR}$, Inc., Cat. \# NL001) for 60 min at room temperature. Cells were washed 3 times and visualized with fluorescence microscope.

\subsubsection{Flow Cytometry (FC)}

Mouse Multipotent Stromal Cell Marker Antibody Panel from R\&D System ${ }^{\circledR}$, Inc. (Cat.\# SC018) was used for validation of aMSCs according to the manufacturer's protocol. In short, aMSCs cultured in a-MEM or DMEM supplemented with $10 \%$ Penicillin/Streptomycin and 1\% FBS were harvested freshly. Cells were resuspended in FC staining buffer at a concentration of $1 \times 10^{6}$ cells / $\mathrm{ml}$. For each MSCs marker 
antibody, $90 \mu \mathrm{L}$ of cell suspension was mixed with $10 \mu \mathrm{L}$ of each antibody of $100 \mu \mathrm{g} / \mathrm{mL}$ concentration and incubated for $30 \mathrm{~min}$ at $4^{\circ} \mathrm{C}$. After incubation and washing, cells were resuspended in $200 \mu \mathrm{L}$ of the buffer including $10 \mu \mathrm{L}$ of goat $\mathrm{F}(\mathrm{ab}$ ')2 anti-rat IgG-FITC (Cat.\# F0104B, from R\&D System ${ }^{\circledR}$, Inc.) for 30 min at $4^{\circ} \mathrm{C}$ in the dark. Cells were washed and resuspended in $200 \mu \mathrm{L}$ buffer for FC analysis using a BD FACS-Calibur ${ }^{\circledR}$ machine (BD Immunocytometry systems, San Jose, CA). For cells-specific surface antigens, we investigated Sca1, CD106, CD105, CD73, CD29, CD44 for MSCs expected antigens, and CD11b and CD45 for hematopoietic stem cell (HSCs) expected antigens.

\subsubsection{Syngenic aMSCs therapy}

aMSCs from passage 5 to 10 were used in the experiments. aMSCs were cultured in DMEM enriched with 10\% FBS and 1\% Penicillin/Streptomycin for at least 48 hours prior to use. Cells were then trypsinized, washed twice with serum free DMEM, and suspended in different concentrations ranging from 1 to $10 \times 10^{6}$ cells / dose in a final volume of $550 \mu \mathrm{l}$ per $1 \mathrm{ml}$ syringe with $23 \mathrm{G}$ needle. The intraperitoneal (IP) route was used for cell delivery into animals at different time points as indicated for each experiment before and after RT. In some experiments, frozen cells were thawed, washed twice with serum-free DMEM and used for therapy.

\subsection{6 aMSCs conditioned media collection}

$2 \times 10^{6}$ aMSCs were plated in $75 \mathrm{ml}$ flasks within a-MEM and DMEM media supplemented with 10\% Penicillin/Streptomycin and 1\% FBS. The conditioned media was collected after 24, 48 and 72 hours, and spun down to get rid of floating cells. Supernatant was placed into new falcon tubes and frozen at $-80^{\circ} \mathrm{C}$ until the time of use. 


\subsubsection{Single dose RIOM mouse model}

Animal handling was done according to McGill University's Standard Operating Procedures (SOPs) and the Canadian Council of Animal Care (CCAC). Generation of single dose RIOM was done using Gulmay ${ }^{\circledR}$ orthovoltage X-ray D3225 irradiator (Suwanee, GA, USA) according to the following protocol. Average $25 \mathrm{gm}$ weighted 10 week-old male BALB/c mice were anaesthetized by Ketamine/Xylazine/Acepromazine anesthesia, $0.05-0.1 \mathrm{~mL} / 10 \mathrm{gm}$ intraperitoneally, and protective ophthalmic ointment (natural tears) was applied (according to McGill University SOP-110). Then, animals were placed in the prone position touching and along the borders of a $20 \times 20 \mathrm{~cm}$ square cone in a position that only allows the animal head to be irradiated (area from the mid-coronal plan of the ear to the tip of the nose was underneath the edge of the cone assuring that the whole tongue was irradiated). We used an energy of $120 \mathrm{kVp}$ and a central output of $115.8 \mathrm{cGy} / 100 \mathrm{MU}$. Ionization chamber measurements were performed to quantify the dose rate near the edge of the cone where the mouse head was located. We delivered 18 Gy to induce RIOM. Animals were always kept on warm blankets to avoid hypothermia. After irradiation, animals were kept in $33^{\circ} \mathrm{C}$ incubator for 2 hours with subcutaneous hydration ( $1 \mathrm{~mL} 0.9 \%$ saline subcutaneously / 6 hours for 24 hours) until complete recovery. Animals were moved to their cages with free access to enriched jelly food (Bio-Serv ${ }^{\circledR}$ Rodent Liquid Diet, AIN-76 served with 15\% w/v gelatin) and water with daily observation. The primary and clinically relevant end-point was established as grade 3 RIOM by RTOG/EORTC scale, Version.2. 


\subsubsection{Tissue collection and processing}

At different time points (indicated for each experiment), animals were put to sleep with Isoflurane inhalation (Oxygen flow of $0.4-0.8 \mathrm{~L} / \mathrm{min}$, and $2.5 \%$ Isoflurane vapor maintenance) for total blood collection by cardiac puncture. Collected blood was slowly evacuated into iced $3.5 \mathrm{mg}$ K2 EDTA sprayed and dried BD Vacutainer ${ }^{\circledast}$ Plus plastic whole blood tube (Lavender BD Hemogard ${ }^{\mathrm{TM}}$ closure, cat. \# 367841) for serum collection. Serum aliquots were kept frozen until time of analysis. After cervical dislocation, complete tongue tissue was carefully dissected and put immediately into cold 1X PBS. Sometimes, salivary glands, liver and spleen were collected in 1x PBS. Tongue was stained with $1 \%$ toluidine blue (TB) in $10 \%$ acetic acid. Repeated wiping with acetic acid soaked gauze was applied until no more dye recovery from the tissue [1]. After macroscopical analysis of RIOM, tongue tissue was dissected longitudinally in the median plan (dividing the ulcer into identical halves), kept in $10 \%$ buffered formalin, then tissue was paraffin embedded and $3 \mu \mathrm{M}$ sections were made for $\mathrm{H} \& \mathrm{E}$ staining and microscopic analysis. Many clinically relevant and histological parameters for quantification of RIOM could be applied, e.g. ulcer size and ulcer size \% (ulcer size/total tongue epithelialized upper surface by Image ${ }^{\circledR}$ surface area by pixel number), ulcer duration, ulcer time-to-appear (latency), ulcer time-to-heal, posterior upper surface epithelium height (intermolar eminence epithelium height) and cellularity (infiltrating cells) were used to quantify the therapeutic gain. Salivary glands were also collected for comparison. 


\subsubsection{Determination of cell survival}

Human Head and Neck cancer cell line (hypopharyngeal squamous cell carcinoma, FaDu, from ATCC ${ }^{\circledR}$ \# HTB-43 ${ }^{\text {TM }}$ ) was purchased and expanded in a-MEM with $10 \%$ Penicillin/Streptomycin and 1\% FBS. Cell sensitivity to RT was measured by clonogenic assay $(C A)$ as we previously published [177]. FaDu cells were plated in 6 well plastic plates at plating densities of 100, 200, 400, 600 and 800 cells/well for IR doses of 0,2, 4, 6 and $8 \mathrm{~Gy}$, respectively, using $18 \mathrm{MV}$ photons of a Varian ${ }^{\circledR} 21 \mathrm{EX}$ linear accelerator (Palo Alto, CA, USA). Cells were irradiated 24 hours after plating. Old media was removed and replaced by $2 \mathrm{~mL} /$ well of aMSCs conditioned media (DMEM and $\alpha-M E M)$. Colonies were counted 10 days after culture at $37^{\circ} \mathrm{C}$ and $5 \% \mathrm{CO}_{2}$ incubator.

\subsubsection{In-vivo aMSCs imaging}

PKH26-Red (Sigm-Aldrich, \# MINI26) cell membrane lipophylic tracker is provided as $100 \mu \mathrm{l}$ of $1 \mathrm{mM}$ concentration to be diluted in Diluent- $\mathrm{C}$ according to the manufacturer's protocol. We decided, based on previous experiments, to use $40 \mu \mathrm{M}$ final concentration of the dye for aMSCs labeling. Final volume of the injected cells / animal was $500 \mu \mathrm{l}$. We used $23 \mathrm{G}$ needle in order to deliver exactly $500 \mu \mathrm{l}$ (12.5 million cells) single shot intraperitoneally to the animal. Dye was prepared immediately before use. The dye was inculcated with the cells 1-5 min at room temperature with frequent pipetting up and down / 1 min. Reaction was stopped by adding $10 \mathrm{ml}$ of $1 \%$ BSA DMEM. Cells were spun down at $400 \mathrm{G}$ for $10 \mathrm{~min}$ at room temperature, then washed with $1 \%$ BSA DMEM followed by 2 washes in serum-free DMEM. Cells were transferred to a new tube, then suspended in $500 \mu \mathrm{l}$ to be loaded into syringes prior to mice injection. Imaging was done using IVIS ${ }^{\circledR}$ Spectrum (PerkinEImer ${ }^{\mathrm{TM}}$ ) at different time points. 


\subsection{STATISTICS}

GraphPad Prism ${ }^{\circledR}$ software (version 5.01) was used for statistical analyses. Data were expressed as the mean $(\mathbf{M}) \pm$ the standard error of the mean (SEM). The paired twotailed Student's t-test was applied for two sets of data. P-value $<0.05$ was considered a significant difference.

\subsection{RESULTS}

\subsection{1 aMSCs maintained their stem cells functionality and phenotype}

We isolated, expanded, and characterized BALB/c mice-derived aMSCs. aMSCs were constantly able to successfully differentiate into fatty acid binding protein-4 (FABP-4)positive adipocytes showing their Oil-red-O-stained fat droplets, collagen-II positive chondrocytes showing their phenotype-specific Alcian-Blue-stained sulphated mucin and Neutral-Red-stained lysosymes, and osteopontin-positive osteocytes showing their Alizarin-Red-stained calcium deposits (Figure.6.5.1.I).

FC analysis of different batches of aMSCs showed that they were constantly expressing FITC-labeled surface antigens expected on MSCs (Sca1, CD106, CD73, CD29, CD44) when tested up to 7 days culture, with corresponding mean percentages of up to $70 \%$, $80 \%, 85 \%, 99.5 \%$, and $99 \%$ of FITC-positive cells, respectively. Isolated aMSCs were negative, as expected, for FITC-labeled HSC surface antigens (CD11b and CD45) with corresponding percentages of $1 \%$ for both. aMSCs cultured in $\alpha$-MEM or DMEM did not show significant difference in the expression percentages (Figure.6.5.1.II, and III). 
(A) BF

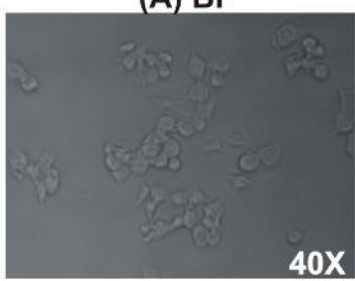

(D) BF

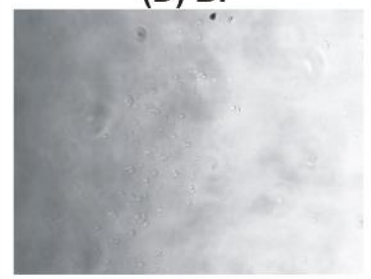

(G) BF

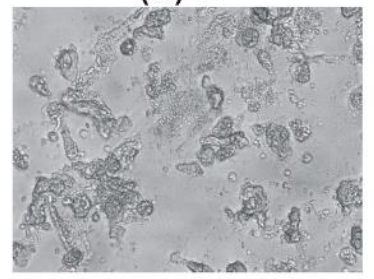

(B) FABP-4 +ve

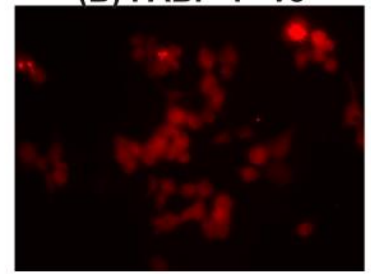

(E) Collagen-II +ve

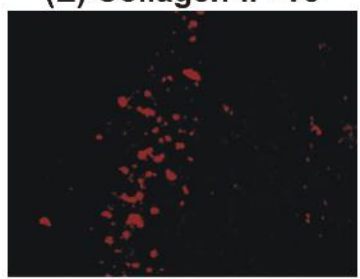

(H) Osteopontin +ve

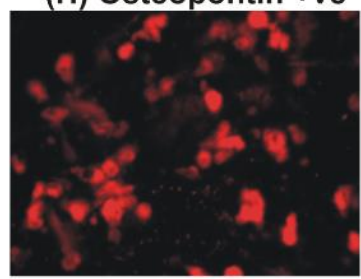

(C) Oil-Red-O

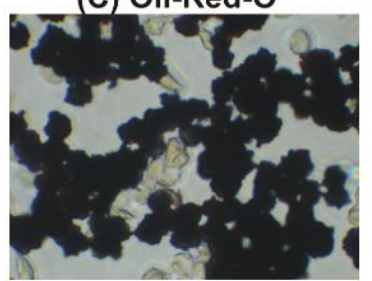

(F) Alcian-Blue/NR

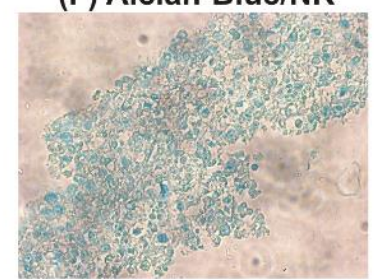

(I) Alizarin-Red

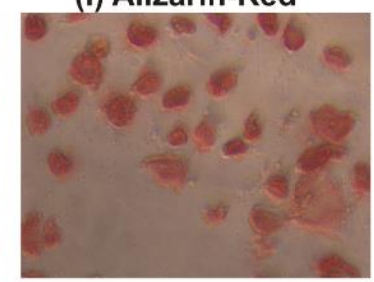

Figure.6.5.1: Functional and phenotypic characterization of aMSCs

Figure.6.5.1.I: Exponentially growing aMSCs were differentiated to adipocytes $(A, B, C)$, chondrocytes $(D, E, F)$, and osteocytes $(G, H, I)$. After 14-21 days, cells were fixed and saved for immunohistochemistry (IHC). (A) Represents the bright field (BF) image of the corresponding mouse fatty acid binding protein-4 (FABP-4)-positive newly formed adipocytes (red, FABP-4 +ve) shown in (B). (C) Represents the Oil-Red-O staining of the fat droplets inside newly formed adipocytes (dark red). (D) Represents the bight field (BF) image of the corresponding collagen-II positive (Collagen-II +ve) newly formed chondrocytes (red) shown in (E). (F) Represents the Alcian-Blue staining of sulphated mucin (blue) and Neutral Red (NR) staining of the lysozymes (red) inside newly formed chondrocytes. (G) Represents the bight field (BF) image of the corresponding osteopontin-positive newly formed osteocytes (red, Osteopontin +ve) shown in 
(H). (I) Represents the Alizarin-Red staining of calcium deposits inside newly formed osteocytes (red). Images magnification is 40X.

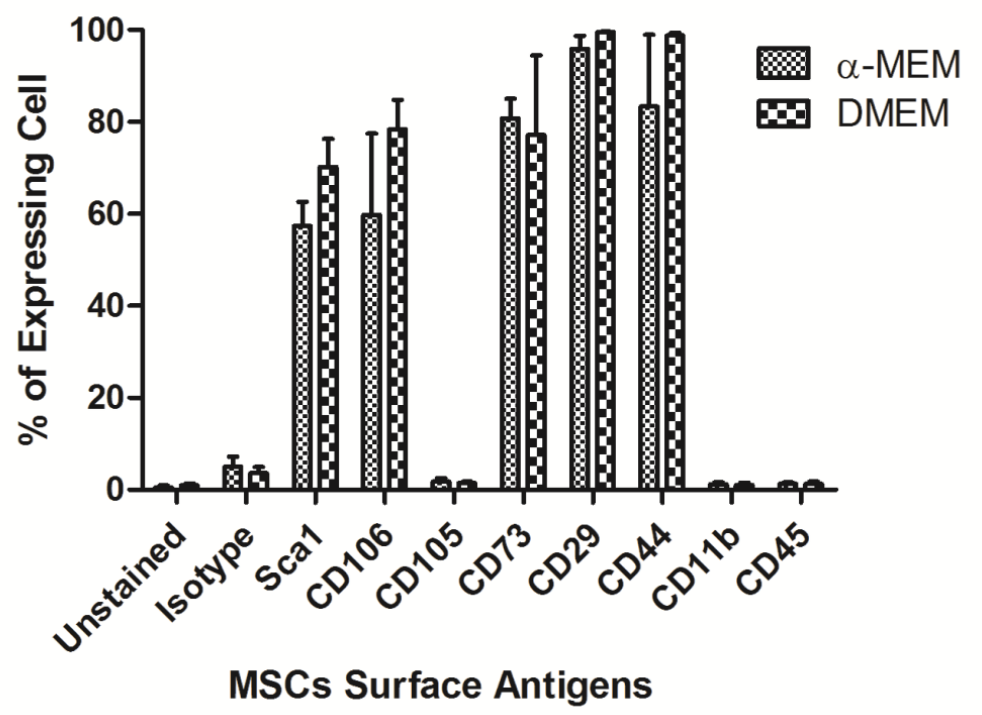

Figure.6.5.1.II: aMSCs were analyzed by flow cytometry (FC) after being cultured for 1-7 days in both DMEM and $\alpha-M E M$. We assessed the expression of surface antigens often seen on Mesenchymal Stromal/Stem Cells (MSCs), i.e. Sca1, CD106, CD105, CD73, CD29 \& CD44, as well as those absent on MSCs since typical of Hematopoietic Stem Cells (HSCs), i.e. CD11b and CD45, with the percentages of expressing cells shown on each panel. We used FITC-labeled antibodies for detecting the percentage of expressing cells. $(n=4)$, data presented as the mean \pm the standard error of the mean (SEM). 

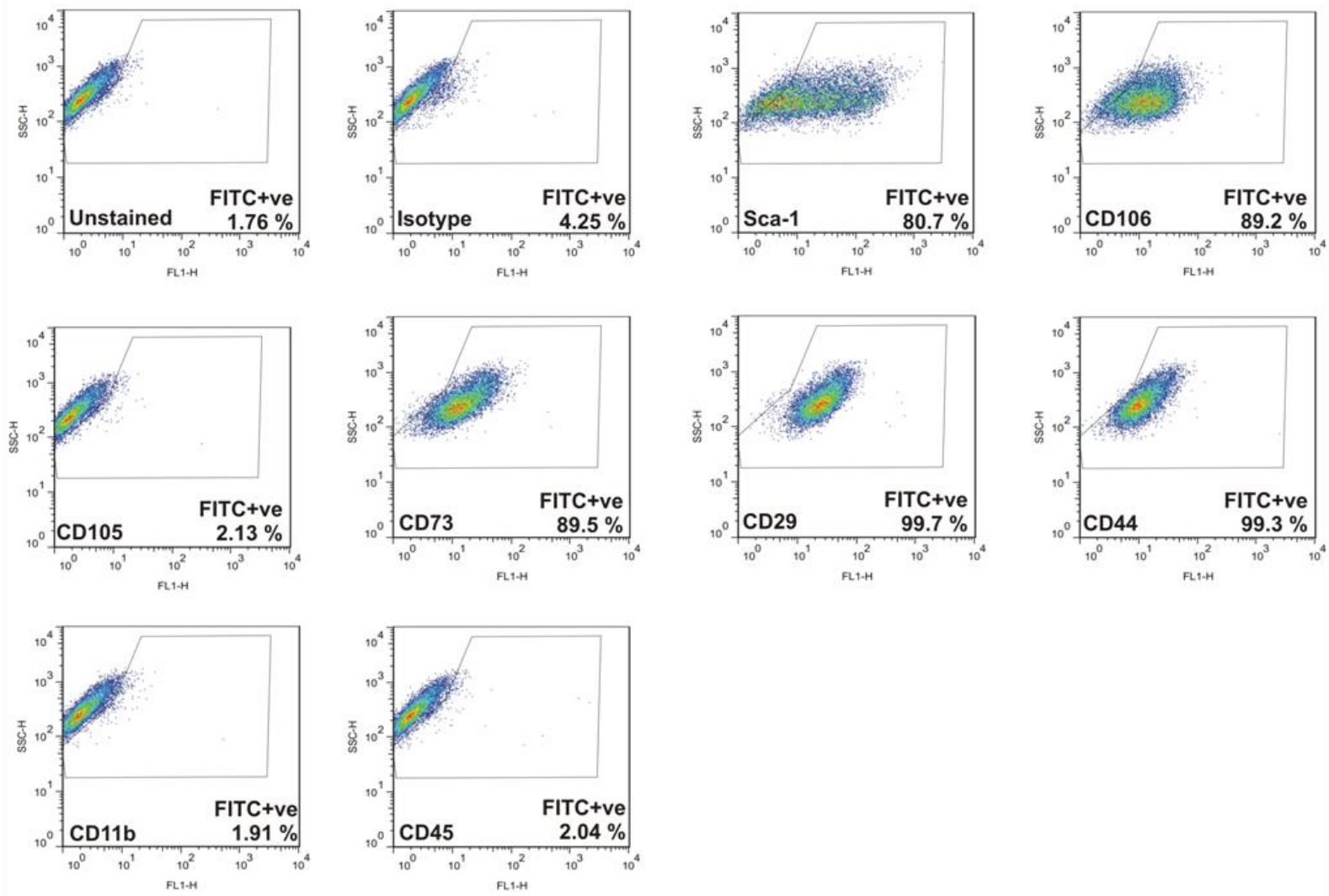

Figure.6.5.1.III: Represents analysis of one experiment showing the percentages of FITCpositive cells.

\subsubsection{Self-resolved single dose RIOM with $100 \%$ survival rate}

We were able to generate a self-resolved single dose RIOM BALB/c male mouse model. We quantified the results as the mean $(\mathbf{M}) \pm$ the standard error of the mean (SEM). With a single dose of 18 Gy, considering that the RT day is day 0 , we achieved a self-resolved RIOM ulceration of $5.6 \pm 0.3$ days duration $(95 \%$ confidence interval 4.233-7.1 days), ulcer time-to-appear (latency) at $(9.3) \pm 0.3$ days ( $95 \%$ confidence interval 7.867-10.733 days), and ulcer time-to-heal at (15) \pm 0.58 days ( $95 \%$ confidence interval 12.517-17.483 days) with $100 \%$ animal survival rate (Table.6.8.1.1 and 
6.8.1.2). The RIOM ulcer was always at the posterior dorsal surface of the tongue where the intermolar eminence is located anatomically, called posterior epithelium or eminence epithelium. After 18 Gy RT, animals showed ulcer mean size of $15 \%$ and $17 \%$ of the total epithelialized upper surface of the tongue at days 9 and 11 , respectively (Figure.6.5.3.B). RIOM animals showed significant reduction in the posterior upper surface epithelium height (intermoral eminence) that was recovered completely by day 21 with marked significant difference at days 9 and 12 (p-value < 0.0005) (Figure.6.5.2.D). At day 10, we measured less than $5 \mu \mathrm{m}$ epithelial heights in RIOM compared to a mean of $200 \mu \mathrm{m}$ height in normal animals (Figure.6.5.2.C). Beyond 18 Gy dose, mice could not survive due to severe ulceration and inflammation that resulted in uncorrectable weight loss and dehydration. Ulcer was always detectable and well stained macroscopically by $1 \%$ TB in deep blue coloration signifying the eroded epithelium. Ulcer size was dependent on the stage of the RIOM which resolved by day $15 \pm 0.58$ day, nevertheless, the epithelium was completely recovered to normal mean heights at day 21 after irradiation (Figure.6.5.2.B, D). Animal weight loss and gain were significant parameters for the severity, the degree and the stage of the RIOM. After RT, irradiated animals started to significantly lose weight which reached the minimum by days 13 and15, then started to gain weight to normal averages by day 21 (Figure.6.5.4.C). Decreased total tongue epithelialized upper surface area and the shrinkage noted in animal tongue and salivary glands after RT were reflecting the animal's nutritional and hydration status (Figure.6.5.2.A, D). We registered $100 \%$ survival of the RIOM in experiments with hydration of $1 \mathrm{~mL}$ of $0.9 \%$ saline subcutaneously / 6 hours for 24 hours. 
A
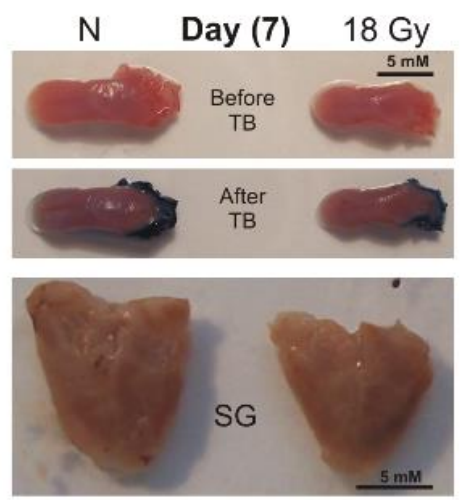

C

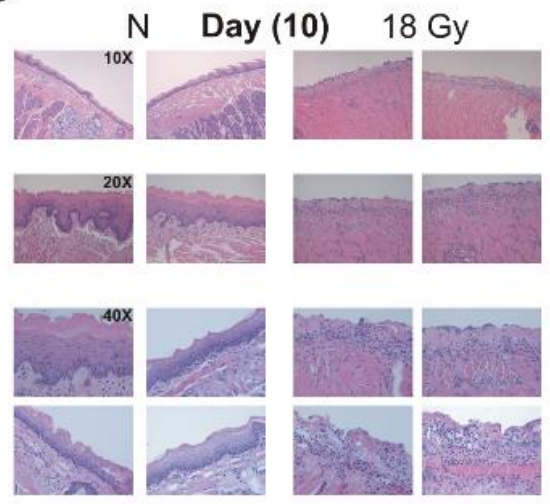

B
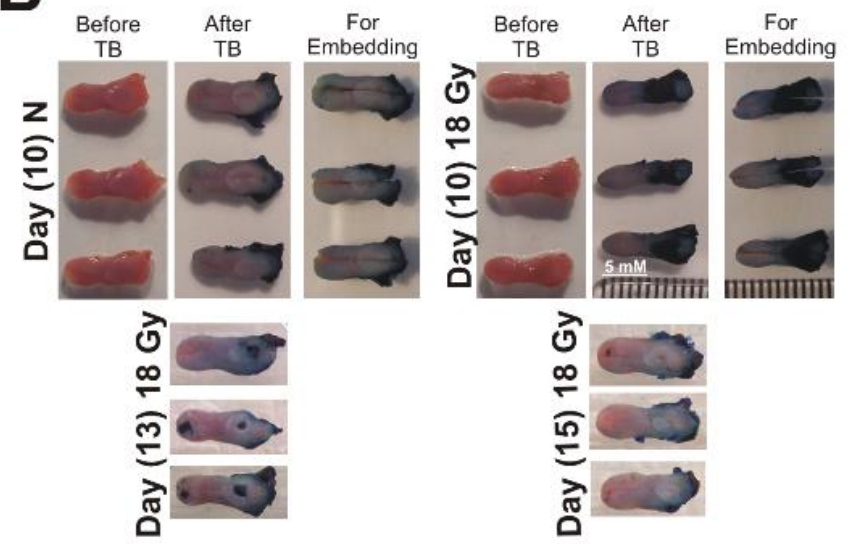

D

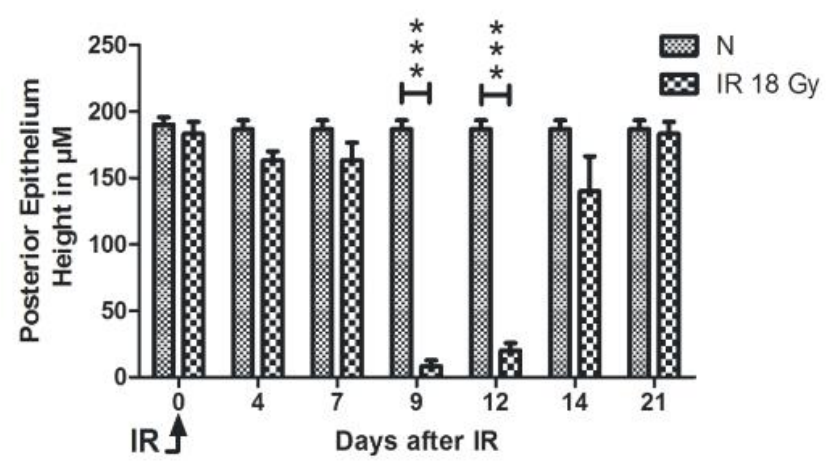

Figure.6.5.2: Self-resolved single dose RIOM with $100 \%$ survival rate

10 week-old male BALB/c mice were irradiated with 18 Gy at Day 0. After irradiation, animals were hydrated during the recovery period inside the incubator and afterwards, then were given free access to enriched soft diet and water. Mice were sacrificed, and tongues and salivary glands were collected. Tongues were immersed into $1 \%$ toluidine blue (TB) in $10 \%$ acetic acid in order to stain ulcerated areas (devoid of epithelium), then prepared for paraffin embedding by longitudinal dissection (A, B). (A) Is showing the shrinkage in size in both irradiated tongue and salivary glands that started before the physical detection of RIOM ulceration compared to nonirradiated animals (N). (B) Is showing the physical ulcer, its progression and the complete 
resolution by day 15. (C) Represents H\&E staining of the upper posterior tongue surface (intermolar eminence) with magnifications of 10X, 20X, and 40X. The latter was used for measuring the epithelial height in $\mu \mathrm{M}$. Hyper-cellularity is noted due to inflammatory cellular infiltration. (D) Represents the mean height of the eminence epithelium (posterior epithelium) at different time points comparing the irradiated and non-irradiated animal groups. 3 animals per group were used. $(\mathrm{n}=3),{ }^{* *}=\mathrm{P}$-value $<0.0005$ and data presented as the mean \pm the standard error of the mean (SEM).

\subsubsection{Syngenic aMSCs therapy minimized and repaired RIOM}

Syngenic aMSCs therapy was achieved by giving 2.5 million freshly cultured cells in 500 $\mu \mathrm{L}$ serum-free DMEM intraperitoneally for five doses at days $-1,1,3,5$, and 7 . The same protocol was followed with syngenic fibroblasts therapy. Our results showed that aMSCs therapy succeeded in causing marked delay of the onset and acceleration of the healing of RIOM, resulting in significantly shorter RIOM ulcer duration compared to both fibroblasts therapy and non-treated animal groups ( $p$-value $<0.005)$ (ulcer duration reduction of $72 \%$ from the non-treated RIOM ulcer duration). The RIOM ulcer duration was $1.3 \pm 0.3$ days $(\mathrm{M} \pm \mathrm{SEM})$ in aMSCs treated group compared to $5.6 \pm 0.3$ days in both fibroblasts treated and non-treated animal groups. RIOM ulcer-time-to-appear was at $11.3 \pm 0.9$ days after RT in aMSCs treated animal group compared to $9.3 \pm 0.3$ days in fibroblasts treated and non-treated animal groups. RIOM ulcer time-to-heal was at 13 \pm 0.58 days in aMSCs treated animals compared to $15 \pm 0.58$ days in fibroblasts treated and non-treated animal groups (Table.6.8.1.1 and 6.8.1.2) (Figure.6.5.3.D). aMSCs treated animals showed the smallest RIOM ulcer size at all tested time points (Days 9, $11,13,15)$ compared to those of fibroblast treated and non-treated animal groups 
(Figure.6.5.3.A). They also showed a significantly smaller ulcer size $\%$ to the total tongue epithelialized upper surface compared to non-treated animal groups at days 9 , and 13 ( $p$-values $<0.005$, and $<0.05$ respectively) (Figure.6.5.3.B). The aMSCs treated animal group showed marked higher upper posterior epithelium (intermolar eminence, ulcer floor epithelium), which was significant at days 9,13 , and 15, compared to nontreated animals groups ( $p$-value $<0.05,<0.005$, and $<0.0005$, respectively). There was a minimal therapeutic effect detected at day 15 in fibroblasts treated groups compared to non-treated group, however that was much inferior to that of aMSCs treated group (Figure.6.5.3.C). aMSCs were still detectable at the implantation site 14 days after implantation (Figure.6.5.3.F). 
A

Day (9)

Day (11)

Day (13)

Day (15)

Day (21)
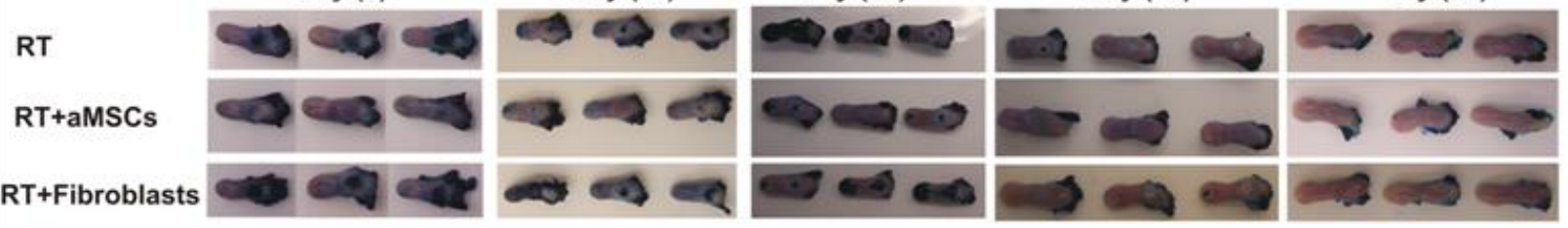

B

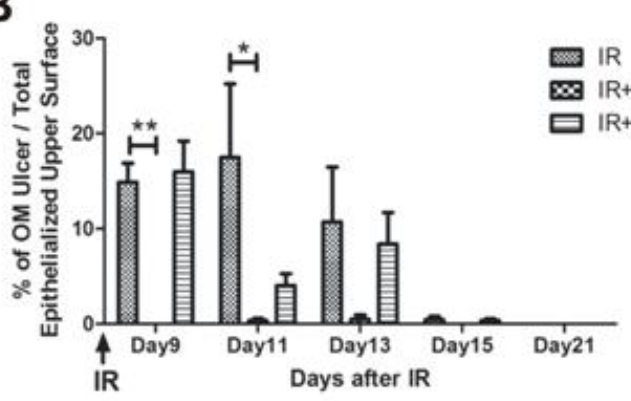

C

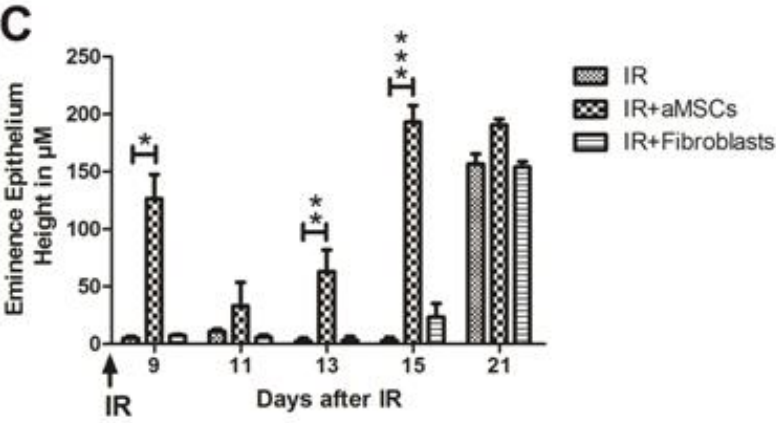

D

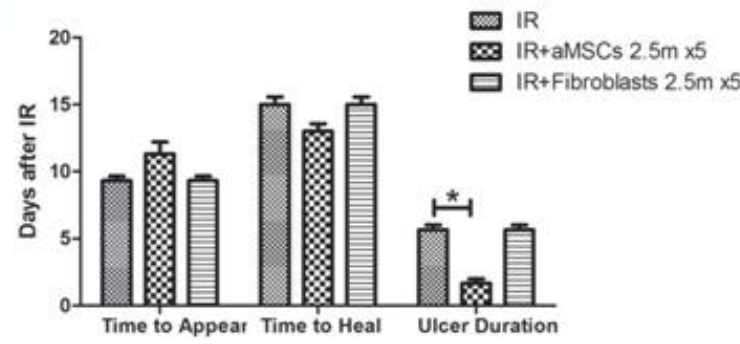

E
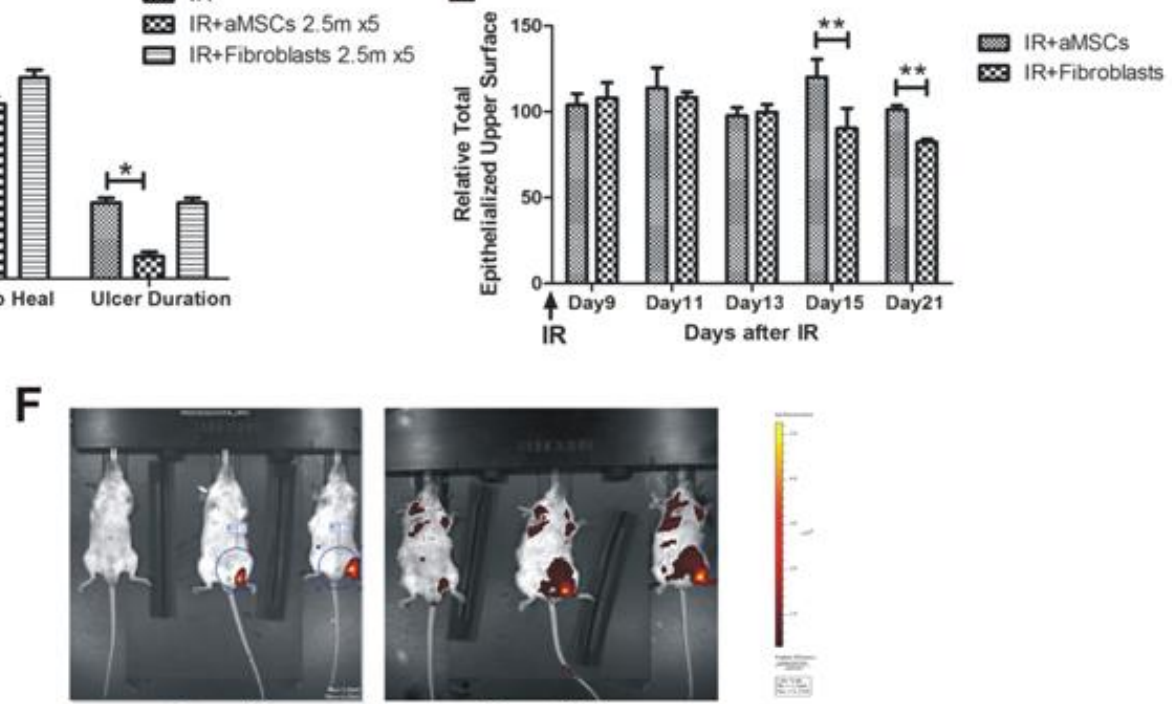

Day (6)

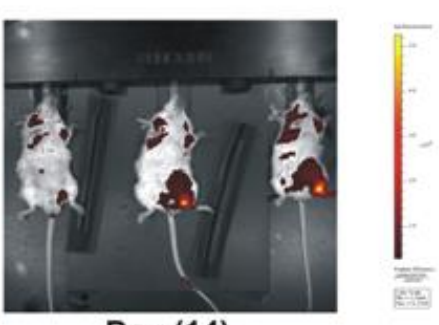

Day (14)

Figure.6.5.3: Syngenic freshly isolated aMSCs therapy minimized and repaired RIOM

10 week-old male BALB/c mice were irradiated with 18 Gy at Day (0). Animals were divided into 3 groups (3 animals/group/time point): irradiated only (IR), irradiated and aMSCs-treated (IR+aMSCs), and irradiated and fibroblasts-treated (IR+Fibroblasts) groups. 2.5 million of BALB/C freshly cultured aMSCs or fibroblasts were implanted intraperitoneally into the treatment group at days $-1,1,3,5$, and 7 . (A) Represents the TB-stained tongues at different time points after 
irradiation in days showing different stages of ulcer formation and resolution. (B) Represents the percentage of oral mucositis (OM) ulcer size of the total epithelialized upper surface of the tongue. (C) Represents the mean height of the ulcer floor epithelium (eminence epithelium height) in $\mu \mathrm{M}$ at different time points. (D) Represents the mean of: time-to-heal, time-to-appear, and ulcer duration in days for all experimental groups. (E) Represents the mean of the relative total epithelialized upper surface of the tongue in all experimental groups, (relative = epithelium surface area in treated group/non-treated group). (F) Represents the in-vivo imaging of a single dose of 12.5 million aMSCs cells implanted intraperitoneally into 18 Gy irradiated mice. aMSCs were imaged immediately after irradiation and every other day until day (14) after implantation. $(n=3),{ }^{*}=$ P-value $<0.05,{ }^{* *}=P$-value $<0.005,{ }^{* * *}=$ P-value $<0.0005$, and data presented as the mean \pm the standard error of the mean (SEM).

\subsubsection{Syngenic aMSCs therapeutic benefits depend on dose size and frequency, number of doses, and the therapy onset time relative to the RT exposure}

Three doses of 10 million freshly isolated aMSCs injected intraperitoneally at days 0,3 , and 7 [triple dose protocol] significantly showed the smallest RIOM ulcer size \% to the total epithelialized upper surface of the animal tongue and shortest RIOM ulcer duration compared to controls and to the same dose given once at day 0 [single dose protocol] or twice at days 0 , and 3 [double dose protocol] ( $p$-values $<0.005,0.00005,0.0005$, and 0.0005 at days $9,11,13$, and 15, respectively) (Figure.6.5.4.A). Nevertheless, we documented significant clinically relevant improvement in ulcer size \% with single and double dose protocols which were as high as that of the triple dosing protocol. In 
addition, the triple dosing protocol showed significantly higher posterior epithelium (eminence epithelium) at day 13 when compared to the non-treated animal group ( $p$ value $<0.0005)$ (Figure.6.5.4.B).

When aMSCs therapy was started before RT within the five dose protocol (at days -1 , in addition to doses at days $1,3,5$, and 7 ) while comparing the effect of dose size of 1 , 2.5 , and 5 million frozen cells delivered intraperitoneally, we discovered that the 2.5 million cell dose size yielded the significantly best therapeutic effect on RIOM ulcer. We recorded clinically relevant ulcer parameters macroscopically and microscopically, e.g. the smallest ulcer size \%, the longest upper posterior epithelium, and the shortest ulcer duration that was evident with 2.5 million cell dose size (Figure.6.5.4.D, E, F). Increasing the dose size beyond 2.5 million cells showed significant improvement in the therapeutic benefits. However, such improvement was still inferior to that of the dose size of 2.5 million cells in the overall parameters (Figure.6.5.4.C, D). We also noted that a dose size of 5 million of freshly cultured cells significantly showed the largest relative total epithelialized upper surface area of the animal tongue, reflecting the best hydration and nutritional status of the animal when compared to frozen cells with the same dose size ( $p$-value $<0.05,0.0005,0.05$, and 0.005 for days $8,10,12$, and 14 after RT exposure, respectively) (Figure.6.5.3.E\& Figure 6.5.4.E). Freshly cultured aMSCs (5 million cells / dose for 5 doses) significantly produced the highest ulcer floor epithelium maintained for the longest period (from day 10 to day 14 ) ( $p$-value $<0.005,0.05$, and 0.005 for days 10, 12, and 14 after RT exposure, respectively) (Figure.6.4.5.D). 

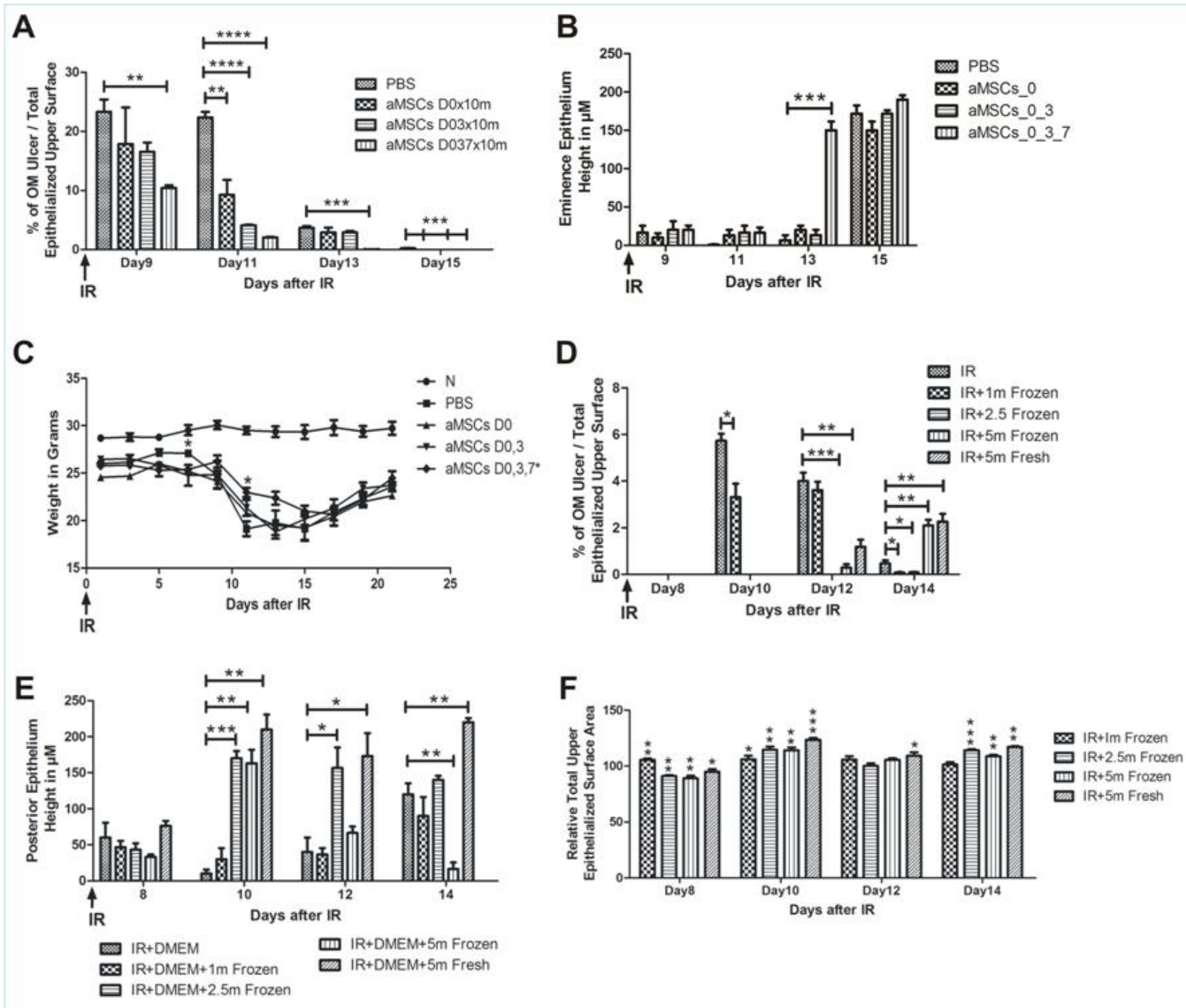

Figure.6.5.4: Syngenic aMSCs therapeutic benefits depend on dose size, time of onset, and dosing frequency

10 week-old male BALB/c mice were irradiated with 18 Gy at Day 0. Animals were divided into 4 groups (3 animals/group/time point): PBS-treated and 3 aMSCs-treated groups. 10 million of BALB/c freshly cultured aMSCs were implanted intraperitoneally into the 3 treatment groups at day 0 only [aMSCs D0x10m], days 0 and 3 [aMSCs D03x10m], and days 0,3 , and 7 [aMSCs D037x10m]. (A) Represents the mean of the percentage of ulcer size to the total epithelialized upper surface of the tongue. (B) Represents the mean height of the ulcer floor (eminence 
epithelium height) in $\mu \mathrm{M}$. (C) Represents the mean weight, in grams, of animals up to 21 days after irradiation in non-irradiated (N) vs PBS and aMSCs treated groups.

In another experiment, $18 \mathrm{~Gy}$ irradiated animals were divided into 5 groups (3 animals/group/time point): irradiation only group (IR) and 4 irradiation-with-aMSCs groups.

aMSCs were implanted intraperitoneally at days $-1,1,3,5$, and 7 with the following dose sizes: 1 , 2.5, 5 million thawed frozen cells and 5 million freshly cultured cells. (D) Represents the mean of the percentage of ulcer size to the total epithelialized upper surface of the tongue. (E) Represents the mean height of the ulcer floor (posterior epithelium height) in $\mu \mathrm{M}$. (F) Represents the mean of the relative total epithelialized upper surface of the tongue in all experimental groups, (relative $=$ epithelium surface area in treated group/non-treated group). $(n=3), *=P$ value $<0.05,{ }^{* *}=\mathrm{P}$-value $<0.005,{ }^{* * *}=\mathrm{P}$-value $<0.0005,{ }^{* * * *}=\mathrm{P}$-value $<0.00005$ and data presented as the mean \pm the standard error of the mean (SEM).

\subsection{5 aMSCs therapy improved RIOM side effects}

We noted before that, the animal group treated with 5 doses of freshly cultured aMSCs had marked larger relative total tongue epithelialized upper surface with significant difference noted at days 15, and 21 after RT (P-value $<0.005)$ compared to that of the fibroblasts treated group. This reflects the significant improvement of animal hydration status in aMSCs treated group (Figure.6.5.3.E). We also noted that a single dose of 9 million cells showed only a significant weight gain at day 15 after RT (Figure.6.5.5.A). However, the triple dosing protocol significantly showed a lesser weight loss at day 11 $(P$-value $<0.05)$ compared to the single and double protocol (Figure.6.5.4.B). Finally, we recorded that the animal group treated with 5 doses of freshly cultured aMSCs (2.5 
million cell dose size, 5 doses protocol) did not only show a significant lesser weight loss but also a significant faster and higher weight gain compared to the non-treated animal group ( $p$-value $<0.05)$ (Figure $6.5 .5 . C)$.
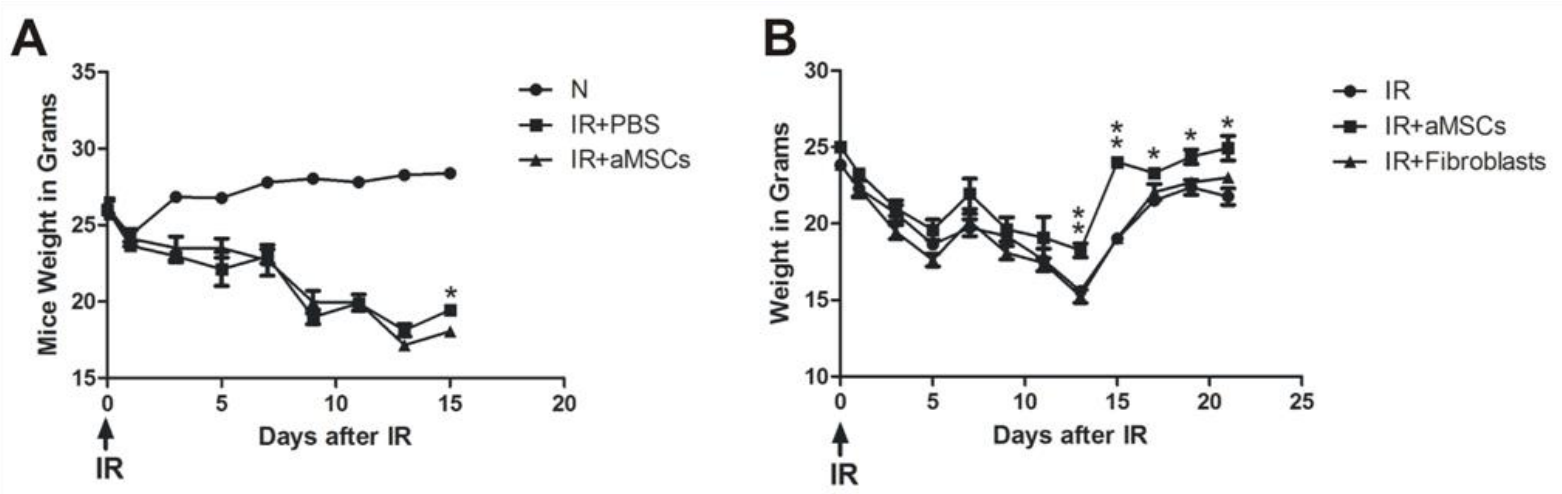

Figure.6.5.5: aMSCs therapy improves RIOM side effects

(A) 10 week-old male BALB/c mice were irradiated with 18 Gy at Day 0. Animals were divided into 3 groups (3 animals/group/time point): non-treated, PBS-treated, and aMSCs-treated groups. A single dose of 9 million of BALB/c freshly cultured aMSCs were implanted intraperitoneally at day 7 . The mean weight of all experimental groups at different time points is showed.

(B) 10 week-old male BALB/c mice were irradiated with 18 Gy at Day (0). Animals were divided into 3 groups ( 3 animals/group/time point): irradiated only (IR), irradiated and aMSCs-treated (IR+aMSCs), and irradiated and fibroblasts-treated (IR+Fibroblasts) groups. 2.5 million BALB/C freshly cultured aMSCs or fibroblasts were implanted intraperitoneally into the treatment groups at days $-1,1,3,5$, and 7 . The mean weight of animals at different time points is showed. $(n=3), *$ $=$ P-value $<0.05$, and ${ }^{* *}=\mathrm{P}$-value $<0.005$, and data presented as the mean \pm the standard error of the mean (SEM). 


\subsection{6 aMSCs do not potentiate Head and Neck cancer cells in-vitro}

aMSCs conditioned media collected from 2.5 million cells 24,48 , and 72 hours after

culture onset time did not increase the survival fraction or the platting efficiency of FaDu hypopharyngeal carcinoma cells cultured in $\alpha$-MEM or DMEM media after being irradiated with 0, 2, 4, 6, and 8 Gy (Figure.6.5.6).

A

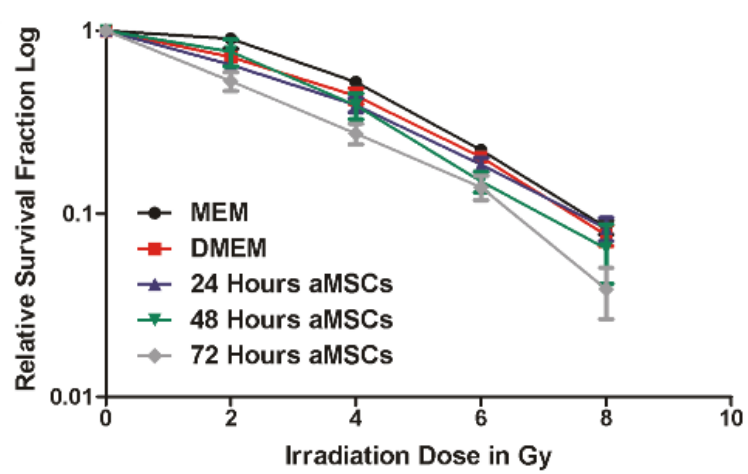

C

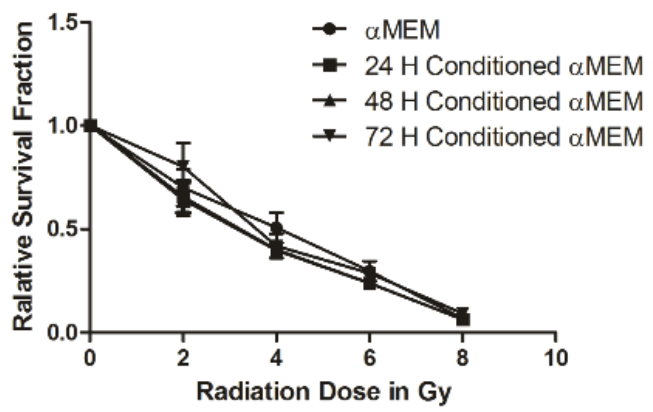

B

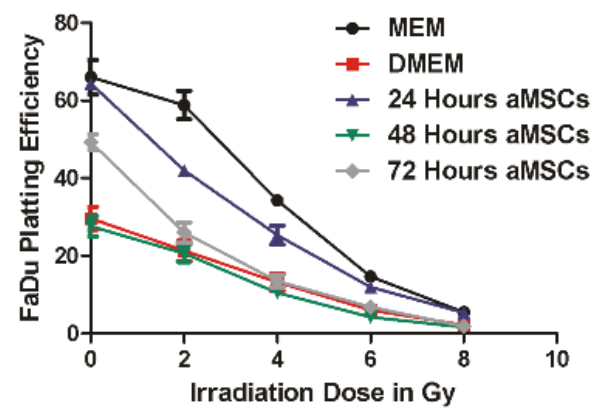

D

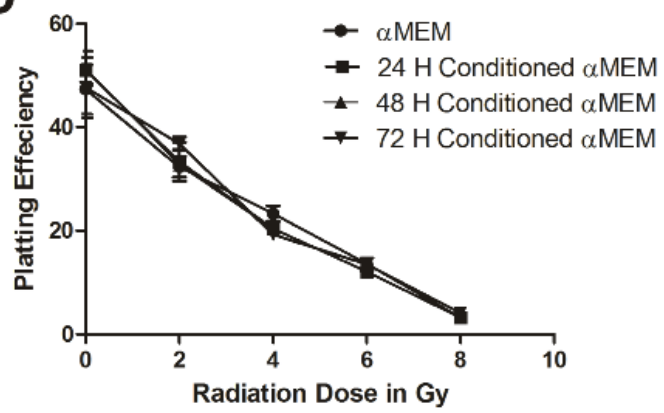

Figure.6.5.6: aMSCs do not potentiate Head and Neck cancer in-vitro

Exponentially growing Head and Neck cancer FaDu cells were plated in 6 well plates at different densities and irradiated with 2, 4, 6, and $8 \mathrm{~Gy}$. After irradiation, media was replaced with $\alpha$-MEM or DMEM conditioned media for aMSCs that have been in culture for 24,48 , and 72 hours. 10 days later, colonies were counted. (A) Represents the relative survival fraction Log of FaDu cells with aMSCS DMEM conditioned media. (B) Represents the platting efficiency of FaDu cells with aMSCs DMEM conditioned media. (C) Represents the relative survival fraction Log of FaDu cells 
with aMSCs $\alpha$-MEM conditioned media. (D) Represents the platting efficiency of FaDu cells with aMSCs $\alpha$-MEM conditioned media. Data presented as the mean \pm the standard error of the mean (SEM).

\subsection{DISCUSSION}

We were able to generate, expand and validate plastic-adherent aMSCs which have consistent high expression of MSCs-expected surface antigens and multi-lineage differentiation potential. In a previous study [159], we proved that aMSCs are relatively radio-resistant and can be applied as a cell therapy model in RT normal tissue injury management, including our current RIOM before and during the radiotherapy. In addition, we have generated a $100 \%$ survival single dose RIOM mouse. An earlier study by Schmidt, M et al., showed that there was a significant improvement of the $\mathrm{ED}_{50}$ of RIOM in fractionated RT with intravenous transplantation of $\mathrm{BM}$ and bmMSCs, (ED $D_{50}$ is the RT dose needed to cause epithelial ulceration in $50 \%$ of animals) [48]. There was a marked difference in the RIOM ulcer duration between their model and ours. Our model of single dose RIOM showed an ulcer duration mean of $5.6 \pm 0.3$ days $(M \pm S E M)$, while their model had an ulcer duration of $2.9 \pm 0.7$ days $(M \pm S D)$. In addition, there was a difference in the mean time-to-appear (latency) of the epithelial ulceration in their fractionated RT model (9.4-10.2 days and 2.6-3.6) and our single dose RT model ( 9 days and 5.6 days). Such differences are due to the difference in dose delivery, energy applied (theirs was $200 \mathrm{kVp}$ and ours was $120 \mathrm{kVp}$ ), and setup. Although they produced a different fractionated RT RIOM mouse model, they reached the same conclusion as we did in our study, that the effect of MSCs therapy is 
dependent on the time of the therapy relative to the RT exposure. They applied this conclusion on bmMSCs single dose protocol therapy in their model. However, when we started the therapy with syngenic aMSC before RT exposure, the cells significantly produced the highest clinically relevant therapeutic benefits in single (10 million cells dose) and multiple dosing protocols (2.5, 5, and 10 million cells / dose). Such therapeutic benefits were augmented by increasing the dose frequency. Schmidt et al. did not test these four therapeutic effects: the therapeutic effects of MSCs multiple doses therapy, the dose sequencing protocols (since they used a single dose protocol), the dose size change, or dose optimization. Their focus was on the improved ED50 (increased RT dose tolerance). But, in our study, the clinically relevant outcome was our main focus in terms of the significantly improved RIOM ulcer duration with up to $72 \%$ reduction in the RIOM injury duration (ulcer duration) due to the marked delay in ulcer time-to-appear and acceleration of ulcer time-to-heal with 5 doses of syngenic aMSCs of 2.5 million cells / dose. Schmidt et al's study concluded that the therapeutic benefits were dependent on MSCs type and dose size. We were able to show not only that syngenic aMSCs of an optimized dose size of only 2.5 million cells resulted in $72 \%$ reduction in the injury duration, but also we showed that, freshly cultured aMSCs produced more favorable therapeutic benefits in terms of improved animal hydration status that was evident by the significantly larger surface area of epithelialized tongue upper surface. We have to draw the attention to the combined optimization of the dose size and frequency, number of doses, and therapy onset time relative to RT exposure, which, from our experience, led to significant improvement in RIOM. The use of freshly cultured cells showed significantly better therapeutic effect. 
A second study on single dose RIOM therapy by Schmidt et al. showed improved ED 50 with mobilization of endogenous BM stem cells by using G-CSF stimulation compared to no improvement with using BM transplantation (68). They reported that the maximum number of circulating stem cells was reached at day (10) from the first stimulation. Their single dose RIOM has the same mean ulcer latency like ours, which was 9 days after RT exposure, although they used a different setup that granted fixed irradiated zone $\left(3 \times 3 \mathrm{~mm}^{2}\right)$ of the ventral aspect of the tongue. In addition, they used lower energy (25 $\mathrm{kVp}$ compared to ours $120 \mathrm{kVp}$ ) with a dose rate of $4.43 \mathrm{~Gy} / \mathrm{min}$ at a focus-to-surface of $15 \mathrm{~cm}$. These differences in dose delivery and setup resulted in the difference in the RIOM mean ulcer duration recorded in the two studies. Our ulcer duration mean was $5.6 \pm 0.3$ days $(M \pm S E M)$, while their ulcer duration mean was $2.0 \pm 0.4$ days $(M \pm S D)$. This clearly highlights the main purpose of our study. We were aiming towards the generation of a single dose RIOM with the longest possible inflammatory and ulcerative phase. To our knowledge, our RIOM ulcer duration is the longest ever-recorded ulcer duration in a single dose RIOM mouse model. Nevertheless, the two studies showed $100 \%$ survival in all experimental groups.

In our present study, we were able to reproduce our results with the 5 dose protocol of 2.5 million cells of syngenic freshly cultured aMSCs with another experiment with similar significant results (Figure.6.8.2.1.Supp).

The mechanisms of action hypothesized for MSCs anti-inflammatory properties have been investigated in many studies [55-60]. aMSCs showed enhanced anti-inflammatory IL-10 secretion [73] together with decreased pro-inflammatory TNF- $\alpha$, INF- $\gamma$, IL-1 $\beta$ and their downstream effects on various elements of the immune system. aMSCs, whether 
those who home to the radiation injury site or those who remain at the primary implantation site, can produce such paracrine effects [77]. In our present study, we noted that aMSCs were still detectable up to 14 days after injection at the site of implantation (Figure.6.5.3.F). Others hypothesized that, the local ulceration of oral epithelium thought to be caused by elimination of the local tissue stem cells. This leads to lost ability to completely restore mucosal repopulation after irradiation [48]. There might be a suggested combination of both theories. More studies are needed in this aspect to try to elaborate the mechanisms of such therapeutic effects of aMSCs.

The significant $72 \%$ reduction of the RIOM ulcer duration by our syngenic aMSCs model and optimized therapy protocol will have a significant improvement on the patients' quality of life, cancer radiotherapy delivery, and the economic cost. The few clinical data available for the application of MSCs in radiation-induced normal tissue injury showed promising therapeutic effects in many tissues. In radiation-induced bone injury, MSCs therapy caused early hematopoietic recovery with improved osteonecrosis. In radiationinduced intestinal injury, MSCs therapy produced significant repopulation of intestinal epithelium with improved pain, diarrhea, and hemorrhage. In radiation-induced skin injury, MSCs therapy showed significant improvement and repopulation of skin [71]. Our study opens the door for aMSCs therapy in a $1^{\text {st }}$ phase clinical trial. We hope our results have given the solid preclinical basis for the initiation of such a clinical trial. 


\subsection{CONCLUSION}

This study showed that syngenic freshly cultured aMSCs therapy resulted in a significant $72 \%$ reduction in radiation-induced oral mucositis duration by increasing the clinically relevant ulceration latency and accelerating its healing. aMSCs dose size and frequency, number of doses and onset of treatment are the main parameters that were optimized to yield the most favorable therapeutic benefit. Our study encourages the use of syngenic and freshly cultured cellular therapies. Our study results will allow widening of the tight therapeutic ratio of radiotherapy of Head and Neck cancer with decreasing the likelihood of alteration in radiation dose fractionation and their deteriorating side effects. Our findings indicate that we can minimize and accelerate the healing of radiation-induced oral mucositis, increase the rate of organ preservation, and minimize the radiation-induced normal tissue injury by using MSCs from adipose origin, for the first time. Our results indicate that aMSCs therapy lowered the radiation-induced oral mucositis side effects, mainly the weight loss and the dehydration with a promise for a significant improvement of the quality of life. Our results showed that the protective and curative effect of aMSCs would minimize cancer therapy interruption which will allow better local tumor control.

\section{AKNOWLEDGEMENTS}

Osama Muhammad Maria is an awardee of the LDI/TD studentship. This study was supported partially by Ride To Conquer Cancer (RTCC, Jewish General Hospital Foundation) and Fonds de Recherche du Quebec - Santé (FRQS) grants. 


\section{DISCLOSURE OF POTENTIAL CONFLICT OF INTEREST}

None. 


\subsection{SUPPLEMENTAL DATA}

\subsubsection{Tables}

\begin{tabular}{|l|l|l|l|}
\hline & Time-To-Appear & Healed by day & Ulcer Duration \\
\hline IR & $9.3 \pm 0.3$ & $15 \pm 0.58$ & $5.6 \pm 0.3$ \\
\hline IR+aMSCs & $11.3 \pm 0.9$ & $13 \pm 0.58$ & $\mathbf{1 . 6} \pm \mathbf{0 . 3}$ \\
\hline IR+Fibroblasts & $9.3 \pm 0.3$ & $15 \pm 0.58$ & $5.6 \pm 0.3$ \\
\hline
\end{tabular}

Table.6.8.1.1: The mean \pm SEM of RIOM ulcer in days

\begin{tabular}{|l|l|l|l|}
\hline & Time-to-appear & Time-to-heal & Ulcer duration \\
\hline IR & $7.867-10.733$ & $12.517-17.483$ & $4.233-7.1$ \\
\hline IR+aMSCs & $7.541-15.126$ & $10.517-15.483$ & $0.233-3.1$ \\
\hline IR+Fibroblasts & $7.867-10.733$ & $12.517-17.483$ & $4.233-7.1$ \\
\hline
\end{tabular}

Table.6.8.1.2: 95\% confidence intervals of the clinical parameters of RIOM ulcer in days 


\subsubsection{Supplemental figures}
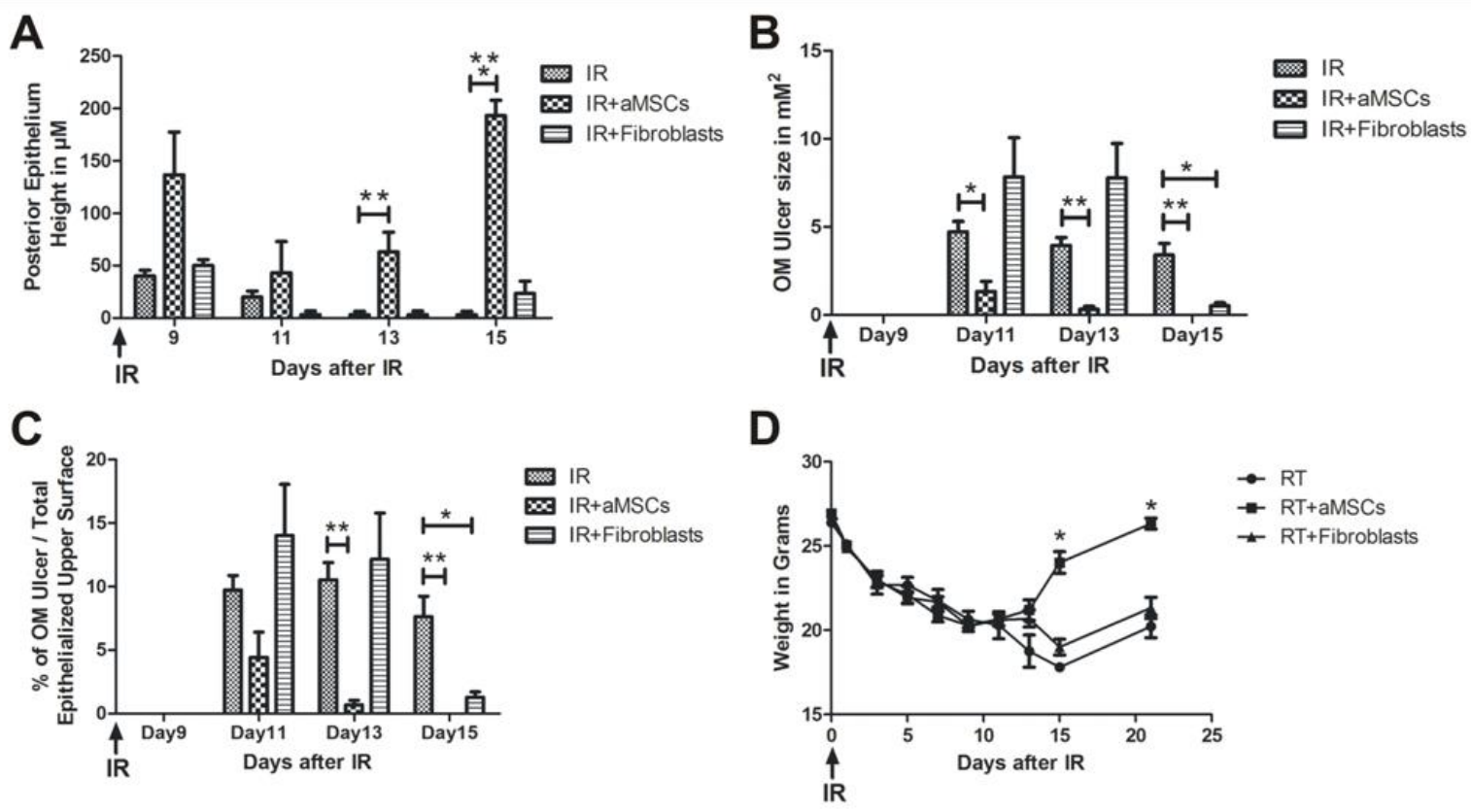

Figure.6.8.2.1.Supplemental: Syngenic freshly isolated aMSCs therapy therapeutic benefits were successfully reproducible

A second experiment was carried out with the same previous setup. In brief, 10 week-old male BALB/c mice were irradiated with 18 Gy at Day (0). Animals were divided into 3 groups (3 animals/group/time point): irradiated only (IR), irradiated and aMSCs-treated (IR+aMSCs), and irradiated and fibroblasts-treated (IR+Fibroblasts) groups. 2.5 million BALB/c freshly cultured aMSCs or fibroblasts were implanted intraperitoneally into the treatment groups at days $-1,1,3$, 5, and 7. (A) Represents the mean height of the posterior epithelium (eminence epithelium = ulcer floor) in $\mu \mathrm{M}$ of all experimental groups. (B) Represents the mean size of the RIOM ulcer in $\mu \mathrm{M}^{2}$ at different time points. (C) Represents the mean percentage of the ulcer size of the total 
epithelialized upper surface. (D) Represents the mean weight of animals at different time points. $(n=3),{ }^{*}=P$-value $<0.05,{ }^{* *}=P$-value $<0.005$, and ${ }^{* * *}=P$-value $<0.0005$, and data presented as the mean \pm the standard error of the mean (SEM). 
This page is intentionally left blank 


\section{Chapter 7 DISCUSSION}

RIOM is a RT-induced normal tissue injury of an average duration of $2-4$ weeks that occurs in $80 \%$ of irradiated Head and Neck cancer patients. However, its incidence increases up to $100 \%$ in altered fractionation Head and Neck cancer patients. It is a self-limited inflammatory injury if the patient survives, and sometimes, it is a lethal inflammation if the patient is elderly and sick with altered fractionation RT dose schedules [1]. Such inflammation is mediated and amplified by TNF- $\alpha, \mathrm{IL}-1 \beta$, ROS, and IL-6 [7, 126].

The poor prognosis, loss of local tumor control, cancer treatment interruption, tight therapeutic ratio, the negative dramatic effect on the patient's quality of life, the added economic cost, and the unsatisfactory RIOM available therapies, were the main reasons for our study. It has been proposed that RIOM is a five phase inflammatory reaction to radiation injury [126]. MSCs have been reported to have anti-inflammatory properties [56, 144-147]. These anti-inflammatory properties are mediated by their secretion of PGE-2, NO, TGF- $\beta$, IL-10, HGF and IDO. The result of their action is the enhanced secretion of the anti-inflammatory cytokine IL-10, and reduced bioavailability of TNF- $\alpha$, and IL-1 $\beta$ [191]. Therefore, we hypothesized that aMSCs can minimize and/or repair RIOM owing to their anti-inflammatory properties which oppose the RIOM pro-inflammatory process.

Reducing the duration and the severity of RIOM are the two main parameters needed to achieve significantly satisfactory and clinically relevant therapeutic benefit, allowing us to widen the tight therapeutic ratio, improve the local tumor 
control, and avoid cancer therapy interruption in order to increase cancer survival rates and improve organ preservation.

Another characteristic of MSCs that has been useful is their radiation resistance, which allows these cells to be a reliable candidate in RORM therapies, especially during and/or before RT $[93,95,104]$. Such studies have been conducted on bmMSCs only. Nevertheless, do MSCs from different tissues behave the same? We had to answer this question before testing our hypothesis with MSCs from adipose origin, since all previous radiation sensitivity studies have been carried out on bmMSCs [104, 106, 184]. We decided to use MSCs from adipose tissue due to their source abundance, prominent anti-inflammatory effects, enhanced IL-10 secretion, easy isolation, and high yield upon tissue culture expansion [156, 173]. The two main objectives of our first experiments were to isolate, expand, and characterize aMSCs, and to test their biological sensitivity/resistance to ionizing radiation exposure. For that first part of our study, we aimed to evaluate the biological response of aMSCs to radiation exposure in comparison to $4 \mathrm{~T} 1$ cells, a mesenchymal-like cancer cell model that has considerable ionizing radiationresistant Cancer Stem Cells (CSC) subpopulation [109, 182], and to mouse fibroblast (NIH3T3-wt), a normal cell model. Different mechanisms have been reported as main pathways of such radio-resistance, such as cell cycle (CC) arrest (G2/M arrest) and activation of double stranded DNA (dsDNA) damage repair machinery; namely the homologous recombination repair (HRR) and nonhomologous end-joining repair (NHEJR) [95-99]. These mechanisms were also demonstrated to be responsible for the RT resistance of cancer stem cells (CSC), 
also known as cancer initiating cells, which have been linked to cancer disease recurrence and aggression $[192,193]$. Thus, the aim was to explore these pathways in irradiated aMSCs compared to 4T1 and NIH3T3-wt cells.

We were able to reproducibly isolate, expand and characterize aMSCs with constant high expression of surface antigens expected on MSCs (Sca-1, CD106, CD105, CD73, CD29, and CD44), together with no expression of hematopoietic stem cells surface antigens (CD11b, and CD45) as expected. Our aMSCs were able to differentiate into functional adipocytes, chondrocytes, and osteocytes. aMSCs proliferation and multi-lineage differentiation potentials were not affected by exposure to RT up to 8 Gy as tested for 7 days in monolayer culture.

When we compared the biological response of aMSCs to those of 4T1 and NIH3T3wt, we found that the survival fraction and the platting efficiency of irradiated aMSCs were higher than those of $4 \mathrm{~T} 1$ and NIH3T3-wt. While investigating the underlying mechanisms for such radiation resistance of aMSCs, we found that irradiated aMSCs showed a significantly higher and faster phosphorylation of $\mathrm{H} 2 \mathrm{AX}$ with a maximum peak reached only within 2 hours after RT. The phosphorylated H2AX ( $\gamma^{-}$ $\mathrm{H} 2 \mathrm{AX}$ ) was still detectable at 24 hours post-RT, a trend that was documented in a previous study for MSCs radiobiological response [96]. This signifies that aMSCs possess a robust and time-efficient DNA damage response. Downstream $\mathrm{y}-\mathrm{H} 2 \mathrm{AX}$ are two major dsDNA repair pathways; the HR and the NHEJ repair pathways, together with phosphorylation of ATM, as the most proximal station in stimulation of cell cycle arrest (G2/M). When tested, we found up regulated expression of Rad-51 
and DNA-PK proteins, signifying the stimulation of HR and NHEJ dsDNA damage repair pathways at comparable levels to $4 \mathrm{~T} 1$ cells.

The more interesting finding was the up regulated G2/M arrest which was significantly longer in aMSCs than in 4T1 cells, owing to the higher p-ATM in aMSCs as well. The subsequent DNA gene expression array showed the faster upregulation of almost all major DNA damage response genes; including HR, NHEJ, ATM/ATR, NER, BER, and MMR together with cell cycle arrest and anti-apoptotic genes within 2 hours after RT. These findings signify the higher alertness and readiness of the DNA damage response machinery after RT exposure. These same mechanisms have been reported to be responsible for bmMSCs RT resistance [71, $95,104,106,184,190]$.

Our experimental results were successful in answering the question we posed earlier about the similarity in radiobiological response of MSCs from different tissue origins (namely, the bmMSCs and aMSCs). Our study was the first to document this mechanistic similarity between BM and adipose tissue MSCs in their radio-resistant response. In addition, aMSCs showed longer G2/M arrest, a trend, which could predict that HR is the major dsDNA repair pathway in aMSCs as it dominates only in G2 and S phases. In brief, we showed that aMSCs are a relatively radio-resistant cellular model phenotypically and functionally. These findings encourage researchers to open the door more for this cellular model in RORM therapies.

After documenting the RT resistance of our aMSCs cellular model, we started to generate our RIOM mouse model by optimizing the RT dose and setup, animal age 
and weight, and post-irradiation animal care. Although many studies have generated RIOM $[39,50,53,194]$ animal models, most of them were artificial models and the tight duration of $\mathrm{OM}$ resulted in limitation of the experimental procedures. The main objective of our experimentations this time was to generate a RIOM mouse model having the longest possible ulcer duration using the maximally tolerated RT dose, signifying the need to develop a self-resolving lesion. That way, we will improve the histological characterization of RIOM at that tissue-damaging radiation dose in order to move the research study to finer and more precise treatment evaluation parameters.

We found that the severity of RIOM is dose dependent in terms of ulcer duration, size, time-to-appear (latency), time-to-heal, epithelium height, RT-related weight loss and gain, and RT-related dehydration. To our knowledge, we are the first study to generate a self-resolved 18 Gy single dose RIOM mouse model using orthovoltage X-rays irradiator with $5.6 \pm 0.3$ days duration and $100 \%$ survival. That long ulcerative phase duration will allow researchers to introduce more variables in experiments for better investigation of the injury therapies. In addition, we have shown that, total epithelialized upper surface area of the tongue is related to the dehydration and the nutritional status of the animal. Interestingly, we have shown that good postirradiation animal care; namely, sufficient post-irradiation hydration, is a lifesaver and a significant survival improvement tool. We have shown that animal weight is an indicator for severity of RIOM, general mouse condition, state of mouse hydration and nutrition, and mouse ability and ease to eat and drink. 
The last part of our study was the evaluation of aMSCs therapy for our generated RIOM mouse model. To our knowledge, this is the first study to test aMSCs therapy for RIOM. Our main objective was to demonstrate if we can achieve a measurable, reproducible, and clinically relevant therapeutic benefit with aMSCs therapy or not. We were aiming to get reliable preclinical data in preparation for future phase-I clinical trials. Our previously stated clinically relevant and histological parameters were significant to quantify the therapeutic effect of aMSCs therapy. The most important clinically relevant therapeutic achievement was the significant and reproducible $72 \%$ reduction in RIOM physical ulcer duration (from $5.6 \pm 0.3$ to $1.6 \pm$ 0.3 days) with considerable $95 \%$ confidence interval. This fulfilled the first main objective of our study, which was to significantly reduce the RIOM duration. This is expected to generate similar ratios of improvement in RIOM signs and symptoms, secondary infection risk, cancer treatment continuity, economic cost, resource consumption, and quality of life. The delayed latency and early cure in the aMSCstreated animal group was marked. The therapeutic benefit was dependent on the aMSCs dose size and frequency, number of doses and therapy start time relative to RT exposure. Our findings are similar to previous studies that stated the same influencing factors [141]. In addition, lesser weight loss and earlier weight gain were significantly noted with aMSCs therapy. We recommend starting aMSCs therapy before RT, since that protocol gave the best-recorded therapeutic effect. We also recommend using freshly cultured aMSCs in therapy rather than injecting justthawed frozen cells. Since we used syngenic cells, we support the use of autologous cells when available, as first choice therapy [79]. aMSCs dose size appears to be 
critical, since when it was increased beyond 2.5 million cells, we did not note any significant improvement but instead observed the opposite effect (5 million vs. 2.5 million frozen cells). We thought that increasing the dose size would lead to greater suppression of the animal's immune system and consequently lower inflammatory reaction at the injury site, however that was not the case. Therefore, it is the optimal dose size, and not the maximal dose, that should be used to achieve the maximal therapeutic benefit. With these results, we have fulfilled our second main objective, which was to significantly reduce RIOM severity. This significant reproducible reduction in RIOM duration and severity may significantly improve a patient's quality of life and local cancer control, and save resources.

The final question we then aimed to answer was about the possibility of an aMSCsmediated tumor enhancement effect. Our in-vitro studies showed that aMSCs therapy does not lead to tumor cell enhancement. Nevertheless, this question needs to be addressed using an in-vivo model as well.

Regarding the mechanism of action of MSCs, as stated earlier, researchers are suggesting that, the therapeutic benefits of MSCs in RORM might be mediated by their paracrine effects with or without homing to the injury site, rather than their differentiation properties replacing the damaged cells $[55,70,71,195,196]$. However, more studies are needed to explore these mechanisms.

Regarding the challenges of MSCs therapies in general, MSCs spontaneous transformation in culture leading to tumorigenesis is a possible occurrence with invitro murine MSCs cultures, and less frequently with human MSCs [197-206]. Therefore, frequent characterization and monitoring the cells prior to in-vivo use is 
crucial for each dose. With murine MSCs, we recommend testing the cells in animals to rule out tumor formation before using them. It is also recommended to do karyotyping analysis of human MSCs prior to the therapy in order to clear out any suspect of chromosomal aberrations, mutations, or spontaneous transformation [207-212]. A standardized production and safety analysis of MSCs should be constructed and applied. Another challenge with MSCs might be the heterogeneous nature of an MSC population, which might affect their overall RT resistance since cells may not have equal resistance $[71,89]$. However, cell sorting may be possible using biomarkers identifying cells with higher RT resistance in a way to generate homogeneous population of aMSCs with similar RT resistance. Nevertheless, it is important to remember that radio-resistance would be detrimental if the MSCs are transformed, as that transformation will result in uncontrollable radio-resistant tumor [99]. 
This page is intentionally left blank 


\section{Chapter 8 FINAL CONCLUSIONS}

Irradiated and non-irradiated aMSCs were able to differentiate into adipocytes, chondrocytes and osteocytes with no significant difference. Irradiated aMSCs maintained the expression of mesenchymal stromal/stem cells (MSCs) surface antigens and, as expected, were negative for hematopoietic stem cells (HSCs) surface antigens when tested up to 7 days after irradiation with doses up to 8 Gy on the monolayer culture, with no significant difference.

Clonogenically, irradiated aMSCs had higher relative survival fraction (rSF) and plating efficiency (PE) than 4T1 and NIH3T3-wt cells. Irradiated aMSCs expressed higher $\gamma-\mathrm{H} 2 \mathrm{AX}$ and showed significantly faster and more time-efficient radiationinduced DNA damage response evident by up regulated DNA-PKcs and RAD51. Two hours after irradiation, most of the aMSCs DNA damage/repair-related genes showed up regulation that disappeared within 6 hours after IR. Irradiated aMSCs showed a significant rise and an earlier peak of p-ATM-dependent and -independent (p84/5E10-mediated) G2/M CC arrest compared to 4T1 and NIH3T3-wt cells. The latter is considered the main DNA repair activated mechanism to shift aMSCs DNA repair towards the HR pathway. That might conclude that HR is the main DNA repair pathway in aMSCs radio-biological response. After ionizing radiation exposure, aMSCs showed a robust and time-efficient radiation-induced DNA damage repair response, stable phenotypical characteristics and multi-lineage differentiation potential, recommending them as reliable candidates for cell therapy in radiation oncology regenerative medicine during or before radiotherapy. 
We generated a self-resolved single dose radiation-induced mouse model with 18 Gy orthovoltage X-rays irradiator. Our mouse model ulcer size, total upper epithelialized tongue surface, and epithelium height were radiation dose-dependent. With a single dose of 18 Gy, we achieved a self-resolved radiation-induced oral mucositis ulceration of $5.6 \pm 0.3$ days duration with $100 \%$ animal survival rate. Above the18 Gy dose, mice could not survive due to severe mucositis that resulted in uncorrectable weight loss and dehydration. We could use the animal weight loss as one important parameter for the severity and the phase of the $\mathrm{OM}$, and total tongue epithelialized upper surface as an indicator for mouse hydration status. Postirradiation hydration is a lifesaving procedure that significantly increased mouse survival up to $100 \%$.

The clinically relevant and histological parameters of radiation-induced oral mucositis ulcer include ulcer size and ulcer size \% (ulcer size/total epithelialized upper surface of the tongue), ulcer duration, ulcer time-to-appear (latency), ulcer time-to-heal, posterior upper surface epithelium height (intermolar eminence epithelium height).

One dose of intraperitoneally injected aMSCs only showed a late significant weight gain; however, when we increased the dose number and accelerated the dosing frequency, significantly less weight loss was evident as well. Moreover, 5 doses of intraperitoneally-injected 2.5 million freshly cultured syngenic aMSCs significantly showed the highest weight gain and least weight loss. This therapy-dosing schedule led to a significant $72 \%$ reduction in radiation-induced oral mucositis ulcer duration (from $5.6 \pm 0.3$ to $1.6 \pm 0.3$ days). In addition, an improved picture was documented 
at the clinically relevant and histological parameters of the radiation-induced oral mucositis ulcer, e.g. significantly smaller ulcer size and ulcer size percentage, longer time-to-appear (delayed latency), shorter time-to-heal (accelerated healing), lesser weight loss, higher weight gain, and longer posterior epithelium height.

Total tongue upper epithelialized surface could be used as an indicator for mouse hydration status, which was significantly improved in animals treated with 5 doses of 2.5 million freshly-cultured aMSCs, a regimen in which the first dose was given 1 day before radiation exposure, and the subsequent four doses every other day. This 2.5 million dose regimen was the best aMSCs dosing therapy regimen we used. We also noted that aMSCs therapy did not enhance the Head and Neck cancer cells invitro. 
This page is intentionally left blank 


\section{Chapter 9 SUMMARY}

For the first time in our radiation oncology translational research lab, we were able to generate, expand and validate plastic-adherent aMSCs, which have consistent high expression of MSCs-expected surface antigens and multi-lineage differentiation potential. Our aMSCs were shown to be radio-resistant cells that can be applied as a cell therapy model in radiation oncology regenerative medicine therapies including our current study (radiation-induced oral mucositis) before and/or during the radiotherapy. Their radiation resistance mechanisms include rapid dsDNA damage response activation through $\mathrm{HR}$. NHEJ, and G2/M arrest pathways. We generated our self-resolved single dose radiation-induced oral mucositis mouse model in preparation for testing the aMSCs therapy. We successfully proved our study concept that, after irradiation, aMSCs-treated animals significantly showed shorter ulcer duration (1.6 \pm 0.3 days instead of $5.6 \pm 0.3$ days), smaller ulcer size, and thicker upper posterior epithelium of the tongue at ulcer floor. In addition, aMSCs therapy led to longer time-to-appear and shorter time-to-heal of the radiationinduced oral mucositis ulcer. aMSCs therapy significantly minimized weight loss, improved weight gain, and lowered the injury-related dehydration in the treated animals. aMSCs significantly reduced the radiation-induced oral mucositis severity and duration which are the two major treatment course-influencing factors. Furthermore, aMSCs conditioned media did not increase Head and Neck cancer cells (FaDu tumor cells) clonogenicity in-vitro. $\alpha$-MEM and DMEM media can be safely used for expanding aMSCs without any detectable phenotype change. Moreover, we determined that aMSCs were could be tracked in vivo at the primary 
injection site for up to 14 days after administration. In aMSCs therapy, dose size and frequency, number of doses as well as therapy start time are the main parameters for improving therapy outcome. In addition, using freshly cultured cells enhances the therapeutic outcome of aMSCs therapy rather than using just-thawed frozen cells. Frequent monitoring and characterization of the aMSCs cells is a critical and mandatory step before their use in vivo in order to screen for phenotype changes or cellular transformation. Standardized production of MSCs should be controlled.

More studies are needed for confirming the radio-protective mechanism of action of aMSCs. That mechanism of action was suggested to be the enhanced antiinflammatory IL-10 secretion together with the reduction of the bioavailability of INF$\mathrm{Y}, \mathrm{IL}-1 \beta$, and TNF- $\alpha$ which are the main pro-inflammatory mediators for RIOM tissue injury. 
This page is intentionally left blank 


\section{Chapter $10 \quad$ STUDY IMPACT}

We were the first to address the ionizing radiation resistance of adipose tissuederived mesenchymal stromal cells describing and qualifying their radio-biological response, concluding that, MSCs from different tissue origins (BM and adipose tissue) behave similarly in their radio-biological response.

We were the first to generate a single dose radiation-induced oral mucositis mouse model with the longest possible ever-recorded oral mucositis inflammatory and ulcerative phase.

We were the first to use syngenic freshly cultured adipose tissue-derived mesenchymal stromal cells in the prevention and the treatment of radiation-induced oral mucositis achieving such impressive significant $72 \%$ reduction in the injury duration (RIOM ulcer duration).

We expect that, our study results will allow for widening of the tight therapeutic ratio of radiotherapy of Head and Neck cancer with decreasing the likelihood of alteration in radiation dose fractionation and their side effects.

Our results proved that, we could minimize and accelerate the healing of radiationinduced oral mucositis, increase the rate of organ preservation, and minimize and cure the radiation-induced normal tissue injury by syngenic aMSCs therapy. Our results showed that aMSCs therapy lowered the radiation-induced oral mucositis side effects, mainly the weight loss and the dehydration, with significant improvement of the quality of life.

Our results suggest better local tumor control, as they will improve the local radiotherapy delivery. 
This page is intentionally left blank 


\section{ABBREVIATIONS}

aMSCs adipose Mesenchymal Stromal/Stem Cells

ATM Ataxia Telangiectasia Mutant Kinase

BBB Blood brain barrier

BER Base Excision Repair

B-FGF Basic fibroblast growth factor

BM Bone marrow

bmMSCs Bone marrow-derived mesenchymal stromal/stem cells

BM Bone Marrow

CA Clonogenic Assay

CNS Central nervous system

CT Chemotherapy

CA Clonogenic Assay

Cc Cell Cycle

CSC Cancer Stem cells

DNA-PKcs DNA-dependent Protein Kinase Catalytic Subunit

DP Differentiation Percentage

DSBs Double Stranded DNA Breaks 


\begin{tabular}{ll} 
dsDNAR & Double Stranded DNA Repair \\
EGF & Epidermal growth factor \\
EPC & Endothelial progenitor cells \\
FABP-4 & Fatty Acid Binding Protein-4 \\
FGF-2 & Fibroblast Growth Factor-2 \\
FC & Flow Cytometry \\
G-CSF & Granulocyte-Colony Stimulating Factor \\
GFAP & Glial fibrillary acidic protein \\
hESC & Human embryonic stem cell \\
HGF & Hepatocyte growth factor \\
ILNSC & Human neural stem cell \\
IL-6 & Interleukin-6 \\
HSCs & Hematopoietic Stem Cells \\
HRP & Horseradish Peroxidase \\
\hline HRR & Homologous Recombination Repair \\
\hline Ins & Interferon-gamma \\
\hline Intin growth factor
\end{tabular}




$\begin{array}{ll}\text { IL-10 } & \text { Interleukin-10 } \\ \text { IHC } & \text { Immunohistochemistry } \\ \text { IL-6 } & \text { Interleukin-6 } \\ \text { IR } & \text { Ionizing radiation, Irradiation, Irradiated } \\ \text { IHC } & \text { Immunohistochemistry } \\ \text { MMR } & \text { Mismatch repair } \\ \text { MSCs } & \text { Mesenchymal Stromal/Stem cells } \\ \text { MAPK } & \text { Mitogen-activated protein kinase } \\ \text { MSCs } & \text { Mesenchymal Stromal/Stem cells } \\ \text { NF-KB } & \text { Nuclear factor kappa-B } \\ \text { NER } & \text { Nucleotide Excision Repair } \\ \text { PI } & \\ \text { NHEJR } & \text { Non-Homologous End-joining Repair } \\ \text { NIH3T3-wt } & \text { Normal Mouse Fibroblasts cell line } \\ \text { NF-K } & \text { Nuclear factor kappa-B } \\ \text { OMal mucositis } \\ \text { Propidium lodide }\end{array}$

P84/5E10 The Nuclear Protein Encoded by the N5 Gene 


\begin{tabular}{|c|c|}
\hline SEM & Standard Error of the Mean \\
\hline SVF & Stromal Vascular Fraction \\
\hline RIOM & Radiation-Induced Oral Mucositis \\
\hline RORM & Radiation Oncology Regenerative Medicine \\
\hline RT & Radiation \\
\hline RIOM & Radiation-Induced Oral Mucositis \\
\hline RORM & Radiation Oncology Regenerative Medicine \\
\hline RT & Radiation \\
\hline RT & Radiation, Radiotherapy \\
\hline RTOG & Radiation Therapy Oncology Group \\
\hline rSF & Relative Survival fraction \\
\hline RORM & Radiation Oncology Regenerative Medicine \\
\hline $\mathbf{R b}$ & Retinoblastoma \\
\hline SEM & Standard Error of the Mean \\
\hline SSBs & Single Stranded Breaks \\
\hline ssDNA & Single Stranded DNA \\
\hline SVF & Stromal Vascular Fraction \\
\hline TB & Toluidine Blue \\
\hline
\end{tabular}


TNF- $\alpha \quad$ Tumor necrosis factor-alpha

VEGF Vascular endothelial growth factor

WCCNR Western Consortium for Cancer Nursing Research

WHO World Health Organization

4T1 Mouse Breast Cancer Cell Line 
This page is intentionally left blank 


\title{
APPENDIX
}

\section{Adipose mesenchymal stromal cells response to ionizing radiation}

\author{
OSAMA MUHAMMAD MARIA ${ }^{1,2,3}$, SLAWOMIR KUMALA ${ }^{3,4,5}$, MITRA HERAVI $^{3,4,6}$, \\ ALASDAIR SYME ${ }^{3,5,7}$, NICOLETTA ELIOPOULOS $^{2,4} \&$ THIERRY MUANZA ${ }^{1,3,4,5}$
}

\author{
${ }^{1}$ Experimental Medicine Department, Fezvish General Hospital, Montreal, Canada, ${ }^{2}$ Surgery Department, Faculty of \\ Medicine, Fewish General Hospital, Montreal, Canada, ${ }^{3}$ Radiation Oncology Department, Fezuish General Hospital, \\ Montreal, Canada, ${ }^{4}$ Lady Davis Institute for Medical Research, Fewish General Hospital, Montreal, Canada, \\ ${ }^{5}$ Oncology Department, McGill University, Montreal, Canada, ${ }^{6}$ Human Genetics Department, McGill University, \\ Montreal, Ganada, and ${ }^{7}$ Medical Physics Unit, Fewish General Hospital, Montreal, Canada
}

\begin{abstract}
Background aims. This study evaluates the biological response of adipose tissue-derived mesenchymal stromal cells (aMSCs) to ionizing radiation (IR). Methods. Irradiated $\mathrm{BALB} / \mathrm{c}$ mice aMSCs were characterized for functionality and phenotype. The clonogenic capacity of irradiated aMSCs was assessed and compared with those of metastatic breast cancer cell line (4T1) and normal mouse fibroblasts (NIH3T3-wt). We investigated the IR-induced DNA damage response, apoptosis, changes in cell cycle (CC) dynamics and protein and gene expression. Results. Irradiated and non-irradiated aMSCs were able to differentiate into adipocytes, chondrocytes and osteocytes with no significant difference. Irradiated aMSCs maintained the expression of mesenchymal stromal cells (MSCs) surface antigens and, as expected, were negative for hematopoietic stem cells (HSCs) surface antigens when tested up to 7 days after IR for all irradiation doses with no significant difference. Clonogenically, irradiated aMSCs had higher relative survival fraction and plating efficiency than 4T1 and NIH3T3-wt. Irradiated aMSCs expressed higher $\square \mathrm{H} 2 \mathrm{AX}$ and significantly showed faster and more time-efficient IR-induced DNA damage response evident by up-regulated DNA-PKcs and RAD51. Two hours after IR, most of aMSCs DNA damage/repairrelated genes showed up-regulation that disappeared within $6 \mathrm{~h}$ after IR. Irradiated aMSCs showed a significant rise and an earlier peak of p-ATM-dependent and -independent (p84/5E10-mediated) G2/M CC arrest compared with 4T1 and NIH3T3-wt. Conclusions. After IR exposure, aMSCs showed a robust and time-efficient radiation-induced DNA damage repair response, stable phenotypical characteristics and multi-lineage differentiation potential, suggesting they may be reliable candidates for cell therapy in radiation oncology regenerative medicine.
\end{abstract}

Key Words: adipose, cell cycle, DNA damage repair, G2/M arrest, gene expression, ionizing radiation, mesenchymal stromal cells, radiation resistance

\section{Introduction}

Adipose tissue-derived mesenchymal stromal cells (aMSCs) are multi-potent progenitor cells located in the stromal vascular fraction (SVF) of adipose tissue [1]. They are characterized by expressing surface antigens Sca 1, CD106, CD 105, CD73, CD29 and CD44 and lack the expression of hematopoietic stem cell (HSC) surface antigens (e.g., CD11b and CD45) [1-3]. In addition to their multi-lineage differentiation potential, they have anti-inflammatory/immunemodulatory and paracrine effects. They also have the ability to home to the site of tissue injury after irradiation and inflammation $[1,4,5]$. aMSCs' osteogenic differentiation potential for instance has been applied in preclinical studies [6]. aMSCs are promising for cellular therapies because of their prominent antiinflammatory effects, enhancement of interleukin (IL)-10 secretion, ease of isolation, high cell count after expansion and their source abundance [7].

In radiation oncology regenerative medicine applications, aMSC therapy is a rapidly growing domain of cell therapy for radiation-induced normal tissue injury. aMSCs have been investigated in many studies for cutaneous radiation syndrome [8-12] and photoaging [13] where they have shown significant tissue repair. In addition, aMSCs systemic cell therapy has shown significant restoration and improvement of acute salivary gland [14] and intestine injuries [15-18] induced by ionizing radiation (IR). Furthermore,

Correspondence: Thierry Muanza, MD, MSc, FRCPC, Radiation Oncology Translational Research Lab, Department of Radiation Oncology, Jewish General Hospital and Lady Davis Institute Research Centre, McGill University, 3755 Côte-St.-Catherine Road, Suite G002, Montréal, Québec, Canada, H3T 1 E2. E-mail: tmuanza@yahoo.com 
This page is intentionally left blank 


\section{REFERENCES}

1. Muanza, T.M., et al., Evaluation of radiation-induced oral mucositis by optical coherence tomography. Clin Cancer Res, 2005. 11(14): p. 5121-7.

2. Nakajima, N., et al., Evaluation of edaravone against radiation-induced oral mucositis in mice. J Pharmacol Sci, 2015. 127(3): p. 339-43.

3. Scully, C., J. Epstein, and S. Sonis, Oral mucositis: a challenging complication of radiotherapy, chemotherapy, and radiochemotherapy. Part 2: diagnosis and management of mucositis. Head Neck, 2004. 26(1): p. 77-84.

4. Kostler, W.J., et al., Oral mucositis complicating chemotherapy and/or radiotherapy: options for prevention and treatment. CA Cancer J Clin, 2001. 51(5): p. 290-315.

5. Cuba Lde, F., et al., Antioxidant Agents: A Future Alternative Approach in the Prevention and Treatment of Radiation-induced Oral Mucositis? Altern Ther Health Med, 2015. 21(2): p. 36-41.

6. Naidu, M.U., et al., Chemotherapy-induced and/or radiation therapy-induced oral mucositis--complicating the treatment of cancer. Neoplasia, 2004. 6(5): p. 423-31.

7. Scully, C., J. Epstein, and S. Sonis, Oral mucositis: a challenging complication of radiotherapy, chemotherapy, and radiochemotherapy: part 1, pathogenesis and prophylaxis of mucositis. Head Neck, 2003. 25(12): p. 1057-70.

8. Riesenbeck, D. and W. Dorr, Documentation of radiation-induced oral mucositis. Scoring systems. Strahlenther Onkol, 1998. 174 Suppl 3: p. 44-6. 
9. Judith E. Raber-Durlacher, S.E., and Andrei Barasch, Oral mucositis. Oral Oncology, 2010. 46 p. 452-456.

10. Van den Wyngaert, T., Topical honey application to reduce radiation-induced oral mucositis: a therapy too sweet to ignore? J Evid Based Dent Pract, 2012. 12(4): p. 203-5.

11. Song, J.J., P. Twumasi-Ankrah, and R. Salcido, Systematic review and metaanalysis on the use of honey to protect from the effects of radiation-induced oral mucositis. Adv Skin Wound Care, 2012. 25(1): p. 23-8.

12. Khanal, B., M. Baliga, and N. Uppal, Effect of topical honey on limitation of radiation-induced oral mucositis: an intervention study. Int J Oral Maxillofac Surg, 2010. 39(12): p. 1181-5.

13. Hawley, P., et al., A randomized placebo-controlled trial of manuka honey for radiation-induced oral mucositis. Support Care Cancer, 2014. 22(3): p. 75161.

14. Sheibani, K.M., et al., Efficacy of benzydamine oral rinse in prevention and management of radiation-induced oral mucositis: A double-blind placebocontrolled randomized clinical trial. Asia Pac J Clin Oncol, 2015. 11(1): p. 227.

15. Gruber, S., et al., Modulation of radiation-induced oral mucositis by pentoxifylline: Preclinical studies. Strahlenther Onkol, 2015. 191(3): p. 242247. 
16. Gautam, A.P., et al., Low level laser therapy against radiation induced oral mucositis in elderly head and neck cancer patients-a randomized placebo controlled trial. J Photochem Photobiol B, 2015. 144: p. 51-6.

17. De Ryck, T., et al., 8-prenylnaringenin and tamoxifen inhibit the shedding of irradiated epithelial cells and increase the latency period of radiation-induced oral mucositis : cell culture and murine model. Strahlenther Onkol, 2015. 191(5): p. 429-36.

18. Bonfili, P., et al., Oral Platelet Gel Supernatant Plus Supportive Medical Treatment Versus Supportive Medical Treatment in the Management of Radiation-induced Oral Mucositis: A Matched Explorative Active Control Trial by Propensity Analysis. Am J Clin Oncol, 2015.

19. Xu, X.L., et al., [Effect of "Xinjingjie mouthrinse" on prevention and treatment of radiation-induced oral mucositis]. Shanghai Kou Qiang Yi Xue, 2014. 23(6): p. 727-30.

20. Xie, N., et al., [Analgesic effect of DICLORAL on radiation-induced oral mucositis]. Shanghai Kou Qiang Yi Xue, 2014. 23(3): p. 356-8.

21. Watanabe, S., et al., Assessment of the hamster cheek pouch as a model for radiation-induced oral mucositis, and evaluation of the protective effects of keratinocyte growth factor using this model. Int J Radiat Biol, 2014. 90(10): p. 884-91.

22. Sahebjamee, M., et al., Comparative Efficacy of Aloe vera and Benzydamine Mouthwashes on Radiation-induced Oral Mucositis: A Triple-blind, Randomised, Controlled Clinical Trial. Oral Health Prev Dent, 2014. 
23. Rizk, N.N., V.A. Georgescu, and G. Jain, Use of topical lidocaine, diphenhydramine hydrochloride, nystatin, and gabapentin swish in treatment for post-radiation neuropathy and oral mucositis. Pain Physician, 2014. 17(3): p. E416-8.

24. Li, C.J., et al., Assessment of the effect of local application of amifostine on acute radiation-induced oral mucositis in guinea pigs. J Radiat Res, 2014. 55(5): p. 847-54.

25. Hadjieva, T., et al., Treatment of oral mucositis pain following radiation therapy for head-and-neck cancer using a bioadhesive barrier-forming lipid solution. Support Care Cancer, 2014. 22(6): p. 1557-62.

26. Ghalayani, P., et al., Comparison of triamcinolone acetonide mucoadhesive film with licorice mucoadhesive film on radiotherapy-induced oral mucositis: $A$ randomized double-blinded clinical trial. Asia Pac J Clin Oncol, 2014.

27. Elkerm, Y. and R. Tawashi, Date palm pollen as a preventative intervention in radiation- and chemotherapy-induced oral mucositis: a pilot study. Integr Cancer Ther, 2014. 13(6): p. 468-72.

28. De Ryck, T., et al., 8-prenylnaringenin and tamoxifen inhibit the shedding of irradiated epithelial cells and increase the latency period of radiation-induced oral mucositis : Cell culture and murine model. Strahlenther Onkol, 2014.

29. Bossi, P., et al., Prevention and treatment of oral mucositis in patients with head and neck cancer treated with (chemo) radiation: report of an Italian survey. Support Care Cancer, 2014. 22(7): p. 1889-96. 
30. Sangthawan, D., T. Phungrassami, and W. Sinkitjarurnchai, $A$ randomized double-blind, placebo-controlled trial of zinc sulfate supplementation for alleviation of radiation-induced oral mucositis and pharyngitis in head and neck cancer patients. J Med Assoc Thai, 2013. 96(1): p. 69-76.

31. Rao, S., et al., The Indian Spice Turmeric Delays and Mitigates RadiationInduced Oral Mucositis in Patients Undergoing Treatment for Head and Neck Cancer: An Investigational Study. Integr Cancer Ther, 2013.

32. Lambrecht, M., et al., The effect of a supersaturated calcium phosphate mouth rinse on the development of oral mucositis in head and neck cancer patients treated with (chemo)radiation: a single-center, randomized, prospective study of a calcium phosphate mouth rinse + standard of care versus standard of care. Support Care Cancer, 2013. 21(10): p. 2663-70.

33. Steinmann, D., et al., Effect of Traumeel S on pain and discomfort in radiation-induced oral mucositis: a preliminary observational study. Altern Ther Health Med, 2012. 18(4): p. 12-8.

34. Cotrim, A.P., et al., Pharmacological protection from radiation +/- cisplatininduced oral mucositis. Int J Radiat Oncol Biol Phys, 2012. 83(4): p. 1284-90.

35. Ling, I.S. and B. Larsson, Individualized pharmacological treatment of oral mucositis pain in patients with head and neck cancer receiving radiotherapy. Support Care Cancer, 2011. 19(9): p. 1343-50.

36. Vayne-Bossert, P., et al., Effect of topical morphine (mouthwash) on oral pain due to chemotherapy-and/or radiotherapy-induced mucositis: a randomized double-blinded study. J Palliat Med, 2010. 13(2): p. 125-8. 
37. Ryu, S.H., et al., Therapeutic effects of recombinant human epidermal growth factor (rhEGF) in a murine model of concurrent chemo- and radiotherapyinduced oral mucositis. J Radiat Res, 2010. 51(5): p. 595-601.

38. Colella, G., et al., Efficacy of a spray compound containing a pool of collagen precursor synthetic aminoacids (I-proline, I-leucine, I-lysine and glycine) combined with sodium hyaluronate to manage chemo/radiotherapy-induced oral mucositis: preliminary data of an open trial. Int J Immunopathol Pharmacol, 2010. 23(1): p. 143-51.

39. Zhao, J., et al., R-Spondin 1 protects mice from chemotherapy or radiationinduced oral mucositis through the canonical Wnt/beta-catenin pathway. Proc Natl Acad Sci U S A, 2009. 106(7): p. 2331-6.

40. Simoes, A., et al., Laser phototherapy as topical prophylaxis against head and neck cancer radiotherapy-induced oral mucositis: comparison between low and high/low power lasers. Lasers Surg Med, 2009. 41(4): p. 264-70.

41. Manas, A., et al., Incidence of oral mucositis, its treatment and pain management in patients receiving cancer treatment at Radiation Oncology Departments in Spanish hospitals (MUCODOL Study). Clin Transl Oncol, 2009. 11(10): p. 669-76.

42. Murphy, C.K., et al., Efficacy of superoxide dismutase mimetic M40403 in attenuating radiation-induced oral mucositis in hamsters. Clin Cancer Res, 2008. 14(13): p. $4292-7$. 
43. Chen, J., [Effect of quadruple fluid aerosol inhalation on oral mucositis induced by radiotherapy in nasopharyngeal carcinoma and its mechanism]. Zhong Nan Da Xue Xue Bao Yi Xue Ban, 2007. 32(3): p. 527-30.

44. Ucuncu, H., et al., Vitamin E and L-carnitine, separately or in combination, in the prevention of radiation-induced oral mucositis and myelosuppression: a controlled study in a rat model. J Radiat Res, 2006. 47(1): p. 91-102.

45. Clarkson, J., Palifermin improves oral mucositis after high dose chemotherapy and radiotherapy plus stem cell transplantation in people with haematological cancers. Cancer Treat Rev, 2005. 31(5): p. 413-6.

46. Shih, A., et al., A research review of the current treatments for radiationinduced oral mucositis in patients with head and neck cancer. Oncol Nurs Forum, 2002. 29(7): p. 1063-80.

47. Epstein, J.B., et al., Benzydamine $\mathrm{HCl}$ for prophylaxis of radiation-induced oral mucositis: results from a multicenter, randomized, double-blind, placebocontrolled clinical trial. Cancer, 2001. 92(4): p. 875-85.

48. Schmidt, M., et al., Effects of bone marrow or mesenchymal stem cell transplantation on oral mucositis (mouse) induced by fractionated irradiation. Strahlenther Onkol, 2014. 190(4): p. 399-404.

49. Haagen, J., et al., Effect of selective inhibitors of inflammation on oral mucositis: preclinical studies. Radiother Oncol, 2009. 92(3): p. 472-6.

50. Dorr, W., K. Spekl, and M. Martin, Radiation-induced oral mucositis in mice: strain differences. Cell Prolif, 2002. 35 Suppl 1: p. 60-7. 
51. Guo, H., et al., Prevention of radiation-induced oral cavity mucositis by plasmid/liposome delivery of the human manganese superoxide dismutase (SOD2) transgene. Radiat Res, 2003. 159(3): p. 361-70.

52. Albert, M., et al., Modulation of radiation-induced oral mucositis (mouse) by selective inhibition of beta1 integrin. Radiother Oncol, 2012. 104(2): p. 230-4.

53. Burdelya, L.G., et al., Toll-like receptor 5 agonist protects mice from dermatitis and oral mucositis caused by local radiation: implications for headand-neck cancer radiotherapy. Int J Radiat Oncol Biol Phys, 2012. 83(1): p. 228-34.

54. Boquest, A.C., et al., Isolation of stromal stem cells from human adipose tissue. Methods Mol Biol, 2006. 325: p. 35-46.

55. Anderson, P., et al., Adipose-derived mesenchymal stromal cells induce immunomodulatory macrophages which protect from experimental colitis and sepsis. Gut, 2013. 62(8): p. 1131-41.

56. Doorn, J., et al., Therapeutic applications of mesenchymal stromal cells: paracrine effects and potential improvements. Tissue Eng Part B Rev, 2012. 18(2): p. 101-15.

57. De Miguel, M.P., et al., Immunosuppressive properties of mesenchymal stem cells: advances and applications. Curr Mol Med, 2012. 12(5): p. 574-91.

58. Ripoll, C.B., et al., Mesenchymal lineage stem cells have pronounced antiinflammatory effects in the twitcher mouse model of Krabbe's disease. Stem Cells, 2011. 29(1): p. 67-77. 
59. Ostanin, A.A., et al., Multiplex analysis of cytokines, chemokines, growth factors, MMP-9 and TIMP-1 produced by human bone marrow, adipose tissue, and placental mesenchymal stromal cells. Bull Exp Biol Med, 2011. 151(1): p. 133-41.

60. Patel, S.A., et al., Immunological properties of mesenchymal stem cells and clinical implications. Arch Immunol Ther Exp (Warsz), 2008. 56(1): p. 1-8.

61. Reinders, M.E., W.E. Fibbe, and T.J. Rabelink, Multipotent mesenchymal stromal cell therapy in renal disease and kidney transplantation. Nephrol Dial Transplant, 2010. 25(1): p. 17-24.

62. Marconi, S., et al., Human adipose-derived mesenchymal stem cells systemically injected promote peripheral nerve regeneration in the mouse model of sciatic crush. Tissue Eng Part A, 2012. 18(11-12): p. 1264-72.

63. Bouffi, C., et al., Multipotent mesenchymal stromal cells and rheumatoid arthritis: risk or benefit? Rheumatology (Oxford), 2009. 48(10): p. 1185-9.

64. Wang, Y., et al., [Inhibitory effect of resveratrol on expression of IL-1beta in mesenchymal stem cells exposed to radiation]. Zhonghua Lao Dong Wei Sheng Zhi Ye Bing Za Zhi, 2014. 32(2): p. 108-11.

65. Wang, H., et al., Hepatocyte growth factor gene-modified mesenchymal stem cells reduce radiation-induced lung injury. Hum Gene Ther, 2013. 24(3): p. $343-53$.

66. Lange, C., et al., Radiation rescue: mesenchymal stromal cells protect from lethal irradiation. PLoS One, 2011. 6(1): p. e14486. 
67. Klein, D., et al., Therapy with multipotent mesenchymal stromal cells protects lungs from radiation-induced injury and reduces the risk of lung metastasis. Antioxid Redox Signal, 2015.

68. Jiang, X., et al., Intravenous delivery of adipose-derived mesenchymal stromal cells attenuates acute radiation-induced lung injury in rats. Cytotherapy, 2015. 17(5): p. 560-70.

69. Horton, J.A., et al., Mesenchymal stem cells inhibit cutaneous radiationinduced fibrosis by suppressing chronic inflammation. Stem Cells, 2013. 31(10): p. 2231-41.

70. Chang, P., et al., Multi-therapeutic effects of human adipose-derived mesenchymal stem cells on radiation-induced intestinal injury. Cell Death Dis, 2013. 4: p. e685.

71. Nicolay, N.H., et al., Mesenchymal stem cells - A new hope for radiotherapyinduced tissue damage? Cancer Lett, 2015. 366(2): p. 133-40.

72. Schmidt, M., et al., Modification of radiation-induced oral mucositis (mouse) by adult stem cell therapy: single-dose irradiation. Radiat Environ Biophys, 2014. 53(4): p. 629-34.

73. Brooke, G., et al., Therapeutic applications of mesenchymal stromal cells. Semin Cell Dev Biol, 2007. 18(6): p. 846-58.

74. Chamberlain, G., et al., Concise review: mesenchymal stem cells: their phenotype, differentiation capacity, immunological features, and potential for homing. Stem Cells, 2007. 25(11): p. 2739-49. 
75. Bianco, P., et al., Bone marrow stromal stem cells: nature, biology, and potential applications. Stem Cells, 2001. 19(3): p. 180-92.

76. Baer, P.C. and H. Geiger, Adipose-derived mesenchymal stromal/stem cells: tissue localization, characterization, and heterogeneity. Stem Cells Int, 2012. 2012: p. 812693.

77. Francois, S., et al., Local irradiation not only induces homing of human mesenchymal stem cells at exposed sites but promotes their widespread engraftment to multiple organs: a study of their quantitative distribution after irradiation damage. Stem Cells, 2006. 24(4): p. 1020-9.

78. Chapel, A., et al., Mesenchymal stem cells home to injured tissues when coinfused with hematopoietic cells to treat a radiation-induced multi-organ failure syndrome. J Gene Med, 2003. 5(12): p. 1028-38.

79. Forcheron, F., et al., Autologous adipocyte derived stem cells favour healing in a minipig model of cutaneous radiation syndrome. PLoS One, 2012. 7(2): p. e31694.

80. Akita, S., et al., Noncultured autologous adipose-derived stem cells therapy for chronic radiation injury. Stem Cells Int, 2010. 2010: p. 532704.

81. Bargues, L., et al., [Present and future of cell therapy in burns]. Pathol Biol (Paris), 2011. 59(3): p. e49-56.

82. Francois, S., et al., Human mesenchymal stem cells favour healing of the cutaneous radiation syndrome in a xenogenic transplant model. Ann Hematol, 2007. 86(1): p. 1-8. 
83. Riccobono, D., et al., Application of adipocyte-derived stem cells in treatment of cutaneous radiation syndrome. Health Phys, 2012. 103(2): p. 120-6.

84. Kim, W.S., B.S. Park, and J.H. Sung, Protective role of adipose-derived stem cells and their soluble factors in photoaging. Arch Dermatol Res, 2009. 301(5): p. 329-36.

85. Lim, J.Y., et al., Systemic transplantation of human adipose tissue-derived mesenchymal stem cells for the regeneration of irradiation-induced salivary gland damage. PLoS One, 2013. 8(8): p. e71167.

86. Semont, A., et al., Mesenchymal stem cells improve small intestinal integrity through regulation of endogenous epithelial cell homeostasis. Cell Death Differ, 2010. 17(6): p. 952-61.

87. Semont, A., et al., Mesenchymal stem cells increase self-renewal of small intestinal epithelium and accelerate structural recovery after radiation injury. Adv Exp Med Biol, 2006. 585: p. 19-30.

88. Linard, C., et al., Repeated autologous bone marrow-derived mesenchymal stem cell injections improve radiation-induced proctitis in pigs. Stem Cells Transl Med, 2013. 2(11): p. 916-27.

89. Benderitter, M., et al., Stem cell therapies for the treatment of radiationinduced normal tissue side effects. Antioxid Redox Signal, 2014. 21(2): p. $338-55$.

90. Worku, M., et al., Sequential transformation of mesenchymal stem cells is associated with increased radiosensitivity and reduced DNA repair capacity. Radiat Res, 2013. 179(6): p. 698-706. 
91. Oliver, L., et al., Differentiation-related response to DNA breaks in human mesenchymal stem cells. Stem Cells, 2013. 31(4): p. 800-7.

92. Woodward, W.A., et al., WNT/beta-catenin mediates radiation resistance of mouse mammary progenitor cells. Proc Natl Acad Sci U S A, 2007. 104(2): p. $618-23$.

93. $\mathrm{Ni}$, J., et al., CD44 variant 6 is associated with prostate cancer metastasis and chemo-/radioresistance. Prostate, 2014. 74(6): p. 602-17.

94. Ziebarth, A.J., et al., Endoglin (CD105) contributes to platinum resistance and is a target for tumor-specific therapy in epithelial ovarian cancer. Clin Cancer Res, 2013. 19(1): p. 170-82.

95. Chen, M.F., et al., The sensitivity of human mesenchymal stem cells to ionizing radiation. Int J Radiat Oncol Biol Phys, 2006. 66(1): p. 244-53.

96. Prendergast, A.M., et al., Activation of DNA damage response pathways in human mesenchymal stem cells exposed to cisplatin or gamma-irradiation. Cell Cycle, 2011. 10(21): p. 3768-77.

97. Alexandrov, B.S., et al., Specificity and heterogeneity of terahertz radiation effect on gene expression in mouse mesenchymal stem cells. Sci Rep, 2013. 3: p. 1184.

98. Nicolay, N.H., et al., Mesenchymal stem cells retain their defining stem cell characteristics after exposure to ionizing radiation. Int J Radiat Oncol Biol Phys, 2013. 87(5): p. 1171-8.

99. Frosina, G., The bright and the dark sides of DNA repair in stem cells. J Biomed Biotechnol, 2010. 2010: p. 845396. 
100. Rich, J.N. and C.E. Eyler, Cancer stem cells in brain tumor biology. Cold Spring Harb Symp Quant Biol, 2008. 73: p. 411-20.

101. Rycaj, K. and D.G. Tang, Cancer stem cells and radioresistance. Int J Radiat Biol, 2014. 90(8): p. 615-21.

102. Tomao, F., et al., Emerging role of cancer stem cells in the biology and treatment of ovarian cancer: basic knowledge and therapeutic possibilities for an innovative approach. J Exp Clin Cancer Res, 2013. 32: p. 48.

103. Woodward, W.A. and R.G. Bristow, Radiosensitivity of cancer-initiating cells and normal stem cells (or what the Heisenberg uncertainly principle has to do with biology). Semin Radiat Oncol, 2009. 19(2): p. 87-95.

104. Nicolay, N.H., et al., Radio-resistant mesenchymal stem cells: mechanisms of resistance and potential implications for the clinic. Oncotarget, 2015. 6(23): p. 19366-80.

105. Wu, B., et al., [Expression of radioresistant genes survivin and HO-1 in mesenchymal stem cells]. Zhongguo Shi Yan Xue Ye Xue Za Zhi, 2011. 19(3): p. 805-8.

106. Sugrue, T., N.F. Lowndes, and R. Ceredig, Mesenchymal stromal cells: radioresistant members of the bone marrow. Immunol Cell Biol, 2013. 91(1): p. 511.

107. Aslakson, C.J. and F.R. Miller, Selective events in the metastatic process defined by analysis of the sequential dissemination of subpopulations of a mouse mammary tumor. Cancer Res, 1992. 52(6): p. 1399-405. 
108. Kaur, P., et al., A mouse model for triple-negative breast cancer tumorinitiating cells (TNBC-TICs) exhibits similar aggressive phenotype to the human disease. BMC Cancer, 2012. 12: p. 120.

109. Park, S.J., R.J. Kim, and J.S. Nam, Inhibitor of DNA-binding 4 contributes to the maintenance and expansion of cancer stem cells in 4T1 mouse mammary cancer cell line. Lab Anim Res, 2011. 27(4): p. 333-8.

110. Tian, Y.H., et al., [Radiation-induced G2 phase arrest may contribute to the radioresistance of breast cancer stem cells]. Nan Fang Yi Ke Da Xue Xue Bao, 2011. 31(1): p. 53-6.

111. Diehn, M. and M.F. Clarke, Cancer stem cells and radiotherapy: new insights into tumor radioresistance. J Natl Cancer Inst, 2006. 98(24): p. 1755-7.

112. Jacques Bernier, E.J.H.A.G., Radiation oncology: a century of achievements.

Nature Reviews Cancer, 2004. 4: p. 737-747.

113. Strem, B.M., et al., Multipotential differentiation of adipose tissue-derived stem cells. Keio J Med, 2005. 54(3): p. 132-41.

114. (ISSCR), I.S.f.S.C.R., Advancing Stem Cell Biology toward Stem Cell Therapeutics. Cell Stem Cell 2012. 10: p. 149-150.

115. Sali Al-Ansari, J.A.E.M.Z., Andrei Barasch, Jan de Lange, Fred R. Rozema, Judith E. Raber-Durlacher, Oral mucositis induced by anticancer therapies. Curr Oral Health Rep, 2015. 2: p. 202-211.

116. Karthaus, M., C. Rosenthal, and A. Ganser, Prophylaxis and treatment of chemo- and radiotherapy-induced oral mucositis - are there new strategies? Bone Marrow Transplant, 1999. 24(10): p. 1095-108. 
117. Rosenthal, C. and M. Karthaus, [Current approaches in prevention and therapy of chemo- and radiotherapy-induced oral mucositis]. Wien Med Wochenschr, 2001. 151(3-4): p. 53-65.

118. Volpato, L.E., et al., Radiation therapy and chemotherapy-induced oral mucositis. Braz J Otorhinolaryngol, 2007. 73(4): p. 562-8.

119. Sonis, S.T., Mucositis as a biological process: a new hypothesis for the development of chemotherapy-induced stomatotoxicity. Oral Oncol, 1998. 34(1): p. 39-43.

120. Feller, L., et al., Chemotherapy-and radiotherapy-induced oral mucositis: pathobiology, epidemiology and management. SADJ, 2010. 65(8): p. 372-4.

121. Judith E. Raber-Durlacher, S.E., Andrei Barasch, Oral mucositis. Oral Oncology, 2010. 46: p. 452-456.

122. Elting, L.S., et al., Risk, outcomes, and costs of radiation-induced oral mucositis among patients with head-and-neck malignancies. Int J Radiat Oncol Biol Phys, 2007. 68(4): p. 1110-20.

123. Luo, D.H., et al., [Analysis of oral mucositis risk factors during radiotherapy for nasopharyngeal carcinoma patients and establishment of a discriminant model]. Ai Zheng, 2005. 24(7): p. 850-4.

124. Chen, S.C., et al., Changes and predictors of radiation-induced oral mucositis in patients with oral cavity cancer during active treatment. Eur J Oncol Nurs, 2015.

125. Million, J.E.a.R., Prevention and management of oral mucositis in patients with cancer. Seminars in Oncology Nursing, 2007: p. 201-212. 
126. Sonis, S.T., Mucositis: The impact, biology and therapeutic opportunities of oral mucositis. Oral Oncol, 2009. 45(12): p. 1015-20.

127. Sonis ST, E.L., Keefe D, Peterson DE, Schubert M., Perspectives on cancer therapy-induced mucosal injury. Cancer, 2004. 100(9 Suppl): p. 1995-2025.

128. Sonis, S.T., The pathobiology of mucositis. Nature Review: Cancer, APRIL 2004. 4: p. 277-284.

129. Sonis, S.T., Pathobiology of Oral Mucositis: Novel Insights and Opportunities. J Support Oncol, 2004. 5: p. 3-11.

130. Redding, S.W., Cancer therapy-related oral mucositis. J Dent Educ, 2005. 69(8): p. 919-29.

131. Etiz, D., et al., Comparison of radiation-induced oral mucositis scoring systems. Tumori, 2002. 88(5): p. 379-84.

132. Sonis, S.T., et al., Validation of a new scoring system for the assessment of clinical trial research of oral mucositis induced by radiation or chemotherapy. Mucositis Study Group. Cancer, 1999. 85(10): p. 2103-13.

133. WCCNR, Assessing stomatitis: refinement of the Western Consortium for Cancer Nursing Research (WCCNR) stomatitis staging system. Can Oncol Nurs J., 1998. 4: p. 160-165.

134. Trotti A, B.R., Stetz J, et al., Common toxicity criteria: version 2.0. An improved reference for grading the acute effects of cancer treatment: impact on radiotherapy. Int J Radiat Oncol Biol Phys, 2000. 47: p. 13-47.

135. National Cancer Institute Common Toxicity Criteria. Version 2.0, J., 1999. Available at: http://ctep.info.nih.gov. Accessed January 20, 2005., 1999. 
136. McGuire DB, P.D., Muller S, et al., The 20 item oral mucositis index: reliability and validity in bone marrow and stem cell transplant patients. Cancer Invest, 2002. 20: p. 11.

137. Sonis ST, O.G., Fuchs F, et al., Oral mucositis and the clinical and economic outcomes of hematopoietic stem-cell transplantation. J Clin Oncol, 2001. 19: p. 2201-2205.

138. Parker, L., Prevention and Management of Oral Mucositis for an Outpatient Oncology Setting. The Oklahoma Nurse, 2005. July: p. 10-12.

139. Quinn, B., et al., Guidelines for the assessment of oral mucositis in adult chemotherapy, radiotherapy and haematopoietic stem cell transplant patients. Eur J Cancer, 2008. 44(1): p. 61-72.

140. Schmidt, W., et al., A proteomic evaluation of the effects of the pharmaceuticals diclofenac and gemfibrozil on marine mussels (Mytilus spp.): evidence for chronic sublethal effects on stress-response proteins. Drug Test Anal, 2014. 6(3): p. 210-9.

141. M. Schmidt, J.H., R. Noack, A. Siegemund, P. Gabriel, W. Dörr, Effects of bone marrow or mesenchymal stem cell transplantation on oral mucositis (mouse) induced by fractionated irradiation. Strahlenther Onkol 2013. 4(190): p. 399-404.

142. Spitkovsky, D. and J. Hescheler, Adult mesenchymal stromal stem cells for therapeutic applications. Minim Invasive Ther Allied Technol, 2008. 17(2): p. 79-90. 
143. Mouiseddine, M., et al., Human mesenchymal stem cells home specifically to radiation-injured tissues in a non-obese diabetes/severe combined immunodeficiency mouse model. Br J Radiol, 2007. 80 Spec No 1: p. S49-55.

144. Yi, T. and S.U. Song, Immunomodulatory properties of mesenchymal stem cells and their therapeutic applications. Arch Pharm Res, 2012. 35(2): p. 21321.

145. Shi, M., Z.W. Liu, and F.S. Wang, Immunomodulatory properties and therapeutic application of mesenchymal stem cells. Clin Exp Immunol, 2011. 164(1): p. 1-8.

146. Marigo, I. and F. Dazzi, The immunomodulatory properties of mesenchymal stem cells. Semin Immunopathol, 2011. 33(6): p. 593-602.

147. Moura, J.F., et al., A novel model of megavoltage radiation-induced oral mucositis in hamsters: Role of inflammatory cytokines and nitric oxide. Int $\mathrm{J}$ Radiat Biol, 2015. 91(6): p. 500-9.

148. Wang, H., et al., HGF Gene Modification in Mesenchymal Stem Cells Reduces Radiation-Induced Intestinal Injury by Modulating Immunity. PLoS One, 2015. 10(5): p. e0124420.

149. Zhang, J., et al., Hepatocyte growth factor gene-modified adipose-derived mesenchymal stem cells ameliorate radiation induced liver damage in a rat model. PLoS One, 2014. 9(12): p. e114670.

150. Xue, J., et al., Gene-modified mesenchymal stem cells protect against radiation-induced lung injury. Mol Ther, 2013. 21(2): p. 456-65. 
151. Layla T. Galindo, T.R.M.F., Patricia Semedo, Carolina B. Ariza, CarolineM.Moreira, Niels O. S. Camara, andMarimelia A. Porcionatto, Mesenchymal Stem Cell TherapyModulates the Inflammatory Response in Experimental Traumatic Brain Injury. Neurology Research International, 2011. 2011: p. 1-9, Article ID 564089.

152. Mathur, A. and J.F. Martin, Stem cells and repair of the heart. Lancet, 2004. 364(9429): p. 183-92.

153. Orlic, D., et al., Mobilized bone marrow cells repair the infarcted heart, improving function and survival. Proc Natl Acad Sci U S A, 2001. 98(18): p. 10344-9.

154. Ezquer, F.E., et al., Systemic administration of multipotent mesenchymal stromal cells reverts hyperglycemia and prevents nephropathy in type 1 diabetic mice. Biol Blood Marrow Transplant, 2008. 14(6): p. 631-40.

155. Kotenko, K.B., et al., [Mesenchymal stem cells transplantation in the treatment of radiation skin lesions]. Patol Fiziol Eksp Ter, 2011(1): p. 20-5.

156. Jeong, J.H., Adipose stem cells and skin repair. Curr Stem Cell Res Ther, 2010. 5(2): p. 137-40.

157. Arthur, A., A. Zannettino, and S. Gronthos, The therapeutic applications of multipotential mesenchymal/stromal stem cells in skeletal tissue repair. J Cell Physiol, 2009. 218(2): p. 237-45.

158. Kudo, K., et al., Transplantation of mesenchymal stem cells to prevent radiation-induced intestinal injury in mice. J Radiat Res, 2010. 51(1): p. 73-9. 
159. Maria, O.M., et al., Adipose mesenchymal stromal cells response to ionizing radiation. Cytotherapy, 2016. 18: p. 384-401.

160. Silvana B. De Lorenzo1, A.G.P., Rachel M. Hurley and Scott H. Kaufmann1,, The elephant and the blind men: making sense of PARP inhibitors in homologous recombination deficient tumor cells. FrontiersinOncology | CancerMolecularTargetsandTherapeutics, 2013. 3: p. 1-, Article 228.

161. Zhang, J., et al., Effects of transplanted bone marrow mesenchymal stem cells on the irradiated intestine of mice. J Biomed Sci, 2008. 15(5): p. 585-94.

162. Bessout, R., et al., Mesenchymal stem cell therapy induces glucocorticoid synthesis in colonic mucosa and suppresses radiation-activated T cells: new insights into MSC immunomodulation. Mucosal Immunol, 2014. 7(3): p. 65669.

163. Chen, H., et al., Pre-activation of mesenchymal stem cells with TNF-alpha, IL1 beta and nitric oxide enhances its paracrine effects on radiation-induced intestinal injury. Sci Rep, 2015. 5: p. 8718.

164. Kursova, L.V., et al., Possibilities for the use of autologous mesenchymal stem cells in the therapy of radiation-induced lung injuries. Bull Exp Biol Med, 2009. 147(4): p. 542-6.

165. Wang, R., et al., Experimental treatment of radiation pneumonitis with human umbilical cord mesenchymal stem cells. Asian Pac J Trop Med, 2014. 7(4): p. 262-6.

166. Zhang, J., et al., Adipose-derived Mesenchymal Stem Cells (ADSCs) with the Potential to Ameliorate Platelet Recovery, Enhance Megakaryopoiesis and 
Inhibit Apoptosis of Bone Marrow Cells in a Mouse Model of RadiationInduced Thrombocytopenia. Cell Transplant, 2015.

167. Drouet, M., et al., Mesenchymal stem cells rescue CD34+ cells from radiation-induced apoptosis and sustain hematopoietic reconstitution after coculture and cografting in lethally irradiated baboons: is autologous stem cell therapy in nuclear accident settings hype or reality? Bone Marrow Transplant, 2005. 35(12): p. 1201-9.

168. Gan, J., et al., Hematopoietic recovery of acute radiation syndrome by human superoxide dismutase-expressing umbilical cord mesenchymal stromal cells. Cytotherapy, 2015. 17(4): p. 403-17.

169. Kursova, L.V., et al., Allogenic cardiomyoblasts raised from human mesenchymal stem cells in the therapy of radiation cardiomyopathy and pericarditis: case report. Bull Exp Biol Med, 2014. 157(1): p. 143-5.

170. Francois, S., et al., Human mesenchymal stem cells provide protection against radiation-induced liver injury by antioxidative process, vasculature protection, hepatocyte differentiation, and trophic effects. Biomed Res Int, 2013. 2013: p. 151679.

171. Chen, Y.X., et al., Mesenchymal stem cell-conditioned medium prevents radiation-induced liver injury by inhibiting inflammation and protecting sinusoidal endothelial cells. J Radiat Res, 2015.

172. Voswinkel, J., et al., Gastro-intestinal autoimmunity: preclinical experiences and successful therapy of fistulizing bowel diseases and gut Graft versus host 
disease by mesenchymal stromal cells. Immunol Res, 2013. 56(2-3): p. 241 8.

173. Locke, M., J. Windsor, and P.R. Dunbar, Human adipose-derived stem cells: isolation, characterization and applications in surgery. ANZ J Surg, 2009. 79(4): p. 235-44.

174. Sugii, S., et al., Human and mouse adipose-derived cells support feederindependent induction of pluripotent stem cells. Proc Natl Acad Sci U S A, 2010. 107(8): p. 3558-63.

175. Yamamoto, N., et al., Isolation of multipotent stem cells from mouse adipose tissue. J Dermatol Sci, 2007. 48(1): p. 43-52.

176. Taha, M.F. and V. Hedayati, Isolation, identification and multipotential differentiation of mouse adipose tissue-derived stem cells. Tissue Cell, 2010. 42(4): p. 211-6.

177. Heravi, M., et al., Sorafenib in combination with ionizing radiation has a greater anti-tumour activity in a breast cancer model. Anticancer Drugs, 2012. 23(5): p. 525-33.

178. Heravi, M., et al., Interaction of ionizing radiation and ZRBA1, a mixed EGFR/DNA-targeting molecule. Anticancer Drugs, 2009. 20(8): p. 659-67.

179. Heravi, M., et al., ZRBA1, a Mixed EGFR/DNA Targeting Molecule, Potentiates Radiation Response Through Delayed DNA Damage Repair Process in a Triple Negative Breast Cancer Model. Int J Radiat Oncol Biol Phys, 2015. 92(2): p. 399-406. 
180. Huang, X. and Z. Darzynkiewicz, Cytometric assessment of histone H2AX phosphorylation: a reporter of DNA damage. Methods Mol Biol, 2006. 314: $\mathrm{p}$. 73-80.

181. Olive, P.L. and J.P. Banath, The comet assay: a method to measure DNA damage in individual cells. Nat Protoc, 2006. 1(1): p. 23-9.

182. Britton, K.M., et al., Cancer stem cells and side population cells in breast cancer and metastasis. Cancers (Basel), 2011. 3(2): p. 2106-30.

183. Nguyen, N.P., et al., Molecular biology of breast cancer stem cells: potential clinical applications. Cancer Treat Rev, 2010. 36(6): p. 485-91.

184. D'Andrea, F.P., et al., Tumourigenicity and radiation resistance of mesenchymal stem cells. Acta Oncol, 2012. 51(5): p. 669-79.

185. Maugeri-Sacca, M., M. Bartucci, and R. De Maria, DNA damage repair pathways in cancer stem cells. Mol Cancer Ther, 2012. 11(8): p. 1627-36.

186. Doostzadeh-Cizeron, J., N.H. Terry, and D.W. Goodrich, The nuclear death domain protein p84N5 activates a G2/M cell cycle checkpoint prior to the onset of apoptosis. J Biol Chem, 2001. 276(2): p. 1127-32.

187. Doostzadeh-Cizeron, J., S. Yin, and D.W. Goodrich, Apoptosis induced by the nuclear death domain protein p84N5 is associated with caspase-6 and NFkappa B activation. J Biol Chem, 2000. 275(33): p. 25336-41.

188. Hall, E.J.G., Amato J, Radiobiology for the Radiologist, 6th Edition. 2006: Lippincott Williams \& Wilkins. 
189. Sugrue, T., et al., Multiple facets of the DNA damage response contribute to the radioresistance of mouse mesenchymal stromal cell lines. Stem Cells, 2013. 31(1): p. 137-45.

190. Singh, S., et al., Mesenchymal stem cells show radioresistance in vivo. J Cell Mol Med, 2012. 16(4): p. 877-87.

191. Zheng, C., et al., Prevention of radiation-induced oral mucositis after adenoviral vector-mediated transfer of the keratinocyte growth factor cDNA to mouse submandibular glands. Clin Cancer Res, 2009. 15(14): p. 4641-8.

192. Gomez-Casal, R., et al., Non-small cell lung cancer cells survived ionizing radiation treatment display cancer stem cell and epithelial-mesenchymal transition phenotypes. Mol Cancer, 2013. 12(1): p. 94.

193. D'Andrea, F.P., Intrinsic radiation resistance of mesenchymal cancer stem cells and implications for treatment response in a murine sarcoma model. Dan Med J, 2012. 59(2): p. B4388.

194. Gruber, S., et al., Modulation of radiation-induced oral mucositis by pentoxifylline: preclinical studies. Strahlenther Onkol, 2015. 191(3): p. 242-7.

195. Soleymaninejadian, E., K. Pramanik, and E. Samadian, Immunomodulatory properties of mesenchymal stem cells: cytokines and factors. Am J Reprod Immunol, 2012. 67(1): p. 1-8.

196. Ivanova-Todorova, E., et al., Conditioned medium from adipose tissuederived mesenchymal stem cells induces CD4+FOXP3+ cells and increases IL-10 secretion. J Biomed Biotechnol, 2012. 2012: p. 295167. 
197. Djojosubroto, M., et al., Chromosomal number aberrations and transformation in adult mouse retinal stem cells in vitro. Invest Ophthalmol Vis Sci, 2009. 50(12): p. 5975-87.

198. Bonner, A.E., Y. Wang, and M. You, Gene expression profiling of mouse teratocarcinomas uncovers epigenetic changes associated with the transformation of mouse embryonic stem cells. Neoplasia, 2004. 6(5): p. 490502.

199. Bucchini, D., et al., Stable transformation of mouse teratocarcinoma stem cells with the dominant selective marker Eco.gpt and retention of their developmental potentialities. EMBO J, 1983. 2(2): p. 229-32.

200. Dominina, A.P., et al., [Mesenchymal stem cells of human endometrium do not undergo spontaneous transformation during long-term cultivation]. Tsitologiia, 2013. 55(1): p. 69-74.

201. Ren, Z., Y.A. Zhang, and Z. Chen, Spontaneous transformation of cynomolgus mesenchymal stem cells in vitro: further confirmation by short tandem repeat analysis. Exp Cell Res, 2012. 318(5): p. 435-40.

202. Torsvik, A., et al., Spontaneous malignant transformation of human mesenchymal stem cells reflects cross-contamination: putting the research field on track - letter. Cancer Res, 2010. 70(15): p. 6393-6.

203. Gou, S., et al., Spontaneous differentiation of murine bone marrow-derived mesenchymal stem cells into adipocytes without malignant transformation after long-term culture. Cells Tissues Organs, 2010. 191(3): p. 185-92. 
204. Garcia, S., et al., Pitfalls in spontaneous in vitro transformation of human mesenchymal stem cells. Exp Cell Res, 2010. 316(9): p. 1648-50.

205. Rosland, G.V., et al., Long-term cultures of bone marrow-derived human mesenchymal stem cells frequently undergo spontaneous malignant transformation. Cancer Res, 2009. 69(13): p. 5331-9.

206. Popov, B.V., et al., [Spontaneous transformation and immortalization of mesenchymal stem cells in vitro]. Tsitologiia, 2009. 51(2): p. 91-102.

207. Ruan, Z.B., et al., Karyotype stability of human umbilical cord-derived mesenchymal stem cells during culture. Exp Ther Med, 2014. 8(5): p. 15081512.

208. Bellotti, C., et al., Analysis of the karyotype of expanded human adiposederived stem cells for bone reconstruction of the maxillo-facial region. Int $\mathrm{J}$ Immunopathol Pharmacol, 2013. 26(1 Suppl): p. 3-9.

209. Poloni, A., et al., Human mesenchymal stem cells from chorionic villi and amniotic fluid are not susceptible to transformation after extensive in vitro expansion. Cell Transplant, 2011. 20(5): p. 643-54.

210. Thomson, A., et al., Human embryonic stem cells passaged using enzymatic methods retain a normal karyotype and express CD30. Cloning Stem Cells, 2008. 10(1): p. 89-106.

211. Zhang, W.H., et al., [Cultivation and karyotype analysis of the human embryonic stem cells HUES4]. Zhonghua Yi Xue Yi Chuan Xue Za Zhi, 2007. 24(3): p. 275-8. 
212. Prokhorovich, M.A., et al., Cultures of hESM human embryonic stem cells: chromosomal aberrations and karyotype stability. Bull Exp Biol Med, 2007. 144(1): p. 126-9. 